\title{
Restoration Guidelines for Wetlands of the Western Prairie Pothole Region
}

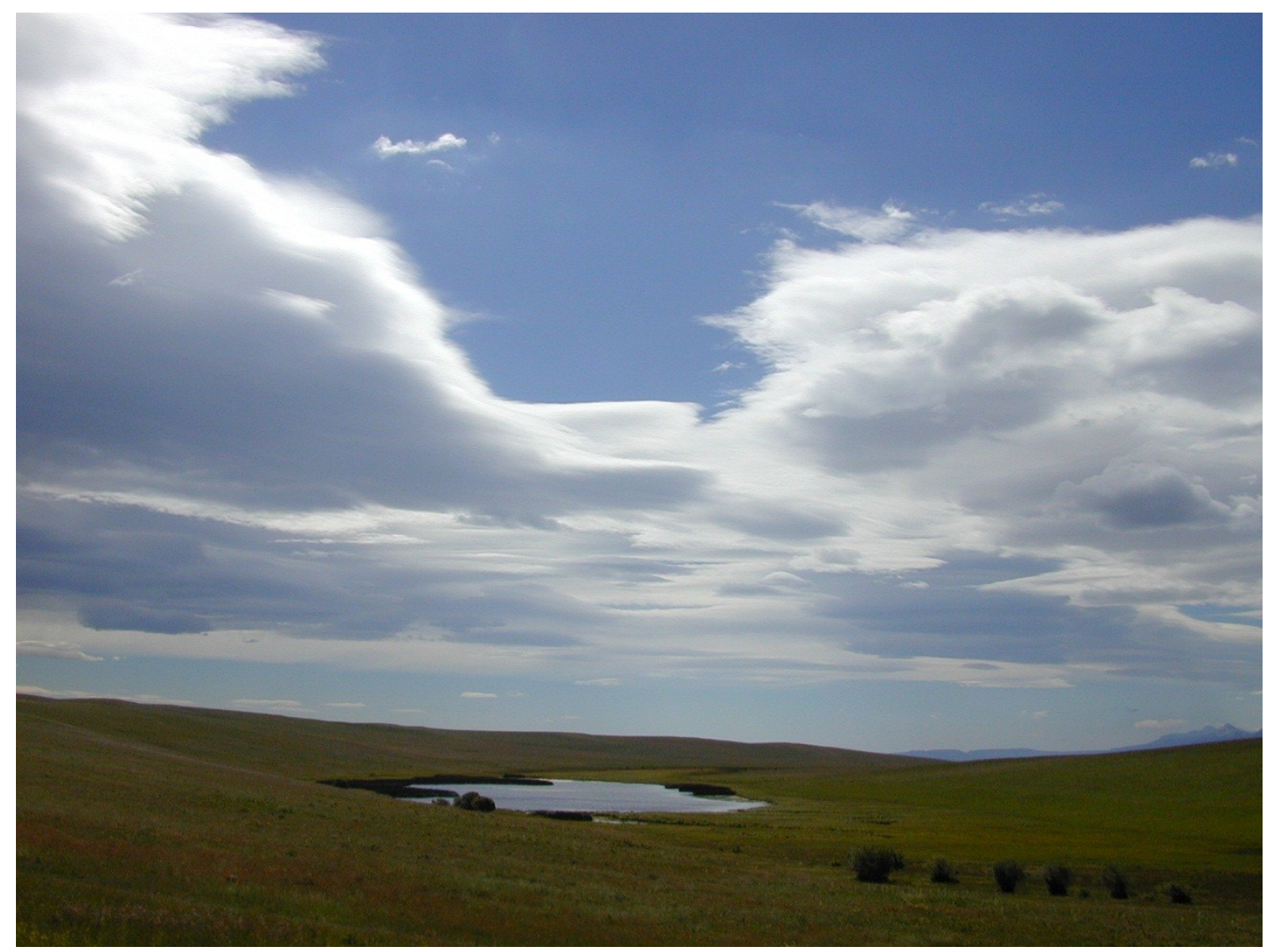

Prepared for the US Environmental Protection Agency

by

Tara Luna, Linda Vance and Melissa Hart

November 2012

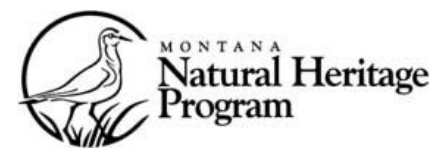

A program of the Montana State Library's Natural Resource Information System operated by the University of Montana 


\section{Restoration Guidelines for Wetlands of the Western Prairie Pothole Region}

Prepared for:

The U.S. Environmental Protection Agency

Agreement Number: CD97847601

Prepared by:

Tara Luna, Linda Vance and Melissa Hart
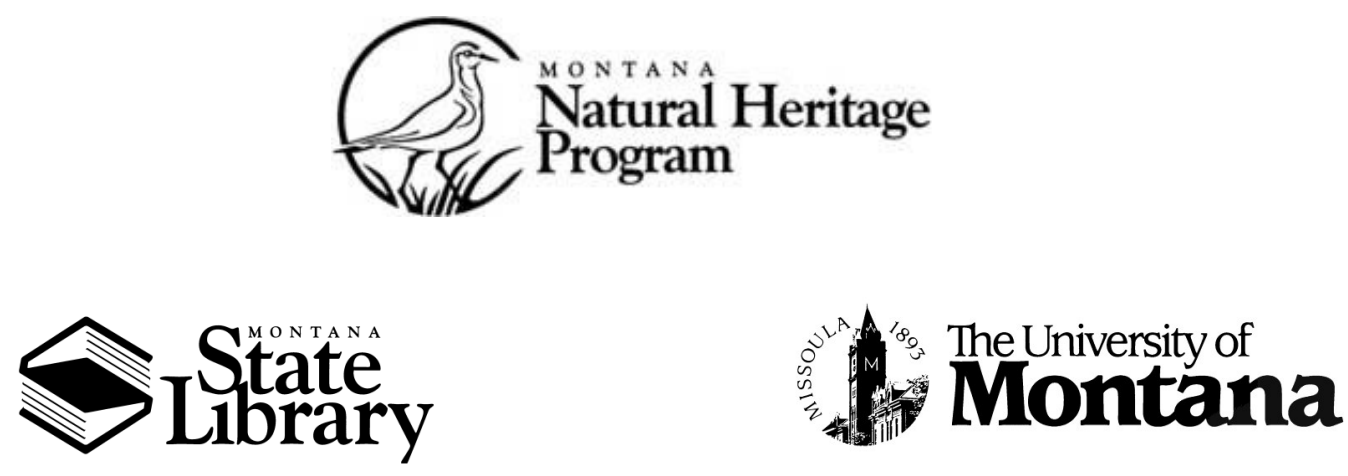

P.O. Box $201800 \cdot 1515$ East Sixth Avenuëi · Helena, Montana 59620-1800 • (406) 444-5354 
This document should be cited as follows:

Luna, T., L. Vance and M. Hart. 2012. Restoration Guidelines for Wetlands of the Western

Prairie Pothole Region. Report to the U.S. Environmental Protection Agency. Montana Natural Heritage Program, Helena, MT. 123 pp. plus appendices. 


\section{Executive Summary}

Wetlands of the Western Prairie Pothole Region (PPR) in Montana, Alberta and Saskatchewan, are widely recognized for their significance as critical breeding habitat for waterfowl. As threats to these important wetlands have multiplied, resource managers, landowners and conservation practitioners have increasingly turned to restoration as a way of offsetting losses and restoring wetland function and biodiversity. Because of the ecological complexity of wetlands in the prairie matrix, restoration efforts require a thorough understanding and application of ecological principals and processes, as well as an understanding of environmental and ecological parameters. These guidelines, which grew from our work assessing wetlands in the Milk, Marias, and St. Mary's river basins, are presented as an introduction to the factors involved in undertaking wetland restoration in the region.

Chapter 1 describes the wetland ecological systems and characteristic plant associations found in the Western Prairie Pothole Region of Montana. It explains how dynamic annual and seasonal changes of hydroperiod, water depth, and water chemistry directly influence the composition, diversity, and spatial distribution of plant communities within wetlands, and how both hydrologic alteration and drought can affect community composition. It also discusses how seed banks and persistent rhizomes and root systems, soils, and presence of organic matter also affect the spatial distribution, diversity, and composition of the major plant associations within a wetland ecological system.

Chapter 2 focuses on the importance of understanding environmental stressors when planning a wetland restoration. The types and intensity of stressors are major factors in determining wetland health and condition, and the ability to eliminate stressors or mute their impact is a determinant in evaluating a site's suitability for restoration and the degree of recovery that can realistically be expected there over time. All of a wetland system's ecological processes and environmental and biological influences must be thoroughly assessed when considering restoration efforts, as each factor will help formulate rational and ecologically sound restoration goals and objectives for chosen sites.

Chapter 3 discusses criteria for evaluating a wetland's suitability for restoration, emphasizing its relation to other wetlands, its landscape context, minimally disturbed soils and hydrology, and the presence of native vegetation in the wetland and surrounding upland. It also emphasizes the need to assess all potential restoration wetlands, using well-tested methods. In this chapter, we describe a three-tiered assessment approach used by the Montana Natural Heritage Program (MTNHP): a coarse scale GIS analysis, a rapid field assessment based on ecological indicators and a stressor checklist, and an intensive assessment emphasizing vegetation composition. Taken together, results from all three levels of wetland assessment can be reviewed to prioritize wetlands for restoration and management.

Chapter 4 lays out the tools and techniques needed for planning an effective restoration project, including ecological reference sites. It offers suggestions on defining restoration project objectives, drafting the restoration plan, and identifying limiting factors that must be addressed to ensure a successful project.

Chapter 5 introduces the challenges associated with restoring or remediating hydrology, including water sources, inundation periods, outflows, and drawdowns. It stresses the need to understand wetland hydrology at multiple scales, 
and carrying out thorough investigations of hydrologic stressors and alterations both at the site and in adjacent uplands. It provides specific advice on ditch plugging and actions to reduce sedimentation and erosion.

Chapter 6 follows with an examination of hydric soils, and techniques for describing soil color, texture and structure, including evidence of compaction. We emphasize soil surface stability, and the factors that contribute to it, notably soil texture, slope length, slope gradient, soil type, flooding events or water input, and existing topsoil cover. Specific methods for improving soil surface stability, and balancing organic matter accumulation, are discussed in detail.

Chapter 7 offers a detailed set of guidelines for the collection of seeds and cuttings for revegetation. We cover the steps required to obtain an adequate quantity and quality of genetically adapted seeds and cuttings to meet the goal of reestablishing selfsustaining plant populations. As part of these guidelines, we discuss how wetland and riparian species exhibit unique characteristics in their reproductive strategies, morphology, and ecology, and the importance of taking these characteristics into count in collection. We also give detailed instructions for handling and storage.

Chapter 8 covers the selection, care and planting of nursery stock, including identification of outplanting windows, stock types for herbaceous and woody species, ways to harden, condition and store nursery stock, planting densities and patterns, and post-planting care. We also discuss plant salvage at impacted sites, and agricultural wetland conservation plantings.

Chapter 9 concludes with a suite of guidelines for developing and implementing a restoration monitoring plan. It covers twelve components of a comprehensive monitoring plan, including considerations of budget and timing, the selection of performance indicators, identification of testable hypotheses, the QA/QC plan, and information sharing. We discuss how existing assessment protocols can be adapted to meet specific monitoring needs, and stress that restoration monitoring has to cover landscape context, hydrology and soils as well as vegetation. For projects that are too small or have too limited a budget to do full-scale quantitative monitoring, we describe the use of photo points for quantitative monitoring. 


\section{Acknowledgements}

This project was funded by a Wetland Program Development Grant from Region 8 of the U.S. Environmental Protection Agency. We would like to thank Toney Ott, and Jill Minter for their support and help in building our wetland program over the years. We also thank Lynda Saul of the Montana Department of Environmental Quality for her encouragement and assistance, and for being such a dedicated advocate for wetlands.

Many people reviewed early drafts of this report, and offered suggestions that greatly improved the final product: Mary Manning and Steve Shelly of the United States Forest Service; Wendy Velman of the Bureau of Land Management; Mary Clare Weatherwax of the Blackfeet Nation Environmental Office; Keith Gopher of the Rocky Boys' Chippewa Cree Tribal Environmental Program; Jeanne Spaur of the Fort Peck Assiniboine and Sioux Tribe's Wetland
Program; and Tom Hinz and Jim Hansen of Montana Fish Wildlife and Parks. We also thank Tom Landis, Alex Gladstone, Dave Steinfeld, Joe Scianna, Derek Tilley and Chris Hoag for their permission to use their photographs and illustrations. All other photographs were taken by the authors or other MTNHP staff

Finally, we thank Karen Newlon, Cat McIntyre, Nick Smith, Karissa Ramstead, Sara Owen, Eva Masin, Natalie Byars, Marilyn Hirsch, Jessica Clarke and Sam Isham for the many hours they have put in field testing the MTNHP's wetland assessment protocol, and for enhancing our understanding of wetland dynamics through their observations and insights.

If we have overlooked anyone, we sincerely apologize for the oversight. Those omissions, and any other omission and errors in the work are the responsibility of the authors ${ }^{1}$ alone.

1. Tara Luna left the Montana Natural Heritage Program after several years' dedicated work as our restoration ecologist. Any questions about this document should be addressed to Linda Vance. 


\section{Table of Contents}

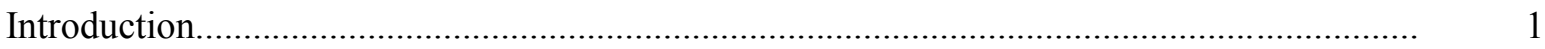

Chapter 1: Wetland Ecological Systems and Vegetation Community Dynamics...................... 3

Ecological Systems and Plant Associations............................................................ 3

Ecological System Descriptions.......................................................................... 4

Wetland Plant Community Dynamics..................................... 26

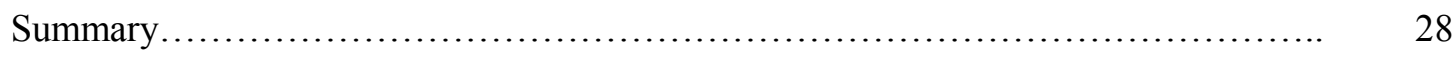

Chapter 2: The Role of Stressors in Ecological Restoration................................................. 30

Stressors in the Western Prairie Pothole Region........................................................ $\quad 30$

Applying Ecological Principles to Restoration Planning Efforts................... 34

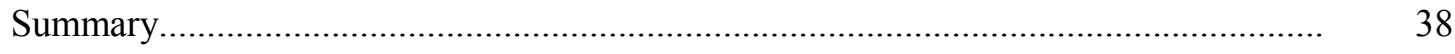

Chapter 3: Assessing Restoration Suitability .................................. 39

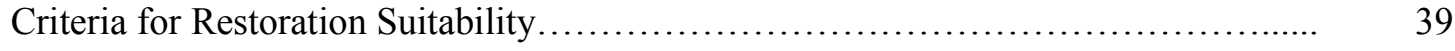

Tools for Assessing Sites and Restorations Areas.............................. 41

The Three-Tier Approach to Assessing Wetland Function and Integrity......................... 41

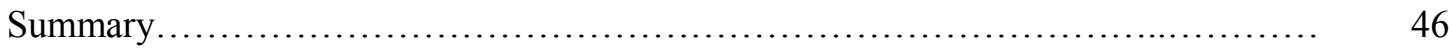

Chapter 4: Restoration Project Planning ....................................... 48

Ecological Reference Sites............................................ 48

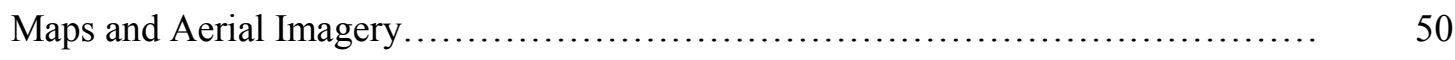

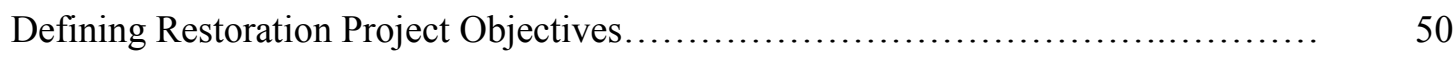

Developing the Restoration Plan.......................................................................... 51

Identifying the Limiting Factors of the Project Site ........................... 52

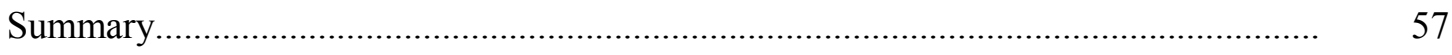

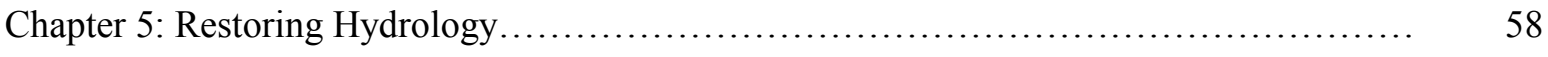

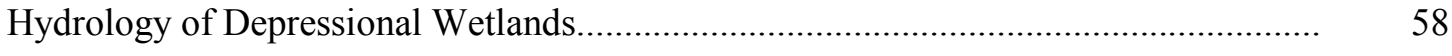




\section{Table of Contents (Continued)}

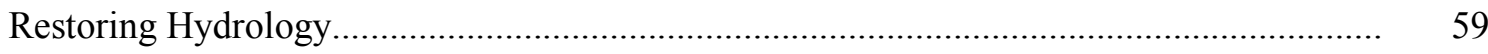

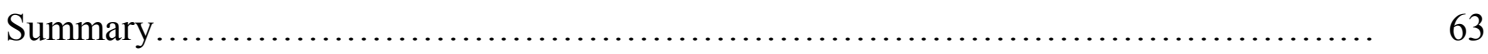

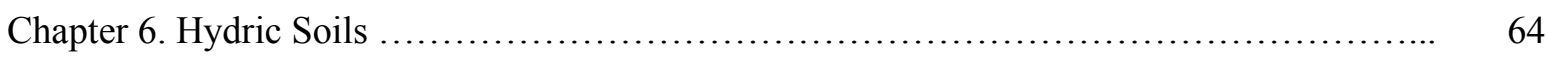



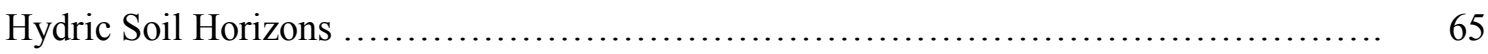

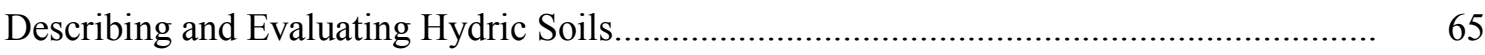

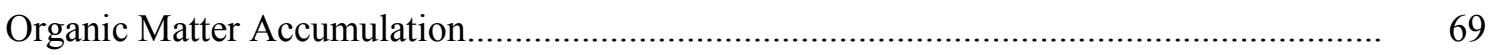

Methods for Mitigating Soil Compaction in Wetlands................................................. 70

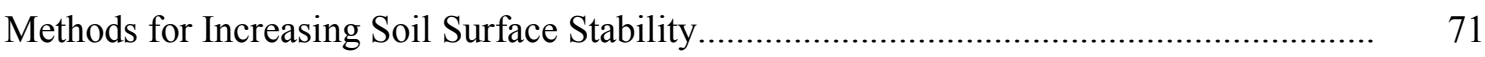

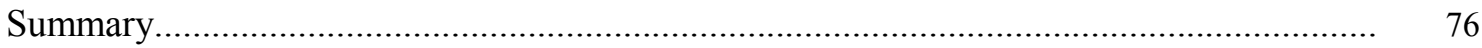

Chapter 7: Collecting Seeds and Cuttings for Revegetation............................ 77

Using Genetically Adapted Seed Sources...................................... 77

Applying Plant Ecology Principles to Seed Collection Efforts......................... 78

Performing a Cutting Test Prior to Seed Collection............................... 81

Temporary Storage and Handling of Seed Collections............................... 81

Considerations When Using Commercial Seed Sources............................ 83

Using Vegetative Propagule Sources......................................... 84

Collecting Other Vegetative Propagules for Restoration Purposes..................... 91

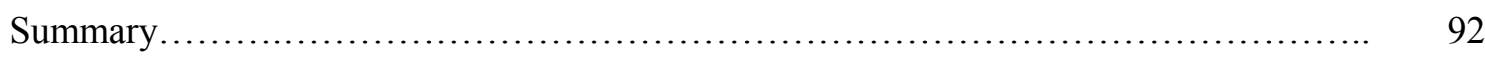

Chapter 8: Stock Selection and Site Planting.................................... 94

The Outplanting Window in Wetland and Riparian Restoration Sites................... 94

Planning and Scheduling the Nursery Stock for Outplanting Windows................. 94

Stock Types for Herbaceous Species.......................................... 95

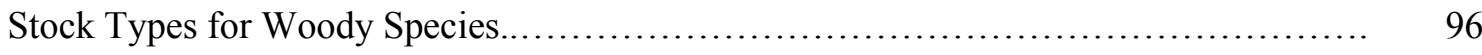

Physiologically Hardened and Conditioned Nursery Stock........................ 97

Transport, Care and Temporary Storage of Nursery Stock during Outplanting................ 98 


\section{Table of Contents (Continued)}

Plant Salvage........................................................... 102

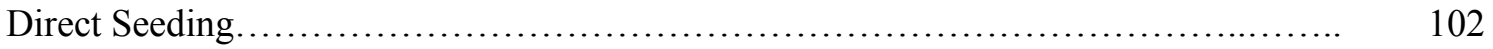

Agricultural Wetland Conservation Plantings................................... 104

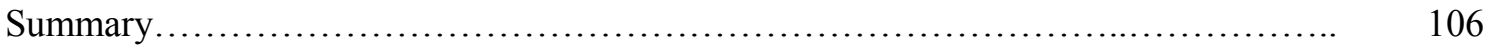

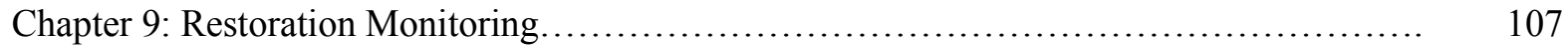

Developing a Monitoring Plan........................................... 107

Tailoring Monitoring Protocols to Specific Needs...................................................... 110

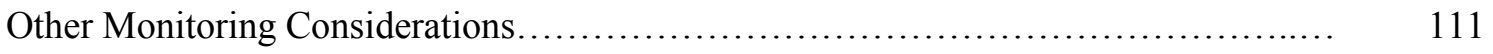

Using Photo Points for Qualitative Monitoring ......................................................... 112

Summary............................................................ 112

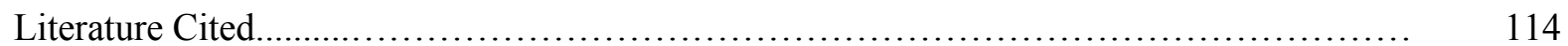

Appendix A. Glossary of terms

Appendix B. Plant associations and alliances found in Western Prairie Pothole Region wetland ecological systems

Appendix C. Scoring procedure for calculating stressor impact

Appendix D. Terminology, description, and calculation of the floristic quality assessment metrics. 


\section{Introduction}

The Northwestern Glaciated Plains ecoregion of Montana, which extends into adjacent southern Alberta and Saskatchewan, has a great diversity and abundance of wetland habitats, including prairie potholes, open and closed depressional wetlands, saline depressions, and emergent marshes. These wetlands, particularly the prairie potholes, are widely recognized for their significance as critical breeding habitat for waterfowl. Across the broad prairie pothole region, production estimates for waterfowl range from $50 \%$ to $80 \%$ of the North America's main species (Batt et al. 1989). With their surrounding grasslands, these wetlands support rich assemblages of water-dependent and upland birds, amphibians, and mammals, including many Species of Concern (Hendricks et al. 2007; McIntyre et al. 2011).

Although wetlands in the semi-arid Glaciated Plains (also known as the western Prairie Pothole Region, or PPR) are uniquely important biological refugia, they face multiple threats: direct loss due to agricultural conversion, hydrologic modification, energy development and climate change (Gleason et al. 2011); fragmentation and loss of hydrologic connectivity caused by roads and agricultural drainage (Leibowitz and Vining 2003); and degradation of surface and groundwater quality from oil drilling (Preston 2011). At the same time, increasing land costs have hampered the U.S. Fish and Wildlife Service's efforts to acquire land for habitat protection. According to a 2007 Government Accountability Office report, at the current rate of acquisition, it will take the Service almost 150 years to acquire the amount of wetland and associated grassland acres that are required to sustain existing migratory bird populations in the PPR (GAO 2007).
As threats to these important wetlands have multiplied, resource managers, landowners and conservation practitioners have increasingly turned to restoration as a way of offsetting losses and restoring wetland function and biodiversity. Because of the ecological complexity of wetlands in the prairie matrix, restoration efforts require a thorough understanding and application of ecological principals and processes, as well as an understanding of environmental and ecological parameters. The task of restoring a wetland requires that the restoration planner evaluate numerous environmental and biological factors and stressors that characterize a particular wetland. These parameters will form the basis for ecologically appropriate restoration and land management actions that will facilitate natural ecological recovery. For example, wetlands in the Northwestern Great Plains recover more slowly than in other regions, and depressional wetlands recover more slowly compared to wetlands with riverine connectivity (Moreno-Mateos et al 2012). Too often, inappropriate restoration practices lengthen the recovery of wetland hydroperiod even more (van der Kamp et al. 1999). Restoration of hydrologic processes within wetlands requires a solid understanding of the influence of surrounding vegetation cover composition and structure, and knowledge of land management practices that occur in uplands surrounding wetlands (Gleason et al. 2011). It also requires an understanding of the importance of native vegetation. While exotic grasses may appear to meet waterfowl-specific nesting objectives, the use of non- cultivars or "improved native strains" can result in pollution of local gene pools or establishment of aggressive ecotypes that can displace natural populations. 
In the following chapters, we address wetland and riparian restoration in the Northwestern Glaciated Plains using an integrated perspective. We stress the importance of assessing and describing wetlands in terms of region-specific climate, topography, hydrologic dynamics, plant communities, aquatic life, and stressors. We also emphasize the significance of landscape position and biogeographic location, which directly influence wetland's biological communities. Finally, we urge restoration planners to adopt a landscape level view of wetland integrity. The relative density of wetlands in an area, the distance between them, their overall condition, and stressors in the larger landscape influence all influence species recruitment and long-term biodiversity of restored wetlands. Conservation and restoration efforts involving whole wetland complexes and linked isolated sites will provide an integrated, costefficient approach to maintaining ecosystem function and biological diversity. In most cases, implementing appropriate project design and land management practices will create conditions that will allow these systems to recover diversity and integrity over time, with minimal human manipulation of the sites.

We believe that restoration planners can build on a foundation of ecological knowledge and an integrated perspective to promote the natural processes that facilitate recovery, and in so doing avoid costly or counterproductive mistakes. We hope that these guidelines will support widespread efforts to conserve and effectively restore wetlands in the Northwestern Glaciated Plains. 


\section{Chapter 1: Wetland Ecological Systems and Vegetation Community Dynamics}

Wetland restoration planning requires an understanding of the function, structure, and plant community dynamics of wetlands within a given region. This knowledge allows the restoration planner to carefully consider all factors that ultimately influence natural recovery and biodiversity, incorporating these factors into a restoration plan.

Classification systems represent attempts to group wetlands by differences due to geology, hydrology, and climate, or by particular desired habitat types. One of the most familiar classification schemes is the Cowardin classification, which is the mapping legend used in the National Wetlands Inventory (Cowardin et al. 1979). The Hydrogeomorphic (HGM) classification system (Brinson 1993) is often used to define a reference ideal for wetlands in specific regions. The National Vegetation Classification Standard (NVC), which applies to both terrestrial and wetland habitats, is a hierarchical classification of vegetation groupings from the largest scale (biomes) to the smallest (plant associations). The Ecological Systems classification (Comer et al. 2003), which also extends to both upland and wetlands systems, is used as the map legend for Montana's Land Cover spatial data layer. The Ecological Systems classification, while not a part of the NVC, can be crosswalked to the NVC's macrogroup and group level, and incorporates plant associations, the NVC's finer-scale classification. In these guidelines, we classify and describe wetlands using the Ecological Systems and associations. Because they are mappable, easily recognized in the field, and generally fairly persistent over time, ecological systems are suitable organizing units for a range of restoration and management goals.

Ecological systems represent groupings of species that often co-occur under similar environmental conditions such as regional climate, landscape position, soils, hydrology, and topography. Each of these systems has characteristic plant associations, although the occurrence of a specific association in a particular wetland ecological system will depend on site specific dynamics. In this chapter, we will describe the ecological systems and common plant associations found in the Western Prairie Pothole Region, and then describe the dynamics that drive differences in their expression.

\section{Ecological systems and plant associations}

Ecological systems can be thought of as possible expression of suites of species and landforms that are favored by a set of broad environmental parameters. Within ecological systems, characteristic plant associations will often be found together when specific environmental and biological conditions support their growth and reproduction.

Vegetation associations are usually dominated by one or two (rarely three) species comprising the majority of vegetation cover. Some associations are very simple in terms of species diversity of minor components, while others may include many species in addition to the dominant ones. Plant associations also indicate the disturbance regimes at a particular site. A relatively undisturbed, extremely rich fen ecological system, for example, supports a moderately to highly complex mosaic of plant associations, while a closed depressional wetland ecological system that has been subjected to heavy disturbance may only support 
one or two associations. Vegetation of a given ecological system can be described, mapped, and delineated into distinct plant associations that indicate the variability of hydrology, soils, organic matter accumulation, and other factors found across the system. The range of plant associations described within these ecological systems can be found in Appendix B.

\section{Ecological System Descriptions}

Five herbaceous wetland ecological systems are typical in the northern Great Plains region of Montana: Great Plains Prairie Potholes; Western Great Plains Open Depression, Western Great Plains Closed Depression, Western Great Plains Saline Depression, North American Arid West Emergent Marsh, and (MTNHP 2010). Rocky Mountain Subalpine Montane Fens occur along the western edge of the Great Plains near the Rocky Mountain Front and very rarely within the northern Great Plains region. Three woody-dominated ecological systems occur within the region: Greasewood Flats, Northwestern Great Plains Riparian Woodlands and Shrublands, and Northwestern Great Plains Floodplain.

\section{Great Plains Prairie Pothole}

Prairie potholes are found across the northern glaciated Great Plains of Montana. Potholes occur in shallow, glaciated depressions. The region is distinguished by a thin mantle of glacial drift underlying stratified sedimentary material; these form a glacial landscape of end moraines, stagnation moraines, outwash plains and lake plains. The glacial drift ranges from steep to slight local relief with fine-grained, silty to clayey soils. Limestone, sandstone, and shales are the predominant parent materials, and highly mineralized water can discharge from these rocks. The prairie pothole ecological system generally occurs in a closed basin that receives irregular inputs of water from the surroundings and exports water as groundwater (Figure 1.1). The hydrology of this system is complex, and the concentration of dissolved solids results in water that ranges from fresh to extremely saline, with chemical characteristics varying seasonally and annually. However, most prairie potholes and associated lakes contain alkaline water. Water accumulates rapidly in potholes during spring months, especially when soil frost is sufficiently deep to forestall all infiltration until after the ground thaws. Most water loss occurs through evapotranspiration, which exceeds precipitation during summer months.

Evapotranspiration is the primary water loss, although potholes also lose water by seepage. The concentration of dissolved solids results in water that ranges from fresh to extremely saline, with chemical characteristics varying seasonally and annually. Most prairie potholes and associated lakes contain water that is alkaline $(\mathrm{pH}>7.4)$.

Vegetation within this system is highly influenced by hydrology, salinity, and dynamics. Potholes can vary in depth and duration, which determines the local gradient of plant species. Similarly, species found within individual potholes will be strongly influenced by periodic drought and wet periods. The wettest sites, where water stands into or through summer, are characterized by hardstem bulrush (Schoenoplectus acutus), which often occurs as a near monoculture, or with a fringe of softstem bulrush (Schoenoplectus tabernaemontani) or common threesquare (Schoenoplectus pungens) along slightly drier margins (Figure $1.2 \mathrm{a}, \mathrm{b}$ ). Cattails (Typha species) are also seen in these wetter systems, although they are typically a minor component. During spring or in permanently flooded sites, aquatic buttercups (Ranunculus species), aquatic smartweeds (Polygonum species), pondweeds (Stuckenia and Potamogeton species or duckweeds (Lemna 


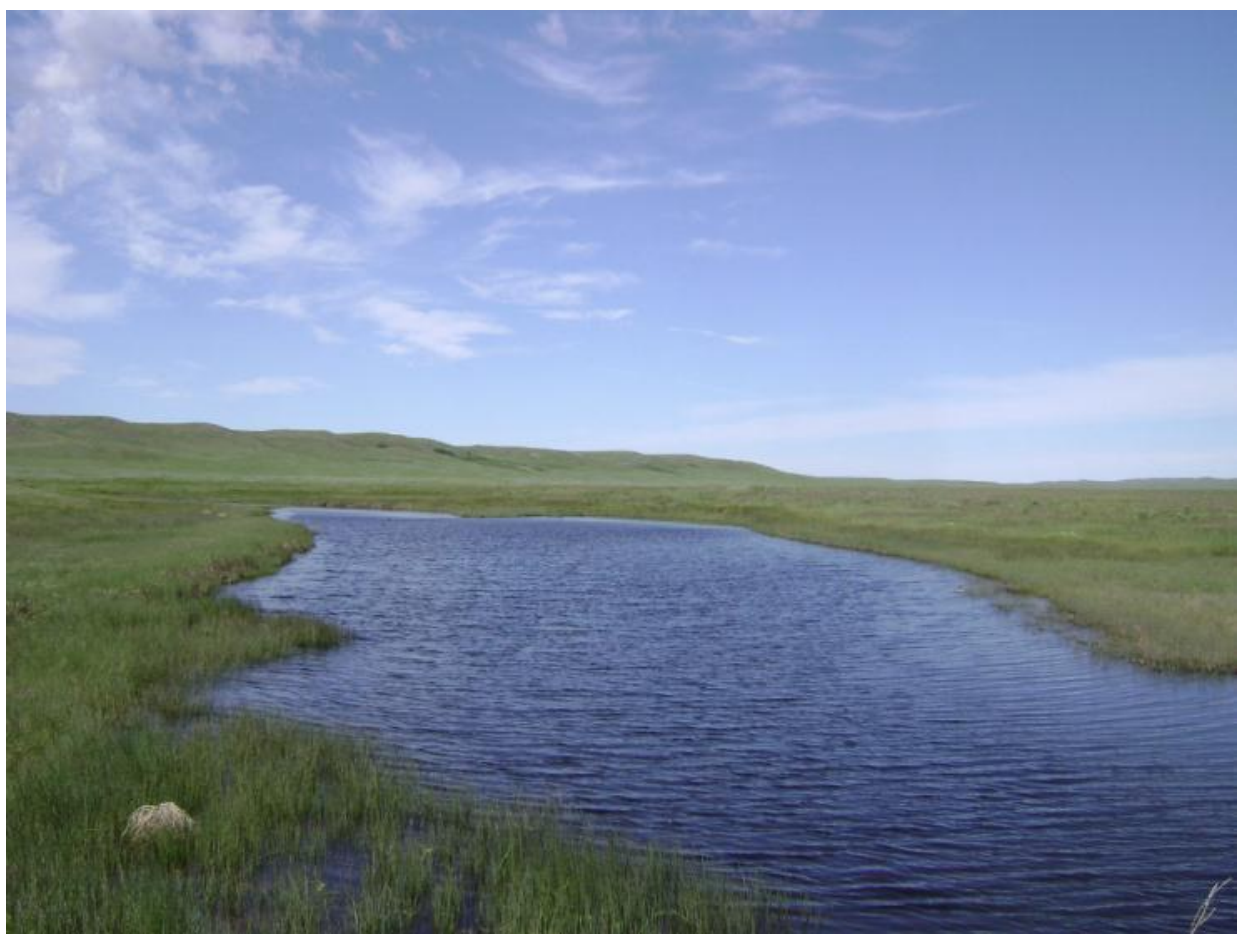

Figure 1.1 Great Plains Prairie Pothole (Photo by T. Luna)

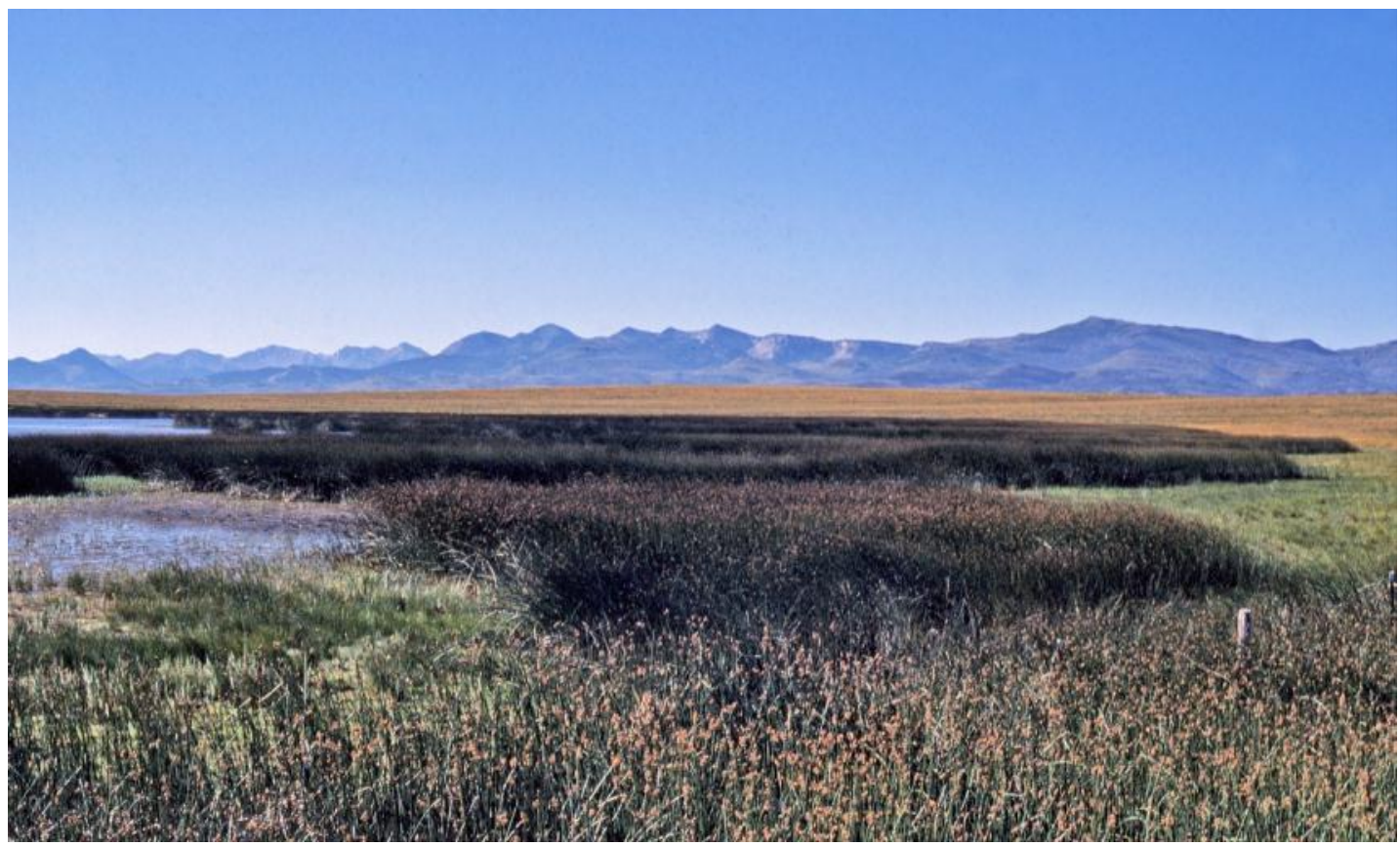

Figure 1.2a . Schoenoplectus acutus (Photo by T. Luna) 




Figure 1.2b Schoenoplectus pungens (Photo E.

Masin)

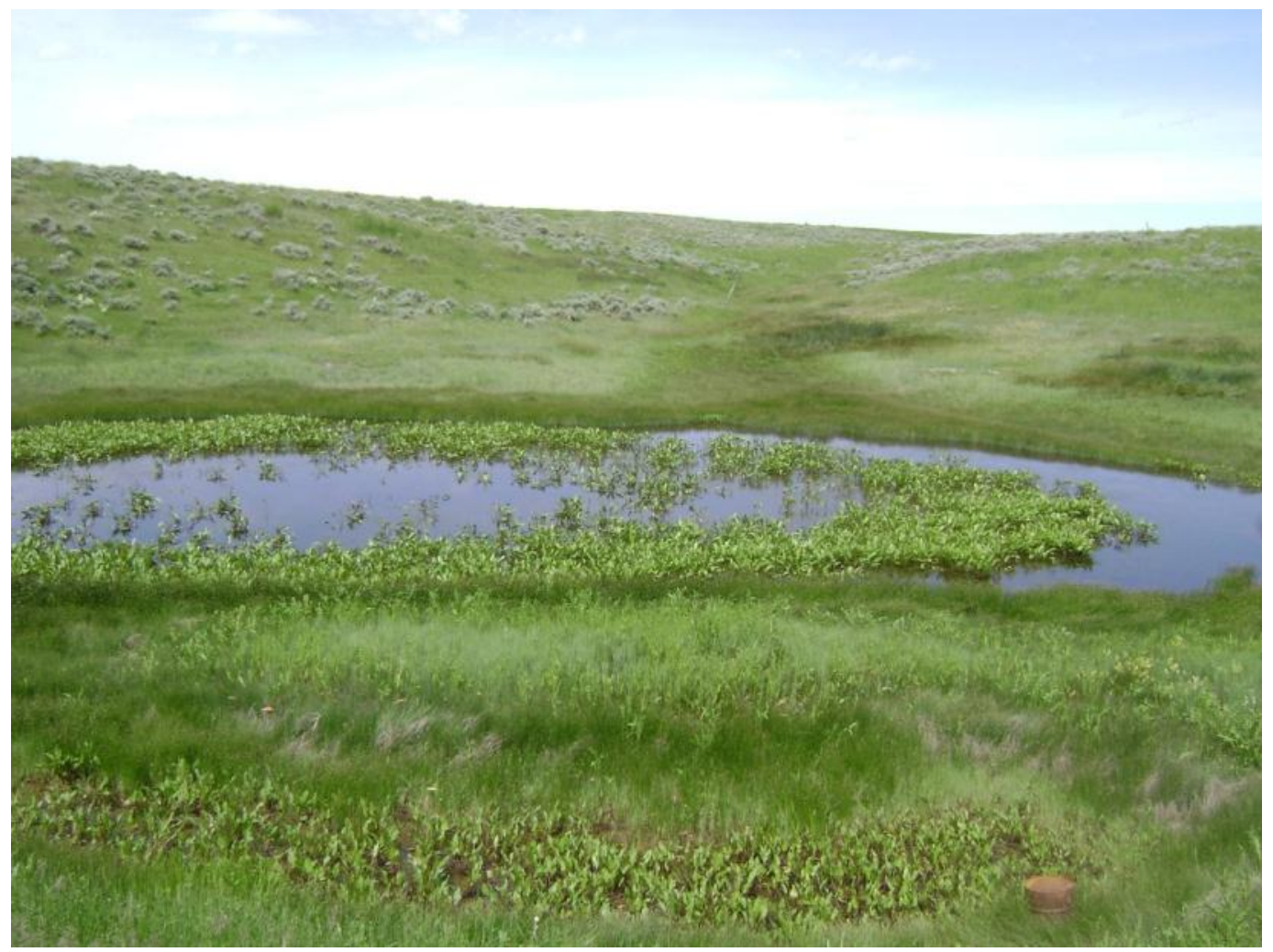

Figure 1.3. Concentric bands of vegetation (Photo T. Luna) 
species) may be abundant. At the drier extremes, pothole vegetation generally occurs in a concentric pattern from a wetter middle dominated by spikerush (Eleocharis species) through a drier ring of foxtail barley (Hordeum jubatum) and an outer margin of western wheatgrass (Pascopyrum smithii) or thickspike wheatgrass (Elymus lanceolatus) (Figure 1.3).

\section{Western Great Plains Open Freshwater Depression Wetland}

This ecological system is characterized by lowland depressions and occurs along lake borders that have more open basins and a permanent water source through most of the year (Figure 1.4). It occurs within larger watersheds and has a permanent water source throughout most of the year. Unlike the closed depressional wetland, this system typically has a significant connection to the groundwater table. Soils are typically Mollisols, Entisols, or occasionally Histosols. Soil $\mathrm{pH}$ varies from neutral to slightly alkaline. In Montana, this system is especially well represented along major and secondary tributaries of the Milk, Marias, and Two Medicine Rivers in the Northwestern Glaciated Plains region.

Open depression wetlands include submergent and emergent vegetation typically dominated by sedges (Carex species), spike rushes (Eleocharis species), rushes (Juncus species), bulrushes (Schoenoplectus species), and cattails (Typha species). Common sedges in this system include beaked sedge (Carex utriculata), inflated sedge (Carex vesicaria), Nebraska sedge (Carex nebrascensis), water sedge (Carex aquatilis), and wooly sedge (Carex pellita). Hardstem bulrush (Schoenoplectus acutus) is the most common species; however, softstem bulrush (Schoenoplectus validus) and alkali bulrush (Schoenoplectus maritimus) are often present.
Common spikerush (Eleocharis palustris), Baltic rush (Juncus balticus), and knotted rush (Juncus nodosus) are frequent on disturbed sites. Floating leaved species include pondweeds (Stuckenia and Potamogeton species), white water crowfoot (Ranunculus aquatilis), and broadleaf arrowhead (Sagittaria latifolia). Common submergents include common hornwort (Ceratophyllum demersum), short spike water milfoil (Myriophyllum sibiricum), and horned pondweed (Zannichellia palustris) (Figure 1.5). At montane elevations near the Rocky Mountain Front, these systems can be moderately complex with a variety of species and communities.

In semi-permanent open freshwater depressional systems, the drawdown zone is typically dominated by Northwest Territory sedge (Carex utriculata), water sedge (Carex aquatilis), and Nebraska sedge (Carex nebrascensis) (Figure 1.6). Open depressions with more alkaline or saline water and soil chemistry will typically be bordered by species such as seashore saltgrass (Distichlis spicata), western wheatgrass (Pascopyrum smithii), and alkali cordgrass (Spartina gracilis). In seasonal open depressions that draw down annually and in semi-permanent wetlands subjected to periods of drought, buried seeds of both annuals and perennials germinate covering exposed mud flats (Figure 1.7) with species such as mousetail (Myosurus minimus), toad rush (Juncus bufonis), and alkali buttercup (Ranunculus cymbalaria). Species richness can vary considerably among individual examples and is especially influenced by adjacent land use. Open depressional wetland systems are often bordered by linear or small patch wet prairie plant associations, dominated by grasses and sedges. Clustered field sedge (Carex praegracilis) and awned sedge (Carex atherodes) often occur along swales or stringers feeding into wetland depressional systems, or as small wet meadows in areas of low topography adjacent to the wetland Other graminoids include tufted hairgrass (Deschampsia cespitosa), 


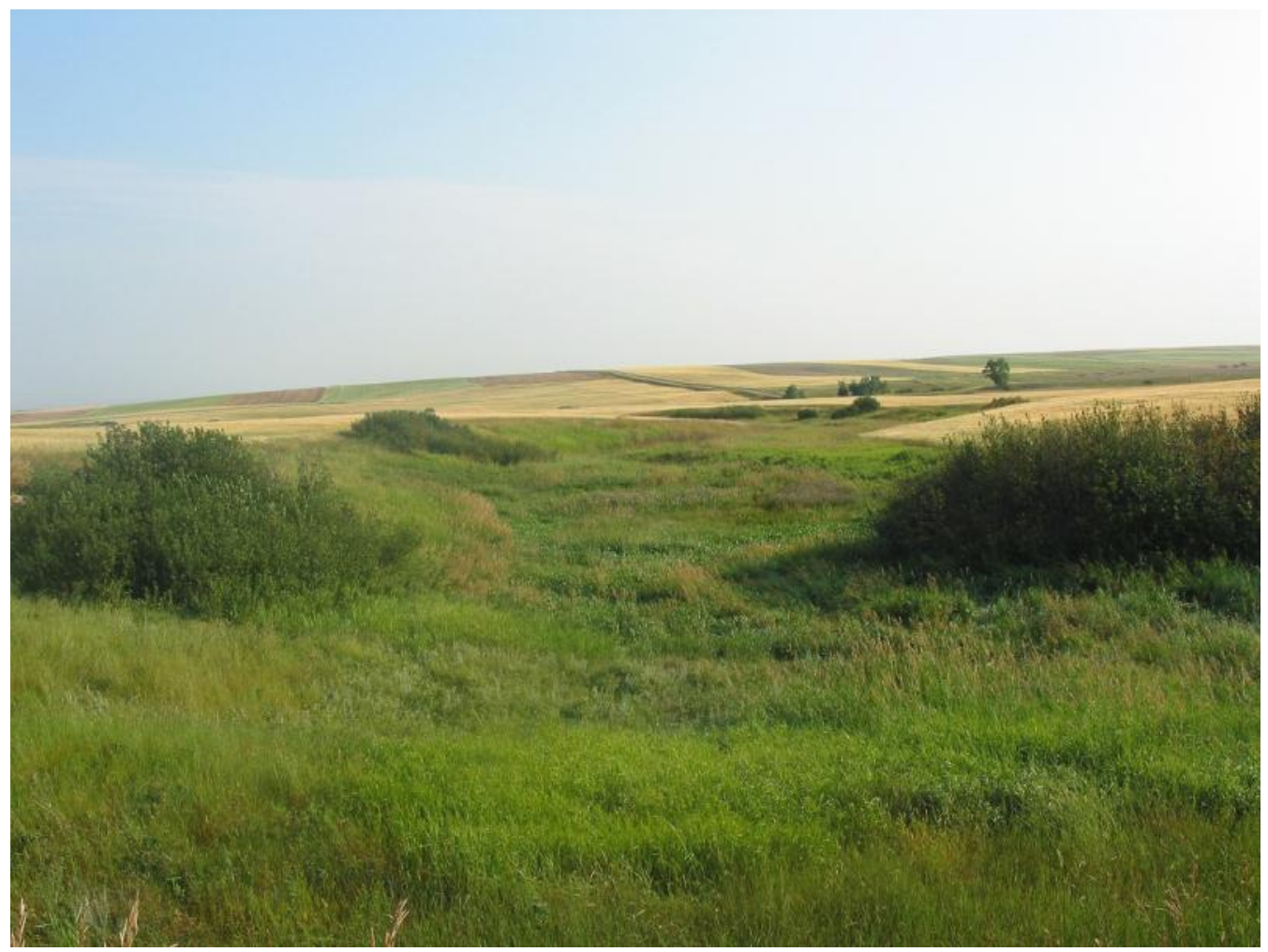

Figure 4. Great Plains Open Depression Wetland (Photo by L. Vance)

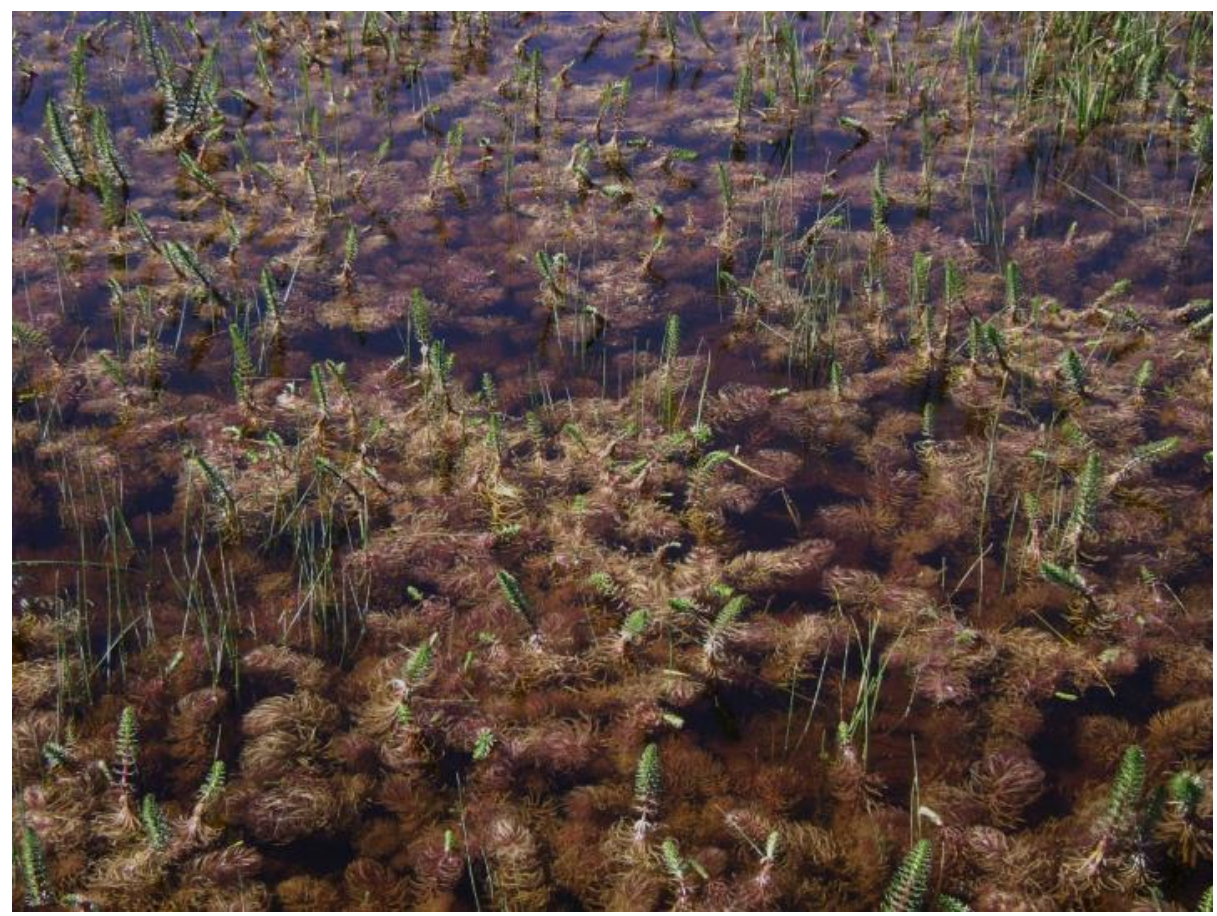

Figure 1.5 . Submergents and emergents (Photo T. Luna) 


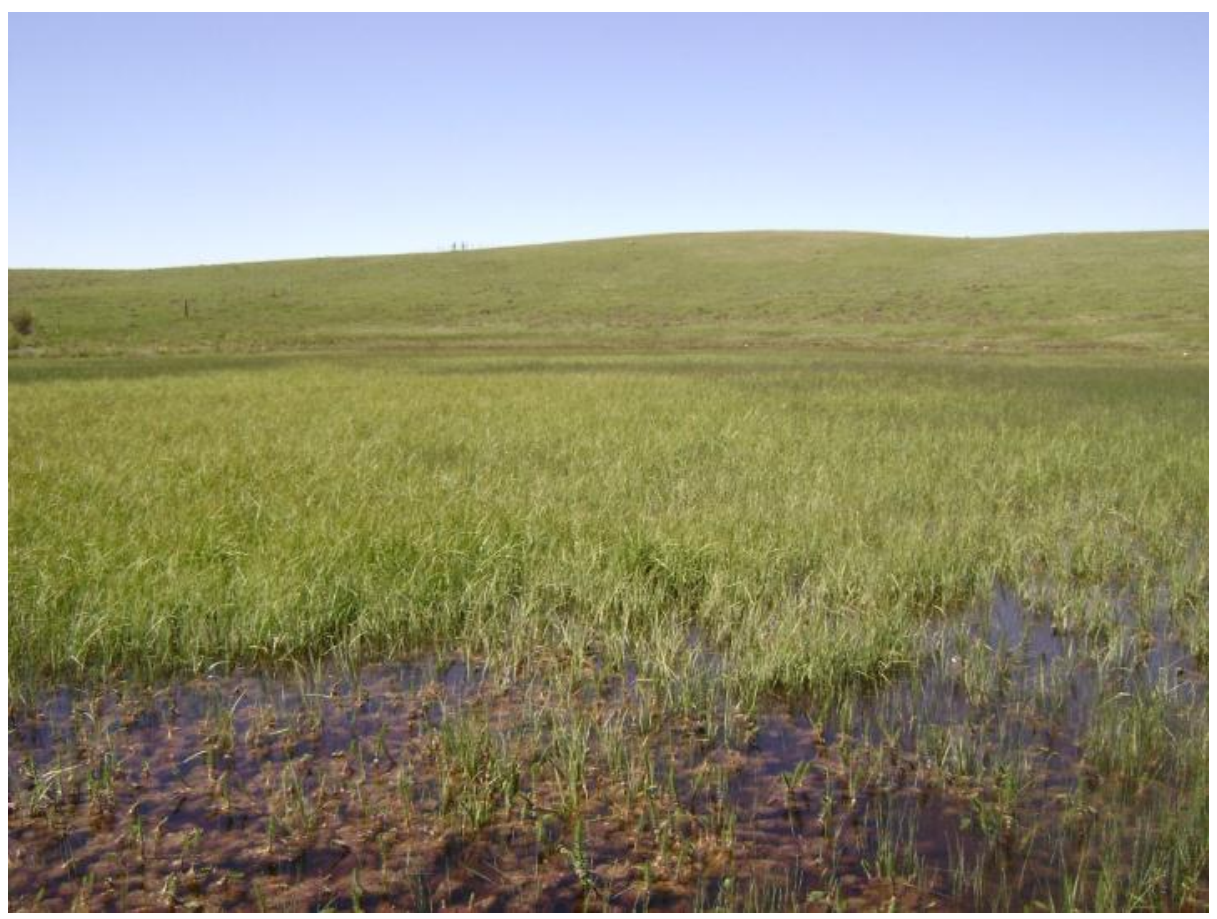

Figure 1.6. Carex utriculata (Photo T. Luna)

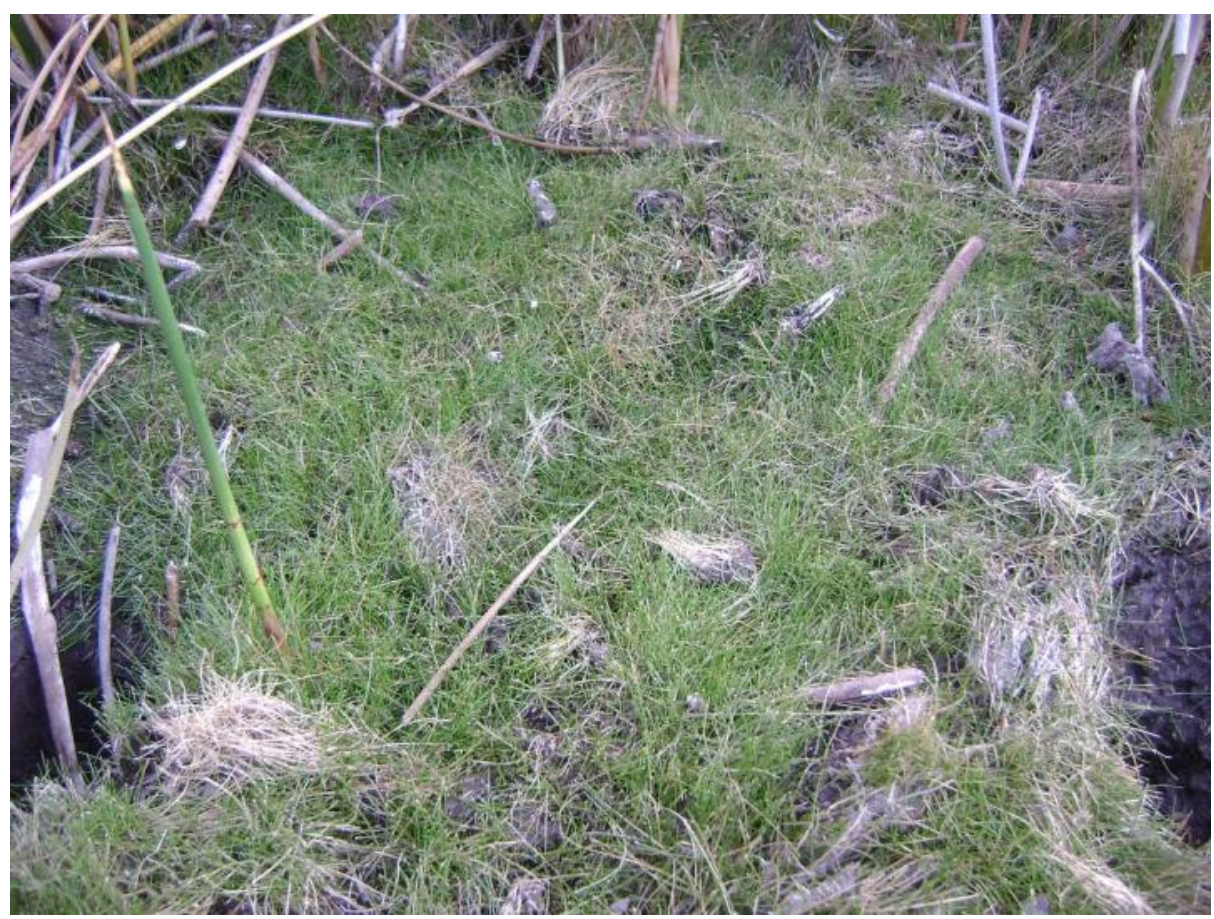

Figure 1.7. Annuals germinating in mudflat (Photo T. Luna) 
slimstem reedgrass (Calamagrostis stricta), bluejoint reedgrass (Calamagrostis canadensis), and fowl bluegrass (Poa palustris). Common forbs include heart leaf alexanders (Zizia aptera), marsh grass-of-parnassus (Parnassia palustris), meadow hawksbeard (Crepis runcinata), American licorice (Glycyrrhiza lepidota), white prairie aster (Symphyotrichum falcatum), western aster (Symphyotrichum occidentalis), dock (Rumex species), and Nuttall's sunflower (Helianthus nuttallii). More alkaline expressions of this system may include marsh arrowgrass (Trichglochin palustre). In some open depressional systems near the Rocky Mountain Front, there may be shrubs present on the perimeter of open depression, such as shrubby cinquefoil (Dasiphora fruticosa ssp. floribunda), western snowberry (Symphoricarpos occidentalis), Bebb willow (Salix bebbiana), redstem dogwood (Cornus sericea), thinleaf alder (Alnus incana), or birch (Betula species).

\section{Western Great Plains Closed Depression Wetland}

Closed depressional systems are similar to open depressional systems and prairie potholes, but are usually isolated depressions without obvious interwetland surface drainage systems (Figure 1.8). They are primarily small, depressional basins found on flat, enclosed upland areas or on level shallow lake basins. The major sources of input water are precipitation and snow melt, and water loss occurs through evapotranspiration. Although they are considered to be strictly isolated, closed depressions may contribute some recharge to the groundwater table. The basins are typified by the presence of an impermeable layer such as dense clay that is poorly drained. Subsurface soil layers are restrictive to water movement and root penetration. Closed depressions experience irregular hydroperiods where most fill with water only occasionally and dry quickly, influencing the plant communities.. The drawdown zone is typically dominated by western wheatgrass (Pascopyrum smithii) and foxtail barley (Hordeum jubatum) (Figure 1.9). Other grass species present in the drawdown zone may include inland saltgrass (Distichlis spicata) and prairie cordgrass (Spartina pectinata). Creeping silverweed (Argentina anserina), povertyweed (Iva axillaris), and willow dock (Rumex salicifolius) occupy the broad, low gradient basins which are shallowly inundated in the spring and drawdown every year. Needle spikerush (Eleocharis acicularis) and small annual forbs such as slender plantain (Plantago elongata) and purslane speedwell (Veronica peregrina) are found frequently. The common spikerush (Eleocharis palustris) association is also within the drawdown zone, but occurs when there is more organic matter present in the soil substrate.

In more shallow closed depressions subjected to long periods of drought and significantly reduced annual water input, foxtail barley (Hordeum jubatum) and needle spikerush (Eleocharis acicularis) are frequently the only species represented. Hardstem bulrush (Schoenoplectus acutus) can be found in closed depressional wetlands that are deep enough (1.5-2 m) to remain permanently inundated during most years. Forbs commonly associated with the hardstem bulrush community include water knotweed (Polygonum amphibium), common spikerush (Eleocharis palustris), and two headed water-starwort (Callitriche heterophylla). Closed depressional systems are similar to playas in the central and southern Great Plains region however, playas are distinct in terms of geologic origin, groundwater connectivity, landscape location, soils and plant communities. 


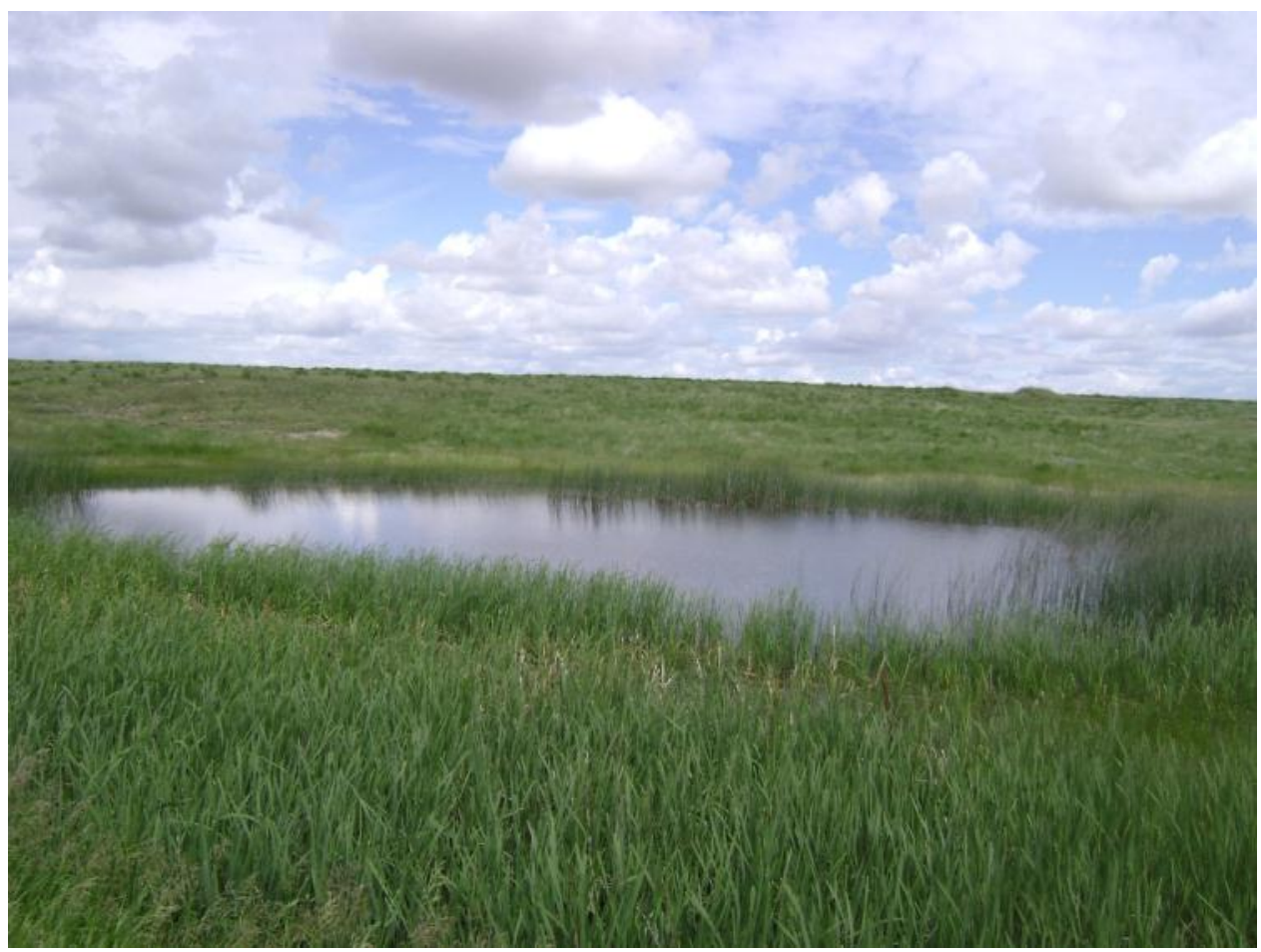

Figure 1.8. Western Great Plains Closed Depression Wetland (Photo T. Luna)

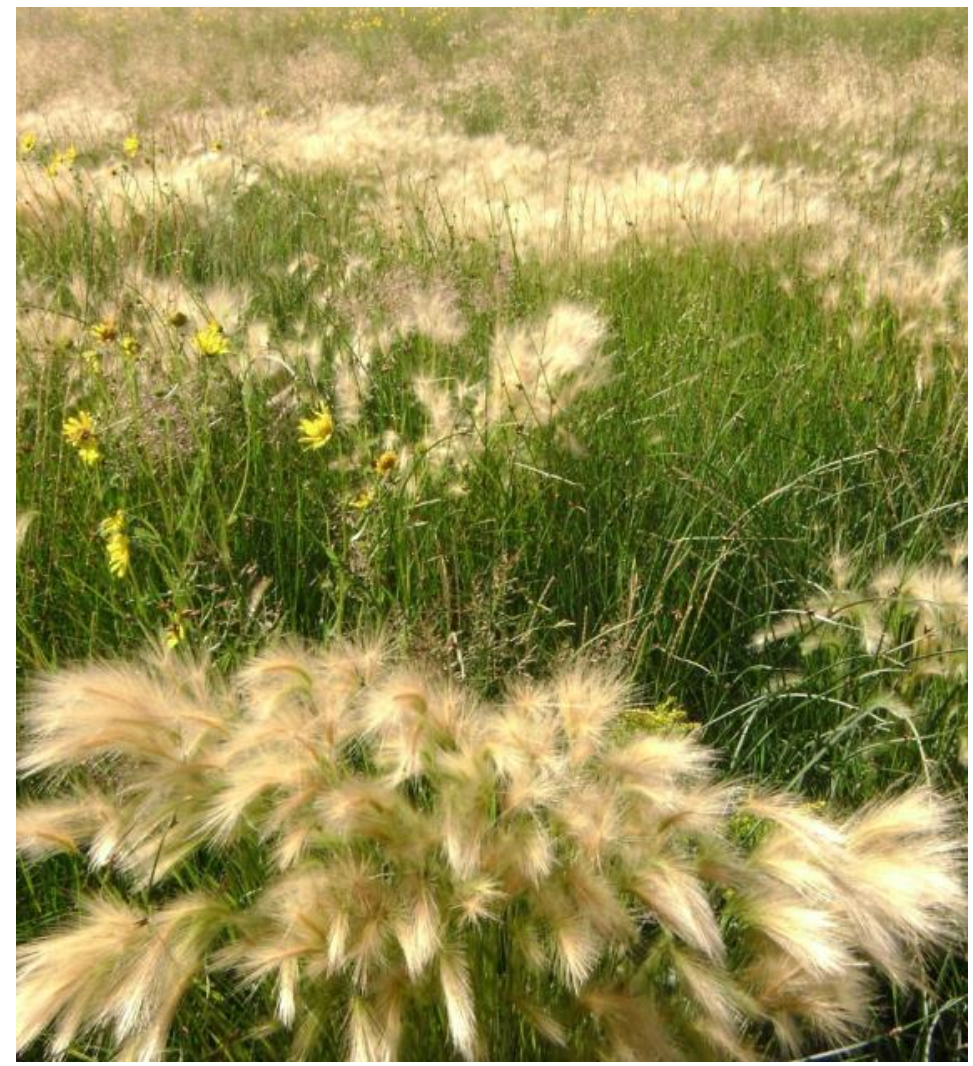

Figure 1.9. Hordeum jubatum in drawdown zone (Photo T. Luna) 


\section{Western Great Plains Saline Depression Wetland}

This ecological system is very similar to both the Western Great Plains Open Freshwater Depressional Wetland and the Western Great Plains Closed Depressional Wetland. However, this system differs in the high soil and water salinity that causes these systems to become brackish (Figure 1.10). This high salinity is attributed to increased evaporation and the accumulation of minerals dissolved in the water. This wetland system is typified by discharge wetlands, where water high in dissolved salts moves from the regional groundwater system into the depression. Hydroperiods vary depending on precipitation and snowmelt, the primary source of water. Water is prevented from percolating out of the depression by impermeable dense clay. Salt encrustations can occur on the surface due to slow water movement (Figure 1.11). On the Blackfeet Indian reservation, water samples collected from saline depressions had conductivity values that ranged from 1,550-40,000 $\mu \mathrm{mhos} / \mathrm{cm}$ (Lesica and Shelly 1988). Soils have silty-clay to clay texture, and the soil surface is covered with salt crusts. Principal salts are sulfates and chlorides of sodium and magnesium.

Vegetation within this system is highly influenced by soil salinity and soil moisture and is res salttolerant and halophytic species. Plant zonation related to soil salinity is often apparent in these systems with distinct rings occurring around the fringe of the depression (Figure 1.12). Common species in standing water include alkali bulrush (Schoenoplectus maritimus) and common threesquare (Schoenoplectus pungens). In extremely halophytic habitats, red swampfire (Salicornia rubra) is the dominant species. Red swampfire frequently occurs in the drawdown zone, i.e., the area that is flooded during the early part of the growing season but has a water table below the soil surface by late spring or early summer. It is one of a very few species that can persist in these hypersaline conditions.

Adjacent communities are defined by the salinity tolerance of other species. Adjacent to the red swampfire association, prairie cordgrass and Nuttall's alkali grass are frequently the dominant species. This community is often bordered by communities dominated by inland saltgrass and shrubs such as greasewood and winterfat (Krascheninnikovia lanata) around the outer margins of this system. Western wheatgrass and foxtail barley are frequently dominant in wet meadows adjacent to saline depressions.

In northeastern Montana, the alkali bulrush association occurs as an emergent band around open water or as zonal vegetation around other plant associations. Water tables are often high, often remaining above the soil surface at least through late summer. Soils are poorly drained, alkaline Entisols. Alkali bulrush forms dense, monotypic stands with up to $91 \%$ cover. In some areas along the wetland edge, very minor amounts of common spikerush (Eleocharis palustris) may be present. Alkali bulrush can survive periods of total inundation of up to $1 \mathrm{~m}$ (3.3 feet) deep, as well as drought periods where the water table remains up to $1 \mathrm{~m}$ below the soil surface. It is a vigorously rhizomatous species that colonizes and spreads when the water table is within $10 \mathrm{~cm}$ (4 inches) of the surface. Conversely, cover of alkali bulrush may be replaced by red swampfire during prolonged periods of drought.

\section{North American Arid West Emergent Marsh}

In Montana, this system is typically found in depressions surrounded by an upland matrix of mixed prairie, shrub steppe, or steppe vegetation. Natural marshes occur in and adjacent to ponds and prairie potholes, as fringes 


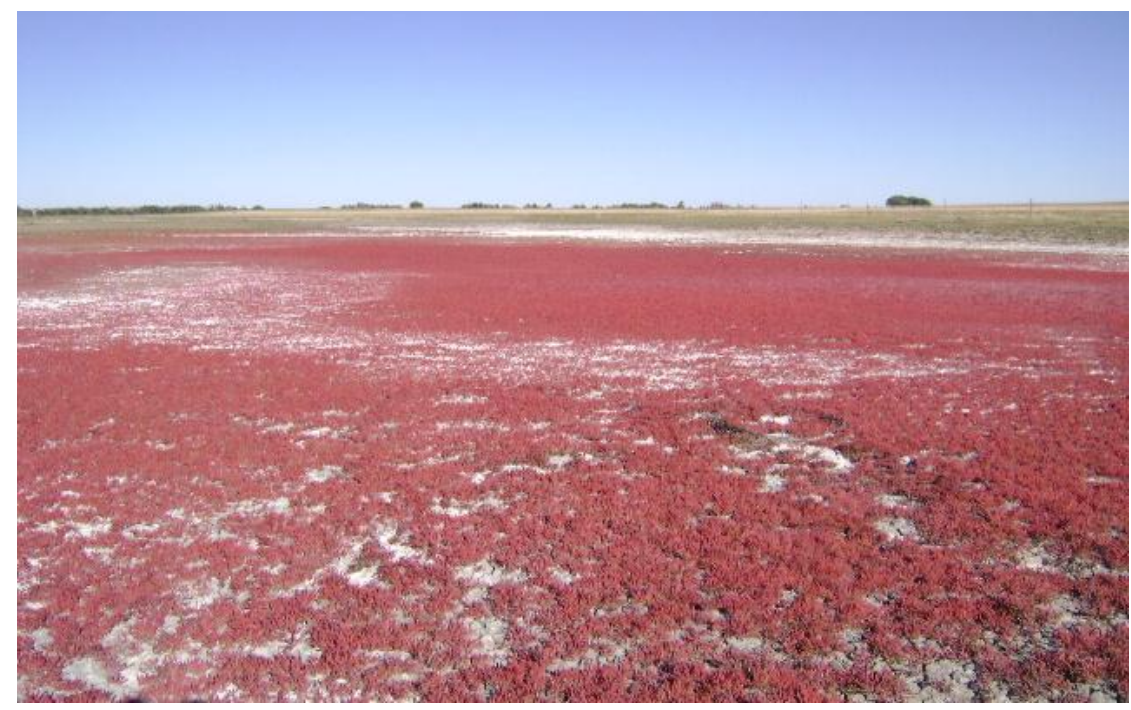

Figure 1.10 Western Great Plains Saline Depression (Photo T. Luna)

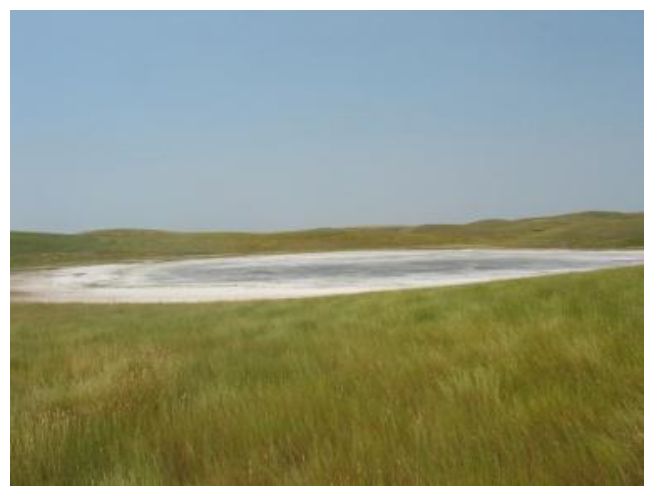

Figure 1.11 Salt crusts (Photo L.Vance)

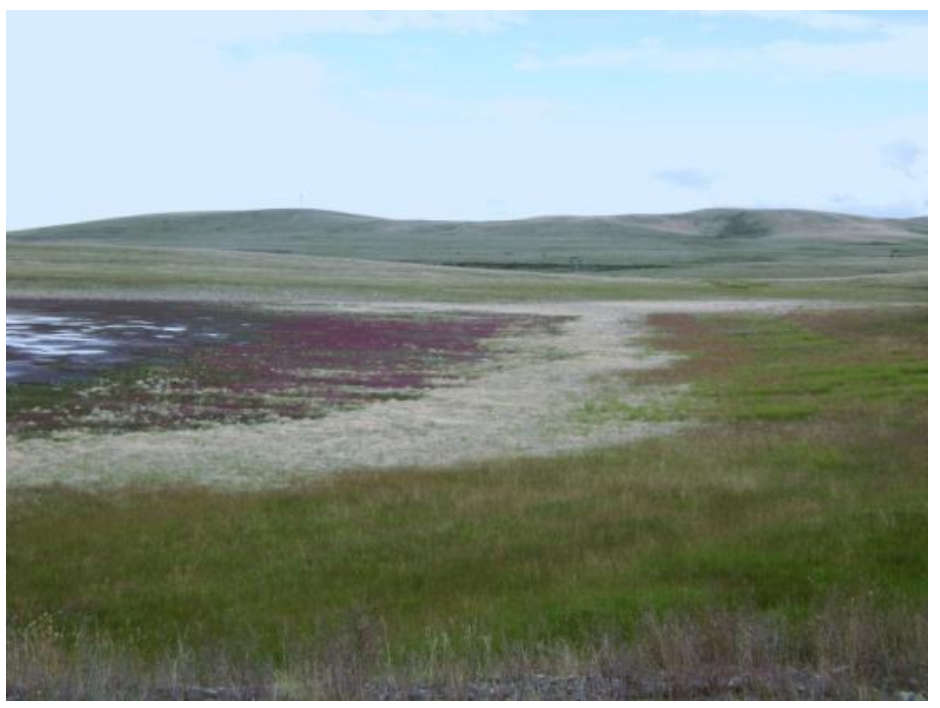

Figure 1.12. Saline drawdown zonation (Photo T. Luna) 
around lakes or oxbows, and along slow-flowing streams and rivers as riverine marshes (Figure 1.13). Water chemistry may include some alkaline or semi-alkaline sites, but the alkalinity is highly variable even within the same complex of wetlands. Marshes have distinctive soils that are typically mineral, but can also accumulate organic material. Soil profiles have characteristics that result from long periods of anaerobic conditions:gleyed soils, high organic content, and redoximorphic features.

Wetland marshes are classified as either seasonal or semi-permanent based on the dominant vegetation found in the deepest portion of the wetland (Stewart and Kantrud 1972). Vegetation communities that occur in these marsh systems are indicative of their hydroperiod, where some basins dry to bare soil after seasonal flooding while others will have a variety of wetland types in a zoned pattern dependent on seasonal water table depths and salt concentrations. A central shallow marsh zone that is dominated by graminoids and sedges characterizes seasonal marshes, while semipermanent wetlands that are continually inundated with water depths up to $2 \mathrm{~m}$ ( 6.5 feet $)$ will have a deeper, central marsh zone dominated by cattails (Typha species) and bulrushes (Schoenoplectus species) (Figure 1.14).

Vegetation communities change according to wetdrought cyclical events. In seasonal ponds that dry out annually and in semipermanent wetlands during drought years, buried seeds of both annuals and perennials germinate, covering exposed mud flats. In semi-permanent marshes, the drawdown zone is typically dominated by western wheat grass (Pascopyrum smithii) near the upland edge, with Northwest Territory sedge (Carex utriculata) and Nebraska sedge (Carex nebrascensis) as the dominant sedges occurring down gradient. Water sedge (Carex aquatilis) is frequently co-dominant with Northwest Territory sedge. Less commonly, blister sedge (Carex vesicaria) and awned sedge (Carex atherodes) are intermixed with Northwest Territory sedge or occur as co-dominants on similar sites. Broadleaf cattail (Typha latifolia) and hardstem bulrush (Schoenoplectus acutus) are found in the deeper, central portion of the marsh. Beyond the emergent vegetation, white water crowfoot (Ranunculus aquatilis) and pondweed (Stuckenia and Potamogeton species) may occur depending on water depth and hydroperiod. Other floating species such as duckweed (Lemna species) and submergents such as common hornwort (Ceratophyllum demersum), horned pondweed (Zannichellia palustris), mare's tail (Hippuris vulgaris), and water milfoil (Myriophyllum species) may be present in shallow water.

Seasonal marshes often possess distinct zonation of plant communities defined by hydroperiod. Dominant plant associations that occur in a gradient from dry (on the outer perimeter of the marsh) to wet (the deepest portion of the marsh) include western wheat grass (Pascopyrum smithii), Baltic rush (Juncus balticus), Nebraska sedge (Carex nebrascensis), beaked sedge (Carex utriculata), creeping spikerush (Eleocharis palustris) inflated sedge (Carex vesicaria), small floating mannagrass (Glyceria borealis), cattail, and hardstem bulrush. Common perennial forbs include common willow herb (Epilobium ciliatum), marsh cinquefoil (Comarum palustris), Gmelin's buttercup (Ranunculus gmelinii), greater creeping spearwort (Ranunculus flammula), hemlock water parsnip (Sium suave), willow dock (Rumex salicifolius), field mint (Mentha arvensis), leafy aster (Symphyotrichum foliaceum), and broadleaf arrowhead (Sagittaria latifolia). Fern allies such as water horsetail (Equisetum fluviatile) and field horsetail (Equisetum arvense) often form dense cover within seasonal marshes. Seasonal 


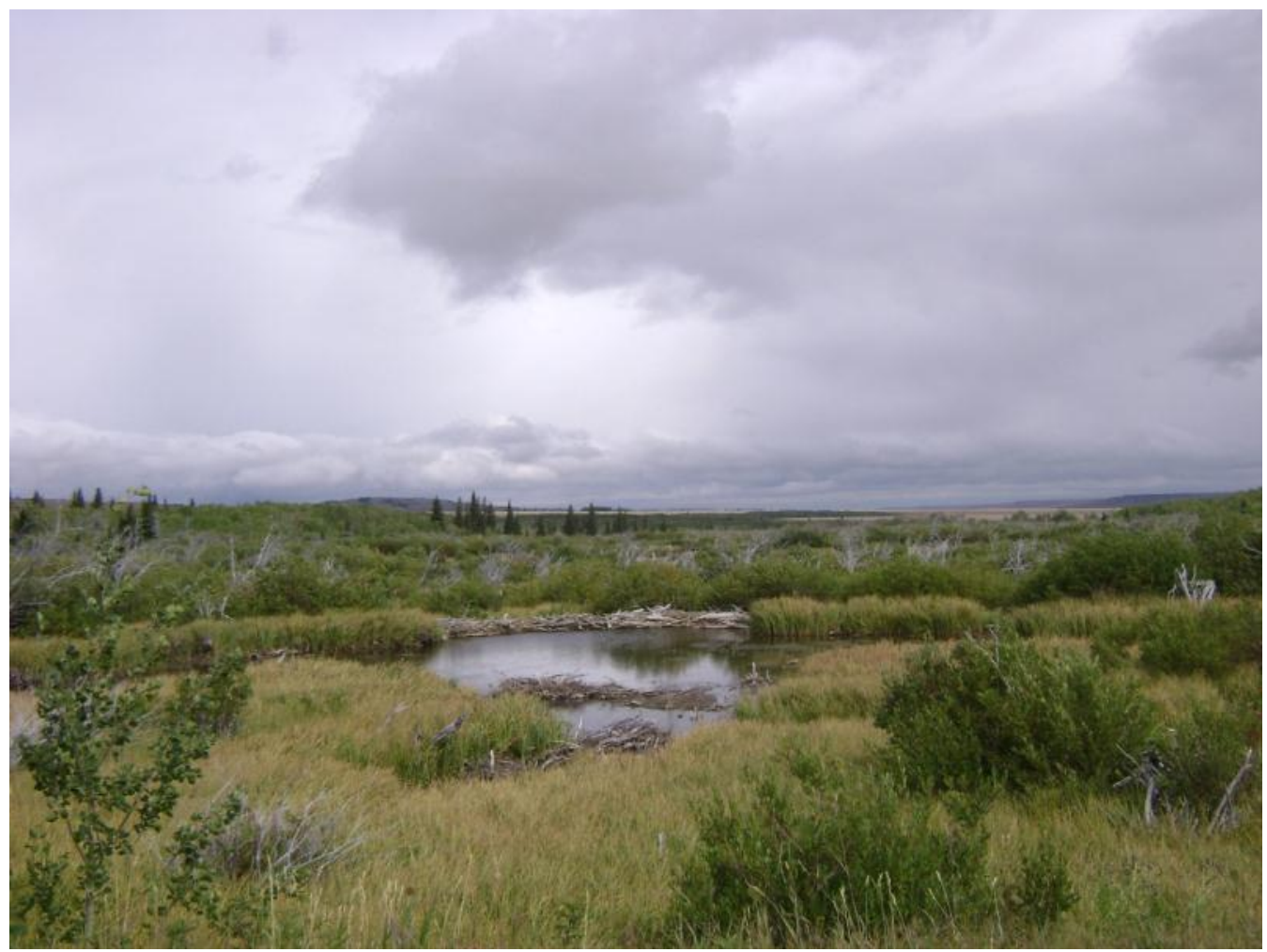

Figure 1.13. Riverine marsh with beaver activity (Photo T. Luna)

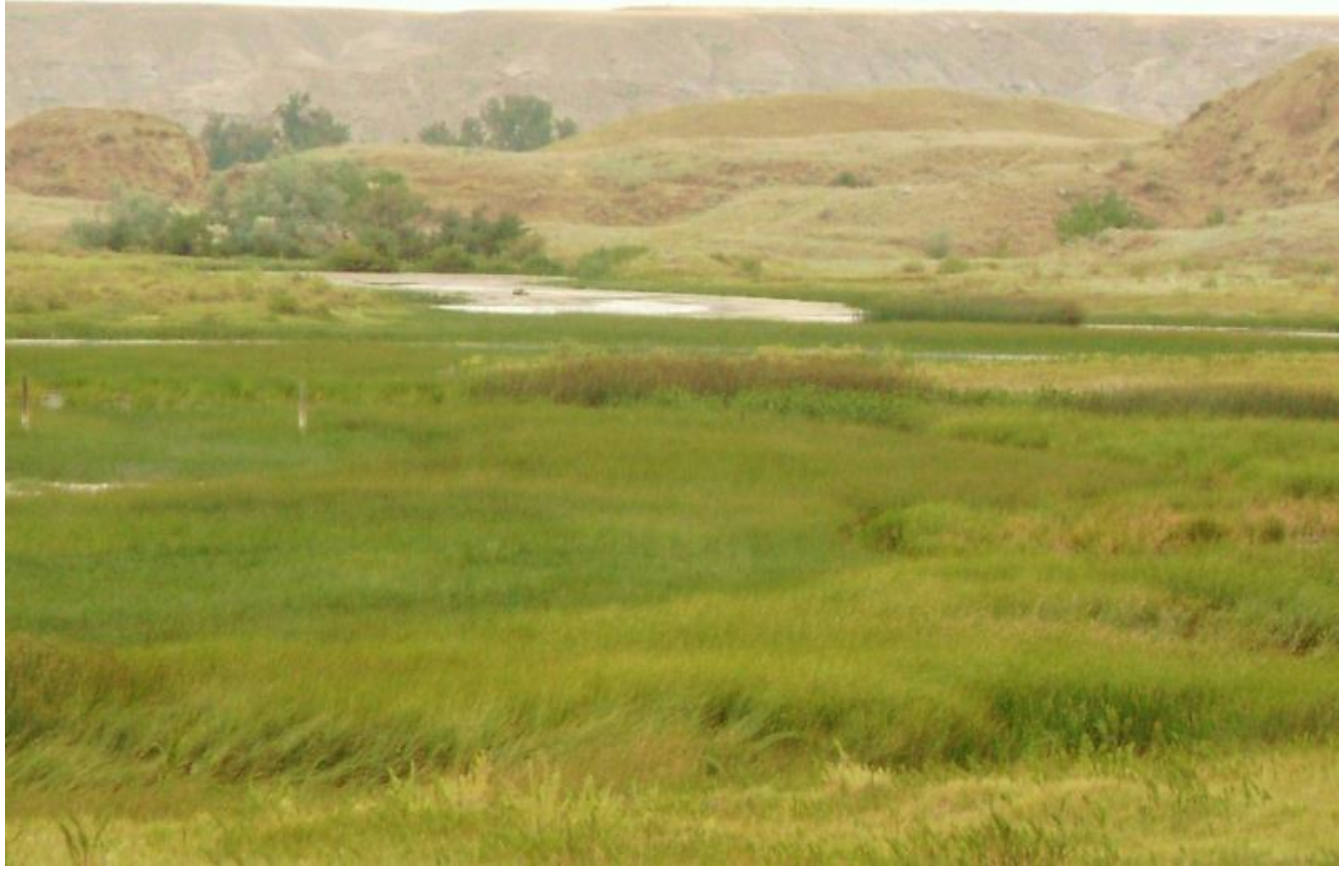

Figure 1.14. Central marsh zone with cattails (Photo T. Luna) 
marshes are frequently bordered by wet meadows dominated by grasses such as tufted hairgrass (Deschampsia caespitosa) and bluejoint reedgrass (Calamagrostis canadensis).

Seasonal and semi-permanent marshes with more alkaline water chemistry are found throughout north-central and northeastern Montana. Typical species include hardstem bulrush, cattail, common threesquare (Schoenoplectus pungens), alkali bulrush (Schoenoplectus maritimus) and inland saltgrass (Distichlis spicata). Red swampfire (Salicornia rubra) and prairie cordgrass (Spartina pectinata) occur in adjacent drawdown zones. These communities are brackish marshes and support species adapted to saline and alkaline water and soil conditions, similar to Western Great Plains Saline Depression systems.

Typically, riverine marshes subjected to unaltered, seasonal water flow and annual flooding are characterized by zonal vegetation determined by water depth with stands of bulrush (Schoenoplectus species), softstem bulrush (Schoenoplectus tabernaemontani), and cattail in deeper water, and manna grass (Glyceria species), water sedge, inflated sedge, water horsetail and common spikerush in shallower water zones. Riverine marshes can be influenced by beaver activity and human-caused influences that can change the structure and species richness of these plant communities. Beaver activity can increase species richness and diversify community structure by altering water flow, depth, and organic sediment accumulation.

Wet-drought year climactic cycles in Montana influence the ecological communities in these systems (Hansen et al. 1996). During this climactic cycle, wetlands go through a dry marsh, regenerating marsh, degenerating marsh and a lake phase that is regulated by periodic drought and deluge. During drought periods, seeds from annuals and perennials germinate and cover exposed mud lats, but when precipitation floods the depressions, the annuals drown and the perennials survive, regenerating the marsh. Over a series of years, perennials dominate and submersed and floating-leaved hydrophytes return. After a few years of the regenerating phase, emergent vegetation begins to decline and eventually the marsh reverts to an open water system. Muskrats may play an important role in the decline of emergent vegetation in some of these systems. During drought, the drawdown to mudflats is necessary so that emergent vegetation can become reestablished. Flooding, drawdown, and the eventual exposure of mud flats drive the waterlevel vegetation cycle. In saline soil marshes, increased precipitation during exceptionally wet years can dilute the salt concentration in the soils, allowing for less salt-tolerant species to occur. Species richness can vary considerably among individual examples and is especially influenced by adjacent land use.

\section{Rocky Mountain Subalpine-Montane Fen}

Fens are found in scattered locations along the Rocky Mountain Front on the western edge of the Great Plains and are well represented on the Blackfeet Indian Reservation (Figure 1.15). They occur throughout the Rocky Mountains, usually in forested systems, and are important wetland habitats for many species of concern. Although very rare, ecologically significant fens occur farther east in the northern Great Plains of Montana within mixed grass prairie (Figure 1.16).

Fens are confined to specific environments defined by groundwater discharge, soil chemistry, and peat accumulation. Fens form at low points in the landscape or near slopes where groundwater intercepts the soil surface. Groundwater inflows maintain a fairly constant water level year-round, with water at or near the surface most of the time. 


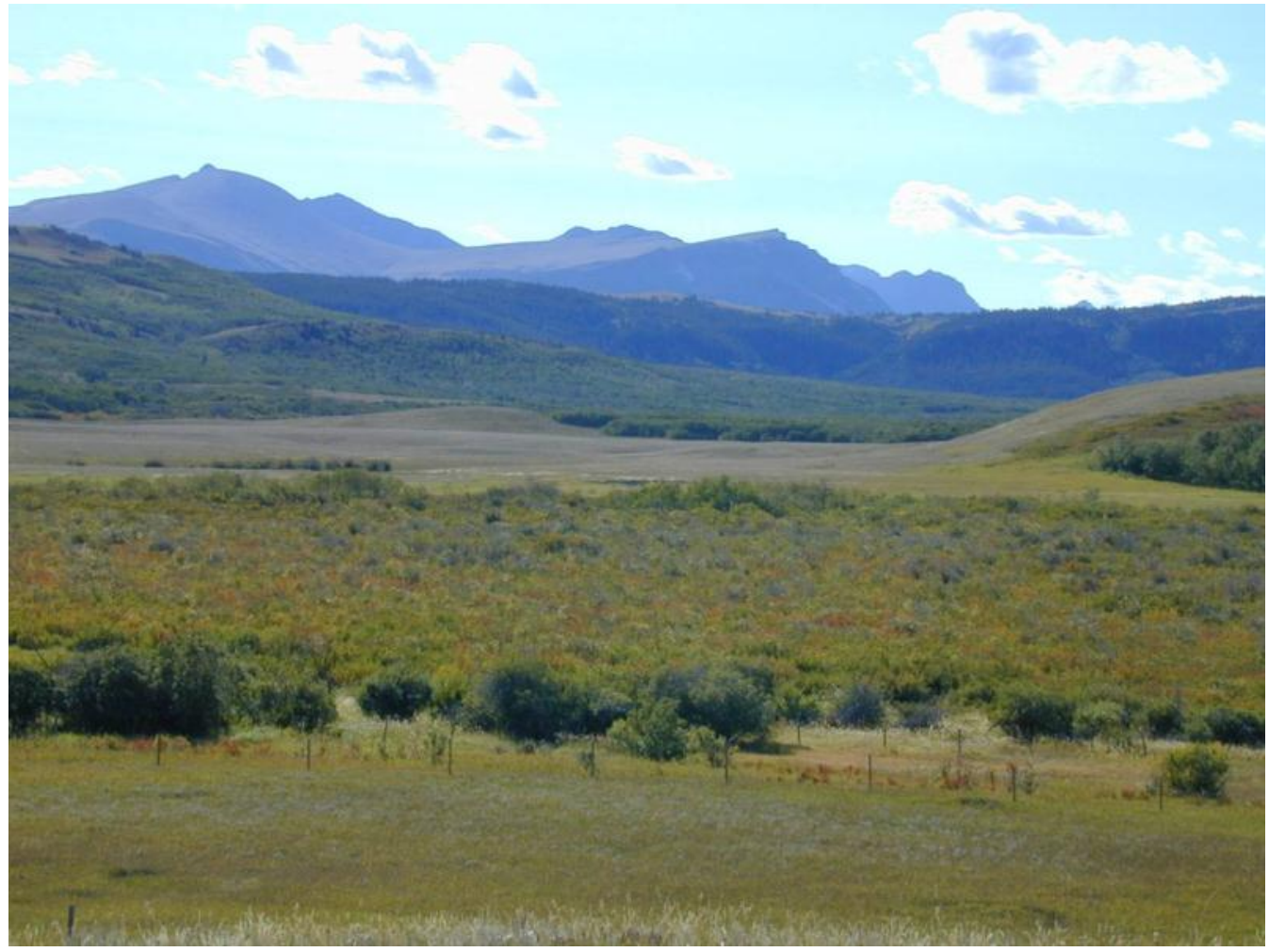

Figure 1.15. Flatiron Creek fen, Blackfeet Reservation (Photo A. Gladstone)

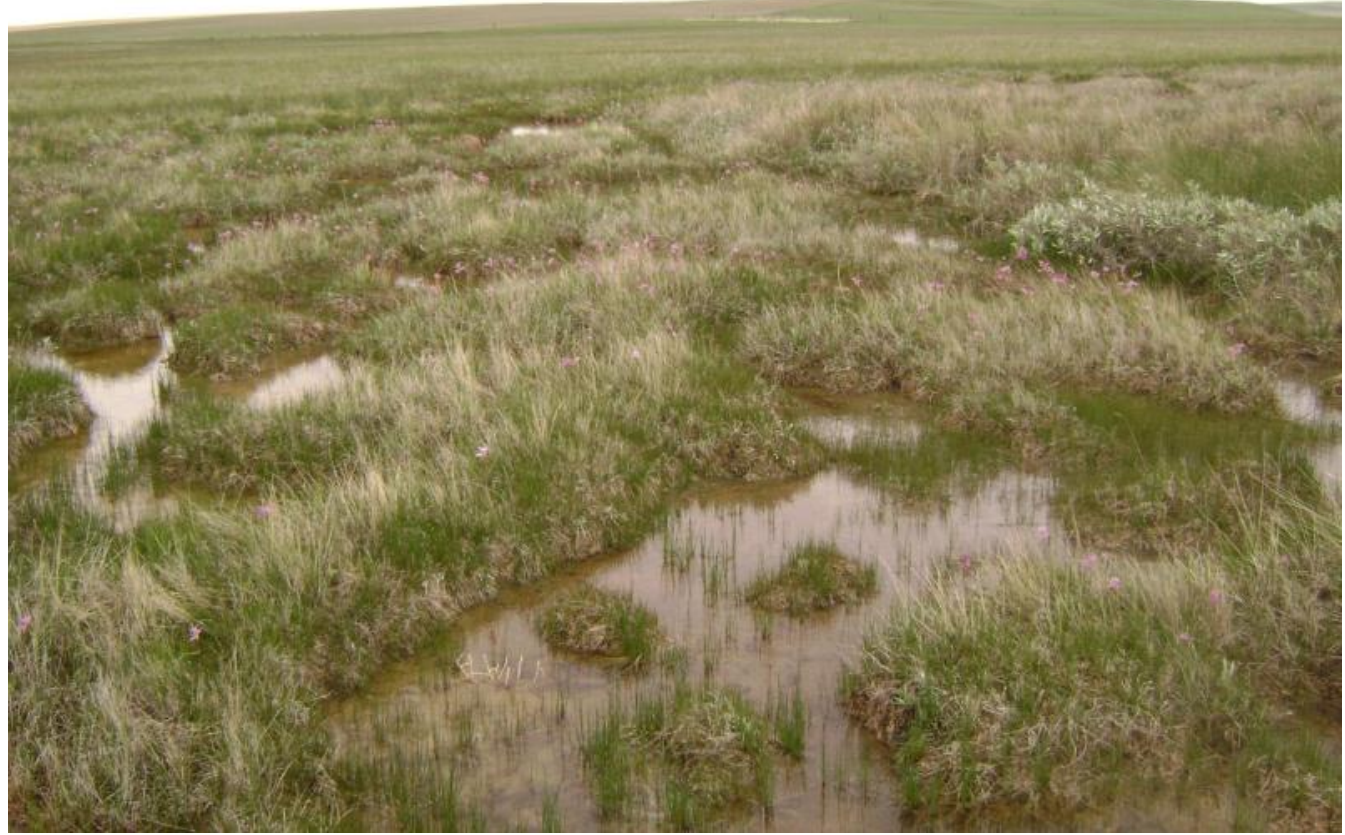

Figure 1.16. Extremely rich prairie fen (Photo T. Luna) 
Constant high water levels lead to accumulation of peat, usually greater than $40 \mathrm{~cm}$ (15 inches) except on sites underlain by bedrock. Many examples of this system along the Rocky Mountain Front possess peat layers greater than $1 \mathrm{~m}$ deep.

Fens form at low points in the landscape or near slopes where groundwater intercepts the soil surface. In addition to peat accumulation and perennially saturated soils, extremely rich and iron fens have distinct soil and water chemistry, with high levels of one or more minerals such as calcium, magnesium, or iron. Water chemistry ranges from only slightly acidic to alkaline and is usually distinctly calcareous. Marl deposits (precipitated calcium carbonates) are common in these systems. Tufa deposits or terraces can be seen in some rich fens; these are composed of virtually pure calcium carbonate at the soil surface, formed by continuous discharge and evaporation of calcite saturated groundwater. In northwestern Montana, $\mathrm{pH}$ values usually range from 5.9-8.4 (Chadde et al. 1998).

Flow-through fens are the most common in the northern Rocky Mountains and western Great Plains. They occur along springs, streams, slopes and benches with a constant inflow and outflow of calcium-rich water. They are characterized by a series of linear hummocks oriented perpendicular to the slope. Carr shrubland is well developed in flow-through fens due to well-aerated, nutrient-rich water near the inflow and outflow zones. Usually there is an open, nutrient-poor community in the central portion of the fen. Floristically, rich and extremely rich fens support the greatest vascular plant species diversity of all peatland types in the Rocky Mountains.

Extremely rich fens are characterized by high species diversity, and are a complex mosaic of herbaceous and woody plant dominated communities. The herbaceous community is frequently itself a complex mosaic of graminoid dominated, species rich communities. Common plant associations include beaked sedges (Carex utriculata or Carex rostrata), water sedge (Carex aquatilis), mud sedge (Carex limosa), woolyfruit sedge (Carex lasiocarpa), spikerush (Eleocharis species), cottongrass (Eriophorum species), rushes (Scirpus species and Trichophorum species), and bulrushes (Schoenoplectus species). Other frequent species include Buxbaum's sedge (Carex buxbaumii), analogue sedge (Carex simulata), northern bog sedge (Carex gynocrates), bristlystalked sedge (Carex leptalea), poor sedge (Carex paupercula), yellow sedge (Carex flava), hair sedge (Carex capillaris), silvery sedge (Carex canescens), lens sedge (Carex lenticularis), Baltic rush (Juncus balticus), northern rush (Juncus alpino-articulatus), dagger leaf rush (Juncus ensifolius), threadleaf rush (Juncus filiformis), common spike rush (Eleocharis palustris), and few-flowered spike rush (Eleocharis quinqueflora). Common grasses include bluejoint reedgrass (Calamagrostis canadensis), tufted hairgrass (Deschampsia cespitosa), and fringed brome (Bromus ciliatus).

Forb diversity within these herbaceous communities is typically very high. Common species include showy pussytoes (Antennaria pulcherrima), bog orchid (Plantanthera species), buckbean (Menyanthes trifoliata), elegant death camas (Zigadenus elegans), grass-of-parnassus (Parnassia species), beautiful shooting-star (Dodecatheon pulcherrinum), pink elephant's head (Pedicularis groenlandica), arrow-grass (Triglochin palustris), and Siberian chives (Allium schoenoprasum). In Montana, wet floating Sphagnum-dominated mats are associated with open water edges or depressional areas of fens. Bryophyte floating mats often consist of Meesia moss (Meesia triquetra) and Scorpidium moss 
(Scorpidium species), and Magellan's peatmoss (Sphagnum magellanicum) and brown peatmoss (Sphagnum fuscum). The bryophyte floating mat supports a very minor component of sedges such as mud sedge (Carex limosa), and small sedges such as grape sedge (Carex aurea), softleaf sedge (Carex disperma), inland sedge (Carex interior), and cottongrass species (Eriophorum species). Buckbean (Menyanthes trifoliata) is a late seral species from the sedge mat phase that is often present on floating mats.

Fens are frequently bordered by willow-bog birch (Salix species-Betula nana, glandulosa) dominated carr shrublands. Carr shrubland is well developed in flow-through fens due to well-aerated nutrientrich water near the inflow and outflow zones or the perimeter of basin fens. Sageleaf willow (Salix candida) is an indicator species, and is frequently the dominant willow species present (Figure 1.17). Other willow species include autumn willow (Salix serrissima), Bebb's willow (Salix bebbiana), Drummond's willow (Salix drummondiana), and plane-leaf willow (Salix planifolia). Other shrubs include alder (Alnus species), bog birch (Betula nana), alder buckthorn (Rhamnus alnifolia), and shrubby cinquefoil (Dasiphora fruticosa). The surrounding landscape may be ringed with other wetland systems: fens often grade into marshes, wet meadows or riparian shrublands, and can be surrounded by conifer swamps or wet to mesic coniferous forests. Engelmann spruce (Picea engelmannii) is the most frequent conifer species associated with fens and forested fen margins of these systems near the Rocky Mountain front (Hansen et al. 1996).

Western Great Plains extremely rich prairie fens are rare but occur farther east from the Rocky Mountains in north-central and northeastern Montana (Heidel et al. 2000). These fens are typically open graminoid-dominated communities on permanently saturated peat sustained by mineral -rich groundwater discharge, with little influence from surface water inputs. They are flow-through fens and peat is sometimes mounded or domed. Small, shallow, marl-rich pools are often present (Figure 1.18). These shallow pools include submergents such as common bladderwort (Utricularia macrorhiza), lesser bladderwort (Utricularia minor), coon's tail (Ceratophyllum demersum) and Chara species, a calciphilic macroalgae that contributes to calcium carbonate precipitation (Heidel et al. 2000). Emergents within the pools include few-flowered spikerush and other small clubrushes and spikerushes. Hummocks and stringers bordering the open water pools are frequently dominated by a diversity of graminoids and forbs. Moss cover is variable and is typically composed of brown mosses with Sphagnum absent.

Extremely rich prairie fens share some similar floristic characteristics with extremely rich prairie fens found in North Dakota (Stewart and Kantrud 1972), including carr shrubland dominated by sageleaf willow. The herbaceous community also contains many of the same graminoids and forbs. Some of the more distinctive species of extremely rich prairie fens that are very infrequent in Rocky Mountain fens include mat muhly (Muhlenbergia richardsonis), slimstem reedgrass (Calamagrostis stricta), Kalm's lobelia (Lobelia kalmii), alkali buttercup (Ranunculus cymbalaria), seaside arrowgrass (Triglochin maritima), marsh arrowgrass (Triglochin palustris), and marsh grassof parnassus.

Examples of rich prairie fens typically occur on depressional sites where the water table is at or close to the surface throughout the year. The peat layer is significant; in some cases, a peat dome is formed in the center of the depression. Woolyfruit sedge and water sedge are the usual dominant graminoids. Nebraska sedge and knotted rush (Juncus nodosus) increase in cover 


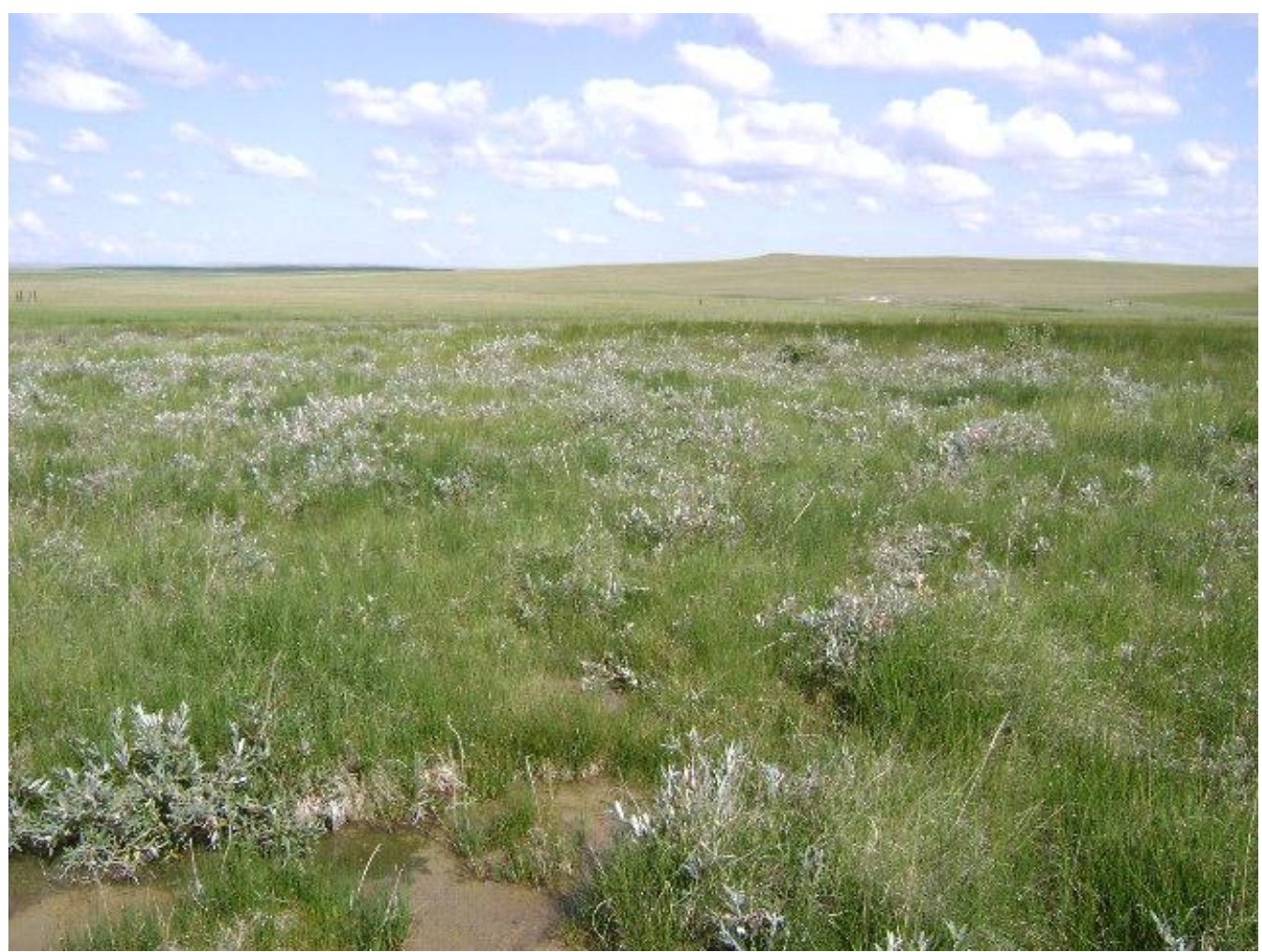

Figure 1.17. Salix candida in rich prairie fen (Photo T. Luna)



Figure 1.18. Pools in rich prairie fen (Photo T. Luna) 
under disturbance. Common forbs include western water hemlock (Cicuta douglasii), violet (Viola species), marsh hedgenettle (Stachys palustris), rough bugleweed (Lycopus asper), and marsh skullcap (Scutellaria galericulata). Species diversity is lower than seen in extremely rich prairie fens.

Land uses surrounding fens can potentially alter the hydrology and nutrient inputs of these systems, thus changing their underlying processes and plant communities. Increased land use within 100 $\mathrm{m}$ has been correlated with increased nutrient levels in peatlands in Montana; setbacks should be $100 \mathrm{~m}$ or greater to adequately manage these type of wetland systems (Jones 2003). Increased nutrient runoff from agricultural land use can alter species composition. Changes in nitrogen and phosphorous levels in particular can eliminate many species that are restricted to high calcium/ magnesium rich environments. Draining, prolonged drought periods, heavy cattle use, and irrigation practices alter hydrology and result in the loss of species diversity. Heavy cattle use in a fen system can alter the hydrology by damaging soils within the system. Soil compaction and pugging within the peat layer will change surface water flow. Heavy cattle use can also alter the successional processes within the graminoid dominated community of a fen by creating microsites where shrubs can become established over time, even after grazing is removed, by changing the sedge dominated meadow to carr shrubland.

\section{Greasewood Flat}

In Montana, this ecological system represents one of the driest extremes of the riparian/wetland zone. It is found in central, north-central, and eastern Montana and as a minor occurrence in southwestern Montana. The Greasewood Flats system occurs on nearly level, older alluvial terraces on broad or narrow floodplains (Figure 1.19). It may also occur on broad expanses along lake shores and depressional wetland complexes. Soils are saline or alkaline underlying a shallow water table. Flooding occurs intermittently; however, this ecological system remains dry during most of the year and during most growing seasons. The water table remains high enough to maintain vegetation, despite salt accumulations. Greasewood Flats occur where overland water flow or soils or a combination of both allow for greater than normal moisture regime. High water tables are common, typically within $25-30 \mathrm{~cm}$ (10-12 inches) of the soil surface. Soils are very fine textured, poorly drained alkaline or saline clays or silts. Most sites range in elevation from 655-1067 m (2150-3500 feet) (Hansen et al. 1996).

Greasewood (Sarcobatus vermiculatus) is the dominant shrub present, although overall canopy cover may be low. Other shrubs that may be present include four-wing saltbush (Atriplex canescens), shadscale saltbush (Atriplex confertifolia), Gardner's saltbush (Atriplex gardneri), Wyoming big sagebrush (Artemisia tridentata ssp. wyomingensis), Basin big sagebrush (Artemisia tridentata ssp. tridentata), silver sage (Artemisia cana ssp. cana), green rabbitbrush (Chrysothamnus viscidiflorus), rubber rabbitbrush (Ericameria nauseosa), or winterfat (Krascheninnikovia lanata).

Perennial grasses have the highest herbaceous cover, with western wheatgrass (Pascopyrum smithii) having the highest cover in undisturbed communities. Other graminoids include slender wheatgrass (Elymus trachycaulus), prairie cordgrass (Spartina pectinata), Nuttall's alkaligrass (Puccinellia nuttalliana), Sandberg's bluegrass (Poa secunda), inland saltgrass (Distichlis spicata), alkali sacaton (Sporobolus airoides), prairie sandgrass (Calamovilfa longifolia), basin wildrye (Leymus cinereus), and occasionally common spikerush (Eleocharis palustris). Common forb species include yarrow 
(Achillea millefolium), one flowered groundsel (Pyrrocoma uniflora), boreal sagewort (Artemisia frigida), western sagewort (Artemisia ludoviciana), goosefoot (Chenopodium species), scarlet globe mallow (Sphaeralcea coccinea), western saltwort (Salicornia rubra), and curlycup gumweed (Grindelia squarrosa).

Adjacent drier communities are dominated by upland shrub or grassland communities such as big sagebrush (Artemisia tridentata) shrublands. Wetter adjacent communities may be dominated by inland saltgrass (Distichlis spicata) or willowcottonwood (Salix-Populus species) dominated communities.

Soil-water dynamics within this system support a restricted range of species. Communities in good condition typically have $30-40 \%$ shrub cover. Under continued disturbance, greasewood and western wheatgrass decrease in cover, while species such as foxtail barley (Hordeum jubatum), yarrow (Achillea millefolium), and exotics such as cheatgrass (Bromus tectorum), Japanese brome (Bromus japonicus), and Kentucky bluegrass (Poa pratensis) increase in cover.

\section{Northwestern Great Plains Floodplain System}

This system occurs along the Missouri and its larger tributaries, including parts of the Little Missouri, Milk, Marias, and Saskatchewan rivers (Figure 1.20). These are the big perennial rivers of the region, with hydrologic dynamics largely driven by large amounts of snowmelt and rainfall originating in their headwater watersheds, rather than local precipitation events. In the undisturbed state, periodic flooding of the fluvial and alluvial soils and channel migration create depressions and backwaters that support a mosaic of wetland and riparian vegetation, whose composition and structure is sustained, altered and redistributed by hydrology.
Soils can be Entisols, Inceptisols and Mollisols on older stabilized sites. Often there is up to $1 \mathrm{~m}$ of soil overlying river gravels and cobble. Water tables can drop to $1 \mathrm{~m}$ of the soil surface in summer months. Dominant communities within this system range from floodplain forests to wet meadows to gravel/sand flats, and are linked by underlying soils and flooding regimes. In the western part of the system's range in Montana, the overstory dominant species is black cottonwood (Populus balsamifera ssp. trichocarpa) with narrowleaf cottonwood (Populus angustifolia) and eastern cottonwood (Populus deltoides) occurring as co-dominants in the riparian/floodplain interface near the mountains. Farther east, narrowleaf cottonwood and eastern cottonwood become dominant. In relatively undisturbed stands, willow (Salix species), red-osier dogwood (Cornus sericea), and common chokecherry (Prunus virginiana) form a thick, multi-layered shrub understory, with a mixture of cool and warm season graminoid species below.

In less disturbed occurrences, willow species such as yellow willow (Salix lutea) planeleaf willow (Salix planifolia), peachleaf willow (Salix amygdaloides), common chokecherry (Prunus virginiana), red-osier dogwood (Cornus sericea), serviceberry (Amelanchier alnifolia), and currants (Ribes species) are usually the dominant shrub species. Boxelder (Acer negundo), green ash (Fraxinus pennsylvanica), and American elm (Ulmus americana) are present in some stands. Sandbar willow (Salix exigua) and shrubby cinquefoil (Daisophora fruticosa) frequently colonize recent alluvial bars in central and eastern Montana, while silverberry (Elaaegnus commutata), thinleaf alder (Alnus incana), and Drummond's willow (Salix drummondiana) are colonizers in black cottonwood-dominated floodplains near the mountains and riparian/ floodplain interface. Graminoids associated with these floodplain systems include big bluestem 


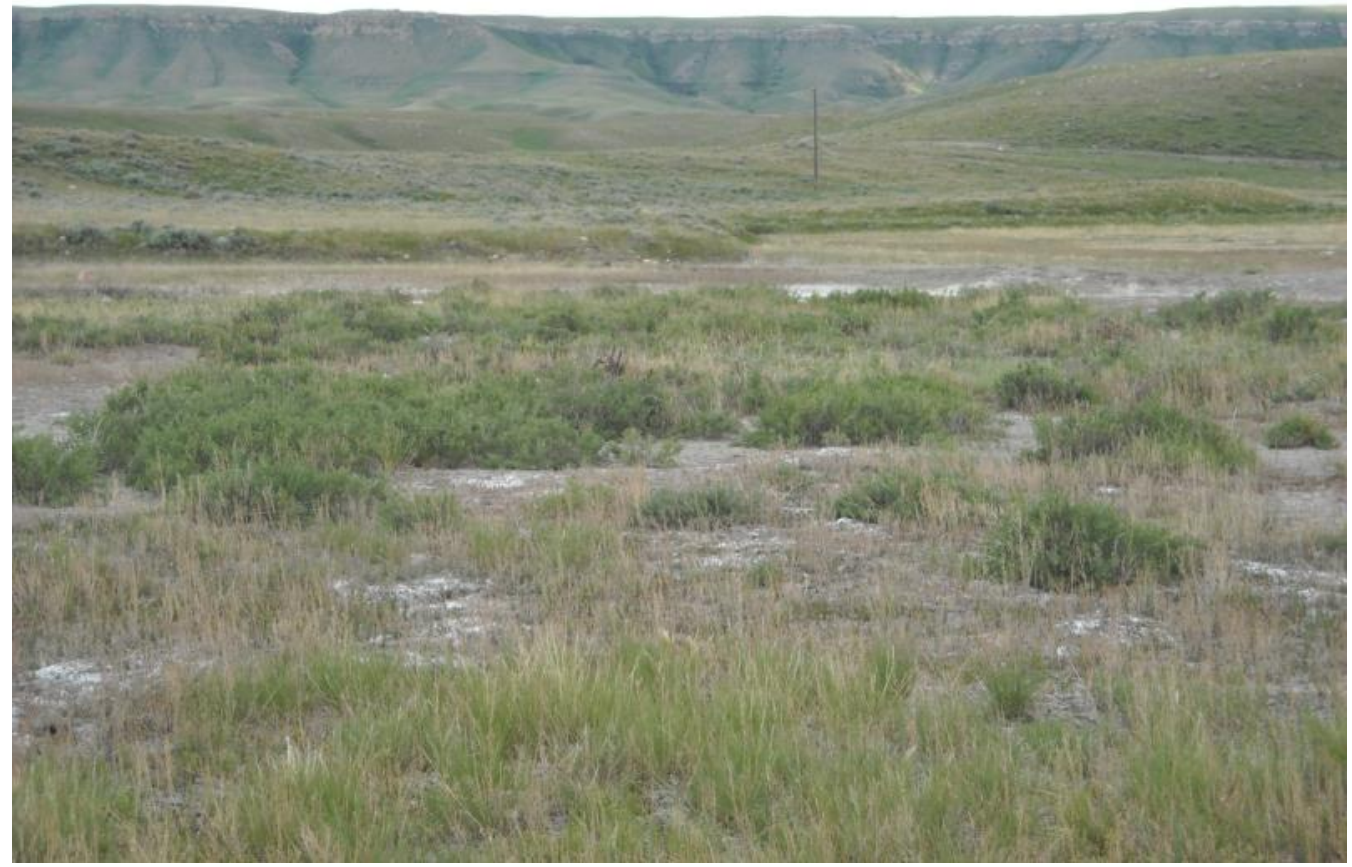

Figure 1.19. Greasewood Flat (Photo K. Newlon)

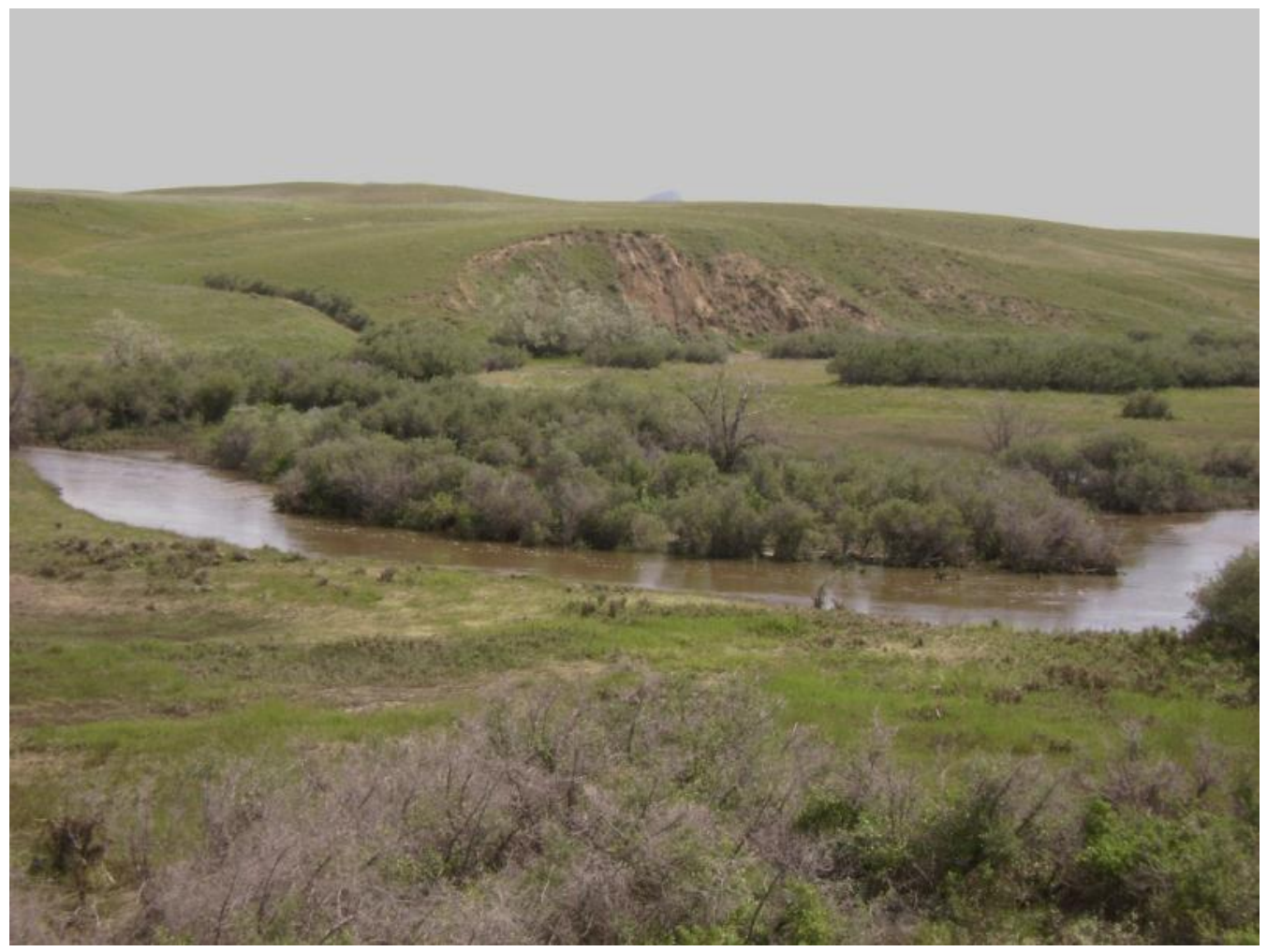

Figure 1.20. Northwestern Great Plains Floodplain (Photo T. Luna) 
(Andropogon gerardii), wooly sedge (Carex pellita), streamside wild rye (Elymus lanceolatus), switch panicgrass (Panicum virgatum), western wheatgrass (Pascopyrum smithii), little bluestem (Schizachyrium scoparium), and sand dropseed (Sporobolus cryptandrus). Forbs include Drummond's dryad (Dryas drummondii), yarrow (Achillea millefolium), starry solomon's seal (Maianthemum stellatum), and aster (Symphyotrichum species).

In Montana, many occurrences are now degraded to the point that the cottonwood overstory is the only remaining natural component. The hydrology of these floodplain systems has been affected by dams, highways, railroads, and agricultural ditches and as a result, they have lost their characteristic wetland/riparian mosaic structure. This has resulted in a highly altered community comprised of relict cottonwood stands with little regeneration. In the system's disturbed/altered hydrological state and/or under heavy grazing pressure, there will be an increase in shrub species such as western snowberry (Symphoricarpos occidentalis) and rose (Rosa species) and a corresponding decrease in willow species, red osier dogwood, currant, serviceberry, and common chokecherry.

Successional processes create a community resembling adjacent upland communities; western snowberry and rose may persist, but will be joined by other native shrubs from adjacent upland communities, such as big sagebrush (Artemisia tridentata). In addition, exotic species such Russian olive (Elaeagnus angustifolia) can invade disturbed floodplain systems, becoming the dominant species. In these disturbed floodplains, the understory vegetation is dominated by a mixture of pasture grasses such as smooth brome (Bromus inermis), common timothy (Phleum pratense), redtop (Agrostis stolonifera), and Kentucky bluegrass (Poa pratensis), as well as non-native forbs such as sweet clover (Melilotus species) and clovers (Trifolium species), Canadian thistle (Cirsium canadensis), and common dandelion (Taraxacum officinale).

Cottonwoods and willows are the dominant tree species in the Northwestern Great Plains Floodplain Systems, creating a highly productive and important habitat type. Since they are specifically adapted to infrequent large flooding events that promote dispersion and colonization of newly formed alluvial bars, management efforts need to begin with identifying the frequency and duration of the flows necessary for colonization to succeed. Northwestern Great Plains floodplain systems have been substantially impacted by the development of both groundwater and surface water for irrigation, isolating rivers from their adjacent floodplains. Unless water management can restore periodic flooding, floodplains and riparian areas may become dominated by late-seral communities, and nutrient cycles may be disrupted without floodwaters depositing organic material. Aggressive non-native Russian olive has drastically altered ecological processes. This species replaces native cottonwood and willow stands where natural flow regimes have been altered. It is especially problematic along the Milk and Marias rivers in eastern Montana.

\section{Northwestern Great Plains Riparian System}

This system is associated with perennial to intermittent or ephemeral streams throughout the northwestern Great Plains. In northern Montana, this system occurs along smaller tributaries of the Missouri River, as well as tributaries to the large floodplain rivers that feed them (Figure 1.21). It is well represented in areas adjacent to the mountain ranges and near the Rocky Mountain Front. This system is found on alluvial soils in highly variable landscape settings, from 


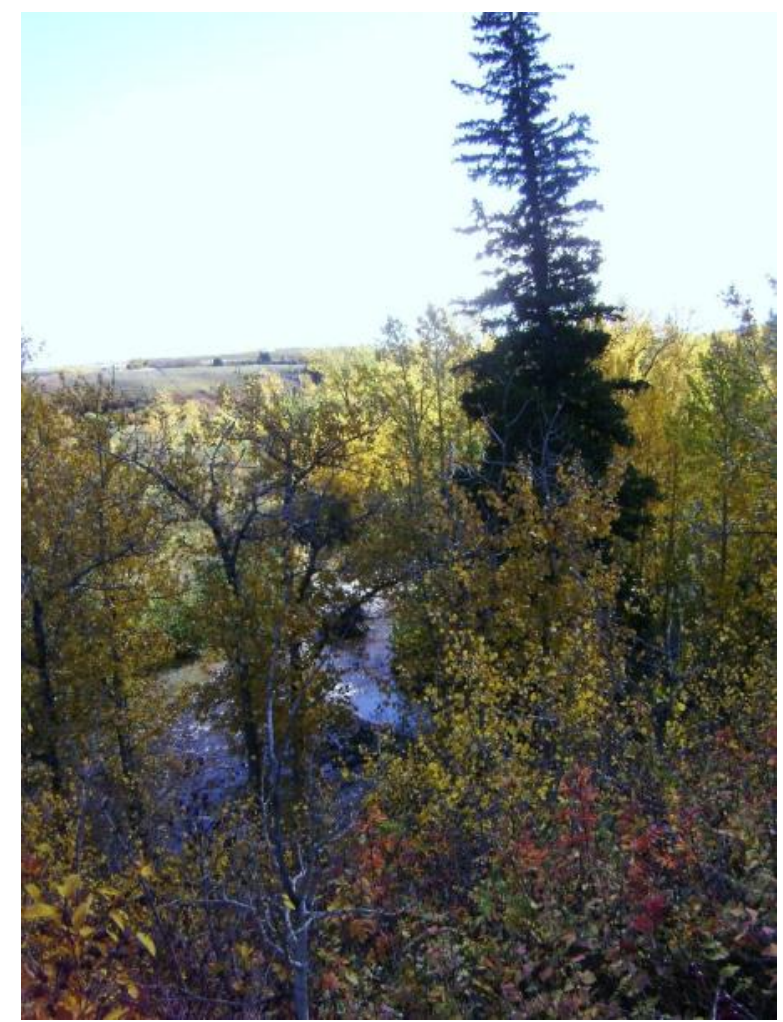

Figure 1.21. Riparian system (Photo T. Luna)

confined, deep cut ravines to wide, braided streambeds. Channel migration occurs in lessconfined areas, but within a more narrow range than would occur in broad, alluvial floodplains.

The primary inputs of water to these systems include groundwater discharge, overland flow, and subsurface interflow from the adjacent upland. In the Great Plains, the water source is primarily local precipitation and groundwater inflow; in systems receiving flow from mountain ranges, snowmelt and summer thunderstorms provide a significant portion of flows. The boundaries of these riparian areas extend beyond the limits of flooding into streamside vegetation. They are important links between terrestrial and aquatic ecosystems, acting as ecotones between upland and wetland, connecting ecological processes and plant communities.
Fluvial processes play a key role in the dynamics of Northwestern Great Plains streams. The nature of these processes is often indicated by channel morphology. Meandering channels generally have a shallow gradient, low flow variability, and sediment loads dominated by silt and finer particles, while braided channels are characterized by a steep gradient, high flow variability, and a sediment load dominated by sand and coarser particles. Flooding is the key ecosystem process. It creates suitable sites for seed germination and seedling establishment, and controls vegetation succession. Communities within this system range from riparian forests and shrublands to tallgrass wet meadows and gravel/ sand flats. Dominant species are similar to those found in the Northwestern Great Plains Floodplain System. Vegetation may be a mosaic of communities that are not always tree or shrub dominated. At lower elevations, forested communities may form galleries dominated by Plains cottonwood (Populus deltoides). Narrowleaf cottonwood (Populus angustifolia) occurs at intermediate elevations and black cottonwood (Populus balsamifera ssp. trichocarpa) tends to be prevalent at higher elevations and near the Rocky Mountain Front. Willows commonly associated with this system include sandbar willow (Salix exigua), yellow willow (Salix lutea), peachleaf willow (Salix amygdaloides), and diamondleaf willow (Salix planifolia). Other shrubs include red-osier dogwood, western snowberry (Symphoricarpos occidentalis), chokecherry (Prunus virginiana), and woods rose (Rosa woodsii). In areas where the channel is incised, the understory may be dominated by big sagebrush (Artemisia tridentata) or silver sagebrush (Artemisia cana).

The herbaceous layer is variable. Subirrigated areas may support tallgrass meadows dominated by big bluestem (Andropogon gerardii) or fresh water cordgrass (Spartina pectinata). Other 
graminoids include wooly sedge (Carex pellita), little bluestem (Schizachyrium scoparium), western wheatgrass, porcupine needlegrass (Hesperostipa spartea), northern dropseed (Sporobolus heterolepis), and panic grass (Panicum virgatum). American licorice and Canada goldenrod (Solidago canadensis) are common understory forbs within all cottonwood riparian systems. These sites are prone to invasion by exotic grasses and forbs, the most widely established being creeping bentgrass (Agrostis stolonifera), cheatgrass (Bromus tectorum), quackgrass (Agropyron repens), Canada thistle (Cirsium arvense), clovers (Melilotus species), leafy spurge (Euphorbia esula), and common dandelion (Taraxacum officinale).

Similar to floodplain systems, riparian systems are often subjected to overgrazing and/or agriculture and can be heavily degraded, with Russian olive replacing native woody vegetation and regrowth. Groundwater depletion, agriculture, and lack of fire have resulted in additional species changes. Furthermore, both channel incision and channel widening have altered flooding regimes, leading to establishment of flood-intolerant species in many areas.

\section{Wetland Plant Community Dynamics}

In the PPR of Montana, many depressional wetlands and marshes are ecologically similar, and frequently contain the same or very similar plant associations. However, they exhibit differences in hydrology. Although much of the water in these wetland systems comes from spring snowmelt, the relationship between the wetlands and groundwater tables is complex and variable on both an annual and inter-annual scale. In turn, a wetland's hydrologic function (recharge, discharge, flowthrough) is determined by variations in climate and by its position in the landscape, the configuration of the associated water table, and the underlying geologic parent material (Euliss et al. 1999). Hydrology defines the hydroperiod, the chemical characteristics of the water, and ultimately the plant communities.

The vast majority of depressional wetlands in this region are categorized as temporary, seasonal, or semi-permanently flooded wetlands. Permanently flooded wetlands, usually larger in size, are less common. Semi-permanent wetlands often have either flow-through, recharge and discharge functions. Temporary wetlands usually recharge groundwater, whereas seasonally flooded wetlands can have either a recharge or flow-through function. Hyper-saline wetlands can exhibit seasonal or temporary flooding regimes, and tend to function mostly as discharge sites. Small, ephemeral wetlands (or vernal pools), typically flooded for only a week or two at snowmelt, are numerous but are not currently classified as wetlands (Cowardin et al. 1979). This variability in hydrology and hydroperiod contributes to the highly dynamic characteristics of wetlands in this region.

The presence of a given plant association or plant community in a particular wetland ecological system is directly related to the hydroperiod, i.e., length of inundation, depth of inundation, or the lack of inundation. Hydroperiod, in turn, is determined by precipitation events, wet-drought cycles, and in many depressional wetland systems, connectivity to ground water. It is also influenced by irrigation runoff or by removal by drainage in agricultural settings. Differences in hydroperiod may result in variability of flora between wetlands within a complex, or within a single wetland at different times,. A depressional wetland, for example, may be dry and dominated by one set of plant communities in the spring, but its floristic composition could change completely if the 
wetland receives substantial rains in early summer and becomes inundated. In another year, the wetland could be dominated by submergents and emergents in spring and early summer, but become dry by mid-summer through evaporation. In this case, annuals that require warm, exposed moist soils will germinate, and perennials adapted to longer periods of draw down become prevalent components of the vegetation during the latter half of the growing season.

Wetland plant communities in the western prairie pothole region are highly dynamic; they change according to water input, deficit, or removal, as well as the presence and longevity of seeds in the seed bank. The dynamic nature of hydroperiod, especially in shallower and ephemeral wetland systems, prevents establishment of species that require longer hydroperiods and water depth in their life history. Extreme annual and seasonal fluctuations in water depth are characteristic of many of the wetland systems in northern Montana. Thus, most dominant species within these communities exhibit life history characteristics that allow them to germinate from dormant seeds, or persist during periods of drought as dormant rhizomes and root systems that are capable of regeneration during favorable periods. To fully assess the plant community dynamics of many depressional systems in this region, plant communities must be described based on the variations in hydroperiod from year to year.

The range of occupation or ecological amplitude of a given species is also influenced by water depth, water chemistry, and soil type. Some species can be dominant or frequent across the range of resource levels. The establishment of a species best adapted to the physical and biological conditions of a site can play an inordinately important role in determining community structure in wetland systems. Some herbaceous wetlands may contain only one or two plant associations, while others may contain more associations that occur along a water depth gradient. Typically, when two or more of these zones are present, one plant association occupies the central, deeper part of the wetland basin, while the others form concentric peripheral bands. Seasonal and annual changes in water chemistry also affect the distribution of plant communities and species diversity (Stewart and Kantrud 1972). Some species can tolerate a range from fresh to saline, but generally, species diversity decreases with increasing salinity. Depending on annual or seasonal hydroperiod and the corresponding changes in water depth and water chemistry, the floristic composition of a wetland can change dramatically from year to year.

Soils and organic matter accumulation also contribute to the structure, spatial pattern, and diversity of plant communities within a wetland system. A species may occupy a range of hydric soils or be restricted to micro-site areas within the wetland with higher accumulation of organic matter. Nebraska sedge (Carex nebrascensis), for example, can occur and be a dominant component of the plant community on a range of soil types, from saturated organic histic soils to silts, clays, silty-clays, and silty-clay loams that are saturated for shorter periods. Woollyfruit sedge (Carex lasiocarpa), on the other hand, is mostly restricted to fully saturated, well developed, organic histic peat soils. Minor species that contribute to the diversity of the wetland flora may be restricted to areas where there are higher levels of organic matter, such as the understory thatch found in hardstem bulrush (Schoenoplectus acutus) dominated communities.

The existing seed bank also plays a large part in the dynamics of wetland communities; it includes all viable seeds present on or within the soil and accumulated litter. Seed banks 
contribute to and maintain genetic diversity at the species level and species diversity at the community level. Contributions are derived from seed rain, which includes dispersal from existing vegetation, but may also include contributions from other wetlands. Waterfowl play an important role in the dispersal of seeds and are especially important for small seeded species (Mueller and van der Valk. 2002; Soons et al 2008).Losses from the soil seed bank generally result from poor germination, predation, decay, physiological death induced by deep burial or drying, death due to seed age, and physical removal due to erosion or other disturbances (Fenner 1992; Leck 1989).

In general, the seeds of species forming seed banks are viable for long periods of time. In wetlands in northern Montana, species that tend to form seed banks are annuals that become established during draw down periods and perennial species that possess dormant seeds. Certain components of the seed bank may be lacking due to dispersal barriers or lack of dispersal agents, short seed life, intolerance to drying and other factors (Weinhold and van der Valk 1989; Galatowitsch and van der Valk 1996; Galatowitsch 2006). Although there are no seed bank studies specific to wetland systems in Montana, some observations by Leck (1989) of freshwater wetland seed banks are applicable. Wetland seed bank diversity is highly variable, and seed bank species diversity and seed quantity may decrease in wetland systems where there is continual inundation. With deeper water and higher salinity, seed bank size and diversity decreases. Species that are adapted to continually saturated or anaerobic soils have seeds that require continual moisture for longevity and persistence, whereas species adapted to seasonal or annual fluctuations in soil moisture possess dormant seeds that can withstand drying. If the wetland has been dry for many years, the seed bank may only contain viable seeds of those species that are adapted to drying (orthodox seeds). Thus, prolonged drought can potentially remove a significant component of the seed bank flora over time. In most wetlands, the majority of viable seeds occur in the upper $4-5 \mathrm{~cm}$ of the soil profile, and therefore, deep seed burial is detrimental for most species.

Most perennial woody and herbaceous wetland species in this region rely heavily on vegetative reproduction as their primary method of reproduction and persistence. During periods of drought, altered or diverted hydrology, or grazing pressure, rhizomes and stolons of herbaceous plants and latent vegetative buds on woody root systems can persist for years in the soil profile. When grazing is removed and the original hydrological regime is restored, there will often be regeneration of rhizomatous species that have been absent or greatly reduced in vegetative cover during the disturbance period. Some herbaceous species can send rhizomes up to $1 \mathrm{~m}$ deep in the soil; these can remain viable for many years. Woody species such as willow (Salix species) possess numerous adventitious vegetative buds on the roots that are capable of breaking bud dormancy and growing into vigorous shoots.

Given these observations, in many wetlands subjected to drawdown periods, seed banks and dormant rhizomes play an important role within the community and are a vital component of restoration efforts. A viable seedbank and remnant stands of rhizomatous perennial species in the soil profile may preclude any further need for revegetation. However, the presence of non-native species within the seed bank can completely change the dynamics of the restored community, and so must be addressed during the restoration planning process.

\section{Summary}

Wetland diversity and variability can be understood in part through classifications schemes like the ecological systems approach. However, the dynamic annual and seasonal changes of 
hydroperiod, water depth, and water chemistry

directly influence the composition, diversity, and spatial distribution of plant communities within a wetland or riparian system. Additions or removals of water and nutrients from irrigation, pumping, or prolonged drought will affect community composition over the long term. These changes in turn may provide a competitive advantage to invasive or non-native species that tend to have broader amplitude to hydroperiod, water depth, water chemistry, and soils than many native species. Seed banks and persistent rhizomes and root systems, soils, and presence of organic matter also affect the spatial distribution, diversity, and composition of the major plant associations within a wetland ecological system. An understanding of the influences that define these systems and the plant associations within them will allow the restoration planner to evaluate the potential for vegetation recovery and recruitment. 


\section{Chapter 2: The Role of Stressors in Ecological Restoration}

In the western Prairie Pothole Region, intensive agricultural and rangeland use, coupled with the prevailing pattern of drought over the past thirty years, have exerted considerable stress on many wetlands. For example, changes in hydrological period due to prolonged drought and/or hydrological alteration, combined with nutrient runoff from adjacent agricultural landscapes, can contribute to the competitive advantage of nonnative species in wetlands. Stressors have a profound effect on the ecological dynamics and recovery of wetland systems. The types of stressors and their level of intensity must be carefully evaluated to predict a wetland's trajectory of ecological recovery. Eliminating or modifying the intensity of anthropogenic stressors is a necessary part of promoting natural system recovery. In modified landscapes and environments, key ecological principles must be fully integrated into restoration project planning.

\section{Stressors in the Western Prairie Pothole Region}

The overriding threat to wetlands in this region is climate change, which affects the diversity, structure, composition, and function of wetland plant communities and the fauna that depend on them. The most apparent manifestations of climate change, precipitation and temperature shifts, exert direct influence of wetland community structure, while also affecting wetland nutrient cycling and water and soil chemistry. Covich et al. (1997) described effects to wetlands due to climate change in the western Great Plains region. Projections show a decline in water levels and in the total number of open water wet basins as a result of temperature increases, even if accompanied with a moderate increase in precipitation. More recent studies show that the Great Plains region in particular will be affected by global warming (NRC 2001, Burkett and Kusler 2000), indicating an increasing trend toward prolonged drought conditions.

Changes affecting spring runoff, such as shifts in the seasonality of precipitation and snow melt, have the greatest potential impact on wetland hydrology and vegetation in this region. Even relatively small changes in water level during dry years may shorten the period of time a wetland contains open water, decreasing habitat for submergent vegetation and increasing the cover and extent of emergent vegetation (Poiani and Johnson 1991, 1993; Poiani et al. 1995). Less open water and submergent vegetation will in turn impact migratory waterfowl and other wetland dependent fauna.

Temporary, seasonal, and semi-permanent wetlands typify the western prairie pothole region. These wetlands contain water for a brief period during spring and early summer months, and become dry during the latter half of the growing season. Shallower wetlands remain completely dry during drought years. With prolonged drought, many temporary or seasonal wetlands in the Western PPR have, lost the hydrology to sustain hydrophytic plant communities, and many are dominated by upland species that colonized these sites from adjacent prairie (McIntyre et al. 2010). Only the presence of relict hydric soils and remnant hydrophyte cover indicates their historic wetland status. Other small seasonally or temporarily flooded wetlands have greatly reduced wetland plant community zonation, often with only one plant association present.

The Prairie Pothole Region has a wetness gradient from east to west, with the driest areas 
occurring in the west. During the twentieth century, this gradient has become more pronounced, with western region of northern Montana has become significantly drier (Johnson et al. 2010). Climate warming simulations project major reductions in water volume and shorter hydroperiods in coming decades, leading to even less dynamic vegetation. Seasonal wetlands are predicted to be most affected by these changes. Thus, a significant percentage of wetlands, particularly in the western prairie pothole region, will be too dry to support historic levels of waterfowl and other wetland dependent species (Johnson et al. 2010).

Another long-term effect of climate change is increasing levels of biogeographic isolation, which is exaggerated in highly modified landscapes, creating even greater recruitment and dispersal barriers between wetlands. Over the long term, this will lead to increasing levels of genetic isolation. It becomes apparent that identifying areas with high wetland density of varying sizes and temporal water availability is critically important for long term conservation and restoration of wetland dependent species in this region. However, wetland complexes constitute only 10 percent of the total depressional wetland acreage in the region. Wetland complexes occurring within natural rangeland landscapes possess the largest buffer zones and have the greatest potential for system recovery, function, and persistence. Geographically isolated wetlands are common in this region, accounting for 23 percent of the total depressional system acreage in the Milk-Marias-St. Mary River basins (McIntyre et al. 2010). Isolated wetlands in good ecological condition contribute significantly as biological links between wetland complexes for gene dispersal, diversity, and adaptation, and thus are important as satellite biological refugia. Other threats to hydrological function include anthropogenic stressors; these threats are widespread in other regions of the Great Plains. In the United States, $98 \%$ of all wetland loss has been from freshwater wetlands (Dahl 2000), such as those found in the western prairie pothole region. Many of the shallower wetlands in the western region have been hayed, excavated, or highly modified, especially those found within agricultural settings. Fertilizer, insecticide, and herbicide runoff from adjacent agricultural cropland, when coupled with the lack of a natural buffer zone, seriously compromises the natural successional processes and biological integrity of the wetland.

Oil and gas development has been and will continue to be another stressor on wetlands in this region (Figure 2.1). In 1996, the United States and adjacent Canadian provinces of the prairie pothole region produced nearly 16,000,000 barrels of oil annually (Leitch and Fridgen 1998). The Williston Basin of Montana, North Dakota, and South Dakota has been developed for over fifty years, with extensive new oil and gas development associated within the Bakken Formation, which is found across the prairie pothole region. At least 292,745 wetlands occur within a $1.6 \mathrm{~km}$ reach of oil and gas development in the prairie pothole region (Preston et al. 2012), with critical breeding and nesting habitat for a large proportion of North American migratory waterfowl.

Oil and gas extraction poses a threat of ground disturbance to wetlands and their buffers, as well as risks of surface, ground water and soil contamination through hydro-fracture drilling (also called "fracking"), spills and above ground storage of fracture fluids. In addition, there are excessive water resource demands associated with this drilling method, which may tax already stressed groundwater and surface water resources. Over 3 million gallons of water are 


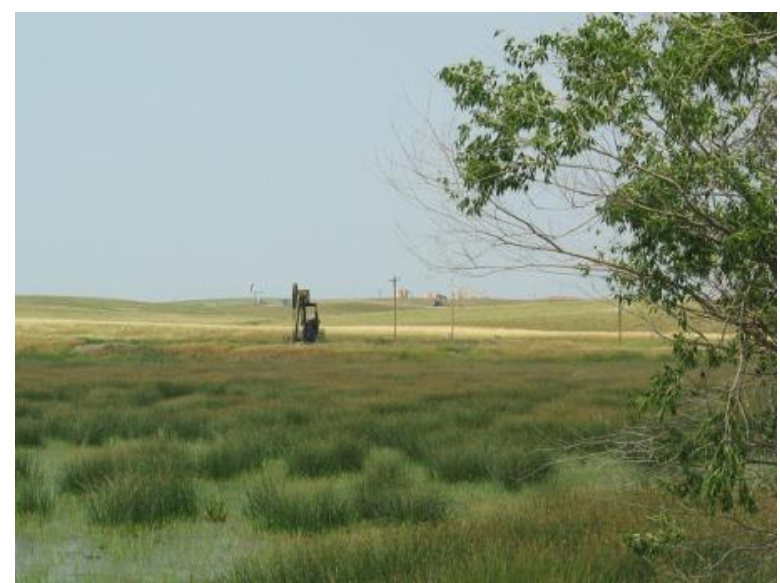

Figure 2.1 Oil and gas development, Sheridan County (Photo L. Vance)

needed to drill an average well in the Bakken Formation (Preston et al. 2012).

Soil surface integrity and water quality are important indicators of wetland condition, and can be used to evaluate the potential for ecological recovery once stressors are removed or modified. Prolonged, intensive cattle use is one of the most common anthropogenic stressors to wetlands in this region. Excessive cattle use contributes to the alteration of hydrology, hydric soil compaction, decreased soil surface stability, and destruction and degradation of wetland vegetation. Intensive nutrient loading by cattle can degrade water quality and contribute to algal blooms that collapse wetland flora and fauna (Figure 2.2). As with agricultural fertilizer runoff, excessive nutrient loading by cattle, combined with ground disturbance, can contribute to the competitive advantage of exotic plant species.

Sedimentation of depressional wetlands is common within agricultural and rangeland landscapes, and in particularly impacted areas, wetlands can lose most or all of their original volume (Hong-Ren et al 1997). Shallow wetlands with temporary or seasonal flooding regimes are especially vulnerable to sedimentation, resulting in burial of seed and invertebrate egg banks. As little as $0.5 \mathrm{~cm}$ of sediment can eliminate 91 and 99 percent of seedling and invertebrate emergence (Gleason et al 2003). Sediment deposition also has serious implications for the highly dynamic wetland margin. Adequate buffer margins, composed of native prairie, can greatly reduce sedimentation rates. Greater buffer lengths may be needed for wetlands occurring adjacent to coarse to medium textured agricultural soils.

The lack of a natural buffer zone or natural vegetation buffer connectivity to other wetlands can also seriously limit the potential for recovery of water quality, hydrology, precipitation catchment and recharge, and dispersal and recruitment of wetland vegetation. Optimal natural buffer width may vary with wetland type and condition of the natural surrounding landscape. Adequate buffer zones and adjoining natural landscapes typically support wetlands that can be restored to function, diversity, and integrity with the least management intensive methods. Natural landscapes and buffer zones serve many important purposes for wetland integrity, including precipitation catchment and release, moderation

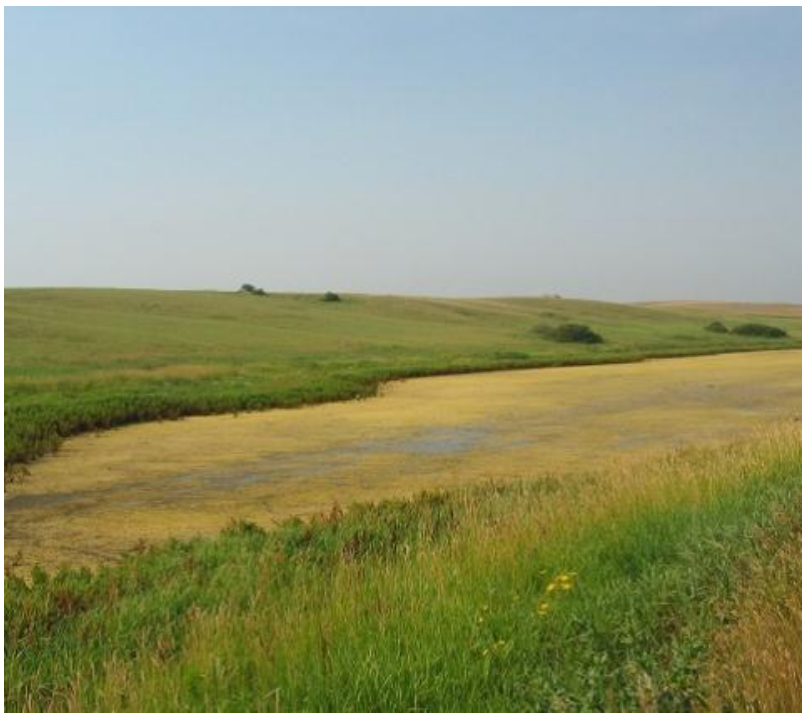

Figure 2.2. Algal bloom caused by excessive nutrients (Photo L. Vance) 
of water temperature, improved or optimal water quality through catchment of agricultural chemicals, nutrient storage and release, and contributions of organic matter (Figure 2.3).

When restoring wetlands in agricultural landscapes, the original height and structure of the adjacent original plant community also has to be restored or maintained to the greatest degree possible. Most of the wetlands in this region are surrounded by mixed grass prairie. Dominant species typically have an average stem height of 6$35 \mathrm{~cm}$. If farmland restoration plantings are prescribed in surrounding buffer zones adjacent to wetlands, they should use species with the same maturity heights found in native mixed grass prairie communities.

Bioinvasion by exotic species is associated with climate change and other anthropogenic disturbances. Established stands of highly aggressive species can seriously limit potential for full ecological recovery. The ecological effect extends beyond detrimental changes to community diversity and structure. Exotic species within or even adjacent to wetland complexes lead to disruptions to water catchment and changes in hydroperiod, as well as changes in nutrient cycling. Many exotic species have deleterious effects on wetland ecosystem structure, composition and function. The relative density of aggressive exotic species plays a significant role in the feasibility of restoring a wetland. For example, many shallower depressional wetlands and marshes in the PPR have been invaded by reed canarygrass (Phalaris arundinacea) and common reed (Phragmites australis). Both species are highly adaptable and capable of tolerating a range of environmental conditions. Both are superior competitors, especially when nutrient additions from agricultural runoff are present. These species outcompete other wetland graminoids, even cattail, due to their tall stature, rapid growth, rapid canopy closure and tolerance to changes in water input (Wetzel and van der Valk 1998). These species can

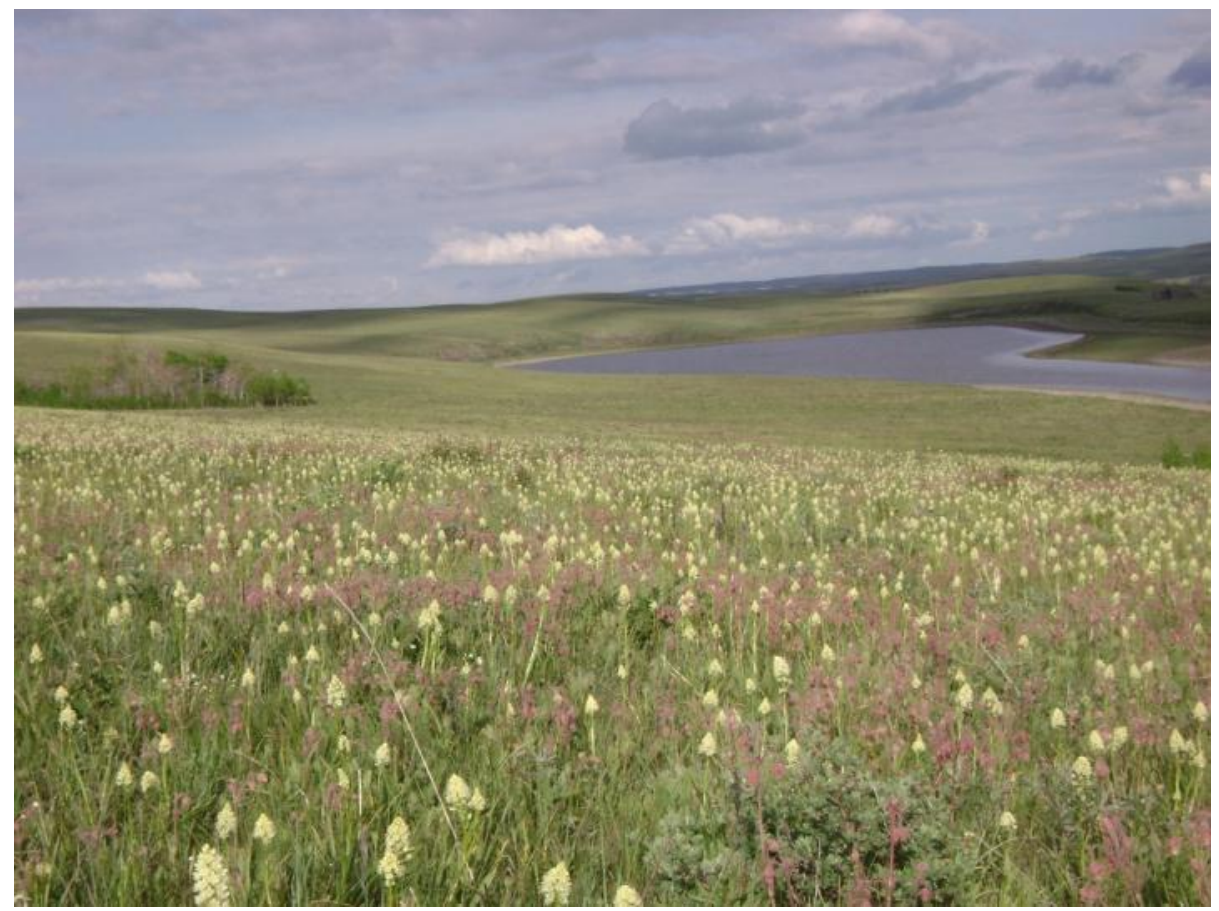

Figure 2.3. Buffered wetland (Photo T. Luna) 
become monocultures in disturbed wetlands, in a relatively short period of time, completely eliminating the native wetland flora and reducing plant community structure to one monotypic layer. Dense stands alter evapo-transpirational patterns, contributing to altered or shortened hydroperiods. The change in biomass and the frequency in which it enters to detrital food web alters nutrient cycling patterns.

Eurasian strains of common reed can hybridize with North American subspecies, adding a genetic competitive advantage over native wetland vegetation (Meyerson et al 2010). Differences among genetic lineages of this species may result in greater physiological adaption to environmental variables (Mozdzer and Zieman 2010). Similar phenomena may occur among native and introduced lineages of reed canarygrass. Rapid growth following seed germination and establishment (Reinhardt and Galatowitsch 2005) and morphological variation among strains may play a significant role in competitive advantage of reed canarygrass, especially in disturbed and newly restored wetlands (Herr-Turoff and Zedler 2007).

Many introduced pasture grasses can invade a range of dry to wet meadows and wetland edges. Under continual disturbance and nutrient loading, these species can become established easily, decreasing native plant diversity and creating highly altered plant communities. The widespread use of exotic grasses such as smooth brome (Bromus inermis) for wildlife conservation plantings can significantly change the hydrodynamics of depressional wetlands. In farmlands planted to smooth brome, springtime snowmelt runoff from the surrounding hills can be hindered by the tall, persistent stems of the conservation plantings in the adjacent buffer zone (van der Kamp et al. 1999). As wetlands continue to dry through combined effects of climate change, land use disturbances, and altered buffer zones, exotic species will present an ever greater challenge for restoring wetland integrity.

Damming and stream alteration are the most obvious stressors on floodplain riparian systems in the Prairie Pothole Region. Diversion of water by dams, highways, railroads and agricultural ditches limits cottonwood recruitment. Dams reduce flood magnitude and frequency, rates of sedimentation, and channel migration. Regeneration of cottonwood depends on these processes. On the Milk River, seedling recruitment is severely limited below the Fresno Dam in Montana when compared to upstream stands in Alberta (Bradley and Smith 1986). The result is a highly altered community comprised of relict cottonwood stands with little or no regeneration.

The task of restoring a wetland complex requires the restoration planner to address all stressors, evaluating the degree of stressor impact, and the relationships among them to formulate ecologically sound and realistic restoration goals and objectives. All the work, cost, and effort associated with a restoration project can be negated if adjacent land management practices are not concurrently modified. In many cases, modifying adjacent land use practices is the simplest and most cost effective means of restoring wetland function.

\section{Applying Ecological Principles to Restoration Planning Efforts}

The Society for Ecological Restoration (2004), Young and others (2005) and Zedler (2000) address several key ecological principles and ecosystem attributes that should be fully integrated into wetland restoration efforts. These principles and attributes provide ecological guidelines for formulating restoration goals and objectives, which in turn define the necessary management actions required to restore a system 
to its proper level of function. They include:

\section{1) Landscape position and context are crucial to wetland restoration.}

Wetland function is closely related to landscape position, so alteration of landscapes constrains wetland restoration. Many depressional wetlands occur as wetland complexes. Future restoration efforts should concentrate on restoring complexes of wetlands to maximize the potential for increasing biodiversity and proper function (Galatowitsch et al. 1998). In the northern Great Plains, function and ecological integrity of prairie potholes and other depressional wetlands is closely correlated with the adjacent uplands. Wetlands that occur within adjacent croplands exhibit more alterations to hydrology, including drainage ditches and greater erosion (Guntenspergen et al. 2002), which in turn contributes additional chemical and biological stresses to wetland function. Appropriate natural buffer width and buffer connectivity are crucial in restoring wetland integrity and function.

\section{2) Natural habitats are the most useful reference sites in formulating restoration objectives.}

Undisturbed wetlands should be used as a reference standard for determining the range of plant communities capable of colonizing or regenerating within a restoration site. Reference sites are the foundation of understanding ecosystem function and the range of plant communities capable of persisting on a site. A reference network of sites reflecting a range of disturbance levels can provide information on disturbance response and successional trends; they are invaluable in predicting restoration trajectories. Because wetlands in this region are highly dynamic, multiple reference standard sites should be visited, using a space-for-time substitution that enables planners to determine the range of plant communities that would occur and change according to water input and depth from year to year.

\section{3) Restored wetlands should contain a characteristic assemblage of native species that occur in similar reference sites.}

These assemblages provide characteristic community structure for a particular wetland system and include all native life forms. All functional groups (or life forms) of the plant communities should be represented or have the potential to recruit naturally into the restoration site; thus, they can contribute to the continued successional development and stability of the wetland. Each wetland and riparian restoration site must be thoroughly evaluated for its potential for species recruitment from nearby wetlands. If key life forms or functional groups are missing or have little potential for recruitment, the restoration site has a higher likelihood of invasion by aggressive non-native species.

\section{4) It is important that native species are well represented in the restored wetland to the greatest extent possible, and that the restoration site has high potential to interact with other wetlands through abiotic and biotic interactions.}

This requires an assessment of the health and condition of the buffer zones, wetland complex, adjacent landscapes, and their potential influences on the restoration site. Reducing or modifying stressors to the extent possible from within the wetland, associated wetland complex, and the adjacent landscape is necessary to restore proper ecological function.

5) The specific hydrological regime of a given wetland ecological system is crucial to restoring biodiversity and function.

Partial improvements may assist in restoring wetland function and biodiversity. Hydrological 
regimes differ not only in frequency and magnitude, but also in duration, timing, and temporal sequences of water depth or lack of water. Restoring system hydrology and predicting how it may change due to stressors is essential when formulating long term restoration plans.

\section{6) Ecosystem attributes develop at different paces.}

Many important wetland ecosystem functions are promoted by organic matter accumulation and intact, relatively undisturbed recent litter layers including the maintenance of food web chains and cycling of water and nutrients. Organic matter accumulation can be slow in restored wetlands, even though high cover of natural vegetation has been achieved (Shaffer and Ernst 1999). Restored wetlands exhibiting some level of organic matter accumulation exhibit much greater potential for short term ecological recovery than. Newly created wetlands, which rarely have the same characteristics and functional attributes as natural wetland systems. It will take many decades for newly created wetlands to develop this crucial ecosystem function.

\section{7) Nutrient supply and rates affect biodiversity recovery.}

Nutrients can greatly affect restoration efforts. Elevated levels of nitrogen or agricultural chemicals from the surrounding landscape can determine what species will recruit and persist in the altered wetland environment. Many of the wetlands in Montana's western prairie pothole region have unique and variable water chemistry that directly influences the vegetation communities present. If adjacent agricultural chemical runoff or nutrient loading by cattle cannot be altered, the restoration planner must adjust restoration objectives and the predicted trajectory of plant community recovery. In these cases, recovery of native vegetation may be limited to a few highly tolerant and adaptable species that can persist in the presence of altered water quality and highly aggressive non-native species.

\section{8) Specific disturbance regimes can increase species richness.}

Moderate levels of disturbance may increase species richness, contributing to the mosaic of patch types and biodiversity found within a wetland. How disturbance contributes to diversity must be thoroughly documented for each wetland system and the species it contains. Here, a network of reference sites can help determine the point at which a disturbance creates a negative impact on the community. However, and the outcome will always depend in part on the plant communities already present on the restoration site.

\section{9) Seed banks and dispersal can limit species richness and recovery.}

Seeds of major wetland species in northern Montana exhibit a wide range of dispersal mechanisms, longevity characteristics, and germination requirements. These factors can constrain recruitment or establishment into restored wetlands. The existing seed bank may contain a suite of native species that can germinate during the next inundation phase, but prolonged drought can eliminate species from the seedbank if they require moist soil conditions to remain viable. The ability of seeds to recruit into a site depends on distance between wetlands and the condition of dispersal sources. If a wetland that is actively being restored is surrounded by wetlands where propagules do not reach maturity because of heavy grazing practices or lack of visitation by dispersal agents such as birds, the potential for recruitment will be lower.

Wetland plant species rely on suitable flooding conditions for a long enough period of time to fulfill their life-history requirements (germination, establishment, growth and reproduction), or they 
must have the capacity to persist as dormant seeds or vegetative propagules long enough to germinate and establish or re-establish during the next inundation phase. Proximity to other wetlands and the condition and disturbance factors of these propagule sources can influence species recruitment and diversity of the restored wetland.

\section{0) Environmental history and life history traits must be addressed when restoring biodiversity.}

Constraints on dispersal or seed availability decrease the likelihood of species recruitment even when hydrological regimes are restored. In both restored prairie potholes and riverine marshes, some species may fail to recruit into the site, especially those that are dispersal limited, rare, or a minor component of the plant community (Galatowitsch and van der Valk 1996; Galatowitsch 2006; Seabloom and Van der Valk 2003). Depending on the life history and environmental constraints favoring species assemblages on a site, the site may recover its full range of biodiversity over the long term. However, revegetation efforts may be required on some sites to meet short-term restoration objectives or to establish key dominant species that are currently missing and show little potential for natural recruitment.

\section{1) Successional theory and application must be integrated in formulating restoration planning and goals.}

Ecological succession is the process by which the component species of a community change over time. Following a disturbance, an ecosystem generally progresses from a simple level of organization (i.e., few dominant species) to a more complex community (i.e., many interdependent species) over several generations. In many ecological systems, communities tend to recover following mild to moderate natural and anthropogenic disturbances, and restoration involves a hastening of natural successional trajectories. However, a system that has experienced a more severe disturbance (i.e., physical or chemical alteration of the environment) may require more intensive restoration efforts to recreate environmental conditions that favor natural successional processes.

\section{2) The physical environment of the restoration site must be capable of sustaining reproducing populations.}

All abiotic factors that influence and shape the wetland system must be restored to support healthy, reproducing biological communities. This in turn allows the restored wetland to be resilient or adaptable to periodic stress, and contributes to its potential to persist over time. Physical and chemical characteristics of the restoration site influence the species that regenerate, recruit, or are planted, as well as the trajectory of successional processes. Failed revegetation plantings in wetland and riparian restoration projects usually can be traced to species being planted into soils and hydrological conditions that do not favor or support their growth. Thus, systematic efforts should be made in each wetland to define plant community trajectories over time and to eliminate the possibility of introducing species into areas that will not support community survival and growth.

\section{3) Presence and dominance of exotic species plays a key role in community dynamics.}

Many non-native, invasive plant species possess characteristics that allow them to out-compete native species for resources, often capitalizing on disturbance. The adjacent transitional plant communities buffering the wetland are important in maintaining proper ecological function, and adjacent land use can significantly impact function and structure of plant communities (DeKeyser et al. 2009). Many prairie potholes and adjacent 
low prairie plant communities have been planted to exotic grasses such as Kentucky bluegrass ( $\mathrm{Poa}$ pratensis) and smooth brome (Bromus inermis) to provide dense nesting cover for waterfowl; these species can invade pothole and depressional wetlands during dry years, producing unfavorable wetland conditions for rearing (van der Kamp et al. 1999; Voldseth et al. 2007). The life history and ecology of each non-native plant species present within and adjacent to the restoration site must be thoroughly evaluated. These characteristics will help determine restoration suitability and weed management actions. Contributions of exotic species to the wetland seed bank, and their persistent rhizomes and root masses, must also be addressed.

\section{4) Genotypes influence ecosystem structure and function.}

Genetic differences among ecotypes or seed sources of a species have been shown to affect restoration outcomes. In the past, restoration practices have emphasized the use of local genotypes as propagule sources. However, in highly fragmented landscapes, propagules should be collected from a broader geographic range or from as many locations as possible, including the edges of preferred habitats and the edges of geographic ranges. Populations of a given species that are healthy, reproducing, and occupying these wetland complexes may exhibit greater genetic diversity and thus can contribute even greater potential for adaptability to environmental changes.

\section{Summary}

The types and intensity of stressors are major factors in determining wetland health and condition. Ability to eliminate stressors or mute their impact is a determinant in evaluating a site's suitability for restoration and the degree of recovery that can realistically be expected there over time. All of a wetland system's ecological processes and environmental and biological influences must be thoroughly assessed when considering restoration efforts, as each factor will help formulate rational and ecologically sound restoration goals and objectives for chosen sites. Identifying areas with high densities of wetlands in good condition, or with the fewest or most reversible stressors, will promote long-term conservation efforts in the Western Prairie Pothole Region. 


\section{Chapter 3: Assessing Restoration Suitability}

Not all wetlands are suitable candidates for restoration. For example, in many wetlands, wetland hydrology has been lost due to drainage or diversions that cannot be reversed. Similarly, excavation, filling, or ditching may have caused irreparable damage to, or loss of, wetland soils. In other cases, conversion of surrounding landscapes to intense human land uses may have altered the flux of sediment, nutrients and contaminants into the wetland to the degree that wetland function will always be compromised. Still other wetlands have been so invaded by exotic species or noxious weeds that the level of mechanical and chemical effort needed to remove unwanted vegetation makes restoration too costly or too impractical.

These clearly unsuitable restoration candidates are easy to identify. What is more challenging, however, is identification of sites that offer the greatest potential for success. In this chapter, we offer guidance for determining whether a specific wetland is a suitable candidate for restoration, and assessing its current departure from reference standard.

\section{Criteria for Restoration Suitability}

We suggest that there are five basic selection criteria, derived from the ecological principles discussed in the previous chapter, which should be followed to increase the likelihood of restoration success for wetlands in the Prairie Pothole Region. A wetland is likely to be a good candidates for restoration if:

1. the wetland is part of a wetland complex;
2. the wetland is embedded in a relatively unaltered landscape where stressors can be controlled by the land managers involved in the restoration;

3. the hydrology of the wetland complex is undisturbed, or if disturbed, can be restored to its full functioning condition;

4. soils in the target wetland and surrounding upland buffers are undisturbed, or if disturbed, can be remediated; and

5. vegetation in the wetland and the surrounding upland buffers is dominated by species native to the area.

Wetland complexes. In the PPR, wetland restoration decisions have often been driven by waterfowl habitat considerations or by landowner desires to achieve specific water management objectives (e.g., ponds for livestock) or to qualify for government incentives. Such specific goals often dictate site-based restoration, rather than a larger watershed approach. However, Prairie Pothole Region wetlands occurred historically in diverse complexes, with a mix of sizes, hydroperiod, and characteristic plant communities, all contributing to the maintenance of biological diversity (Galatowitsch et al. 1998). If restored wetlands are to have the compositional and structural characteristics, the functionality, and the persistence of historical wetlands, it follows that they will need to draw on the same biotic and abiotic relationships that those historical wetlands enjoyed. Therefore, when prioritizing wetlands for restoration, wetlands occurring as part of a wetland complex should be selected before those that have been isolated by human activities, unless connectivity to a complex can be restored.

Landscape alteration and stressors. Particularly in the eastern US, where intense human land 
uses often drive the processes that determine wetland condition and sustainability, landscapelevel suitability screening has become increasingly common in wetland restoration (White and Fennessey 2005). In the Western PPR, which is still largely dominated by rangeland and low-intensity agriculture, it is easy to overlook the steady increase in energy development, transportation networks, and human population centers, and their associated impacts on ground and surface water, wildlife populations, and plant communities. Long-term persistence of restored wetlands will depend in large part on the maintenance of ecological processes in the site itself and in the surrounding landscape (Herrick et al. 2006). Therefore, restoration site selection should take both current and future landscape-level disturbances into account. This, in turn, means that the most suitable sites will be located where land managers involved in the restoration have some control over adjacent and nearby land uses.

Undisturbed or restorable hydrology. It is wellestablished that hydrology is the most important driver of wetland establishment, processes, and functions (Mitsch and Gosselink 2007). Therefore, any potential restoration site needs to be assessed for its hydrologic suitability. In cases where hydrology has been altered, the key question will be whether suitable supply and timing of water can be restored, along with connections to groundwater and surface water sources. In some cases, this may mean that water rights will need to be secured prior to beginning restoration. We emphasize that evaluations of wetland hydrology need to occur at the complex level, not only at the specific wetland site. If water is being pumped from wetlands in upstream parts of the complex, groundwater connectivity with the targeted restoration site may be compromised. Similarly, if other wetlands in the complex are subject to draining or ditching, the complex as a whole may not support all life history stages of wetlanddependent species.
Undisturbed or remediable soils. Pugging, hummocking, compaction, or erosion of wetland soils can alter plant-water relationships within the wetland. Similarly, loss of soil integrity in upland areas can lead to excessive sedimentation in the wetland. In some cases, addition of fill material (either intentionally, as in the case of dumping of dredging spoils, or unintentionally, through deposition of river-borne sediments) may mean that soils are historically hydric, with non-hydric layers above layers that still have hydric indicators. An assessment of the hydric status of soils is important in wetland restoration, as the presence of hydric soils (even relict hydric soils) may be a prerequisite for restoration funding under different federal programs. Generally speaking, removal of fill material and restoration of wetland hydrology will be sufficient, over time, to restore hydric soils. However, microbial activity associated with hydric soils may be greatly diminished in historically hydric or relict hydric soils, slowing the restoration trajectory for the whole wetland. Therefore, choosing restoration sites with undisturbed or minimally disturbed soils in both the wetland and upland buffer will increase the chances of success.

Presence of native vegetation. Even if all other selection criteria are satisfied, wetland restoration may run aground if the wetland and surrounding uplands are dominated by non-native species, as may be the case in areas where exotic grasses and legumes have been planted to provide dense nesting cover (DNC) for birds (Reynolds et al. 2001). DNC species selected for their vigor are likely to be opportunistic colonizers of bare ground, and their tall stature, long season growth and density may alter surface runoff into wetlands. Furthermore, DNC may require periodic management treatments such as grazing, haying or burning to maintain desired heights, introducing additional stressors into the restoration area (Devries and Armstrong, 2011). If noxious weeds 
are present in and around the potential restoration site, the likelihood of successful eradication and long-term control needs to be evaluated before proceeding to site selection, paying special attention to species that benefit from moist soil conditions, e.g., common tansy (Tanacetum vulgare), field bindweed (Convolvulus arvensis), leafy spurge (Euphorbia esula), purple loosestrife (Lythrum salicaria), whitetop (Cardaria draba) and yellow toadflax (Linaria vulgaris). Conversely, if nearby wetlands and uplands are well-vegetated with locally adapted native species, they can be a source for seeds, cuttings, and natural colonization.

\section{Tools for Assessing Sites and}

\section{Restoration Areas}

Once basic site selection criteria have been considered, the restoration planner may be faced with a set of potential restoration sites needing prioritization. One of the most effective and economical methods of screening wetlands for restoration is a region-specific, qualitative and quantitative wetland assessment. Several assessment protocols are available. Protocols in wide use in Montana range from rapid assessments of Proper Functioning Condition (Pritchard, 2003) to the Montana Department of Transportation's Montana Wetland Assessment Method for highway projects (Berglund and McEldowney 2008) to Army Corps of Engineers' Hydrogeomorphic (HGM) Method for Prairie Potholes (Gilbert et al. 2006). Over the past several years, the Montana Natural Heritage Program (MTNHP) has been refining a protocol for assessing the ecological integrity of wetlands, using the three-tiered approach recommended by the U.S. Environmental Protection Agency: 1) a landscape-level assessment using GIS; 2) a rapid, semi-quantitative multimetric field assessment of wetland condition; and 3) a quantitative, vegetation-based method used to calculate indices of biological integrity. This protocol, which has been tested extensively in the western PPR, offers restoration professionals a detailed methodology for evaluating the degree to which the candidate wetland's condition departs from reference standard wetlands in the region. Although we do not claim that this protocol is superior to the others mentioned here, we think that it offers a balance between extremely rapid methods such as PFC and the detailed functional characterization required by the HGM approach. The MTNHP method ${ }^{1}$ will be the focus of the remainder of this Chapter.

\section{The Three-Tier Approach to Assessing Wetland Function and Integrity}

In MTNHP's approach, the first tier (Level 1) is a GIS analyses that uses readily available digital datasets and aerial photo inspection to generate 1) wetland landscape profiles, summarizing information on wetland abundance, type, extent, and function within a given basin or watershed; and 2) a landscape characterization, identifying anthropogenic stressors around individual wetlands, e.g., roads, human land uses like agriculture or grazing evidence, etc. The Level 2 assessments provide rapid, field-based evaluations of wetland condition, based on indicators of landscape context and buffer integrity, hydrology, soils, and vegetation, as well as nearby stressors. . Finally, Level 3 intensive assessments collect detailed information on the structure and composition of wetland vegetation. With this multi-tiered framework planners can integrate landscape-level information with measures of ambient wetland condition and site-specific data (Newlon 2012).

Level 1 assessment and profiling. Figures 3.1 and 3.2 provide examples of landscape profiles maps for the Milk, Marias, and Saint Mary river basins (McIntyre et al. 2011). The Level 1 GIS analysis in the MTNHP approach can also be used in conjunction with historical wetland mapping to

1. The Protocol and forms can be downloaded from http://mtnhp.org/wetlands/docs/Protocol.pdf 


\section{The Milk, Marias, and Saint Mary Rivers}

Sixth-code Hydrologic Units

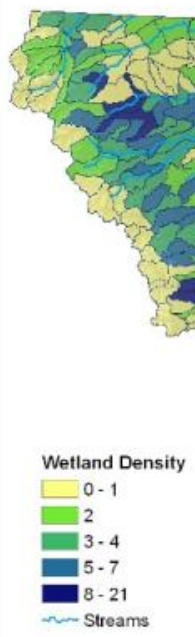

Figure 3.1. Level 1 landscape profile of wetland density by subwatershed (from McIntyre et al. 2011)

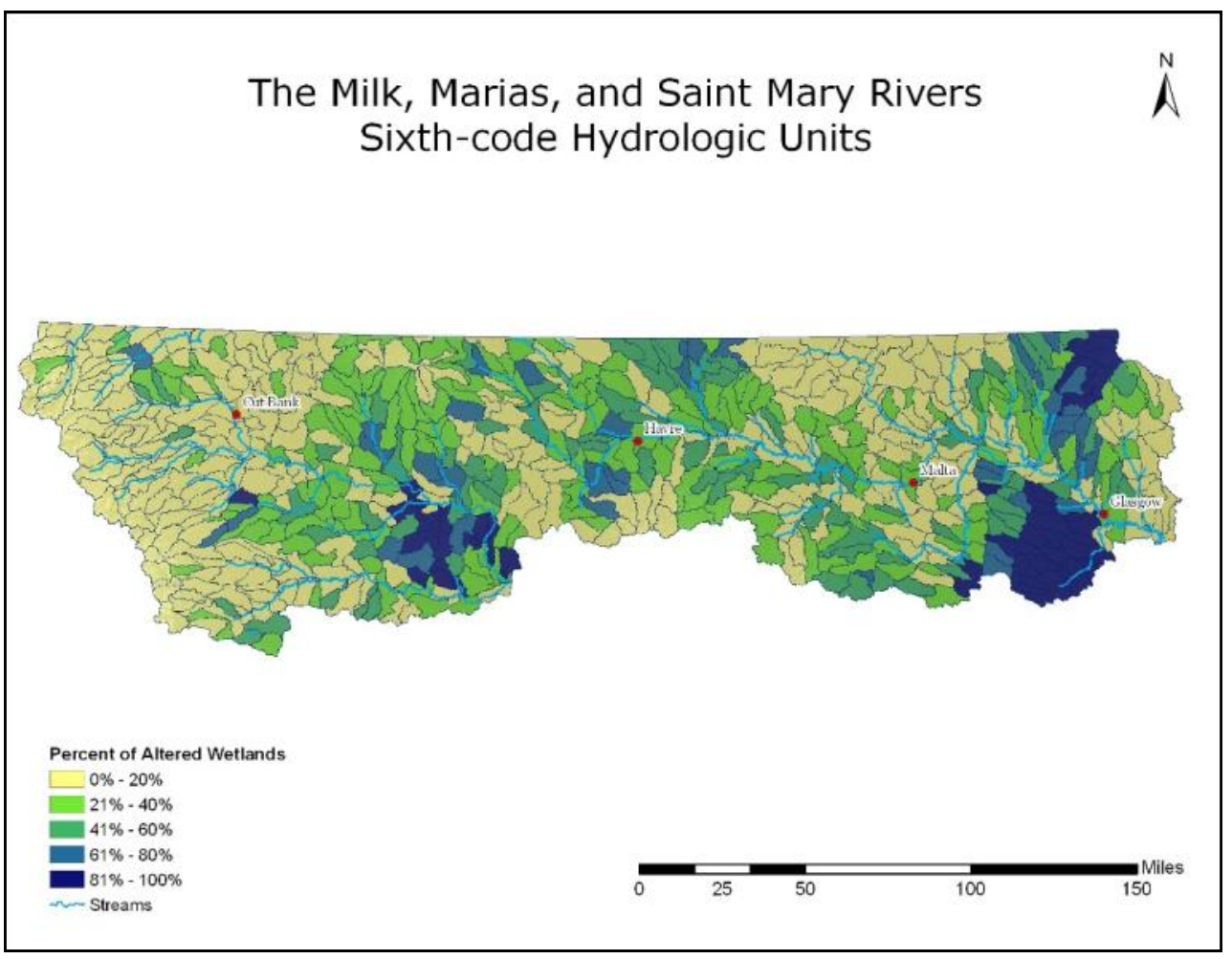

Figure 3.2. Level 1 landscape profile of wetland alteration by subwatershed (from McIntyre et al. 2011) 
to determine whether there has been wetland loss or conversion within a basin (Stein et al. 2010), or with ancillary climate layers (historical or projected) to assist restoration decision making and planning (Vance 2009). Additional metrics can be calculated to assess habitat suitability. For example, perimeter to area ratio can be measured for each wetland polygons as an indicator of the wetland's ability to provide habitat for interior-dependent and/or edge-dwelling species (Helzer and Jelinski 1999). Similarly, connectivity among wetlands can be evaluated by calculating distances to nearby wetlands (Gibbs 1993).

Level 2 assessment. The second tier (Level 2) is a rapid ( $\sim$ two hours) assessment conducted in the field. Field methods for are detailed in the Montana Ecological Integrity Assessment Field Manual (MTNHP 2010b). At each wetland point, an assessment area (AA) is established for sampling. Readily observable ecological criteria such as vegetation, soil, and hydrological characteristics are used to define wetland boundaries. Because certain field metrics vary by Ecological System, crews attempt to include only one Ecological System in the AA. For example, if a given wetland has both a wet meadow component and a riparian shrubland component, the AA would typically be located in one or the other, but would not span both.

The Level 2 method is based on a suite of metrics used to evaluate the major attributes affecting wetland integrity and function, including landscape position, landscape buffer, hydrology, soils, and existing vegetation (Table 1). Each attribute is scored on a number of metrics, each described by a specific narrative statement that represents the known range of its possible state, as based on visual indicators. These are used to arrive at an average wetland integrity score. It is important to note that indicators for wetland condition vary depending on wetland type. During the Level 2 assessment, stressors affecting
Table 2. Level 2 attributes and metrics

\begin{tabular}{|c|c|}
\hline Attribute & Metric \\
\hline \multicolumn{2}{|l|}{ Landscape } \\
\hline \multirow[t]{5}{*}{ Context } & Landscape Connectivity \\
\hline & Buffer Width \\
\hline & Buffer Length \\
\hline & Buffer Condition \\
\hline & Relative Cover of Native Plant \\
\hline \multirow[t]{9}{*}{ Vegetation } & Species \\
\hline & Relative Cover of Tolerant \\
\hline & Native Plant Species \\
\hline & Relative Cover of Noxious \\
\hline & Plant Species \\
\hline & $\begin{array}{l}\text { Herbaceous Litter/Woody De- } \\
\text { bris Accumulation }\end{array}$ \\
\hline & Interspersion of Plant Zones \\
\hline & $\begin{array}{l}\text { Woody Species Establishment } \\
\text { and Regeneration }\end{array}$ \\
\hline & Utilization of Trees and Shrubs \\
\hline \multirow[t]{2}{*}{$\begin{array}{l}\text { Physico- } \\
\text { chemical }\end{array}$} & Soil Surface Integrity \\
\hline & $\begin{array}{l}\text { Water Quality: Algae, Plants, } \\
\text { and Turbidity }\end{array}$ \\
\hline \multirow[t]{4}{*}{ Hydrology } & Water Inputs \\
\hline & Water Outlets \\
\hline & Hydroperiod \\
\hline & Surface Water Connectivity \\
\hline
\end{tabular}

wetland health are evaluated and described, using a checklist of observed stressors or disturbances commonly found in Montana wetlands (Table 2). Stressor lists can provide additional information when evaluating ecological integrity and help link observed condition to factors that may have to be addressed in restoration. In some cases, stressors may be present at or near a site, but condition metrics may not yet reflect their impacts. This may be due to a temporal lag between the impact and its effect on the biotic community, such as a very recent powerline cut. While applying the checklist to stressor occurrence, the scope and severity of each stressor is also estimated (FaberLangendoen et al. 2011; Table 3). Scope is defined as the proportion of the occurrence of an ecosystem 
Table 2. Stressor metrics and associated disturbance categories.

\begin{tabular}{|c|c|}
\hline Transportation Disturbances & Land Use Disturbances-Vegetation Removal \\
\hline $\begin{array}{l}\text { Paved surfaces (e.g., roads, parking lots) } \\
\text { Unpaved roads } \\
\text { Railroads }\end{array}$ & $\begin{array}{l}\text { Chemical vegetation control } \\
\text { Evidence of intentional burning } \\
\text { Vegetation conversion }\end{array}$ \\
\hline Land Use Disturbances-Development or Recreation & Natural or Environmental Disturbances \\
\hline $\begin{array}{l}\text { Domestic or commercial development } \\
\text { Intensively managed sports fields, golf courses } \\
\text { Recreation or human visitation } \\
\text { Filling or dumping of sediment or fill } \\
\text { Trash or refuse dumping }\end{array}$ & $\begin{array}{l}\text { Beetle-killed Pinus species } \\
\text { Other diseased conifers } \\
\text { Evidence of recent fire ( }<5 \text { years) } \\
\text { Beaver activity } \\
\text { Evidence of prolonged drought } \\
\text { Browsing of woody vegetation by native ungulates }\end{array}$ \\
\hline Hydrologic Disturbances & Land Use Disturbances-Agriculture \\
\hline $\begin{array}{l}\text { Upstream spring box } \\
\text { Impoundment of flowing water } \\
\text { Potential for agricultural runoff } \\
\text { Potential for urban runoff } \\
\text { Upstream dam } \\
\text { Reservoir/stock pond } \\
\text { Weir or drop structure } \\
\text { Dredged inlet/outlet channel } \\
\text { Engineered channel (e.g., riprap) }\end{array}$ & $\begin{array}{l}\text { Dryland farming } \\
\text { Livestock grazing } \\
\text { Irrigated cropland } \\
\text { Irrigated hay pasture } \\
\text { Permanent tree plantation } \\
\text { Disturbed fallow lands dominated by exotic species } \\
\text { Haying of native grassland } \\
\text { Fallow fields (no human use in past } 10 \text { years) } \\
\text { Plowing or discing }\end{array}$ \\
\hline $\begin{array}{l}\text { Pumps, diversions, or ditches that move water into wet- } \\
\text { land }\end{array}$ & Land Use Disturbances-Resource Extraction \\
\hline $\begin{array}{l}\text { Pumps, diversions, or ditches that move water out of } \\
\text { wetland } \\
\text { Berms/Dikes/Levees }\end{array}$ & $\begin{array}{l}\text { Gravel pits, open pit mining } \\
\text { Other mining activity or abandoned mines } \\
\text { Resource extraction (oil and gas) } \\
\text { Intensive logging ( } 50-75 \% \text { trees of }>50 \mathrm{~cm} \text { diameter } \\
\text { removed) } \\
\text { Selective logging ( }<50 \% \text { of trees }>50 \mathrm{~cm} \text { diameter } \\
\text { removed) }\end{array}$ \\
\hline
\end{tabular}


Table 3. Scope and severity ratings for stressors observed within the assessment area (AA) and within a 200-m envelope around the AA.

\begin{tabular}{|ll}
\hline $\begin{array}{l}\text { Score } \\
5\end{array}$ & Scope of Disturbances \\
4 & Large - Affects most $(>50-75 \%)$ of the envelope or AA. \\
3 & Moderate - Affects much $(>25-50 \%)$ of the envelope or AA. \\
2 & Restricted - Affects some $(>10-25 \%)$ of the envelope or AA. \\
1 & Small - Affects a small $(1-10 \%)$ portion of the envelope or AA. \\
0 & Nil - Little or no observed effect $(<1 \%)$ on the envelope or AA. \\
Score & $\quad$ Severity of Disturbances \\
4 & Extreme - likely to extremely modify, degrade, destroy, or eliminate the wetland. \\
3 & Serious - likely to seriously modify, degrade or reduce wetland function or condition. \\
2 & Moderate - likely to moderately modify, degrade or reduce wetland function or condition. \\
1 & Slight - likely to only slightly modify, degrade, or reduce wetland function or condition.
\end{tabular}

that can reasonably be expected to be affected by the stress. Severity is the level of damage to the site from the stressor that can reasonably be expected with continuation of current circumstances. Stressor scope and severity scores are rolled up into an overall stressor impact score (Appendix C)

Level 3 assessment. The Level 3 assessment is used to describe composition of existing vegetation, which can indicate relative levels of disturbance and degradation to the wetland system as well as the level of restoration effort that will be required. Field methods for Level 3 assessments are detailed in the Montana Ecological Integrity Assessment Field Manual (MTNHP 2010b). Vegetation data is collected using a $20 \mathrm{~m}$ x $50 \mathrm{~m}$ relevé plot (Peet et al. 1998). The plot consists of ten $10 \mathrm{~m} \times 10 \mathrm{~m}\left(100 \mathrm{~m}^{2}\right)$ modules typically arranged in a $2 \mathrm{~m} \times 5 \mathrm{~m}$ array (Figure 3.3), subjectively placed within the AA to maximize abiotic/biotic heterogeneity. Capturing heterogeneity within the plot ensures adequate representation of local variations produced by hummocks, water tracks, fluctuating water levels or differences in water table depth, or by wetland edge and microtopography, etc.

Four intensive modules are selected, and a complete species list is made for each, with absolute cover estimated for each species. When all species within a module have been identified, the remaining, or residual, modules are walked to document presence of any species not recorded in 
the intensive modules, and percent cover of these species is estimated over the entire $1,000 \mathrm{~m}^{2}$ plot. If the wetland is particularly diverse, more than one $20 \mathrm{~m}$ x $50 \mathrm{~m}$ relevé plot can be used. For example, if a wetland consists of both woody and herbaceous dominated communities, two series of plots can be established to describe the communities present.

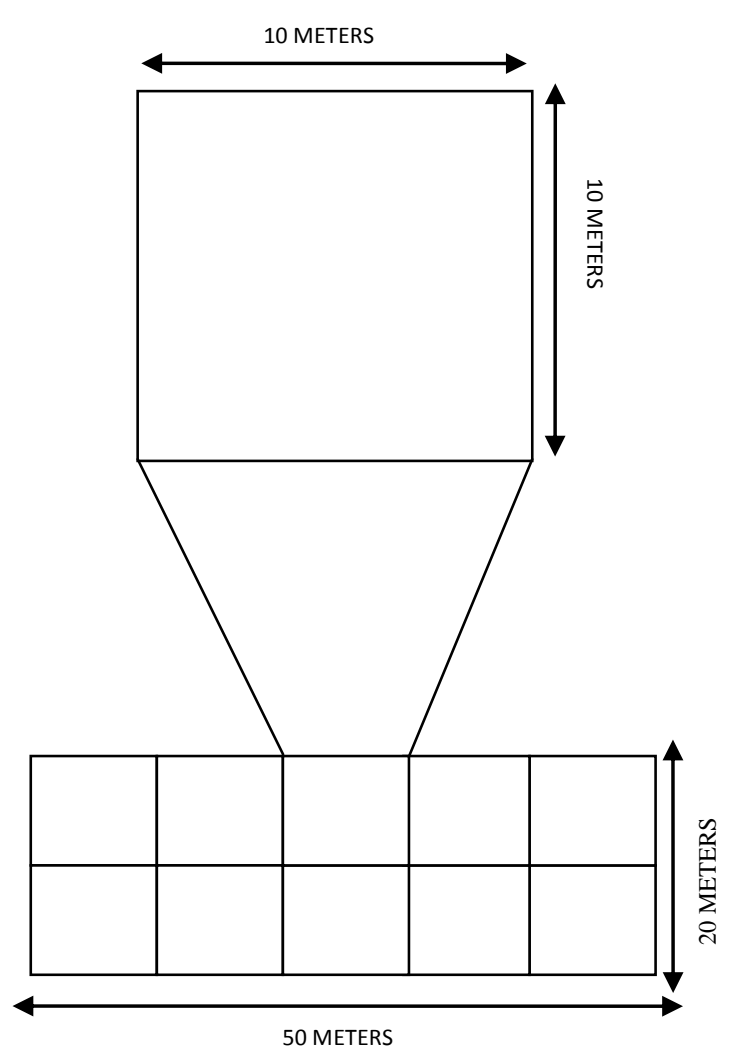

Figure 3.3. Relevé plot layout (adapted from Peet et al. 1998)

Plot data forms the basis for the calculation of metrics (See Appendix D) needed in a floristic quality assessment (FQA). Coefficients of conservatism (C-values) are assigned to taxa identified to species; these $\mathrm{C}$-values represent the relative tolerance of a species to disturbance, ranging from 0 to 10 (after Andreas et al. 2004). Native species that exhibit high degrees of ecological specificity and sensitivity to disturbance have C-values of 9-10. Native species that are typical of well-established communities that have undergone minimal disturbance have $\mathrm{C}$-values of 6 -8. Native species that have some degree of habitat specificity but can tolerate moderate disturbance have C-values of 3-5. Widespread native species that occur in a variety of communities and are common in disturbed sites have values of 1-2. Finally, exotic species are assigned C-values of 0 . While plant species composition varies across the growing season, and between years, the distribution of C-values and derived FQA metrics should remain the same in the absence of disturbance. However,. FQA scores have proven to be very responsive to anthropogenic change when it occurs (Cronk and Fennessy 2001, Miller and Wardrop 2006). With their known sensitivity, FQA values can be used as a baseline for monitoring post-restoration improvement, or to compare performance of a restoration wetland to a nearby reference site.

\section{Summary}

Not all wetlands are equal in terms of their suitability for restoration. Optimum suitability occurs when the target wetland is part of a wetland complex; when it is embedded in a landscape where stressors are minimal or manageable; when hydrology of the wetland complex is undisturbed or restorable; when soils in the target wetland and surrounding upland buffers are undisturbed, or if disturbed, can be remediated; and when vegetation in the wetland and the surrounding upland buffers is dominated by species native to the area.

Prior to beginning a restoration, potential restoration wetlands should be thoroughly assessed, using well-tested methods. The three tiered method can be used as an effective tool for planning watershed scale as well as smaller scale restoration projects. At the coarse scale, GIS 
analysis can identify concentrations of wetlands for conservation and restoration, based on wildlife migration patterns as well as future climate and regional land use profiles. In the field, broad indicators of condition can be collected rapidly, and intensive vegetation plots can yield precise information about impacts from stressors. Taken together, results from all three levels of wetland assessment can be reviewed to prioritize wetlands for restoration and management, and to formulate land management plans that will protect wetland ecological integrity. Wetland sites that are rated in excellent to very good ecological condition can be identified as conservation sites, and can be utilized as reference sites for restoration of other wetlands, while impacted sites can be prioritized for restoration work. 


\section{Chapter 4: Restoration Project Planning}

Defining project objectives is a key element in restoration planning. Objectives, in the broad sense, are to restore the ecological function of the site, the associated wetland complex, and an upland buffer, and to facilitate conditions that contribute to the greatest potential for ecological recovery. Ecological reference sites are crucial to restoration project planning; they provide the basis for predicting the trajectory of natural system recovery. Aerial imagery, ground water table maps, land contour maps, and soil maps can be used to define changes between historical and current conditions. Typically, a restoration project plan includes steps for restoring hydrological function and cultivating soil conditions that favor native wetland plant regeneration and growth within the site and, as much as possible, the natural condition of the adjacent buffer zone and surrounding landscape as well.

Interannual variations in establishment success, also known as 'year effects,' have been a persistent problem for restoration planners, who often have only a single planting year to achieve their project goals. "Year effects" also influence natural events such as periodicity in seed production and natural seedling recruitment, establishment or regeneration. Restoration planning will require precise timing when particular environmental conditions are likely to affect restoration practices. For example, planning should incorporate forecast trends for climate events such as El Nino and La Nina. Post restoration management practices, such as grazing, burning and weed treatments can also be directly dependent on year effects, and may be more effective if timed appropriately.

Restoring vegetation in a wetland can be largely accomplished by relying on an existing seed bank, natural dispersal, recruitment, and regeneration. Certain species occurring within or near the restoration site have the potential to regenerate or recruit following other restoration activities. Predicting the extent to which vegetation will regenerate is based on species life history traits and post restoration conditions in the wetland. The planner must assess the condition of existing native vegetation, existing weed sources, and --if time and resources allow-- the seed and rhizome bank. From this, the planner can project future vegetation conditions and recovery and potential for restored wetland function over time.

The level of planning required for a restoration project will depend on project size, land ownership, timeframe, and financial constraints. Even for small wetland restoration projects, though, careful planning can prevent costly mistakes and optimize site recovery and restored ecological function. Regardless, planning and documenting all restoration actions will provide invaluable information for future projects under similar site conditions and stresses.

\section{Ecological Reference Sites}

Reference sites are the foundation of restoration project planning. They provide an ecological reference or model for restored ecological function and potential vegetation following restoration actions. They also serve as a reference point in time for potential outcomes Equally as important, they provide a baseline measurement for post-restoration monitoring and evaluation. Suitable reference sites are those that are ecologically similar to the restoration site, and are recovering from similar disturbances. Undisturbed sites, or those that are in excellent ecological condition, are important for projecting potential long-term recovery of the site. Using a range of 
reference sites will assist the restoration planner in developing ecologically appropriate restoration management actions.

It can be difficult to locate a pristine, undisturbed wetland system that has not been impacted by human activity. However, if these reference sites are located, the restoration planner can use information from them to indicate the long-term potential for recovery of the restored wetland. Once the hydrology, soils, condition and width of the buffer zone, and other environmental factors have been characterized, the planner will have a thorough understanding of the components required for optimal ecological function. How the relatively undisturbed reference site is responding to current stresses such as prolonged drought should be documented and described in detail. Surveys of reference sites must include a comprehensive species list, a description of the major plant associations that constitute the wetland vegetation, an analysis of possible successional trends, and an assessment of the hydrology, water quality, soils, and organic matter accumulation at the site.

The site's present condition, species composition, and extent of adjacent buffer zones must be assessed because they affect wetland system recovery and function. In depressional systems, the low prairie surrounding the wetland should be included in assessments to capture annual shifts or vegetation trends between upland and wetland community boundaries that change due to fluctuating water levels. The assessment process should also document encroachment of upland vegetation in wetlands subjected to prolonged periods of drought (DeKeyser et al. 2003). For depressional wetlands, it is important to emphasize that any given reference site should be assessed over a number of years to account for annual variations in hydroperiod.

Using a series of reference sites with stressors of different types and intensities provides a more comprehensive understanding of the dynamics of vegetation recovery over time. The best reference sites for predicting short-term outcomes from restoration activities will be sites that have recovered from disturbances similar to those at the restoration site. The stage of recovery is important. For example, project planners can use several reference sites that represent recent disturbance over time and intensity gradients. Disturbed reference sites can be chosen to represent disturbance from 2 to 10 years, and at greater increments, if possible. Types of disturbance within and adjacent to a reference site should be accurately defined and evaluated for their level of impact on the site. Disturbed reference sites indicate the range of successional processes in conjunction with disturbance types. These reference sites will help establish what steps and site conditions are necessary to facilitate successional processes at the restoration site.

Recovering, persistent, and colonizing vegetation must be assessed and mapped. Wetland land use history should be thoroughly investigated by obtaining information from land management agencies or land owners. A synthesis of data from the disturbed and undisturbed reference sites will inform ecologically appropriate and realistic restoration objectives.

It is important to emphasize that reference sites that exhibit less than desirable outcomes following restoration activities are equally important. Examples are those that exhibit weed infestation; failed hydrological function; lack of native vegetation; succession to cattail, common reed or reed canary grass dominated communities; failed revegetation plantings; or revegetation efforts with non-native species. Visually inspecting former restoration projects that have failed to restore function also can be quite useful in planning a restoration project with similar environmental and biological conditions. 
The vegetation of the restoration site and reference sites can be described and mapped with vegetation plots (Figure 4.1). Vegetation plots will define the range of cover of dominant species and all other species present in the area. Recording and mapping physical patch types present within the wetland will describe the plant community structure and complexity. Patch types such as open water, mudflats, and floating mats perform important ecological functions and can be important indicators of wetland function.

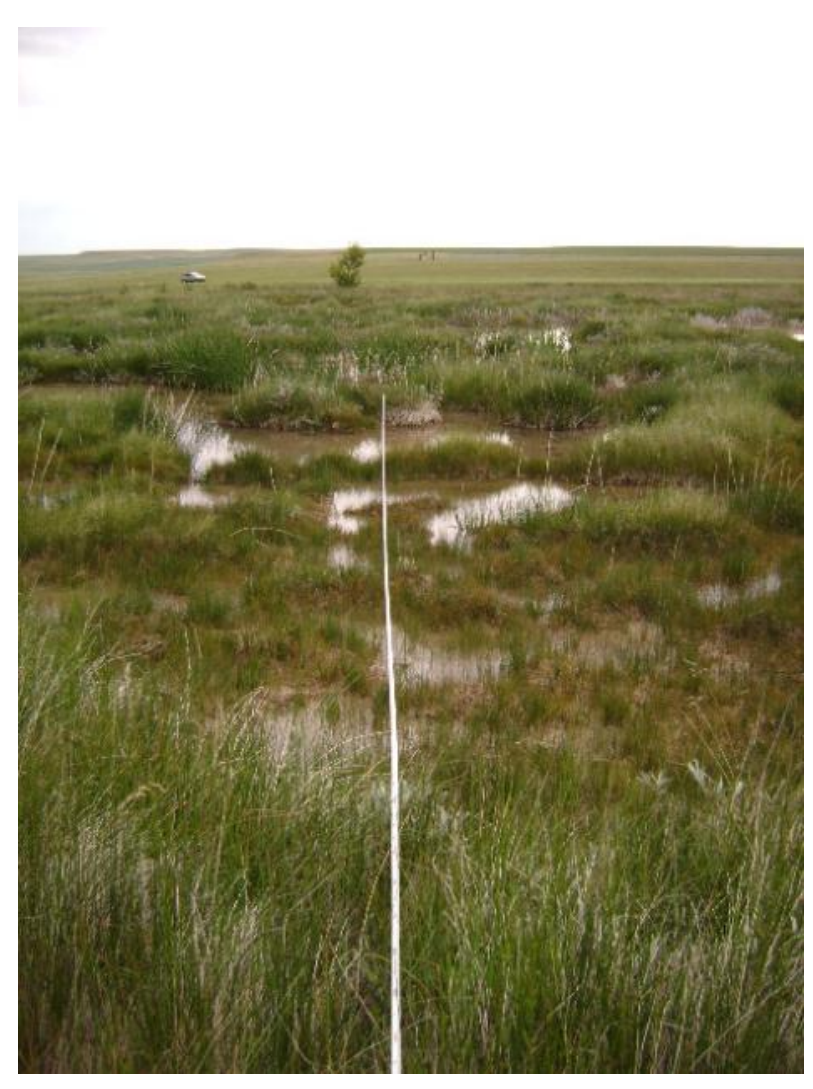

Figure 4.1. Laying out a vegetation plot transect (Photo T. Luna)

\section{Maps and Aerial Imagery}

Aerial imagery and maps are useful planning tools in targeting wetlands for restoration on a watershed scale (Russell et al. 1997, McIntyre et al. 2011), especially when they are available in digital form and can be used within a GIS. They are particularly useful in identifying the adequacy of buffer zones surrounding wetlands, adjacent land uses, hydrology of the watershed, relative wetness, vegetation, influencing geology, and spatial proximity to other wetlands. For restoration

planning, this information can be used in conjunction with other data layers such as original topographic relief of the area and groundwater table location. They can also be used to define changes between historical and current conditions.

Groundwater table maps, where they exist, can provide an overview of the hydrological dynamics

and influences of the restoration site and the relationship to any interconnecting or associated wetlands. Topographic quad maps are useful for site visits and can be obtained from the U.S. Geological Survey, while Digital Elevation Maps (DEMs) are useful for defining basins. National Wetland Inventory (NWI) maps from the 1980s can assist the planner in determining the location and extent of complexes, even when some wetlands within the complex have been altered or lost over the past thirty years. Excellent cadastral and transportation GIS data, plus land cover and land use classifications, are available as part of the Montana Spatial Data Infrastructure, and, can be incorporated into a GIS with topographic data and soil maps. These soil maps can be used as a planning aid; however, they should not be used as a substitute for examining and mapping soil samples at the restoration site.

\section{Defining Restoration Project Objectives}

Well defined objectives are necessary for project planning and actions. Objectives are usually determined in a broad sense for specific actions 
required to restore the ecological function of the site and facilitate those conditions that will contribute to the greatest potential for ecological recovery. Definitive project objectives are needed early in project development. Once these objectives are determined, all necessary restoration actions can be planned, scheduled, and implemented on an appropriate, coordinated timeframe.

For example, a general restoration goal would be "to facilitate all processes that will allow for the natural recovery of the wetland and adjacent buffer zone." Restoration objectives to attain this goal would include all necessary components for restoring ecological function of the wetland and, to the greatest extent possible, elimination or alteration of all stressors to system recovery. As an example, a set of objectives might include:

- Restore site hydrology to the greatest extent possible;

- Improve and enhance the upland buffer to promote water quality, and soil surface stability;

- Allow for recruitment, establishment and recovery of native vegetation;

- Protect and encourage existing wildlife use.

Clearly stated restoration objectives simplify the task of determining necessary management actions. For the objectives listed above, a planner might pursue the following activities:

- Remove existing drainage ditch and irrigation pump from wetland;

- Identify and modify all other water removal sources from connecting ground water table;

- Establish a natural vegetation buffer zone within a minimum of 500 meters around the wetland perimeter to allow for natural precipitation catchment, runoff, and recharge of the wetland from adjacent landscape, emphasizing vegetation similar in composition and height structure to historical mixed grass prairie;

- Implement deferred grazing regime for a minimum of 5 years to facilitate regeneration and spread of remnant perennial hydrophytic vegetation, and to improve water quality and soil surface stability by minimizing nutrient loading by livestock;

- Control two known existing Canadian thistle populations in restoration site and continue to manage this species for at least 5 years following restoration.

- Sample and monitor invertebrate populations to assess population recovery, species richness and availability of food sources for waterfowl.

\section{Developing the Restoration Plan}

During a project's initial planning phases, all key players involved in the restoration and management of the site should also play a role in site evaluation. All persons involved in restoration activities must have a thorough understanding of how timelines, methods, and other factors can potentially impact restoration project objectives. This includes contractors involved in restoring hydrology, equipment operators, soil scientists, ecologists, wildlife biologists, weed managers, livestock managers, and other specialists. Scheduling a field day to provide an overview of the project site is useful for everyone involved and can potentially eliminate problems that could impair results of the project. It can also be a time to formulate and coordinate initial, coherent timelines for restoration activities and land management practices.

Restoration planning requires a thorough assessment of the site's ecology and the relationship of the site to the connecting wetland complex. This will require defining, describing, and mapping areas within the site that differ based on the range of plant associations, soils, hydrology, and topographic position. For each area, the planner must define differences between mapped areas... This will allow the planner to predict vegetation response following other restoration activities. It will also define potential problem areas that may be vulnerable to weed invasion, soil erosion, sedimentation, or other undesired effects. After the working restoration 
map and plan have been assembled, the planner must carefully evaluate the potential limiting factors in each delineated area of the restoration site. This final step can help define additional actions that may be required to reach restoration goals. By defining the projected future conditions of a restoration site, the planner can identify appropriate restoration actions that will facilitate ecological recovery. Defined future conditions can establish monitoring criteria that can be used to predict and measure restoration outcomes. It can also specify the desired vegetation composition at a point in time following restoration activities.

Defining future conditions provides a baseline prediction to measure natural system recovery. This must be formulated from restoration and reference site assessments and seed bank tests. For example, a defined future condition for an open depressional wetland complex could be:

"Five years following all restoration actions (including restoring hydrology, deferred grazing for a minimum of 5 years, and prerestoration weed treatments), vegetation cover will be composed of hardstem bulrush, white water crowfoot, common spike rush, Nebraska sedge, Baltic rush, and western wheatgrass dominated associations. Native annual species such as needle spikerush, mouse-tail, and alkali buttercup are expected to be a significant component (at least 20\% cover) of the plant community in drawdown zones during the latter half of the growing season. The restoration site will be composed of 50\% native vegetation and $30 \%$ open water. The site will be managed as needed to control Canada thistle for a minimum of 5 years following restoration."

\section{Identifying the Limiting Factors of the Project Site}

Limiting environmental and biological factors can be defined as any conditions that limit or exceed the tolerance and adaptation of an individual species or plant community. Identifying the limiting factors for each plant community within the restoration site is an essential process because it recognizes those factors that may prevent or negate proposed restoration activities. Two or more factors may be equally important and interrelated, such as soil compaction and alteration of surface hydrology caused by intensive cattle use. Prerestoration management activities may be needed to significantly reduce or eliminate conditions that are most limiting to the reestablishment of the natural functioning of the ecological system and native vegetation. Other limiting factors can include isolation, water input or availability, water quality, adjacent land use, an intensively farmed or over-grazed watershed, lack of native buffer, poor ecological condition of the surrounding landscape, lack of organic matter accumulation, excessive siltation in the basin, lack of native seed banks, lack of remnant native hydrophytic vegetation, presence of weeds, and the likelihood of intensive development nearby. Other limiting factors include stressors that generally cannot be altered or managed, such as adjacent roads.

One of the most significant limiting factors to restoration in this region is water availability and water input. The seasonality and hydroperiod of a wetland will largely determine the extent to which a wetland can be restored to an acceptable state of ecological condition and functionality. For wetland and riparian areas that exhibit impaired hydrological function and/or water chemistry, corrective measures can be taken to restore system hydrology. These are addressed in more detail in Chapter 5, Restoring Hydrology.

Water quality at the restoration site should be assessed by collecting samples, preferably several times through the growing season, and ideally over a period of two or more years. Samples should be thoroughly analyzed by a laboratory to identify the types and concentrations of dissolved salts, total salinity, individual toxic ions, nitrogen and 
phosphorus additions, and the presence of possible agrichemical contamination. Initial water quality sampling is also a valuable planning aide in predicting species composition and vegetation recovery, whether through natural regeneration and recruitment, or through reseeding or planting of native species adapted to the range of water quality parameters. Because species composition is directly affected by water quality; species can be limited or eliminated by one or more water quality attributes.

Soil condition can be an important limiting factor if there has been significant damage or erosion. Several important attributes of soil condition must be evaluated. These include classifying the soil, soil texture, soil structure, rooting depth zones, organic matter accumulation, soil $\mathrm{pH}$, and salts.

Altered soil structure and soil surface stability or potential for erosion must also be assessed throughout the site to identify problem areas or barriers to vegetation recovery. Mapping the different soil types and assessing their alkalinity and salinity levels within the restoration site will help define which plant communities and species will recover or recruit within these areas. An overview of the attributes of hydric soils, and measures to mitigate hydric soil damage, are covered in Chapter 6, Hydric Soils.

The lack of a viable native seed bank or the presence of a non-native seed bank can be significant limiting factors. A seed bank is an important component of the vegetation community, but is seldom addressed in restoration project planning. Seed banks may differ considerably from the existing vegetation but indicate potential vegetation recovery following restoration. For example, if a wetland has been drained or has remained dry for many years, a component of the seed bank flora may have been lost due to seed death under drought conditions (Budelsky and Galatowitsch 1999). The remaining seed bank may be composed of only a few species with seeds adapted to prolonged dry conditions (Weinhold and van der Valk 1989). Annual species and perennial species that exhibit some mechanism of seed dormancy and physiological longevity are typically represented in the seed bank.

Assessing the potential for natural vegetation recovery is a crucial step in the planning process, because it will determine the level of need for other vegetation management actions, such as active revegetation and weed treatment. Because revegetation is so expensive and labor intensive, identifying wetlands that exhibit potential for natural recovery is the most practical and costefficient method of restoring native wetland plant communities. Wetland vegetation site assessments can be used to project community recovery of wetland vegetation (Figure 4.2).

Another useful planning tool in assessing and predicting natural vegetation recovery is conducting a seed bank test (Figure 4.3). Seed bank tests can help determine species composition and predict the potential recovery of the plant community. For depressional wetlands that have been subjected to long periods of drought, the test can indicate if the seed bank is still viable, or if it will be necessary to reseed a restoration site because of seed viability characteristics and dispersal limitations (Mulhouse and Galatowitsch 2003; Galatowitsch and van der Valk 1996 a, b; Kettenring 2006; Kettenring and Galatowitsch 2011).It can also provide an indication of the presence of weed species in the seed bank and their potential impact on the restored plant community. Further, it can indicate a component of the wetland flora that is not currently evident on the restoration site. Seed dormancy mechanisms and longevity vary widely among species, so seed bank tests seldom capture the full range of potential vegetation. While the test is not 100 percent reliable, it does provide the planner with a rough estimate of the species composition of the seed bank and the potential for germination and 


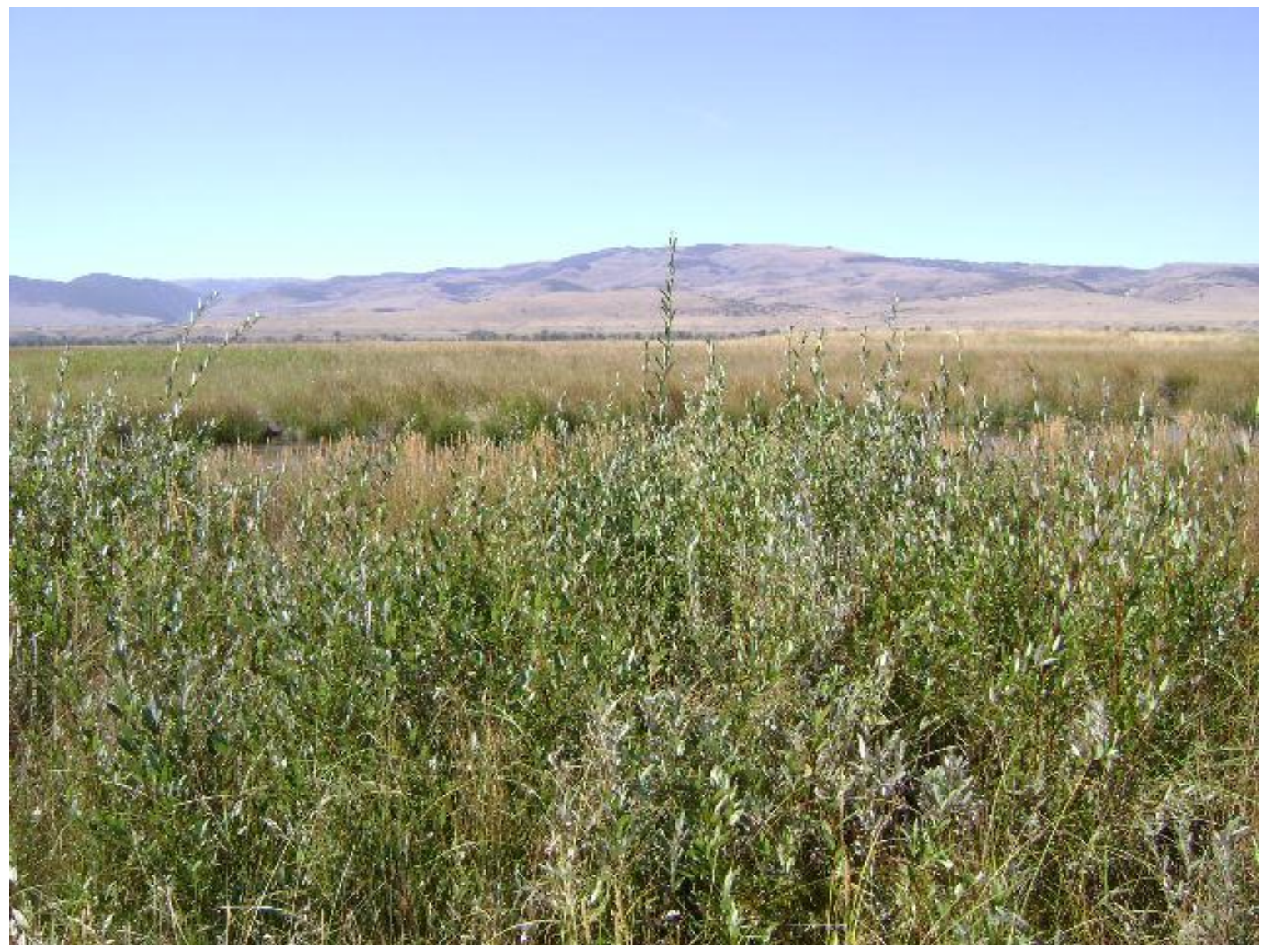

Figure 4.2. Natural regeneration of willows (Photo T. Luna)



Figure 4.2 Seed bank test (Photo T. Luna) 
storage to prevent germination until the test is set

\section{ASSESSING THE SEED BANK}

Temperature and photoperiod are two of the most

important environmental variables in seed

germination testing (Baskin and Baskin 1998).

The laboratory or greenhouse environment in

which the seed bank test is being conducted must

have equipment that provides temperature and

photoperiod control. The goal is to recreate

environmental conditions as similar to the wetland

restoration site as possible. The vast majority of

wetland seeds in northern temperate regions germinate under the long days of summer, with warm days and cool nights which create diurnal air, water, and soil surface temperature

fluctuations. Therefore, seed bank samples should be collected after the soils thaw in spring. During testing, seed bank assays are exposed to 16 hours of light per day and are subjected to alternating temperatures. A general guideline for simulated air temperatures and photoperiod in the western prairie pothole region is $86 / 59^{\circ} \mathrm{F}$ (day $16 \mathrm{hr} / \mathrm{night}$ $8 \mathrm{hr})$.

Seed bank samples must represent the range of variation at the restoration site. Samples must be collected from areas that differ based on hydrology, soils, standing vegetation, and land use (van der Valk 1978, Poiani and Johnson 1988). Samples are collected randomly from each of these areas, using a soil core borer or a hand-held tulip bulb planter. Samples are typically collected to a depth of $5 \mathrm{~cm}$ (Galatowitsch and van der Valk 1996, Poiani and Johnson 1988). This layer contains the majority of viable seeds. Collecting several small samples instead of a few large samples will yield better quality data (van der Valk et al. 1992). Samples are labeled and kept separate in ziplock bags. Samples must be kept cool and moist during transport and temporary up in the lab or greenhouse. Soil samples must be prepared for testing, segregating seeds from roots or rhizomes and other debris by screening the soil through a small mesh sieve or screen. Removed rhizomes and root fragments can be used for running a separate test, if desired.

It is important to use shallow, sturdy trays with drainage holes for running the test. Trays must be a minimum of 6-7 $\mathrm{cm}$ deep. The bottoms of the trays are filled with $2 \mathrm{~cm}$ of sterile large grade horticultural perlite or pumice. This porous material will prevent algal blooms during testing. Another $2 \mathrm{~cm}$ of sterile all-purpose growing media is added on top of the porous media layer, and the potting medium is watered until it is saturated. Finally, 1-2 cm of the moist, sieved wetland soil sample should be spread on top of the moistened potting medium. After trays are placed into a sturdy sub-irrigation tray or trough, the subirrigation tray is filled with water to a depth within $0-1 \mathrm{~cm}$ of the seed trays' soil surface. The water level should be maintained at this level at all times during testing. Maintaining this water level creates conditions that foster seed germination and emergence for both emergent and submergent species (Boedeltje et al. 2002). Trays should be placed randomly in the subirrigation tray or bench.

Trays must be checked for germination and emerging seedlings at least twice per week. Seedlings that can be identified at this stage of growth are counted and removed. Generally, many of the viable seeds will germinate within a 4-6 month period. Seedlings that are not easily identifiable will need to be transplanted to individual containers until they reach a stage of growth that allows identification. Some unidentified seedlings may not produce flowers for several months. 
recovery. However, use of a seed bank test will be limited to instances where there is at least several months' lead time. A general protocol for conducting a seed bank test is described below.

Soils present on the restoration site may contain not only a potential seed bank, but also dormant rhizomes or root fragments of perennial vegetation that have been suppressed due to drought, altered water tables, or other disturbances.. Although it is difficult to predict the full range of species recovery via dormant roots and rhizomes, their presence can help the planner assess potential recovery. Soil samples containing rhizomes and root fragments can be collected and tested in a manner similar to assessing the seed bank. Existing native vegetation composition and cover can indicate recovery and recruitment; however, additional species may re-sprout and appear once the original hydrology of the site has been restored.

Soil samples can also indicate the presence or extent of invertebrate egg banks, which can be used as a baseline to monitor invertebrate recovery and species richness over time (Gleason et al 2004). This, is an especially important factor in encouraging waterfowl use and nesting. Like seed banks, sites that have remained dry for many years or occur within intensively used agricultural landscapes may require inoculation to facilitate invertebrate re-establishment.

Non-native species are the most common limiting biological factors on a restoration site. Populations of non-native species or weeds should be mapped as existing vegetation and noted as occurring within the seed bank. Site conditions should also be assessed to determine if they will favor weed invasion following other restoration activities. Site land use history and proximity to other known weed populations are also important considerations. Adjacent upland and transitional plant communities, and the weed species they support, should also be evaluated for invasion potential. Generally, the best prevention for weed invasion is supporting conditions that favor native plant communities to the greatest extent possible. Eliminating unwanted nitrogen inputs (such as fertilizer runoff or excessive cattle use) which can give weeds a competitive advantage may promote native species recovery. New weed sources can be prevented or limited by requiring weed-free, clean equipment during restoration work and by using weed-free seeds and mulches if revegetation efforts are required.

To effectively manage weeds, the restoration planner must become knowledgeable about the project site. The range of weed species that can invade and persist on a site depends on the species and the site conditions. For example, extremely saline wetland sites will have a limited range of weed species that can colonize and persist, whereas a riparian woodland understory could be potentially invaded by a much wider range of species. The planner will need to research in detail several important life history characteristics such as the weed species' life cycle and longevity, methods of reproduction (seeds, rhizomes, or both), flowering phenology and seed maturation, seed longevity, dispersal agents, and potential rates of spread.

The tolerance of a given weed species to differing environmental conditions such as hydrology, local climate, soil types, available nutrients and salinity needs to be determined to the greatest extent possible. With this information, the planner can pinpoint certain areas within the restoration site that are most vulnerable to weed invasion. The planner may then choose a variety of methods to suppress invasion, targeted at particular areas and specific weed species. S/he can also determine which species will be tolerated, eliminated, or contained over the course of site revovery. These efforts will also inform post-restoration weed monitoring and management.

First, it is important to consider whether intensive and extensive weed management practices are 
needed. In some cases, restoring hydrology can eliminate many weed species that cannot tolerate the post-restoration hydroperiod or water depth. Presence of some annual or biennial agricultural weeds that are able to grow under some periods of inundation may be tolerable during the first couple of years following restoration, as native wetland perennials recover and establish over time. Perennial species, on the other hand, can significantly limit native species recovery. Introduced, perennial hay species such as smooth brome (Bromus inermis), meadow foxtail (Alopecurus pratense), Garrison's creeping foxtail (Alopecurus arundinaceus), Kentucky bluegrass (Poa pratensis), and common timothy (Phleum pratense) can significantly limit reestablishment of native plant communities in some wetland systems, or within certain hydrological zones of the community. Well established communities of highly aggressive species such as common reed (Phragmites australis), reed canarygrass (Phalaris arundinacea), and Canadian thistle (Cirsium arvensis) will require containment by ecologically appropriate means. In some cases, modifying available nitrogen can reduce the competitive advantage of invasive species such as reed canarygrass (Perry et al 2004).

Finally, land use adjacent to and within a wetland can have a significant influence on its ecological processes. These disturbances can usually be traced as causes for other limiting factors on the site. Depending on the degree of disturbance and damage, land use practices such as intensive agriculture or heavy equipment use may need to be eliminated, highly restricted, or controlled to allow for recovery of water quality, soils, invertebrate populations, and vegetation, and to encourage wildlife use, especially during the first few years following restoration. In many cases, the inability to control these limiting factors will make a site less suitable for restoration.

\section{Summary}

Restoration planning requires intensive evaluation of the wetland site and a range of similar reference sites to develop clearly defined restoration objectives. All attributes that contribute to ecological integrity and function must be carefully evaluated and mapped. Current and historical maps and data layers are useful for delineating abiotic influences on site recovery such as hydrology, groundwater tables, topography, soils, and adjacent land use influences All of this information can be used to assemble a comprehensive restoration plan and map. Identifying and integrating all the potential limiting factors into the restoration plan will ensure that all necessary steps have been taken to maximize recovery potential. These tools can also indicate potential for exotic invasion, limitations to native seed and invertebrate recruitment and, and other efforts needed to restore any component of the ecological community. Most importantly, timing of the restoration project is critically important. Every restoration plan will be unique. Each should provide a coordinated timeline for necessary restoration management actions, which ultimately can reduce costs and setbacks to site recovery. 


\section{Chapter 5: Restoring Hydrology}

Wetland hydrology in the Prairie Pothole Region is complex and variable, influenced by geology, geomorphology, surface water/ground water interactions, evapotranspiration, recharge, and climate. These drivers can vary considerably depending on topography and watershed position (Cohen et al. 2006). However, the success of wetland restoration depends on a functioning hydrologic regime appropriate for the wetland type.

\section{Hydrology of Depressional Wetlands}

Depressional wetlands receive their primary input of water from snowmelt and significant rainfall events occurring spring and summer. Annual precipitation ranges from over $387 \mathrm{~cm}$ (60 in) in the western portion of the region to $90 \mathrm{~cm}$ (14 in) in the northeastern portion (McIntyre et al. 2011). Water is lost from depressional wetlands primarily through evapotranspiration, which usually greatly exceeds precipitation during summer months. In southwestern Saskatchewan and eastern Montana, evaporation exceeds precipitation by $60 \mathrm{~cm}$ (27 in) (Winter 1989, Euliss et al. 1999).

Depressional wetlands exhibit variable flooding regimes and can be classified as temporarily, seasonally, semipermanently, intermittently, or permanently flooded (Cowardin et al. 1979). Temporary wetlands typically are small, shallow basins that only hold water for 1-2 months (Johnson et al. 2010). Consequently, many of the temporary depressional wetlands in the northcentral and northeastern portion of the region may be dry during most years, having surface water only during years of high precipitation. Seasonal wetlands are usually larger basins that will hold water for up to 2-3 months (Stewart and Kantrud
1978, Johnson et al. 2010). Depressional wetlands can be connected to one another as complexes, with connectivity occurring both through surface water and groundwater (Winter and Rosenberry 1998, van der Valk 2005, Johnson et al. 2010). In these cases, water retention within shallow wetlands may be greater than in hydrologically isolated wetlands driven only by surface inputs and evaporation (Winter and Rosenberry 1995).

Depending on their influencing geology and hydrology, wetlands can be recharge sites, discharge sites, or flow-through sites; topographic position alone does not fully reflect prairie pothole hydrology (Leibowitz and Vining 2003). Flows can also reverse on a seasonal basis: an individual pothole can be a discharge wetland in the spring, receiving ground water from uplands, and later in summer become a recharge wetland in summer as evapotranspiration creates a groundwater sink (Winter 1989, McIntyre et al. 2011).

Surface connectivity occurs among some prairie potholes and open depressional systems and some marshes, with topographically lower wetlands receiving inputs from upslope wetlands (Winter 1989, Winter and Rosenberry 1998). In some areas, surface water connections may be sporadic, appearing when periods of intense rain result in overflow, forming temporary connections to adjacent wetlands. This "temporal connectivity" likely occurs in fewer cases and over a longer time intervals in the western Prairie Pothole Region. When surface water connectivity links larger upslope wetlands to smaller downslope wetlands, it can increase electrical conductivity and salinity (Leibowitz and Vining 2003), both of which contribute to the dynamic expression of dominant plant and invertebrate communities from year to year (Stewart and Kantrud 1972, Euliss et al. 1999). 
The hydrology of depressional wetlands in the Great Plains region can sometimes be identified by assessing plant community types and the effects of salinity, although these relationships can change over time. Saline depressions and potholes with high levels of salinity are usually $g$ roundwater discharge wetlands. Depressional wetlands classified as temporarily flooded usually recharge groundwater (van der Kamp and Hayashi 1998), whereas those classified as seasonally flooded are generally either flow-through or groundwater recharge systems (van der Kamp and Hayashi 2009). Semi-permanently flooded depressions and potholes can have either groundwater discharge or flow-through functions (van der Kamp and Hayashi 1998, 2009; Euliss et al. 1999). A thorough analysis and $u$ nderstanding of the hydrology of the wetland and its relationships to water inputs and groundwater connectivity is needed to fully achieve restoration goals.

\section{Restoring Hydrology}

Restoring hydrology, hydroperiod and water volume to the greatest extent possible is the first priority in bringing back wetland ecosystem integrity and function. Many wetlands embedded in native grassland landscapes may require only a few measures to maintain or restore their natural hydrology: altered grazing practices, proper culvert placement and maintenance where roads are involved, and an adequate native upland buffer to prevent excessive sediment transport into wetlands. However, many isolated wetlands occur within or adjacent to agricultural cropland with little or no upland buffer around them. These sites will require more intensive evaluation, planning, and active management to restore and maintain hydrologic integrity.

Careful planning is critical in restoring hydrology to a wetland. All other factors associated with restored wetland function and ecological recovery depend on the success of restoring hydrologic connectivity (if present) or modifying all controllable factors that affect potential groundwater input or surface flow. In the planning process, groundwater table maps, if available, can be used to understand and predict hydrologic dynamics, influences on the wetland restoration site, and the relationship to any interconnecting or associated wetlands. When groundwater table maps are not available, groundwater models can sometimes be constructed from well data and geologic maps. Although time-consuming to build and less accurate than maps based on physical surveys, these models can be used as rough guidelines. Topographic quad maps and digital elevation models also can be used to predict possible groundwater connectivity, location, extent, and original topography of the area. Maps of land ownership, ground cover, and other resources are also useful in determining the restoration approach. In many cases, the original extent of wetland area may not be fully evident due to existing roads, water diversions, and current adjacent land uses.

Soil maps may be helpful in identifying the historical extent of hydric soils and current and historical water regimes. This is especially true in agricultural settings where sedimentation has occurred and where national hydric soil maps are being revised. In any case, careful onsite inspection for the extent of hydric soils and presence of relict hydric soils can indicate the potential recovery of hydrology, water volume or changes in hydroperiod.

Many large depressional wetlands in the prairie pothole region seldom reach bankfull condition now due to changes in water infiltration upgradient from these wetlands. These changes have largely been caused by cropping patterns, drainage and diversion of surface water, groundwater depletion, and development of roads and other infrastructure within the watersheds that supply these wetlands. 
In any case, with the possibility of significant climatic effects on future runoff patterns, restoration goals for natural depressional wetlands are best based on a conservative picture of anticipated flow rather than what is generally known from area residents about wetlands past.

Commonly used techniques for restoring hydrology in depressional wetlands include removal of or compensation for sedimentation and other effects to hydrologic input or surface flow (Galatowitsch and Van der Valk 1998). The original topography of the site must be restored to fully capture the hydrologic potential of the wetland. Restoring the original topographic relief of the wetland must occur on sites affected by high levels of sedimentation and erosion, inadequate existing buffer zones or other impacts. However, the cost of removing sediment from a wetland impacted by large-scale sediment transport nearly always precludes restoration of significant wetland acreage. More typically, wetland restoration involves plugging or filling drainage ditches, cutting or removing drainage tile lines, or creating an embankment or levee to capture surface flow rather than investing in large-scale excavation, which is cost prohibitive.

To the greatest degree possible, the adjacent buffers around restored wetlands must be concurrently restored and protected from cultivation, heavy livestock use, and other longterm impacts. Adjacent slope and soil texture must be considered as factors influencing appropriate buffer width. Steeper slopes and coarser soils can increase the likelihood of sedimentation by erosion; these areas typically require greater buffer widths than areas with gentler slopes and finer textured soils. The restoration planner must consider influencing effects of soils as well as original composition of the prairie when restoring watershed and wetland potential. The practice of using non-native grasses such as smooth brome (Bromus inermis) to provide nesting cover for waterfowl and other birds has been shown to have deleterious effects on wetland hydrology in cropland conservation plantings (van der Kamp et al. 1999; 2003; Gleason et al. 2011). In the prairie pothole region of Montana, large numbers of wetlands are surrounded or adjacent to large tracts of crested wheatgrass (Agropyron cristatum), which typically forms a monoculture, and likely has the same negative effects on wetland hydrology as other introduced species.

Native grassland community composition varies from the Rocky Mountain Front to the NorthCentral region, following the precipitation gradient. Rough fescue (Festuca campestris) and Idaho fescue (Festuca idahoensis) dominated prairie occur extensively on the Blackfeet Reservation. Communities dominated by a mixture of short grasses characterize the north-central and northeastern region, depending on soil types, topography, precipitation patterns and past disturbances. Grasses such as western wheatgrass (Pascopyrum smithii), green needlegrass (Nassella viridula), blue grama (Bouteloua gracilis) and needle and thread (Hesperostipa comata) are frequently dominant components, as well as a mixture and diversity of forbs. Remnant prairie of shortbristle needle and thread (Hesperostipa curtiseta) dominated grasslands can be found in northernmost Montana, North Dakota, and adjacent Saskatchewan. Mindful of this natural variation, buffer zone conservation plantings should only use the appropriate mixtures of native grasses and forbs that would naturally occur on upland soils adjacent to the wetland restoration site. These mixtures should be carefully formulated based on reference sites. For information on reseeding native grassland buffers, see Chapter 8: Stock Selection and Site Planting. 
Restoring or maintaining adjacent buffer zones of native vegetation can reduce additional or continued sedimentation (Skagen et al. 2008). Sediment loads have deleterious effects on the wetland seed and invertebrate egg bank (Gleason et al. 2003), as well as causing wetland volume loss. The required minimum native plant community buffer width may vary depending on upland soil type and texture, potential for erosion and adjacent land use (Hong-Ren et al. 1997; 1999). Buffer effect will depend on vegetation structure, width, and other attributes of the surrounding watershed, including area, vegetation cover, slope, topography, soil type and structure, soil moisture, adjacent land use, and intensity and duration of runoff events. Further research is needed to establish guidelines for appropriate buffer width, which may vary depending on wetland type, hydroperiod, landscape setting, adjacent soils and other factors.

Wind and water erosion are the primary drivers of sedimentation in depressional wetlands within agricultural landscapes (Gleason and Euliss 1998). Soil samples should be taken from around the wetland basin to assess the extent of sedimentation extent and its influence on site hydrology. Five to ten soil core samples can be taken at equidistant intervals around the wetland basin. The decision to remove sediments should be based on estimates of reduction in hydroperiod and the cost-benefit ratio. Shallower wetlands occurring on gentler slopes can be negatively affected by even moderate amounts of sedimentation. On sites exhibiting sediment loading, sediment removal should approximate original topography or microtopographic relief to restore hydric soil and water levels, or to compensate for sediment levels that cannot be feasibly removed without damaging the wetland.

If sediment removal is part of the restoration plan, great care should be taken to prevent damage to hydric soils and the existing seed bank.
Interception of porous sand and gravel layers under such wetlands will limit or preclude the maintenance of their water-holding capacity. Equipment is used to remove sediments, and even slight errors can remove the upper hydric soil layer containing the seed bank. Experienced contractors use low ground pressure equipment to remove sediment layers; when timed correctly, soil damage is minimal.

Water diversions that can modify hydrology and increase sedimentation include roads and other transportation infrastructure; energy development, exploration, and production sites; and culverts, ditches, pumps, and drains. Much of the western PPR contains numerous roads, many of which are elevated and lack adequate culvert systems. These can affect surface water flow and increase sedimentation (Gleason and Euliss 1998). Modification of existing water diversions and obstructions to surface water flow is needed to achieve original water depths and hydroperiods.

Many wetlands were drained during the 1900 s by the construction of surface ditches. Restoring hydrology to these wetlands involves filling part or all of the drainage ditch. It may be impractical to completely fill ditches if the original borrow material was removed or has eroded away over time. However, when the spoil material is still adjacent to the ditch, this material should be used to create the necessary ditch plugs and fill as much as possible.

Filling drainage ditches involves pushing spoil banks or soil plugs into the ditches with heavy equipment to stop drainage and retain water in the wetland. Compaction of ditch plugs and fills is important to prevent erosion of these fills if surface water continues to follow the ditch after restoration. To restore hydrology to the greatest extent possible, the site location for a ditch plug needs to be chosen carefully following completion of an elevational survey. Where wetlands occur 
along the margin of these ditches, regulatory requirements may dictate avoiding, minimizing, or offsetting impacts to these fringe wetland areas. General recommendations are to plug at least $46 \mathrm{~m}(150 \mathrm{ft})$ of ditch if the soils are organic and $30 \mathrm{~m}(100 \mathrm{ft})$ if soils are mineral. The plug should rise 33 percent above grade for organic soils and 20 percent above grade for mineral soils to allow settling of soil over time (Galatowitsch and Van der Valk 1998). However, with good compaction, 10 percent overfill will be adequate with mineral soils (Connelly 2010). Topsoil and native vegetation should be stripped from ditch bottom and banks at the plug site and carefully stockpiled. However, vegetation should be carefully evaluated for species composition to prevent establishment of weeds and invasive native species.

Because of erosion and settling, spoil piles often will not provide enough material for plug material and fill, so alternative borrow sites will need to be carefully selected. The cost associated with hauling, placing, and compacting fill material from off-site must be considered when deciding how much of the ditch's length will be filled. Clean, weed-free fill material should be used to construct ditch plugs with material placed in 6-8 inch lifts and compacted before the next lift is placed. Gentle slopes should be created that include at least a 5:1 ratio, where for every $1.5 \mathrm{~m}$ $(5 \mathrm{ft})$ of length the level goes up $0.3 \mathrm{~m}(1 \mathrm{ft})$ for front and backslopes of the plug. When the plug is completed, stockpiled topsoil should be spread over the plug and borrow sites. In some cases, the plug and borrow sites may need to be reseeded with appropriate native species. If properly constructed, ditch plugs are usually maintenance free once vegetation is established.

Filling and re-contouring the entire length of the ditch is the preferred method if funding is adequate. Complete filling will result in a more effective and permanent restoration of site topography and hydrology than a simple plug. Typically, ditches are rimmed by spoil banks that consist of soil that was excavated when the ditch was created. Spoils placed along ditch banks create unnatural topographic relief and can inhibit water flow across the site. Spoils also have other negative effects; frequently, they have been colonized by invasive weeds and provide stalking cover and travel routes for waterfowl predators. Ditches should be filled with spoil soils from the embankments. Filling an entire ditch may be 3-10 times as expensive as a simple ditch plug. However, ditch filling may be more cost effective than using plugs on some sites, because more wetland can be restored using a ditch fill than with a ditch plug alone. Furthermore, a c ompletely filled ditch is even less likely to require maintenance than a simple ditch plug.

In many cases, even when the ditch is completely filled, plugs are constructed at the highest elevation along the former ditch. Spoil is filled in the remainder of the ditch upstream and downstream of the plug. Adequate compaction is key when plugging and filling ditches. Correct placement of the ditch plug will ensure hydrologic restoration to the greatest extent that is possible.

Filled ditches and tops of ditch plugs can be highly vulnerable to weed and invasive native species. Cattails, Canada thistle, reed canarygrass and common reed can colonize these areas easily. This is especially true if the fill material remains moist for most of the growing season; when native sod has not been properly stored or replaced; or when native species are absent from the spoil material. Cattail produces a huge amount of seeds, which exhibit no seed dormancy. Seeds can germinate and establish at any time of year (spring, summer, and fall months) and under a range of cold to warm soil temperatures. Furthermore, cattail has a highly competitive root system, which can activate growth under colder soil temperatures. Cattail, reed canarygrass and common reed can occupy a range 
of wet to dry conditions. If the root systems or root fragments are present within spoil material, these species can spread rapidly, cover more area in a single growing season, and take up more available nutrients and space in a shorter period of time. In these cases, additional revegetation efforts with filled drainage ditches may be required. Methods include using salvaged native graminoid sod mats, planting native rhizomatous springs or seedlings, appropriately timed reseeding, and pretreating native seed to maximize germination potential.

Modifications to wetland topography and hydrology are common in this region. Many depressional wetlands have been modified by berms or other impoundments to create livestock ponds and to provide more open water habitat for migratory waterfowl. Many of these wetland improvements occurred on federal land in this region during the 1960s and 1970s. Today, these modifications are incorporated in long-term wildlife conservation planning, especially in this drought-prone region.

Restoration sites that feature stream channelization and realignments can occur in wet meadows adjoining river floodplains and may include other drainage alterations. Meandering streams may have been realigned and their channels straightened, widened and deepened, or ditched. In these cases, the restoration planner can restructure and restore the original watercourse using old aerial photos, topographic maps, and the topography of the site as guides. Reconfiguring a stream requires specialized knowledge and experience.

Generally, goals for stream restoration are to improve sediment transport and flow conveyance, and to improve aquatic habitat. Restoration actions usually involve excavating a new channel that exhibits cross-sectional dimensions characteristic of natural spring creeks. Spoil material from the new meandering channel is used to fill the straightened channel or ditch. Material is added to a depth that allows the former channel to function as an emergent wetland. Banks along the constructed meandering channel are constructed of native sod mats salvaged during channel excavation. Some common native river floodplain graminoid communities are composed of species with vigorous rhizomatous root systems. With proper temporary storage and replacement of these sod mats, the area will fill in the former channel in a relatively short time. Construction of a new, meandering stream channel within a river floodplain wet meadow requires considerable knowledge and planning. However, the benefits to restoring flow to the wetland complex and providing wildlife and fish habitat often justify the costs of construction.

\section{Summary}

The success of any wetland restoration project will depend on a functioning and sustainable hydrologic regime appropriate to the wetland type. Because there is so much spatial and temporal variability in the hydrology of PPR wetlands, a thorough analysis and understanding of the hydrology of the restoration target is necessary in every case. Maps, models, surveys and thorough field investigations should all be used in this effort, as well as local knowledge about high water frequency and duration. Much of the western PPR is criss-crossed by elevated lacking adequate culvert systems. In some cases, modification of water diversions and obstructions to surface water flow will be necessary to achieve original water depths and hydroperiods. Similarly, wetland drained by the construction of surface ditches will require ditch plugging, and in situations where sedimentation and erosion have been caused by upland land use, restoration of topographic relief may be necessary. 


\section{Chapter 6: Hydric Soils}

Wetland and riparian areas exhibit a range of hydrological conditions, from permanent saturation to periodic inundation or flooding, which result in the formation of hydric soils. Hydric soils are formed under a reducing environment that is characterized by limited free oxygen in the soil profile. Under these anaerobic conditions, specific biological and chemical reactions begin to predominate that do not occur under the aerobic conditions of upland soils. Over the course of many years, hydric soils develop unique properties that are easily identified from soil samples.

Wetland and riparian species are adapted to hydric soils and can thrive in low oxygen soil environments, either for brief or extended periods of time. In this chapter, we provide an overview of the general characteristics and indicators of hydric soils and methods to mitigate for hydric soil damage and erosion.

\section{General Characteristics of Hydric Soils}

Hydric soils develop under conditions of prolonged inundation, flooding, or ponding sufficient to form anaerobic conditions in the upper layers of the soil profile (Richardson et al. 2001). Typically, soils must be saturated near the soil surface (usually within $1 \mathrm{ft}$ ). Hydric soils can develop under a range of hydrological regimes ranging from permanent saturation, short duration flooding and periodic saturation by groundwater. The presence of excess water isolates the soil from atmospheric oxygen and prevents oxygen from entering the soil profile. Prolonged soil saturation increases the activity of oxygen-consuming microorganisms, creating a low oxygen environment or anaerobic state. Low oxygen content induces biogeochemical processes that lead to elevated concentrations of iron and other elements, organic matter accumulation, grey colored subsurface horizons, and the production of gasses (Arndt and Richardson 1988).

The upper part of the soil profile may be saturated by a high water table, by flooding or ponding, or by the presence of stratified restrictive soil layers that impede water movement. A soil is considered saturated when the soil water pressure is zero or positive. During soil surveys, water will flow from the soil matrix into unlined auger holes. The capillary fringe moves water upward to the soil surface. On some wetland sites, impermeable subsoils form a restrictive layer that will perch water. In these cases, water will perch above the clay-sand boundary.

Oxidation-reduction (redox) reactions occur under anaerobic conditions and contain reduced forms of manganese (Mn), iron (Fe), or sulfur (S). Under saturated conditions, atmospheric oxygen is prevented from entering the soil profile and biological activity produces electrons. The morphological indicators of hydric soils are produced by reactions involving four elements: oxygen (O), Mn, Fe, and S (Vepraskas and Faulkner 2001). Mn and Fe frequently occur together and provide the most visible indicators. Redox reactions produce visible changes that can be seen in soil samples. In subsoil horizons, Fe and Mn oxides give soils a brown, yellow, or red color.

Redox depletions occur when soils are saturated and iron $(\mathrm{Fe})$ and manganese $(\mathrm{Mn})$ are reduced to a soluble form. When reduction occurs, Fe and Mn are mobile and can be stripped from the soil particles, leaving only the characteristic mineral grain color of the soil matrix. Soils are often grayish (gleyed) or black in color. Redox concentrations form when Fe oxidizes under fluctuating groundwater levels of the course of the year. Fe redox concentrations are orange to reddish -brown in color. Mn redox concentrations are dark 
concentrations are dark reddish-brown or reddishblack. Redox concentrations are readily visible from hydric soil samples and can occur as nodules or concretions, mottles, or as pore-linings along root channels (Figure 6.1).

Some general indicators of hydric soils (NRCS 2002) include:

- histosols (an organic layer $>20 \mathrm{~cm}$ deep);

- histic epipedon (organic layer $\geq 20 \mathrm{~cm}$ from surface);

- distinct odor due to anaerobic conditions (sulfuric or rotten egg odor);

- organic streaking in subsurface layers (dark vertical streaks leached into subsoil layers);

- gleyed or low chroma colors;

- redox depletions (areas in soil that have lost iron; gray or reddish-gray in color); and

- redox concentrations (oxidation of iron; nodules or masses that occur in patches, along root channels and in pores).

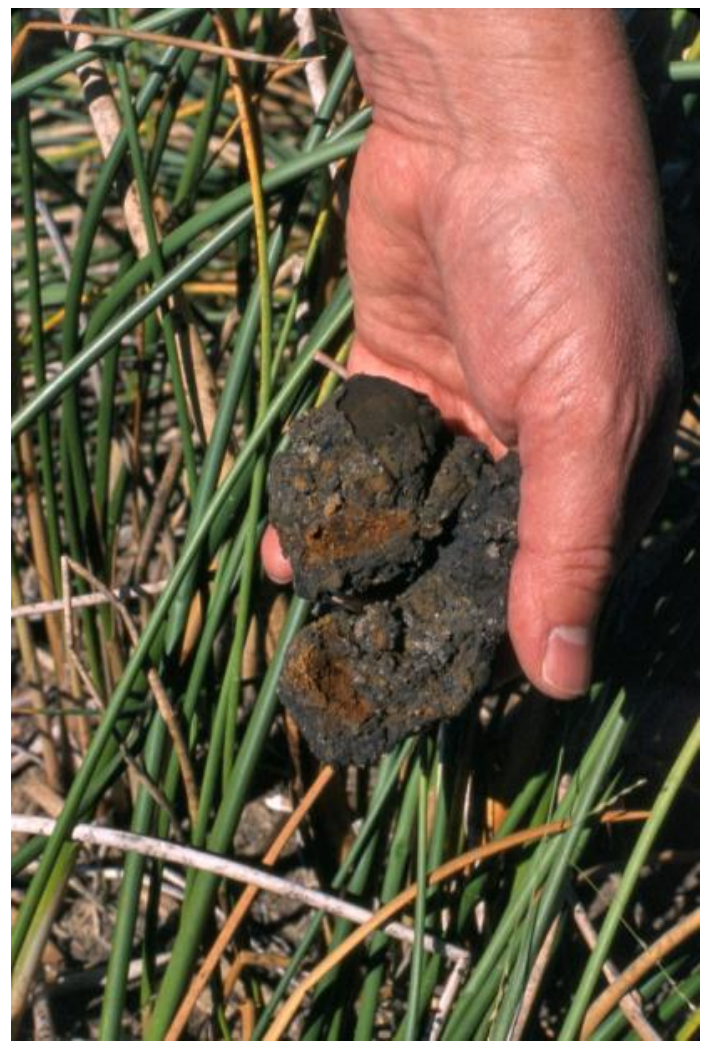

Figure 6.1. Redox features in hydric soil (Photo T. Luna)

\section{Hydric Soil Horizons}

Soil samples are characterized by specific layers with physical characteristics that differ from other layers in the soil profile (Soil Survey Staff 1999). The stratification of soil horizons results from different biological and chemical processes in conjunction with influences from the parent materials. Descriptions of soils horizons define how soils are classified. The main descriptors for soil horizons include soil color and soil texture. Any given soil sample contains at least one horizon.

Soil horizons are described in distinct layers; including $\mathrm{O}, \mathrm{A}, \mathrm{B}$, and $\mathrm{C}$. The $\mathrm{O}$ horizon defines the organic layer. This surface layer contains predominantly organic material, or humus, in varying stages of decomposition. It is distinct from the leaf litter layer, which does not contain any weathered mineral particles. The A Horizon is the top layer of the soil horizons or 'topsoil'. The A horizon is usually darker in color than the B horizon because it contains more organic material than deeper, subsurface layers. The majority of biological activity occurs in the $\mathrm{O}$ and A horizons relative to the $\mathrm{B}$ horizon.

The B Horizon is commonly referred to as 'subsoil', and consists of mineral layers which may contain concentrations of clay or minerals such as iron, or heavily leached organic material. Typically, it will have a textural or color description that is distinct from the A horizon. The $\mathrm{C}$ horizon is usually distinct from the $\mathrm{B}$ horizon in that it lacks any visible signs of weathering and contains large fragments of parent material.

\section{Describing and Evaluating Hydric Soils}

Several important attributes of soil conditions must be evaluated when describing hydric soils (NRCS 2002). These include classifying the soil by color, 
redoximorphic features, texture, and depth of the different horizons. For restoration project planning, other features of the soil must be evaluated, including a thorough assessment of soil texture, soil structure, rooting depth zones, organic matter accumulation, soil $\mathrm{pH}$ and salts, and soil stability.

\section{Soil Color}

The predominant soil color, called the matrix color, occupies more than half of the soil horizon. Soil color is determined by a standardized system of color descriptions using a Munsell Soil Color Chart (Figure 6.2). This system determines three color dimensions: Hue, Value, and Chroma. The Hue of a color indicates its relation to red, yellow, green, blue, and purple. Value can be described as relative lightness or darkness of pigmentation.

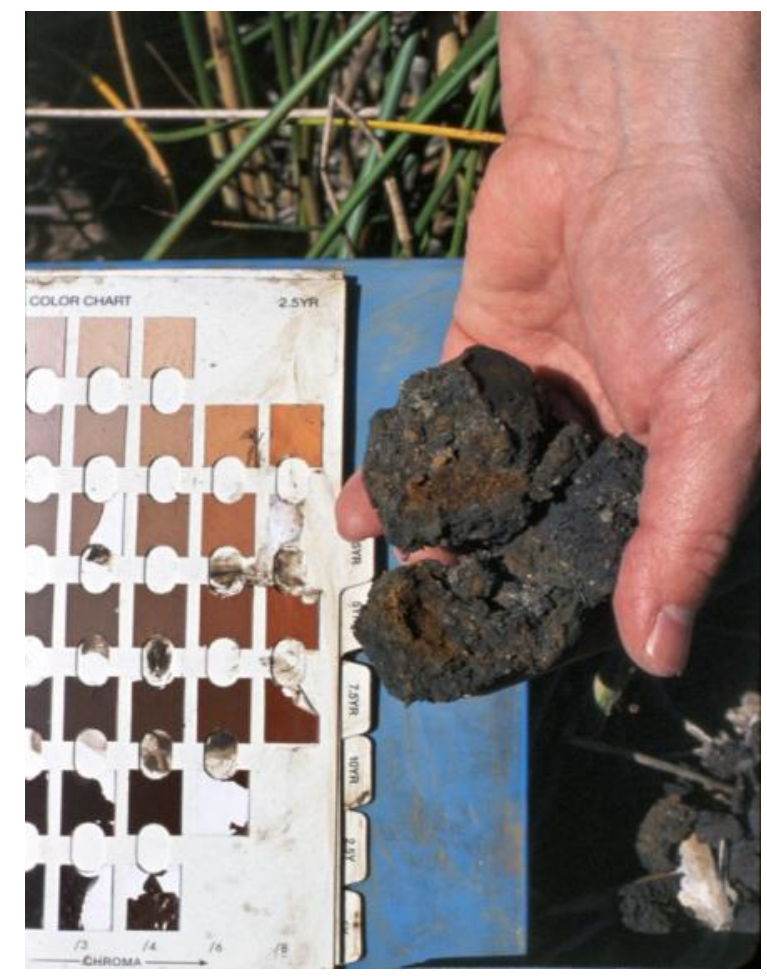

Figure 6.2. Munsell soil chart (Photo T. Luna)
Chroma describes the richness of pigmentation (pale to bright). Mottles are small areas that differ in color from the horizon matrix; these form from saturated conditions and redoximorphic reactions. Colors of redoximorphic features must also be described using the Munsell Color Chart. The relative abundance of redoximorphic features should be included in the horizon description.

\section{Soil Texture}

Soil texture is the relative percentage of sand, silt, or clay in a soil. It determines the crucial function of soil water storage due to the arrangement of pores exhibited by each textural class (Figure 6.3). Soil texture can be determined by using the soil textural pyramid and by the feel of the soil between the fingers. Clays are typically thin with highly charged surface areas that retain large amounts of water. Clays tend to be arranged to hold small micropores. In contrast, sands tend to be large round particles that have low surface areas and therefore do not hold as much water as clays. Sands possess large macropores that are beneficial in providing more air and water flow but are poor in storing water. Soils high in silts hold more water than sands due to a larger number of micropores; however, they are not as charged and therefore hold less water than clays. Soil texture can vary between soil horizons. Each horizon should be evaluated to determine water movement, water holding capacity, rooting depth potential, or barriers to root penetration.

Determination of soil texture is important for understanding the available water holding capacity and water movement through the soil. For example, the thickness of the capillary fringe layer above the water table is directly affected by soil texture. The capillary fringe is the subsurface layer in which groundwater seeps up from a water table by capillary action to fill soil pores. Pores at the base 


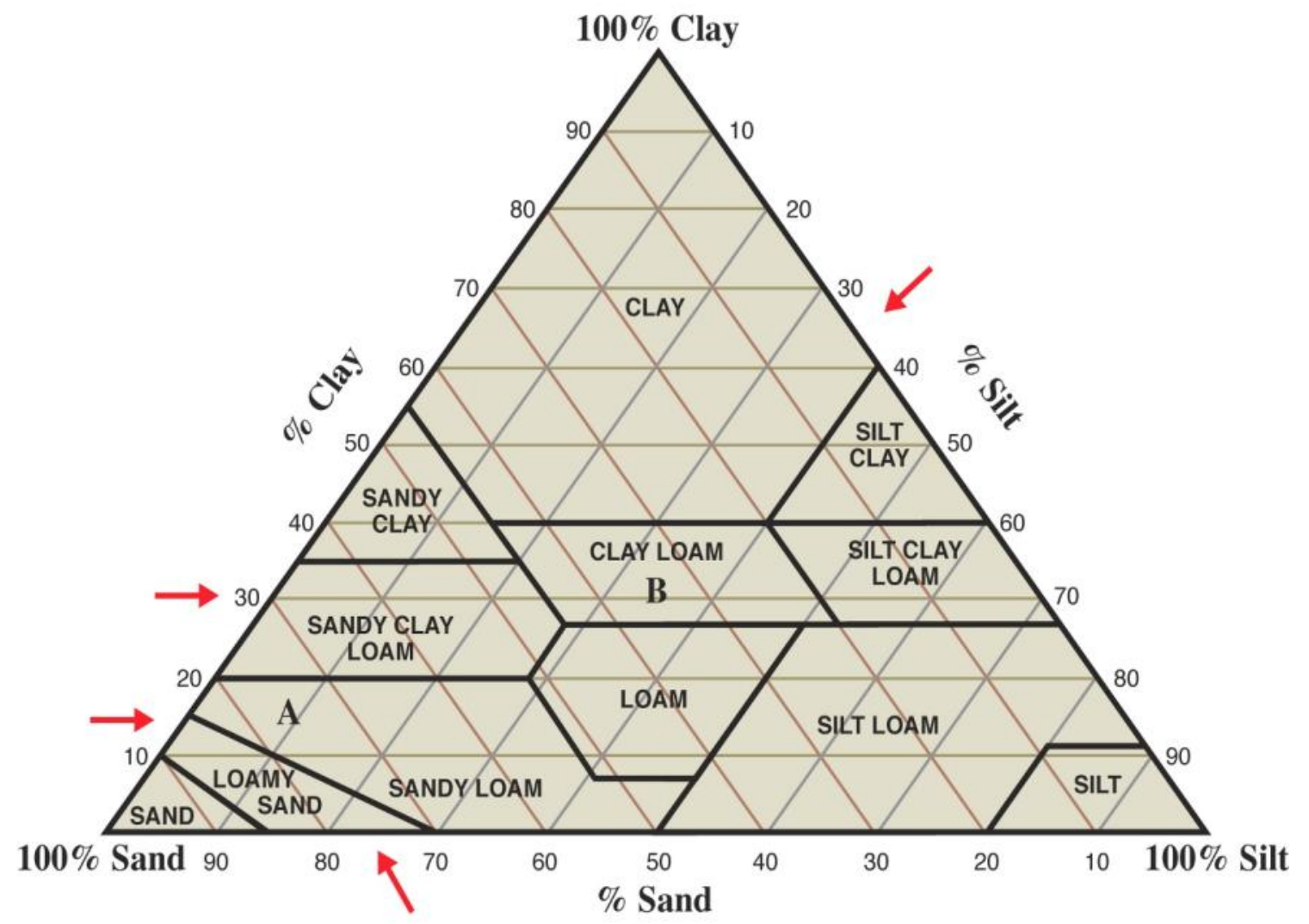

Figure 6.3. Soil texture pyramid (Courtesy T. Landis)

of the capillary fringe are filled with water due to tension saturation. If pore size is small and relatively uniform, it is possible that soils can be completely saturated with water for several feet above the water table. Finer textured soils such as silts and clays possess a thicker capillary fringe due to high soil water holding capacity. Coarser textured soils with larger pores, such as sands, have a thinner capillary fringe during periods of high water. Thus, sandy soils will have lower water content during periods after flooding, but there will be greater air space between the soil pores compared to finer textured soils.

\section{Soil Structure}

Soil structure refers to the arrangement of soil into various aggregates, each differing in the characteristics of its particles. Soils are composed of many-sized mineral or organic particles that make up the texture, but they are also composed of air spaces or "pores", which influence water movement, water storage, available oxygen and root penetration. Small pores (micropores) strongly influence soil moisture holding capacity, while large pores (macropores) influence water movement, air flow, and root penetration. Soil structure is also important for other soil functions such as water infiltration, permeability, drainage, and habitat for microorganisms. Water flow and root penetration depend on good soil structure. Thus, it is important to carefully examine soil structure during soil surveys in order to evaluate its condition.

The rooting depth of the soil must also be evaluated during soil surveys. Barriers to root penetration due to compaction or subsoil 
features can limit vegetation recovery in some cases. Rooting pattern, structure, and morphology varies from species to species but plays a significant role in how a species accesses water. Woody species have the ability to access water at greater depths than herbaceous species. Most emergent herbaceous wetland species have shallow rhizomatous root systems compared to woody riparian species; however, the rooting depth can vary widely among species. Bulrushes, for example, possess root systems that can penetrate soils up to $1 \mathrm{~m}$ to access stored water following draw-down in the wetland, while spikerushes and grasses typically possess much shallower, rhizomatous root systems. Generally, soils must have adequate, unaltered structure throughout the profile to promote root growth and accessibility to water.

Soil structure in hydric mineral or organic soils can be severely compromised in areas of intensive compaction. Soil compaction is greatest when soils are wet and moist, making wetland soils are highly vulnerable to compaction. Heavy equipment use and heavy trampling can greatly alter soil structure. The applied or repeated pressure can reduce or eliminate any macropores, reduce volume, and increase density. Highly compacted soils significantly reduce plant root penetration and growth. This will greatly limit the ability of wetland perennial species to regenerate from within the soil profile and can limit vegetation spread and productivity. Compaction can also compromise or completely eliminate the seed bank by pushing seeds deeper into the soil profile, rendering the seeds incapable of germination. Heavy compaction from cattle trampling or "pugging" significantly impacts the potential for vegetation recovery (Figure 6.4). Pugging also results in micro-topographic changes to the soil surface that alter surface water flow and ultimately shift plant community dynamics (Figure 6.5). Compaction can be evident several inches to several feet below the soil surface, depending on

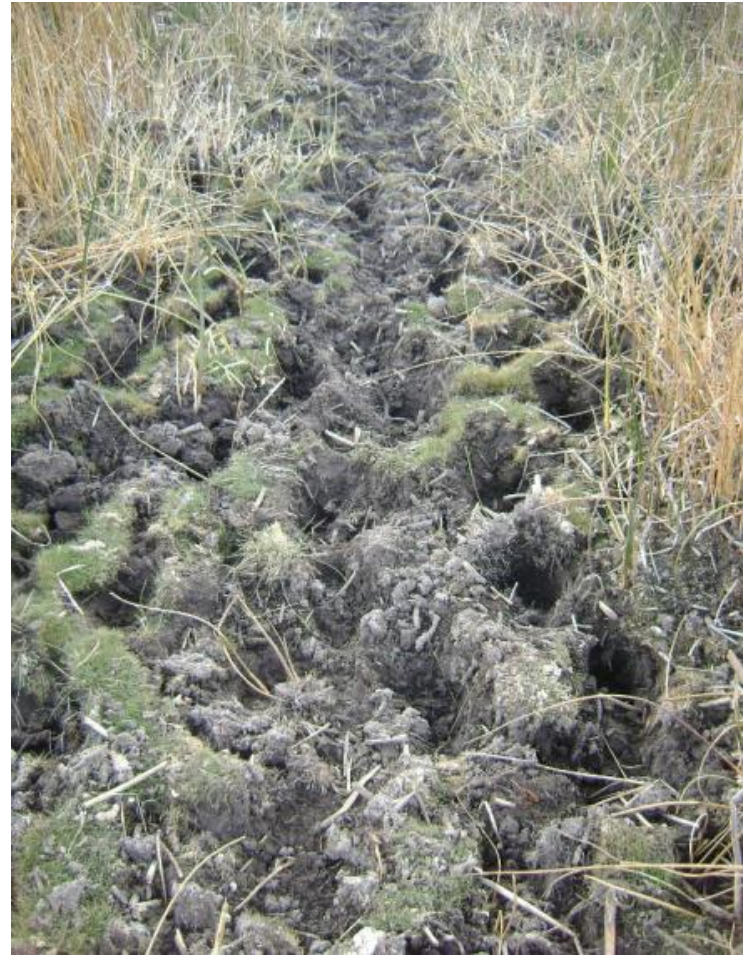

Figure 6.4. Pugging of mineral soil (Photo T. Luna)

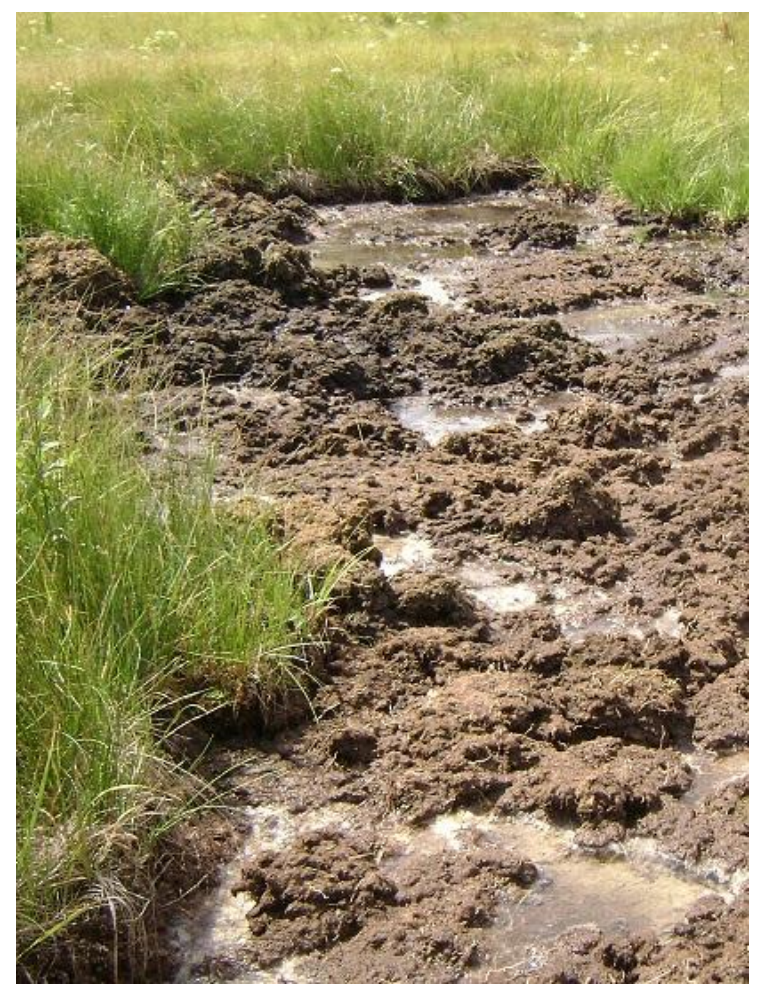

Figure 6.5. Pugging of histic soil (Photo T. Luna) 
depending on the weight of the equipment or intensity of trampling, soil texture, and moisture content. Compaction usually results in a mixing of the A horizon with subsurface horizons.

Compacted layers in forest upland soils can recover to their original porosity through root penetration and freeze-thaw cycles; however, recovery can take up to 70 years (Froehlich et al. 1983). Hydric soil damage due to compaction is very poorly studied and there are no studies indicating time to natural recovery. Some natural recovery does occur due to root penetration, freeze -thaw cycles and wetting and drying cycles, especially for clay and silty-clay soils.

\section{Soil pH and Salt Concentration}

Soil $\mathrm{pH}$ and salt concentrations can be determined using an inexpensive soil $\mathrm{pH}$ and electroconductivity meter. Soil $\mathrm{pH}$ and salt concentration determine which species can colonize, regenerate, recruit, or be revegetated in the restoration site. Higher concentrations of agrichemical salts can occur in wetland soils adjacent to agricultural cropland (Freeland et al. 1999).

\section{Soil Surface Stability}

Surface stability refers to the tendency of soils to remain in place under the erosive forces of water, wind, and gravity. Soil stability is essential for preventing erosion and for the recovery of existing native vegetation or establishing native vegetation; it also contributes to higher water quality. With increasing levels of erosion, plant roots become exposed and soil productivity is reduced or lost. Several factors contribute to soil surface stability, including soil texture, slope length, slope gradient, soil type, flooding events or water input, and existing topsoil cover. Any one or a combination of these factors can limit vegetation recovery. In cases where soil stability or erosion is problematic, additional mitigation measures must be taken to stabilize the soil surface. These methods are discussed later in this chapter.

\section{Organic Matter Accumulation}

Accumulation of organic matter plays a significant role in restoring wetland ecosystem function. Lack of organic matter accumulation can limit reestablishment of the full range of desired plant associations or species. Organic matter accumulation is a function of time, hydrology, and existing vegetation (Kalbitz et al. 2000). Inhibition of organic matter decomposition is favored by long -term anaerobic conditions. Organic matter may accumulate over time after vegetation has recovered, but development occurs very slowly over the course of many decades. Evaluating the range of organic matter accumulation can indicate the potential for vegetation productivity and recruitment as well as recovery of food web structure.

Accumulated litter in varying stages of decomposition supports a diversity of decomposing microorganisms. Recent or intact litter layers support macroinvertebrates, symbiotic mycorrhizal fungi and other soil microorganisms, which in turn support growth and productivity of wetland vascular plants. Recent, intact litter layers can moderate water temperature, thus creating appropriate conditions for a multitude of aquatic organisms. The amount of organic matter accumulation and presence of recent litter significantly influences biological diversity, food web structure, and ultimately, recovery of wetland ecosystem function.

Organic matter is composed of plant biomass in all stages of decomposition and includes wood, roots, leaf and other plant litter, and soil

microorganisms. Decomposing microorganisms are as important as plants in nutrient cycling processes. Decomposers not only release nutrients 
but are essential to the development of soil structure. In relatively undisturbed sites, organic matter is present in all stages of decomposition, from recently dead plant material to humus, which is the end product of many years of decomposition. A site that has a range of organic matter in varying stages of decomposition is indicative of the conservation and release of nutrients over a period of time.

The rate of accumulation depends on plant productivity at the site and the rate of decomposition. Accumulation rates are highest in wetlands with low hydrodynamics and extended hydroperiods that are dominated by herbaceous vegetation. Examples include fens and brackish marshes. Decomposition rates are lowest in these same wetlands. Significant portions of organic matter accumulation come from root production and decomposition. Decomposition rates for roots are slower than above ground shoots and leaves. In contrast, riparian fluvial forests with short hydroperiods and high hydrodynamics exhibit much lower rates of accumulation and much higher rates of decomposition. Shallow, intermittently or temporarily flooded depressional wetlands, such as playas and vernal pools, have short hydroperiods and low water flow. Organic matter accumulation rates are low and decomposition rates are high. Excessive accumulation of organic matter in these wetlands can create conditions for invasion by upland flora and non-native species as well as for detrimental algal blooms.

The rate at which organic matter decomposes and releases nutrients is a function of soil to organic matter contact, organic matter particle size, carbon to nitrogen ratio, moisture, and temperature. Organic matter that is deposited on the surface of the soil will decompose much faster than organic matter that is incorporated into the soil profile. Thus, recent leaf litter on the soil surface will decompose faster than older leaf litter, roots, rhizomes and subterranean shoots. Smaller fragments of organic matter decompose faster than larger fragments. Fine non-woody fragments decompose faster than branches, logs or thick, fleshy roots. Similarly, plant materials with lower carbon to nitrogen ratios, such as grass and sedge leaves, will decompose faster than larger, woody material.

Decomposition rates are lower in northern climates and in wetlands with permanent to semi-permanent saturation. Decomposition and accumulation of organic matter in anaerobic soils differs significantly from aerobic soils. Decomposition is reduced or rendered incomplete and humification of organic materials is decreased under flooded or saturated conditions. Organic soils or Histosols are developed in permanently saturated sites because organic matter decomposes more slowly than it accumulates.

Soil microorganisms are also important for the success of plants and for overall ecosystem function. For example, the hyphae of arbuscular mycorrhizal fungi (AMF) produce glomalin, which creates soil particle aggregates and acts as a glue to bind organic matter to inorganic soil particles (Bothe et al. 2010). Consequently, severely damaged soils may require restoration of the soil microbial community. Certain microorganisms may also facilitate long term restoration of soils with high levels of salts or toxic metals.

\section{Methods for Mitigating Soil Compaction in Wetlands}

In the western PPR, heavy and repeated cattle trampling on saturated or moist soils produces a pugging effect. This results in a remolding and compaction of the surface soils, causing significant loss of soil macropores, mixing of surface horizons with subhorizons, and extensive tearing and burial 
of vegetation and seeds. The depth of compaction can vary from $5-30 \mathrm{~cm}$ below the soil surface, depending on the soil type and the degree of saturation. Water tends to accumulate and remain in the holes, due to compaction and reduced water infiltration into subsurface horizons. This increases the soil's susceptibility to an increasing level of anaerobic conditions, which can restrict plant root growth and change species composition or density over time. Compaction also increases the mechanical resistance to root growth. With repeated trampling, a wetland soil can become severely altered to the point that it can no longer support vegetation or a soil microbial community.

Strategic placement of flavored cattle supplements can facilitate natural recovery and restoration of wetland plant communities and limit repeated damage to wetland soils that have been subjected to intensive grazing (Figure 6.6). Minimizing the time cattle spend near wetland edges can reduce soil pugging and allow vegetation to recover. Vance and Luna (2010) found that, in general, wetlands in pastures where supplements were used did not suffer any degradation, and vegetation cover appeared to increase dramatically over the season, in contrast to the cover decrease seen in wetlands located in pastures where no supplements were used.

When supplements are placed 500 meters or more away from wetland areas, cattle appear to spend more time around supplement barrels. Placing supplement barrels at high points where there is some wind protection and visual advantage keeps cattle near the barrels during resting periods and at night. As an additional benefit, strategic barrel placement located away from wetlands can decrease the amount of fecal material left in or near wetlands, potentially improving water quality. Full recovery of wetland vegetation and soils may require supplement use in pastures for several years coupled with lower stocking rates or deferred grazing. These practices, in combination with annual freeze thaw cycles and wetting and drying, will assist in soil structure recovery.



Figure 6.6. Supplement placed away from wetland (Photo T. Luna)

\section{Methods for Increasing Soil Surface Stability}

Soil surface stability and potential for soil erosion can be an especially important limiting factor on steeper slopes in riparian systems that are characterized as narrow gradients However, as long as there are persistent root systems present on the slopes, they can resprout and re-establish pockets of vegetation cover, thus preventing soil movement on steeper slopes. In some cases, other methods must be used to prevent massive soil erosion. Sites with coarser loam soils, high rock content and low potential for resprouting of woody roots are most vulnerable. In these cases, the most common methods for mitigating soil erosion involve installing barriers with bioengineering materials (cuttings)or downed or partially buried logs, using live sod mats (addressed in Chapter 5), using biodegradable erosion control mats, and application of mulch and seeds. By increasing soil surface stability, these practices can help 
vegetation can reestablish over time. Root systems bind and reinforce the surface horizon a nd anchor the soil to subsurface layers. Stems and woody roots add support to the soil immediately uphill. Soil surface stability should also be evaluated in upland buffer areas, and restored as necessary to minimize for erosion and sedimentation into the wetland.

\section{Bioengineering Materials (Live Cuttings) for Riparian Areas}

Live cuttings are used in streambank restoration to stabilize the soil surface on slopes and thus to prevent soil erosion. Once established, cuttings add surface strength stability to the slope by producing a dense network of interlocking root systems. The most common types of cuttings used for bioengineering purposes are live stakes, live fascines, and live brush layers. Methods for collecting and handling live cuttings are described in Chapter 7, Collecting Seeds and Cuttings.

Live stakes are used to stabilize areas along streambanks that exhibit visible slumping (Figure 6.7). When they are planted in strategic rows down a slope gradient, they serve as live silt fences, catching surface water runoff and sediments. They also can be used to secure biodegradable erosion control mats. During installation, cuttings are either planted by hand or with specialized tools. Most of the cutting length is planted below the soil surface to ensure the cutting produces the maximum amount of rooting area. Usually only one or two leaf buds are visible above the soil surface. It is very important that live stakes are planted in such a way that soil is firmly packed around the cutting so that there are no large air pockets around the cutting.

Live brush layers are cuttings that are planted in excavated benches and covered by soil (Figure 6.8). They are primarily used for slope reinforcement. In some cases, they are installed or are supported on the slope by logs or live fascines. Brush layers are inserted with the end portion of the layer into the slope and with the tips just barely exposed above the soil surface. The layers are firmly covered in soil.

Branchpacking is the layering of live branch cuttings and compacted soil to fill small holes and slumps in a streambank. Branchpacking should be established flush with the existing bank to prevent scouring. Branches need to be long enough to reach from the face of the existing bank to the back of the fill or gully. Dormant cuttings that are 1 to 2 inches in diameter and 5 to 8 feet long are used in combination with lumber stakes. The bottom of the hole is sloped towards the rear of the streambank and rock is used to stabilize the toe of the fill. This technique provides an immediate barrier to reinforce streambanks and prevent bank erosion from overland flow.

Live fascines are bundles of cuttings that are installed in long bundles. Live fascines establish quickly because of the dense number of buds near the soil surface (Figure 6.9). However, they should only be used on moist sites because they are prone to drying out more quickly than live stakes or live brush layers. Fascines are installed in small excavated trenches. The top of the fascine bundle is just flush with the soil surface.

\section{Biodegradable erosion control mats}

Erosion mats are blankets designed to increase soil surface stability and reduce soil erosion. They also serve as a mulch to protect germinating seedlings. They are widely used for streambank stabilization or road slope stabilization adjacent to rivers and streams. Erosion mats made with biodegradable materials are preferred for use because mats with plastic netting fail to break down within a few years. The remaining plastic netting can get into streams, creating hazards for fish and other 

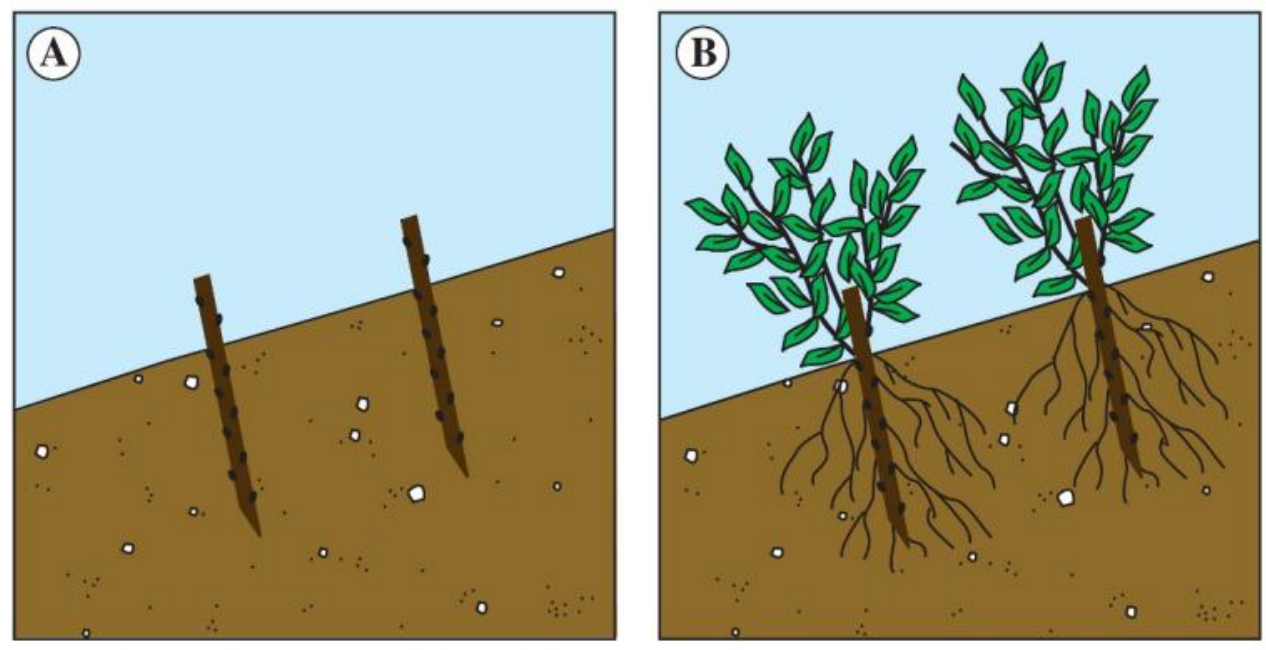

Figure 6.7. Live stake (Illustration courtesy Dave Steinfeld)
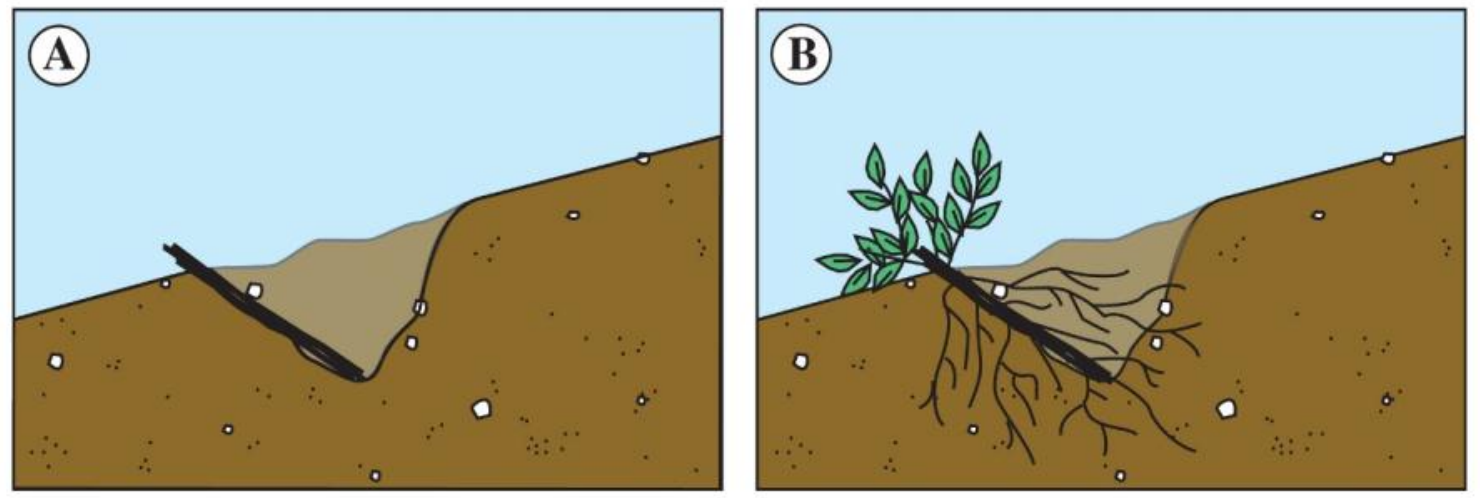

Figure 6.8. Live brush layer (Illustration courtesy Dave Steinfeld)
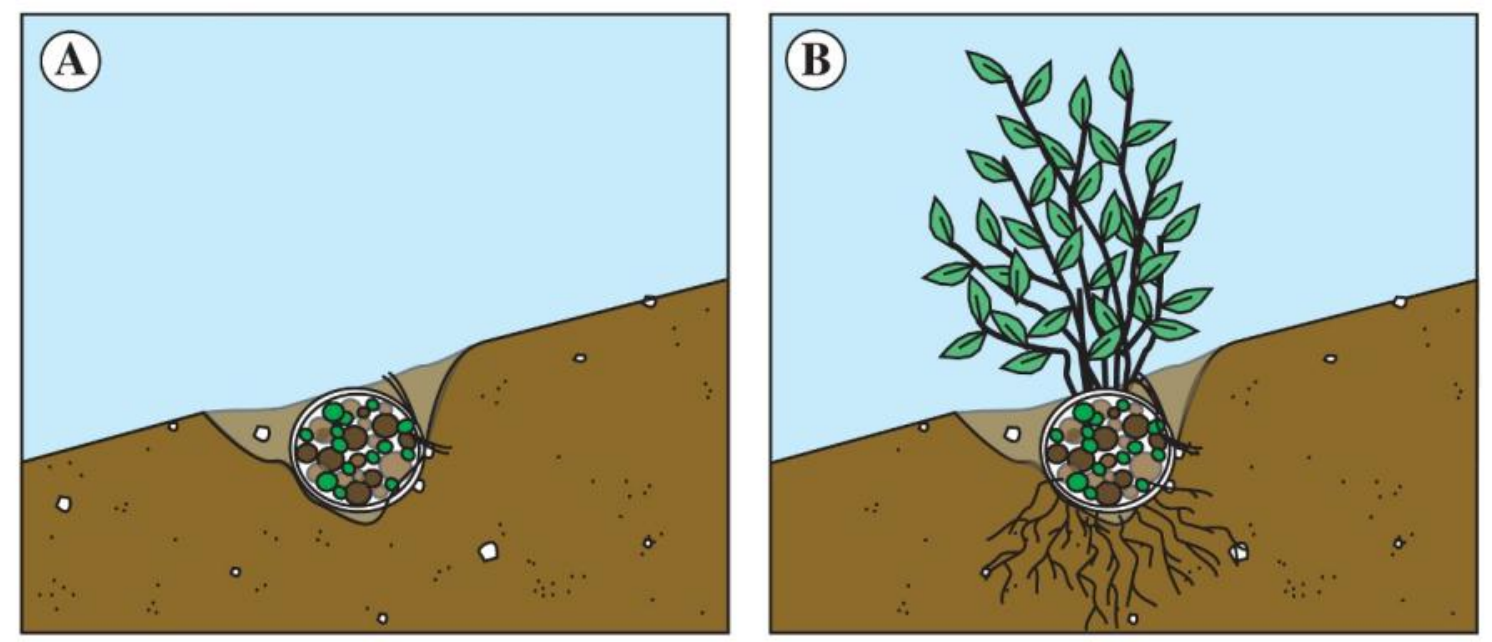

Figure 6.9. Live fascine (Illustration courtesy Dave Steinfeld) 
Erosion mats are installed as sheets covering the soil surface on slopes or as rolled mat bars (Figure $6.10 \mathrm{a}, \mathrm{b})$. Erosion mats must be installed correctly to effectively prevent erosion. Sheet and rill erosion can occur under the erosion mats if they are installed improperly. Seeds must be applied before the erosion mats are installed. For effective use, the soil surface must be relatively smooth to ensure direct contact with the erosion mats. The mats must be trenched into the soil at the upper reaches of the slope in order to ensure soil surface contact.

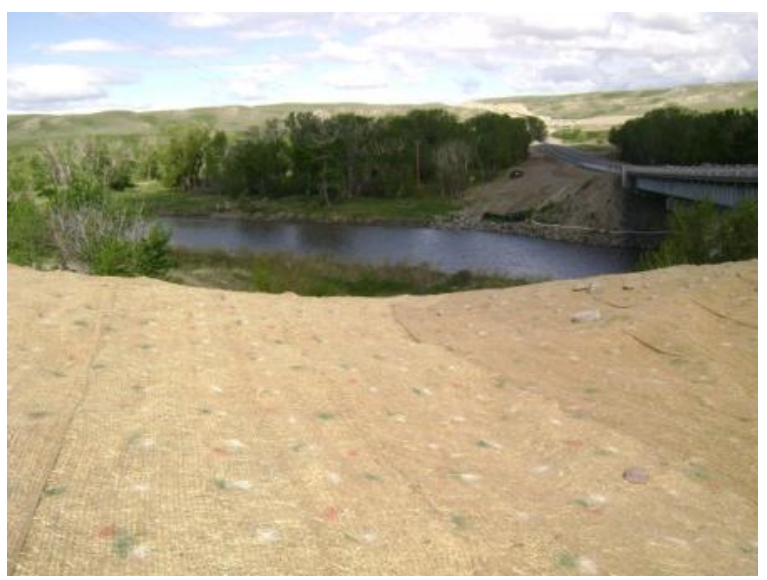

Figure 6.10a. Erosion mat (Photo T. Luna)

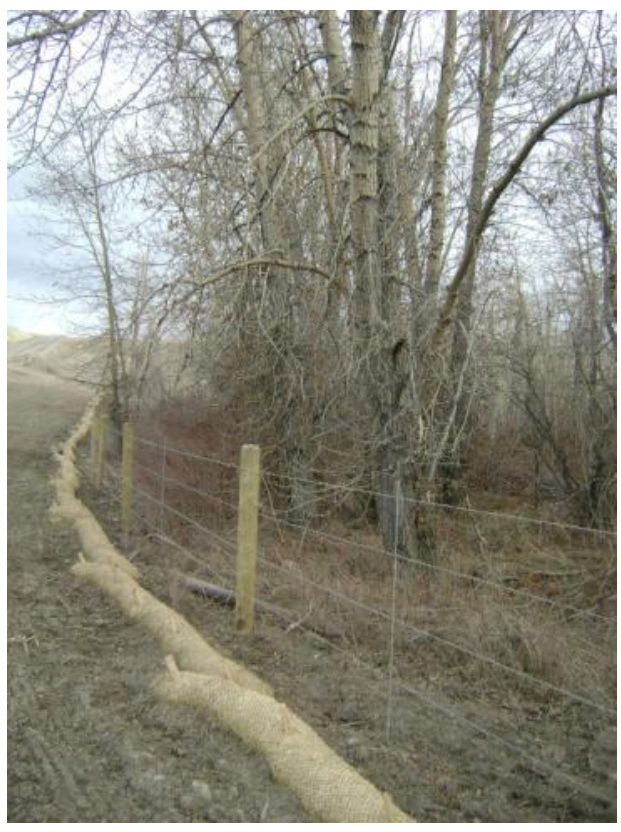

Figure 6.10b. Rolled erosion mat (Photo T. Luna)

\section{Hydromulches}

Hydromulches are applied to stabilize the soil surface and minimize soil erosion. They also can be used to distribute surface soil amendments or seeds. Frequently, hydromulches are used for all three purposes. Hydromulching is limited to areas of the restoration site accessible by road because it is applied using large, heavy tank equipment mounted on trucks. The mixture is referred to as a slurry and contains a tackifier, which binds the surface soil particles with the hydromulch material (Figure 6.11). Frequently, hydroseeding is combined with hydromulching.

Generally, hydromulch consists of wood fiber, recycled paper, or sterilized grass straw (Figure 6.12. Application rates vary depending on the degree or potential for soil erosion and whether hydroseeding is combined with hydromulching. Short fiber material, such as recycled paper, will compact on the soil surface at higher rates of application. This will stabilize soil for longer periods of time; however, it creates a barrier to seed germination. Blended mulches, containing more than one material (longer fiber straw and short fiber recycled paper), are desirable because the mixture of material allows for optimal soil stabilization without compromising seed germination.

Hydromulch is bound to the soil surface with a tackifier. Tackifiers are agents that bind soil particles to the hydromulch material and protect the soil surface from erosion. Tackifiers can be derived from organic or synthetic products. Organic tackifiers are derived from plant-based starches and remain effective for up to 3 months. Organic tackifiers should be used near water sources because they break down into non-toxic compounds.

Hydromulches must be applied during a narrow window of appropriate weather conditions. Hydromulch must be applied when the soil 


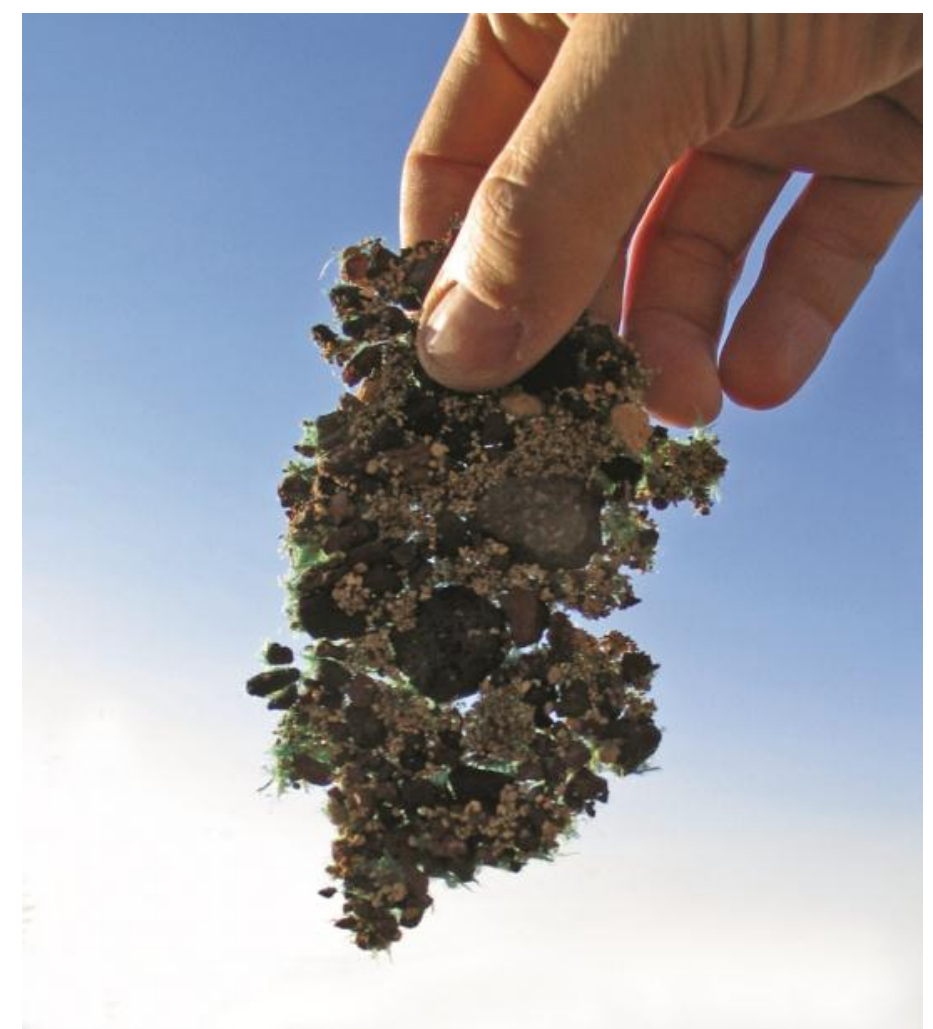

Figure 6.11. Hydromulch (Photo courtesy Dave Steinfeld)

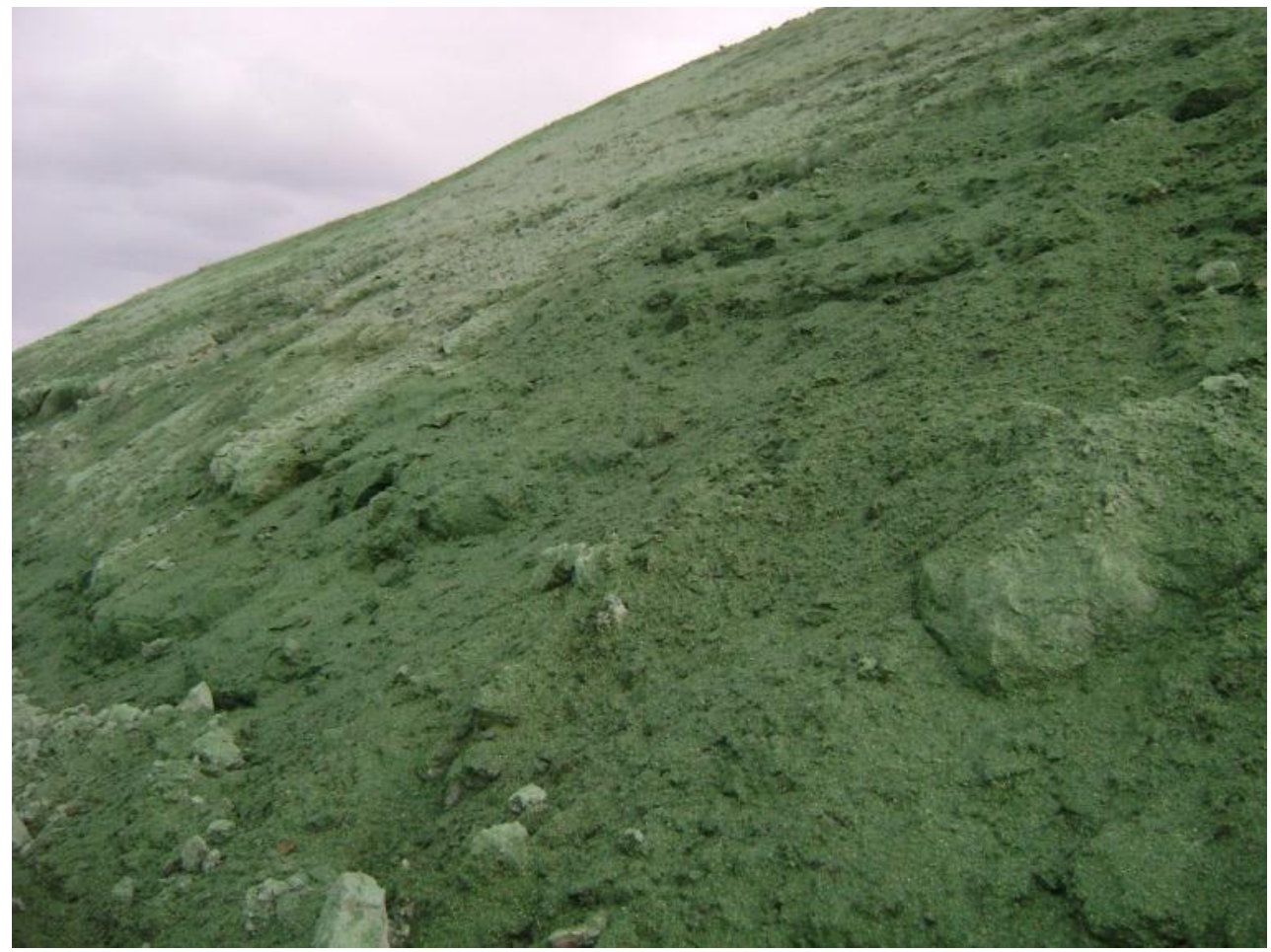

Figure 6.12. Hydromulch along Two Medicine River (Photo T. Luna) 
surface is moist. Following application, the

hydromulch material must dry for at least 1-3 days.

The hydromulch should not be subjected to

freezing temperatures immediately while curing.

\section{Summary}

Hydric soils form in areas subject to frequent inundation. Describing and evaluating soils involves characterizing soil color, texture and structure, including any evidence of compaction. At a coarser scale, evaluation of soils emphasizes soil surface stability. Several factors contribute to soil surface stability, including soil texture, slope length, slope gradient, soil type, flooding events or water input, and existing topsoil cover. Any one or a combination of these factors, if less than optimal, can limit vegetation recovery. Organic matter accumulation will also play a role in restoring wetland function. When soil stability has been compromised, or when soils are compacted, successful restoration will require remediation of soils. 


\section{Chapter 7: Collecting Seeds and Cuttings for Revegetation}

Revegetation needs will differ by site. In some cases, revegetation may be limited to those species that are missing from the existing plant community and have little potential for natural recruitment. Revegetation may also be targeted at decreasing the competitive ability of weeds within the wetland. However, on seriously damaged sites without remnant native vegetation, or upland buffers that were formerly cultivated, complete revegetation may be required. Revegetation efforts require considerable knowledge, planning, and coordination with other concurrent restoration activities.

Because revegetation is both time consuming and very expensive, it is important that the restoration planner, revegetation specialist, and nursery manager work closely to ensure that ecologically appropriate, site-adapted plant material is used. When selecting plant sources, the original restoration goals as well as the identified limiting factors of the project site must be addressed. Revegetation efforts start with the selection of quality, genetically adapted and appropriate seeds, cuttings, or other propagules. This crucial step will have a direct impact on patterns of vegetation recovery, persistence, and sustainability over the short and long term. In this chapter, we discuss important considerations for collecting seeds, cuttings, and other propagules.

\section{Using Genetically Adapted Seed Sources}

Regeneration of wetland plant communities occurs by sexual reproduction through the development of seeds, or by asexual reproduction through clonal propagation by stems, rhizomes, or other vegetative organs. Annuals rely solely on reproduction by seeds, while some submerged aquatic species may only reproduce vegetatively. However, most wetland and riparian species have both modes of reproduction. Seeds represent the greatest potential for genetic diversity and adaptation, and for most purposes, are the preferred propagule collected for revegetation. For restoration and conservation projects, maintaining genetic diversity is usually a key component of the project objectives. By carefully considering the genetic adaptations of the seed or propagule sources, the restoration planner can help buffer a planting against predicted or unforeseen biological and environmental stresses. A population that is currently thriving and reproducing successfully in northern Montana under the prolonged drought of the past 30 years may be expressing some adaptation to these changes, and therefore would be more desirable as a seed or cutting source than sources located in the mountains or foothills of western Montana.

The genetic source of seeds can be a major factor in the success of a restoration project. Selection of seed sources should emphasize seed quality and genetic adaptation. Seed quality is largely determined by the population size and biological health of the local population, and by the environmental conditions during the growing season that influence seed formation, maturation, and production of viable embryos. Environmental conditions also contribute to the quantity of seed produced from year to year, and can have some influence on the degree of seed dormancy exhibited by a population. Careful consideration I $n$ selecting seed sources can foster plant populations that are well adapted to local site conditions and better suited to achieving project goals. We strongly recommend using local sources to maximize local adaptation and 
and prevent outbreeding depression, but in highly modified landscapes, this restricts collection to small remnant populations where quality seed sources may be limited. In these cases, the restoration planner should collect from a wider geographic area. Broad genetic representation is key to ensuring future adaptability. Long-term ecological viability can best be ensured by selecting appropriate plant and seed sources, representing enough genetic diversity that they can remain resilient to environmental stresses.

The short- and long-term impacts of genetic seed quality warrant careful consideration of how populations are selected as seed sources (Dumroese et al. 2009). Populations of a given species that are healthy, reproducing, and occupying edge environments of their habitat may exhibit greater genetic diversity and thus may contribute even greater potential for adaptability to environmental changes. Populations existing on the drier edge of their preferred hydrological zone in a wetland, for example, may contain greater genetic diversity and genetic characteristics adapted to this drier hydrological regime. These would therefore be a desirable seed source when planting a shallow wetland that is subjected to prolonged periods of drought or increasingly longer periods of drawdown.

Falk (1990) suggests that in many plant populations, collecting seeds of $10 \%$ of the population captures $90 \%$ of the genetic diversity. To adequately capture genetic diversity, the following guidelines should be considered when collecting seeds:

1. Collect seeds from as many individuals as possible. In fragmented landscapes, seeds should be collected from as broad a geographic extent and as many locations as possible, including the periphery of a species' geographic range and edge environments within its habitat.
2. In small remnant stands, collect seeds from a minimum of 30 individual plants. If the species is rhizomatous or mostly clonal, extra effort will be required to locate 30 individuals. Small collections from less than 30 individuals should be restricted to species that are locally uncommon.

3. Collect a few seeds from as many individuals as possible to ensure a good genetic representation of the population and to prevent the representation of only a few genotypes at the restoration site.

4. To ensure genetic adaptation, collect seeds to the extent possible from habitats similar to the restoration site in terms of plant community associations, elevation, hydrological period, and soils.

5. Use methods and tools that minimize damage to the plants and habitat.

6. Collect relatively even amounts of seeds from each individual so that no single individual is over-represented in the collection.

\section{Applying Plant Ecology Principles to Seed Collection Efforts}

Wetland and riparian plant species are uniquely adapted to their environments and have evolved seed morphological features, seed dormancy, and dispersal strategies that reflect the abiotic and biotic influences that shape these environments. Most wetland species have inconspicuous flowers and fruits; they can be difficult to identify. Qualified seed collectors must be able to positively identify species and recognize fully mature fruits and seeds. This will allow the collector to time the collection correctly, and to make other important decisions regarding seed sources.

Wetland and riparian plants are represented by a few plant families that are taxonomically challenging, the grass, sedge, rush, and willow families. Additionally, there are several plant families that are only found in wetland 
communities, many with inconspicuous flowers, fruits, and seeds. Floating leaved and submerged species exhibit flowering or fruiting structures that mature below the water level, making them more problematic to monitor and collect compared to upland or emergent species. Collectors must have the ability to positively identify the species and develop collection methods, tools, and strategies that yield a quality collection of seeds.

Careful timing of seed collection influences both seed quality and quantity, capitalizing on the window of opportunity when seeds are fully mature but before dispersal occurs (Figure 7.1). Thus, it is important to be familiar with the dispersal strategy of the species of interest. Fruits of wetland seeds exhibit highly specialized structures that aid in protection and dispersal of seeds. Water, wind, and wildlife are the primary dispersers of seeds, and many species can be successfully dispersed by all of these means. Some species, such as sedges (Carex), have seeds enclosed in air-filled or papery sacs that aid in wind and water dispersal. Other species have buoyant seeds or fruits that float on the water. Still others have appendages to the fruits or seeds, such as hairs, barbs, or wings.. An understanding of the dispersal strategies and morphological features of the fruits and seeds will assist the collector in developing effective collection methods and tools.

Seed collectors also need to be able to distinguish fruits and seeds of species that they are collecting to ensure collection of fully mature seeds. In some species, what appears to be a seed is actually a thin walled fruit containing the seed. Collectors must also be able to distinguish mature seeds from immature, unfilled, or aborted seeds. During periods of environmental stress, plants may flower and fruit but fail to produce viable (filled) seeds containing an embryo capable of germination. Collecting non-viable seeds can seriously impact revegetation efforts, adding to costs and delaying results. Protocols describing mature viable seeds,

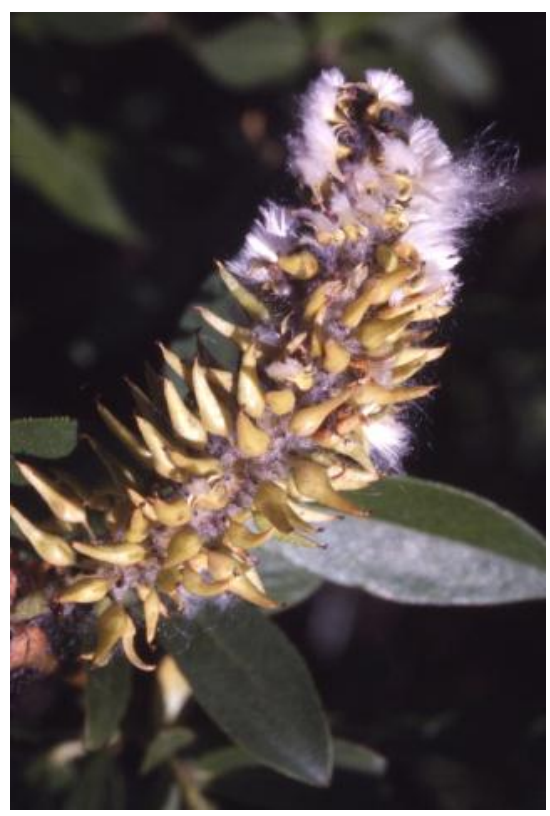

Figure 7.1 Mature seeds of Salix lutea prior to dispersal (Photo T. Luna)

Seed maturity dates, and quantities for common species can be found in Tables 1-4 at the end of this chapter. Collectors also can refer to the photo guide of mature, viable seeds of common emergent species in Figures 7.2a-g.

To ensure correct identification, voucher specimens should be collected, identified and verified by expert botanists prior to seed collection. Species should be identified to the subspecies level whenever possible. These efforts will prevent pollution of local gene pools or the spread exotic species.

\section{Monitoring for Seed Collection}

To time seed collection correctly, the desired seed sources must be monitored over the course of the growing season. Viable, healthy, and reproducing populations should be located early in the growing season, preferably when plants are in flower or beginning to form fruit. The collector may need to 


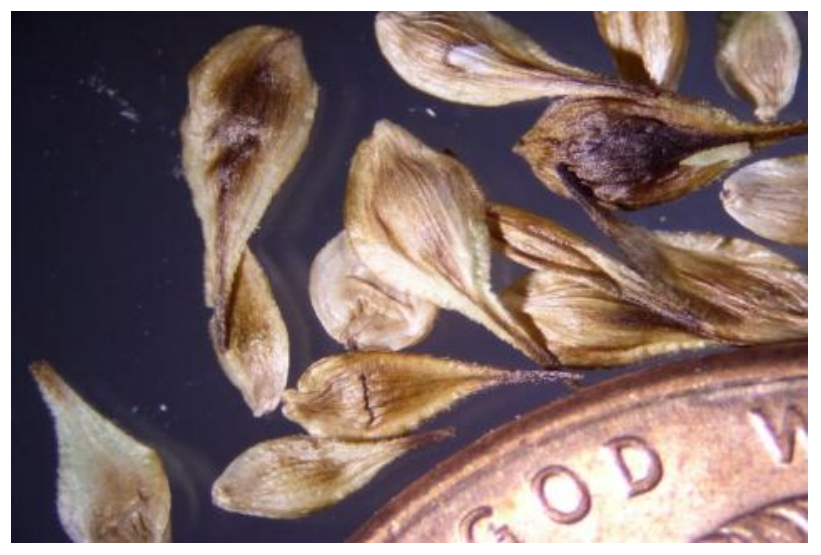

Figure 7.2a. Carex microptera; (J. Scianna, NRCS)

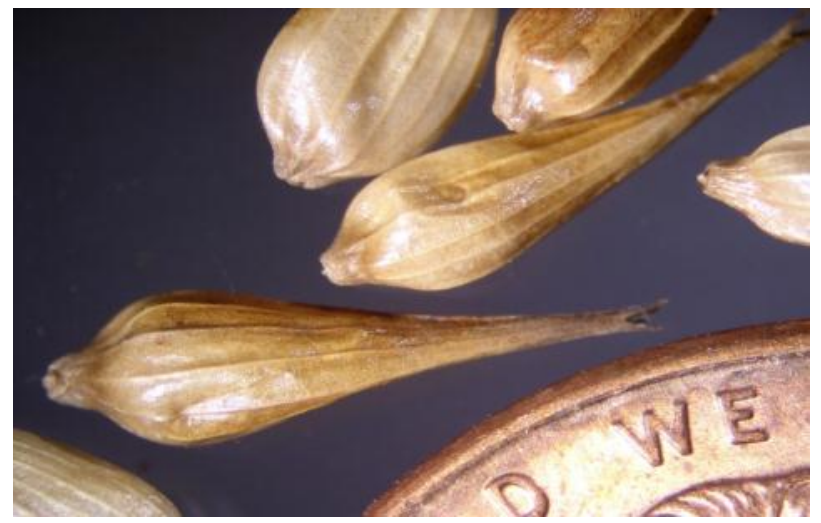

Figure 7.2b. . Carex vesicaria (J. Scianna, NRCS)



Figure 7.2c.. Schoenoplectus acutus (J. Scianna, NRCS)

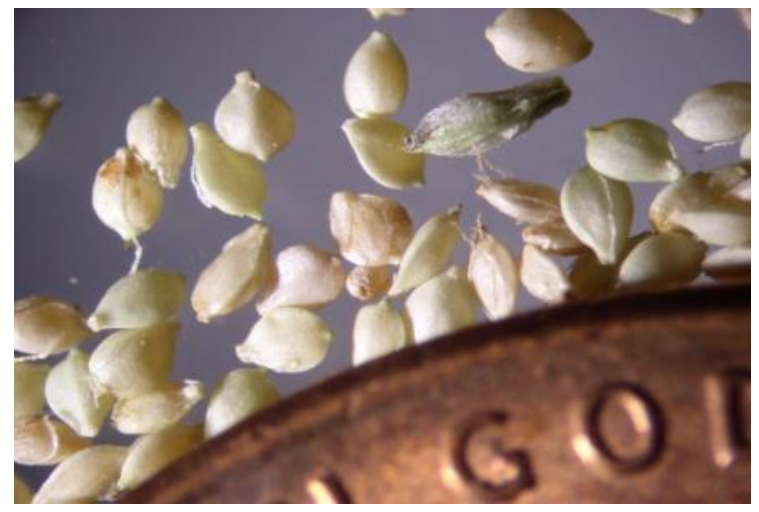

Figure 7.2d. Scirpus microcarpus (J. Scianna, NRCS)

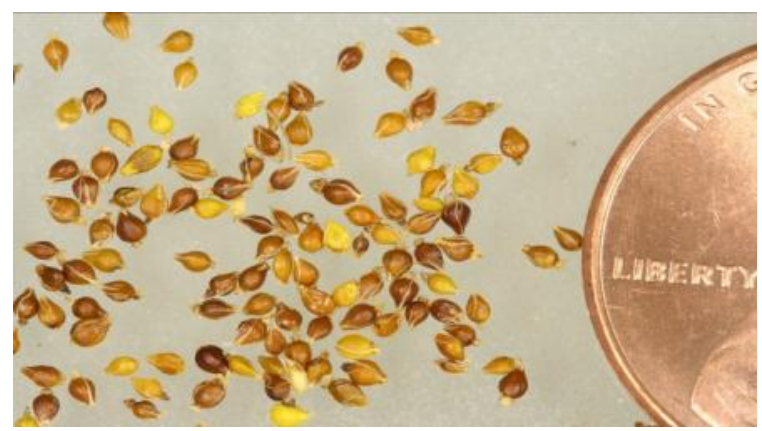

Figure 7.2e. Eleocharis palustris (J. Scianna, NRCS)

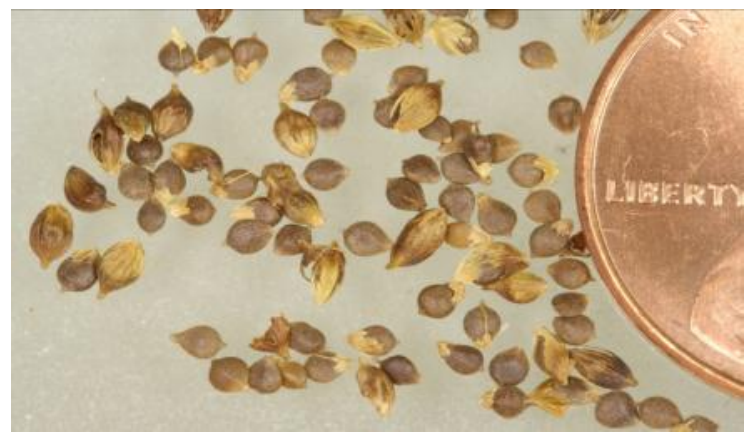

Figure 7.2f. Carex nebrascensis (D. Tilley, NRCS)

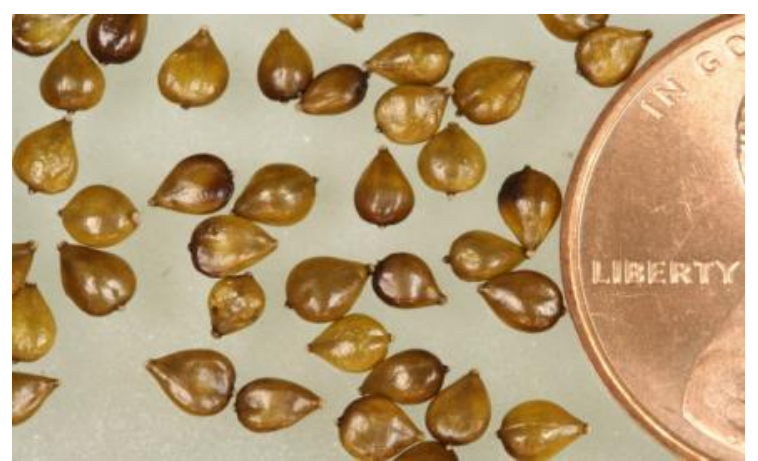

Figure 7.2g. Schoenoplectus maritimus (D. Tilley, NRCS) 
make several visits to monitor the population as seeds approach maturity. At this stage, the collector should take several seed samples and perform a cutting test to determine seed quality and seed fill. Recording dates of flowering, fruit set, and seed maturity will help the collector plan future seed collection efforts. Most developing fruits become visible only a few weeks after flowering and pollination.

Environmental factors during the growing season play a key role in timing of flowering, pollination, seed maturation, and even the degree of seed dormancy exhibited by the seed collection. S udden frosts during flowering can completely negate seed production for that year. Prolonged periods of cool weather and rain will limit wind pollination and/or pollinator activity, resulting in greatly limited seed production. Cool, wet weather can also slow the rate of seed maturation. Drought and high temperatures may promote flowering, but prolonged moisture stress may cause some plants to abort developing fruits and seeds. In cases where fruits do develop, overall seed viability may be low or seeds may be unfilled. This is why it is important to perform a cutting test on seeds just prior to collection.

\section{Performing a Cutting Test Prior to Seed Collection}

Cutting tests are needed to determine the maturity stage of seeds and their viability. They also allow inspection for abnormal, infested, or empty seeds. Several seeds from several individuals within the stand should be examined. The collector will need a hand lens and razors, knives, or scalpels for cutting. The fruit or seed is cut along its longest axis. The collector will need to inspect the seed for its internal coloring, how completely it fills the seed coat cavity, and presence of an embryo. Depending on species, the embryo may completely fill the cavity or be tiny and embedded in the endosperm. A microscope is useful for examining very small seeded species.

If the seed coat is soft and the contents are watery and soft, the seed is still immature and incapable of curing, storage, and germination. If the seed coat is hard and the contents are firm and light tan to white in color, the seed is approaching maturity or is fully mature; however, some submergent species will have soft seed coats. Some species can be collected just prior to maturity if the entire inflorescence is cut and the seed is allowed to cure properly before cleaning.

An optimal time for collection is when the fruits or spikelets are just beginning to spread open at the top. For sedges, rushes, spike rushes, bulrushes, and grasses, seeds can be collected by hand stripping the fruiting stems. It is important to use a hand lens to examine seeds for maturity and fill. Filled, ripe seeds will shatter or easily shake out of the seed head so they must be held upright during cutting so that the seeds do not fall out. Because many of these species have tiny seeds, it is important to use paper bags that have seams reinforced with tape to prevent seed loss.

Determining the amount to collect will depend on seed size, seed quality, and how many nursery plants are desired for planting. For example, one gram of good quality rush (Juncus) seeds can produce 4,000-5,000 nursery seedlings (Dumroese et al. 2010). When collections are direct seeded on the restoration site, the total seeding rate and acreage will determine the quantities that must be collected.

\section{Temporary Storage and Handling of Seed Collections}

Handling of seeds and fruits at each step from collection to storage directly affects seed quality, viability, and temporary or long-term storage life. Wetland and riparian plant species exhibit both 
both recalcitrant and orthodox seeds. Recalcitrant seeds are those which retain viability for a few days, weeks, or months, but generally less than one year. Examples include willow (Salix), cottonwood and aspen (Populus), and many aquatic, submergent, and emergent species. Species that have very small seeds with thin seed coats or species that inhabit zones of permanent or semi-permanent saturation often have recalcitrant seeds. Recalcitrant seeds must be sent to the nursery immediately or they must be immediately sown on the restoration site. Generally, seeds must be kept moist and not allowed to dry below a critical level of seed moisture content before use.

During temporary storage before sowing, recalcitrant seeds must be kept fully hydrated by keeping them in trays under moist burlap bags or in plastic bags filled with moistened sand or coir at cool temperatures. Relative humidity should be maintained at $80-90 \%$. Just prior to sowing, seeds are usually soaked in water for a few hours to a few days, depending on species. Techniques have been developed to increase seed storage life of recalcitrant species, but generally, seed viability is still limited to 2 years.

Orthodox seeds are those that store easily for long periods and can tolerate desiccation. The majority of temperate upland and some wetland species fall into this category. Orthodox seeds retain viability for periods longer than a year and can be dried to low moisture levels and stored under lower temperatures. Species that grow in areas that are seasonally unsuited for germination usually produce orthodox seeds. Dry, hard seed coats are most likely to be orthodox seeds. This includes many species of trees, shrubs, grasses, and forbs in temperate climates in a wide range of habitats, including some species from wetland and riparian areas. Examples of species with orthodox seeds include hardstem bulrush (Schoenoplectus acutus), water plantain (Alisma species), American licorice (Glycyrrhiza lepidota), western snowberry (Symphoricarpos occidentalis), and redstem dogwood (Cornus sericea). Many of these species can be successfully dry stored for 10 years or longer (Dumroese et al. 2011, Hoag 2010).

Species in a given family can vary in the expression of recalcitrant or orthodox seed behavior. Some wetland sedge (Carex) species have seeds that are recalcitrant and require storage in water. In seed tests, seeds that were stored under moist conditions or in water consistently germinated to higher percentages than seeds that were held in dry storage (Comes et al. 1978, Budelsky and Galatowitsch 1999). Dry storage of seeds appears to be detrimental for some sedge species (Comes et al. 1978, Budelsky and Galatowitsch 1999, Van der Valk et al. 1999). In contrast, Nebraska sedge (Carex nebrascensis) and Northwest Territory sedge (Carex utriculata) are species that can be dry stored for up to 5 years and 2 years respectively without significantly impacting high germination rates (Jones et al. 2004, Hoag 2010). These species typically occupy the drawdown zone and are therefore adapted to some level of seed drying.

Whether the species has recalcitrant or orthodox seeds influences the way seeds are handled during and after collection. Recalcitrant species require cool temperatures to prevent immediate germination and maintenance of seed moisture content during collection, temporary storage, and shipment. Conversely, seed collections of orthodox seeds must be handled in such a way to prevent moisture build-up during collection, transport, and temporary storage. Freshly collected fruits and seeds, whether they are dry or fleshy, have high moisture content and will mold if stored inappropriately, even for a few days. Post-harvest drying reduces the moisture content of fruits and seeds, helps open dry fruits, and prepares orthodox seeds for further cleaning (Figure 7.3). Collections should be placed loosely in paper bags to allow 


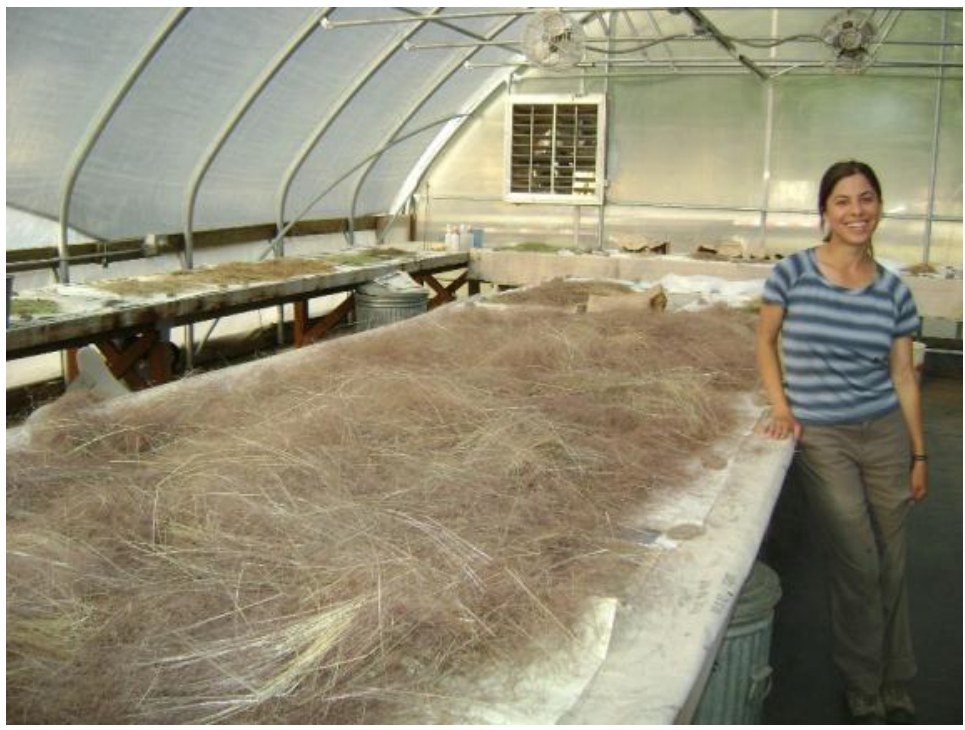

Figure 7.3 Post-harvest drying of orthodox seeds (Photo T.

Luna)

allow some air circulation during shipment. Seeds that are not shipped for further cleaning and processing must be spread out evenly on a drying rack in a dry, temperature-controlled building immediately after collection. Dry fruits and seeds are placed on a mesh screen with fine holes that allow air movement to promote even drying and eliminate moisture buildup, but prevent seeds $\mathrm{f}$ rom falling through the screens.

Fleshy fruits require slightly different handling, transport, and temporary storage. Heat buildup and fermentation can damage seeds within the fruits. It is important not to let the fruits dry out, since this can make cleaning more difficult. Fleshy fruit collections can be placed in plastic bags in a cool place or in a refrigerator until they are processed and cleaned (Figure 7.4).

\section{Considerations When Using Commercial Seed Sources}

Using commercial seed sources for restoration purposes requires very careful decisions

(Dumroese et al. 2009). High quality seeds that are weed free are critical whether you are growing seedlings in the nursery or reseeding a restoration site with native grasses and forbs. All commercial native seeds have a certificate of the seed analysis for each seedlot. The seed analysis from the producer must have the name of the species and cultivated variety (if applicable). It is also important to obtain information on the origin of the seed, an estimate of viability, the percentage of pure live seed, and the percentage of other crop

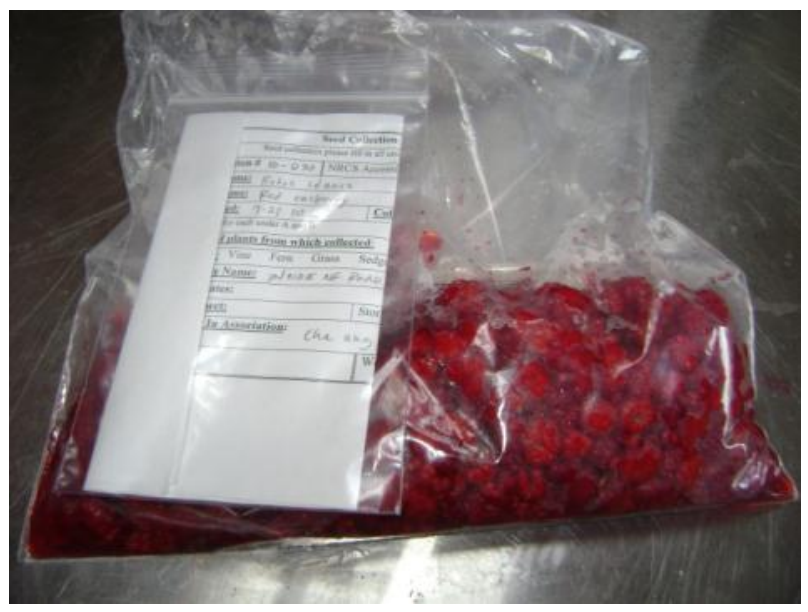

Figurre 7.4. Temporary storage of fleshy fruits (Photo T. Luna) 
crop seeds, weed seeds, and inert material. Name and origin of the species can be important to ensure that you are purchasing a site-adapted source. It will be important to obtain information on the original location of the source. If local sources are not available, the restoration planner will need to locate a source that is in a similar ecological zone.

Native cultivated varieties are available for some native grasses and forbs, and are shown on the seedlot tag following the scientific name as a "named" variety. Cultivars are developed by selecting individual plants that undergo further selection for traits that allow for economical seed production. Most of the grass cultivated varieties, for example, have been developed from seed sources from upland communities and exhibit traits such as competitive ability, ease of germination and establishment, and stress resistance. How adaptable these varieties are to wetland boundary environments is unknown.

The restoration planner will need to carefully consider the implications of using cultivated varieties when local, wild sources are unavailable. Highly competitive strains and selections of native species can pollute local ecotypes, interbreed and displace native populations (Bischoff et al. 2010). If preserving and maintaining local genotypes of the community is a long-term goal, cultivated varieties are not an option. Cultivated varieties are commonly used in upland buffer restoration plantings, when hundreds of pounds are required for reseeding.. Because watershed scale restoration projects occur over a several year period, every effort should be made to collect local sources for seed to preserve and maintain local genetic populations, native species composition, both for wetland and upland buffer plantings.

Percentage germination reports the germination potential of the seed at a particular point in time. This is usually described as the percent germination of 100 seeds that germinate between 0 and 21 days. Many native species do not germinate within that time frame. Instead, they are tested with dye (tetrazolium) to determine the amount of living seeds. The percentage pure live seed (PLS) is a seed quality index that is calculated following seed testing. The percentage pure live seed is the basis for comparing seed lots that differ in purity and viability. Most commercial seed lots typically have high PLS values.

The seed label of commercial seeds will also list the percentage of weed seeds or other inert material. Seed lots must have very low percentages of weed seed and other inert materials. The restoration planner can ask the seed supplier about where the species was grown and what potential weed seeds may be present in the seedlot. Similarly, restoration planners should never purchase generic "wildflower seed mixes" for use in a restoration project. These mixes may include species that were originally growing in another area of the country or species that are not even North American in origin Some marketed mixes can contain noxious weeds such as ox-eye daisy (Leucanthemum vulgare) or purple loosestrife (Lythrum salicaria), or other aggressive species.Restoration planners should purchase only native forb seed lots from reputable seed dealers that can guarantee the positive identification of the species, and the origin of the seeds. Native forb species should be purchased individually and mixed by the restoration planner or specialist rather than relying on the seed company.

\section{Using Vegetative Propagule Sources}

Vegetative propagules are primarily used in restoration if: 1) the species can be easily and more economically established by using cuttings or other vegetative organs rather than seeds; 2) seeds are difficult to obtain or collect; or 3 ) it is the only means means of reestablishing the species. 
Vegetative propagation also may be the only method of maintaining the local genotypes of a species. The vast majority of species that inhabit wetland and riparian environments in Montana exhibit both sexual reproduction by seeds and asexual reproduction through the production of vegetative organs capable of developing into individual plants. Thus, all new daughter plants that arise from vegetative reproduction are genetically identical to the parent (donor) plant, and these resulting individuals are known as clones. Stems, shoots, root sections, rhizomes, stolons, vegetative buds, tubers, and stem fragments can be used as sources of clonal plants. These can be collected from natural populations and can also be used as a source for increasing plants at a nursery.

\section{Collecting Dormant Hardwood Cuttings for Riparian Restoration Projects}

Dormant hardwood cuttings are woody stem sections that can develop into new plants complete with stems, leaves, and roots. Cuttings can be long or short, depending on how they are used. For most riparian restoration projects, cuttings are collected from woody plants on the site during the winter "dormant" period. The ability of a species to regenerate roots varies widely among species. However, prevalent species found in riparian and floodplain communities have special adaptations to develop roots following breakage from the parent plant. Some species such as willow and cottonwood are capable of regenerating roots due to the presence of numerous latent root initials within the stem tissue. Generally, dormant hardwood cuttings root more easily and have more stress resistance. In order to collect dormant hardwood cuttings, the collector must be able to correctly identify the species and collect healthy stem wood complete with intact dormant leaf buds. Procedures for collecting dormant hardwood cuttings are described below.

\section{Types of Cuttings}

Dormant hardwood cuttings can be collected for two stock types: they may be planted in the riparian project as "non-rooted cuttings", or sent to a nursery to be rooted, grown for a year, and then outplanted on the project site as "rooted cuttings". Generally, there are three types of non-rooted cuttings: live stakes (12-16 inches long), pole cuttings (12-16 feet long), and branched cuttings (2-6 feet long) (Figure 7.5). These are used to construct fascines and other bioengineering structures. If rooted cuttings are required, the restoration planner will need to determine the stock type size and work with the nursery facility to plan when the material will be ready for planting. Typically, a nursery can produce a 10-20 cubic inch rooted cutting in 2-4 months.

Larger stock types take longer to produce, but are usually ready the following spring .

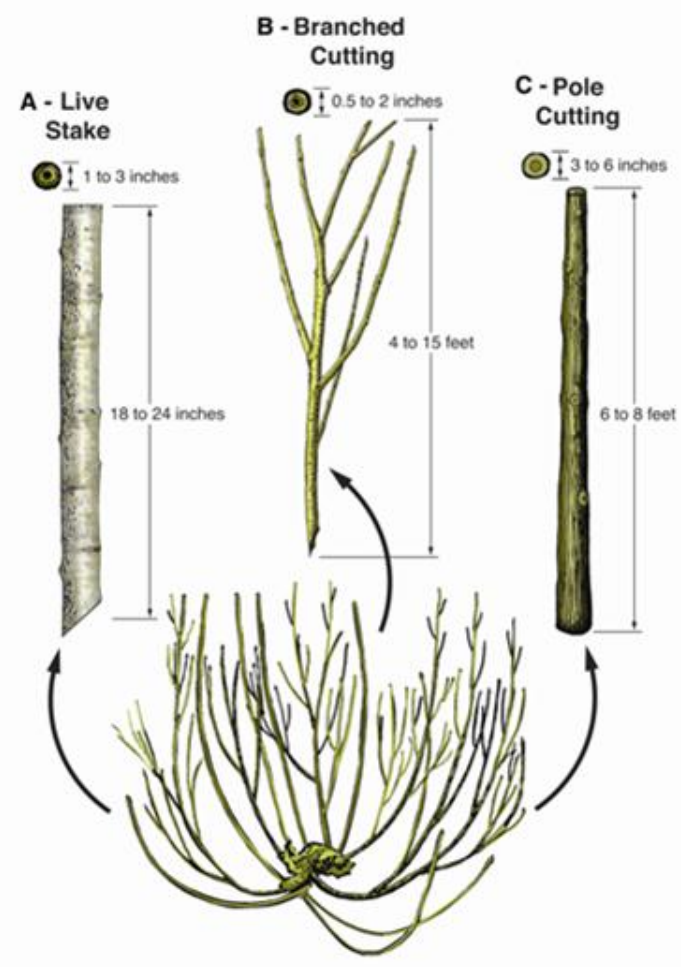

Figure 7.5. Branched cutting (Illustration courtesy $\mathrm{T}$. Landis) 
Good cutting material, regardless of size, will always consist of healthy stem tissue with some intact buds, and with enough stored food reserves in the stem tissues to sustain it until new roots are formed. Collectors will need to carefully inspect each potential donor plant to ensure that it is healthy. Cuttings should not be collected from donor plants that are dying or are obviously infected with disease or insects. Some common pest symptoms include brittle or blackened stems, shrunken areas on the stem tissue, and tumor-like growths (insect galls). The age of the wood also can influence rooting success. Stem sections from the previous year's growth are ideal. "Juvenile" wood is found near the stem base or root crown as long, nonflowering shoots (sucker shoots), which root better than those collected from older mature wood (Figure 7.6). Finally, when collecting willow or cottonwood cuttings, the collector must determine if both sexes are represented in the local population. Willows and cottonwood are either male or female, so cuttings should be taken from both if one objective is to develop a self-sustaining plant community over the

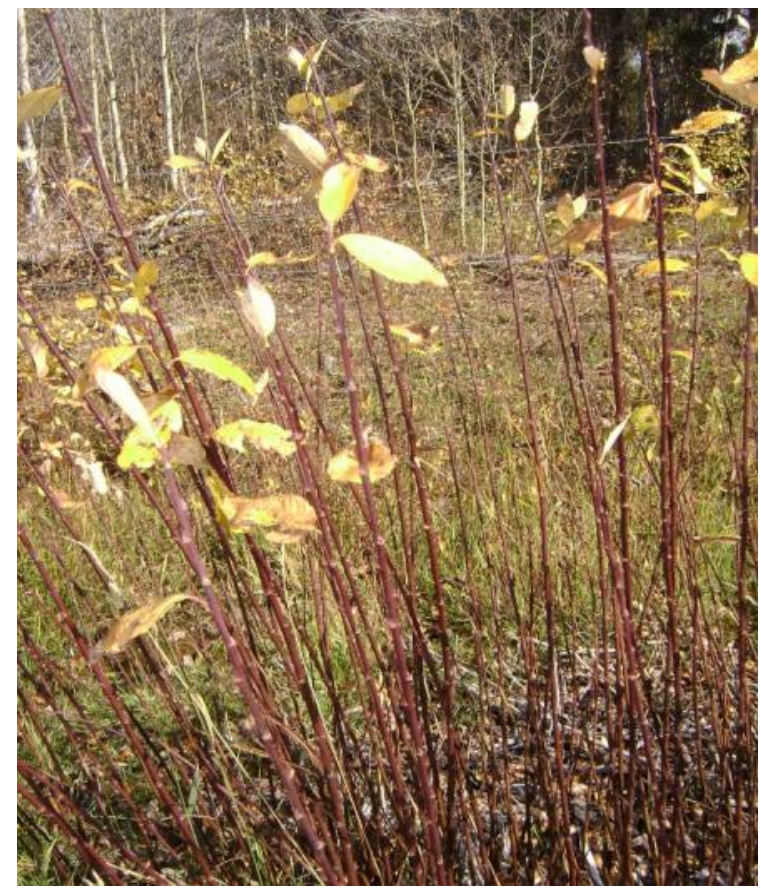

Figure 7.6. Juvenile Salix (Photo T. Luna) long term. Determining sexes between individuals is discussed in more detail later in this chapter.

\section{How to Collect Dormant Hardwood Cuttings}

Because cuttings are genetically identical to the donor plant, it is important to consider the following in order to maintain an adequate representation of genetic diversity (Luna et al. 2006):

1. Locate a harvest site and obtain permission to collect cuttings. Because species identification is easier when leaves and flowers are present, try to establish collection areas in the spring or summer. If uncertain about proper identification, collect a sample for later confirmation.

2. Collect a few cuttings from at least $25-30$ individuals scattered over the project site. A general rule of thumb is that $10 \%$ of the overall population captures $90 \%$ of the genetic diversity. It is important to keep in mind, however, that locating at least 30 individuals can be problematic. Many willow or cottonwood stands can be largely clonal in a given area.

3. Use sharp, well-maintained shears, hand pruners, hand saws, and pole pruners to make clean cuts. The cutting surfaces of tools should be cleaned with a disinfectant such as rubbing alcohol to prevent the possible transfer of bacteria or fungal spores.

4. Clip cuttings with leaf buds near the top of each cut line. Avoid stem sections with flower buds. Flower buds typically occur at the tips of branches produced during the last growing season.

5. For live stakes and pole cuttings, select branches 0.5-2 inches in diameter and at least 5 feet long. If necessary, branches can later be cut to a shorter length. The potential for drying during storage is reduced when the cuttings are stored in longer sections ("whips")..

6. All cuttings, regardless of size, must have some leaf buds present on the stems so that the cutting can manufacture food during rooting. For smaller cuttings, especially those destined for a nursery, the stem cutting must include at least 2 nodes.

7. It is critical that all cuttings be outplanted with 
correct orientation. To mark the top of the cutting, make a straight cut at the narrow end (toward the tip). At the thicker end (toward the base), cut the branch at an angle, so that it makes a point . This will insure that cuttings will be oriented properly, and also makes them easier to plant. After harvesting from a donor plant, either trim the branches flush with the main stem or make a right-angle cut just above a leaf node. This will aid in healing.

8. Dip the top (blunt cut, narrow end) of the cutting in wax immediately after cutting. The wax not only marks which end is up, it also seals the exposed cut end to prevent drying and cracking. Collectors may want to use a drop of paint of different colors to color code different species of cuttings, and other treatments. The paint dot will also make the stakes more visible once they are planted so people won't trip over them.

9. Place all cuttings in the same direction in the bundles. This will prevent the wrong end being planted in the ground. Cuttings should be kept moist by either wrapping them in wet burlap or placing them in buckets with water until they are transported back to the nursery cooler. Cuttings may be tied in bundles with colored twine for ease in identification and carrying. Label each bundle with species, date collected, number of cuttings, and harvest location.

10. To maintain safe conditions, avoid leaving sharp stumps, especially in areas that are frequented by wildlife or people.

\section{Storing and Handling Dormant Hardwood Cuttings}

Cuttings are living tissues that are highly perishable. Ideally, non-rooted, dormant cuttings for live stakes, poles, or branches for bioengineering should be collected just before installation on the project site. With proper collection and storage, however, hardwood cuttings can be stored for several weeks. If they can't be planted immediately, cuttings should be stored under refrigeration. Some revegetation specialists advocate soaking bundles of cuttings in running water for several days to completely hydrate them prior to installation.

When collecting material for rooted cuttings during freezing weather, keep bundles as cool as possible and out of direct sunlight. Dormant cuttings can be stored at temperatures down to $0^{\circ} \mathrm{F}$ without damage. Adding snow to stored bundles helps prevent excess drying. If temperatures are above freezing and especially during sunny weather, cuttings should be refrigerated at $34-40^{\circ} \mathrm{F}$ and $60-70 \%$ humidity (Luna et al. 2006). Some collectors wrap hardwood cuttings in moist peat moss or wet burlap before placing them into refrigeration, whereas others use wet sand. It is important to monitor the condition of stored cuttings to detect problems such as drying, sprouting, or mold.

Proper handling is important when preparing cuttings and during field installation. Cuttings will need to be kept cool and hydrated until they are planted. Discard any cuttings that have molded, sprouted, or appear brittle and dry. Soaking stored cuttings in water for 24-48 hours can improve survivability, especially if the weather is windy and/or warm at the restoration site. Cottonwood live stakes and pole cuttings may root better when treated with a low concentration $(1,000 \mathrm{ppm})$ of liquid rooting hormone prior to outplanting. On site, the cuttings should be stored away from direct sunlight, heeled into moist soil, or stored in water until planting.

If a spring project is delayed or rescheduled for fall, do not attempt to store cuttings in cooler storage for a prolonged period of time. Cuttings are living tissues and have a finite shelf life. It's much more effective to collect new hardwood material again when plants go dormant in the fall, to ensure that healthy material capable of regenerating roots and shoots is used on the restoration project site. 


\section{Considerations for Collecting Willow and Cottonwood Cuttings}

Cottonwoods and willows are important components of riparian areas, and will feature in most restoration strategies. However, it is necessary to correctly distinguish cottonwood saplings from willows. The two genera are distinct from one another in flower structure, pollination biology, flowering phenology, and frequency of natural hybrids. Using several taxonomic references and frequent field visits, the restoration planner and revegetation specialist can become familiar with the distinguishing characteristics, the hydrological zones the species occupies, and the degree of variability exhibited by each species. By becoming familiar with floral and vegetative buds and male and female buds, the revegetation specialist can collect hardwood cutting material of both sexes with ease and locate female trees for seed collection. These efforts will also ensure that the material collected is from a native, naturally occurring willow or cottonwood species.

\section{Flowering and Fruiting Characteristics of Cottonwood and Willow}

Willows and cottonwoods are woody trees, shrubs, or subshrubs that are characterized as being dioecious, with male and female flowers being borne on separate plants. Only in rare instances have hermaphroditic flowers or monoceious individuals been observed (Rowland et al. 2002). The numerous, minute, and imperfect flowers lack sepals and petals but are subtended by a bract and are borne in pendulous or upright unisexual male or female catkins. Male flowers have from 2-30 free or united stamens. Female flowers consist of one pistil with 24 carpels containing numerous ovules.

Cottonwoods and willows are differentiated from one another by flower structure, flowering phenology, and pollination strategy. Cottonwoods produce scentless flowers that are borne in pendulous catkins that are entirely wind pollinated (Figure 7.7a,b). Nectaries are absent, but there is a gland of unknown function at the base of each flower. Flowering is precocious in all cottonwood species, so hybrids between cottonwood species occur more frequently in nature than hybrids between willows.

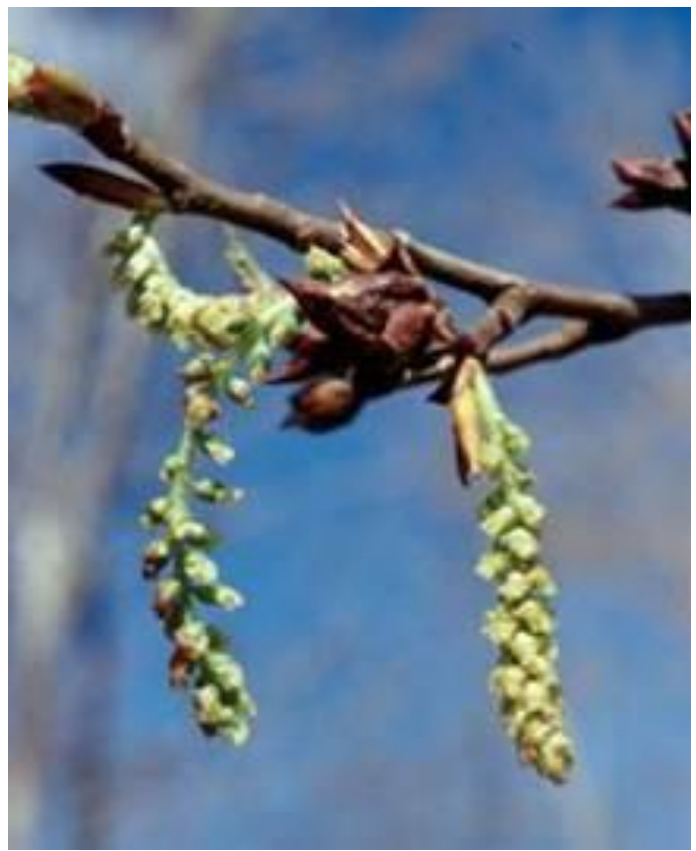

Figure 7.7a. Populus catkin, female (Photo courtesy T. Landis)

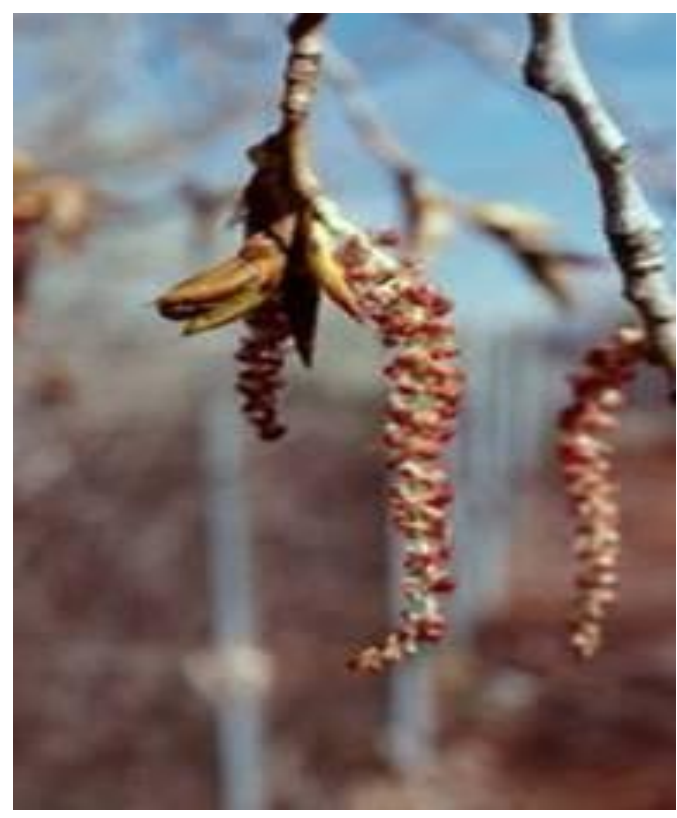

Figure 7.7b. Populus catkin, male (Photo courtesy T. Landis) 
Willows produce upright, rigid catkins (Figures $7.8 \mathrm{a}, \mathrm{b})$. Both male and female flowers have one or two nectar-bearing glands at the base of each flower. Insect pollination is predominant among willows, although some pollination can also occur by wind. Depending on species, catkins appear before leaves (precocious), at the same time as the leaves (coetanous), or after the leaves emerge (serotinous). Because there is more variance in flowering phenology among willow species, hybridization does not occur frequently. Hybridization is mostly limited to closely related species that exhibit the same range, habitat, elevation distribution, and flowering phenology (Argus 1965, Brunsfeld and Johnson 1985, Dorn 1974). Although most plants are dioecious, hermaphroditic individuals and catkins (containing male and female flowers) have been observed in some species (Alliende and Harper 1989, Crawford and Balfour 1983, Mosseler and Zsuffa 1989, Zasada et al. 2004). The sex ratio between plants is often female biased, with ratios as high as 4:1 (Alliende and Harper 1989, Crawford and Balfour 1983, Fox 1992, Kaul and Kaul 1994, Kay and Chadde 1992, Zasada et al. 2004).

Many species can flower at a very early age; however, more flowers are produced as the plant ages. Seedlings have been observed flowering one year after germination, and plants originating from cuttings can flower the same year (Zasada et al. 2004). Coyote willow flowers when stems are 2-3 yrs old, but flowering increases significantly (93\%) when stems reach 9 yrs of age (Ottenbreit and Staniforth 1992). Seeds are small, 1-2 mm long, khaki green to dark green, with a long tuft of feathery cotton attached to the seed that aids in wind and water dispersal. Willows can be classified into two general categories: summer dispersers (most species) and fall dispersers (arctic, tundra, alpine and some boreal species). Capsules typically ripen one month after flowering. Good seed crops generally occur every year.

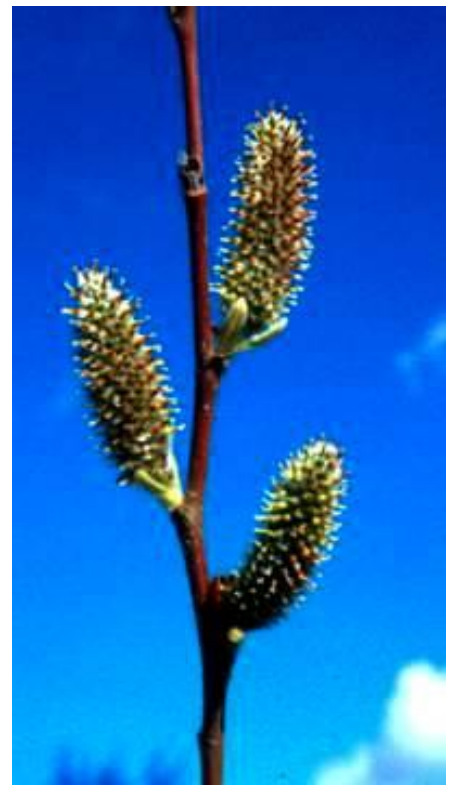

Figure 7.8a. Willow catkin, female (Photo T. Luna)

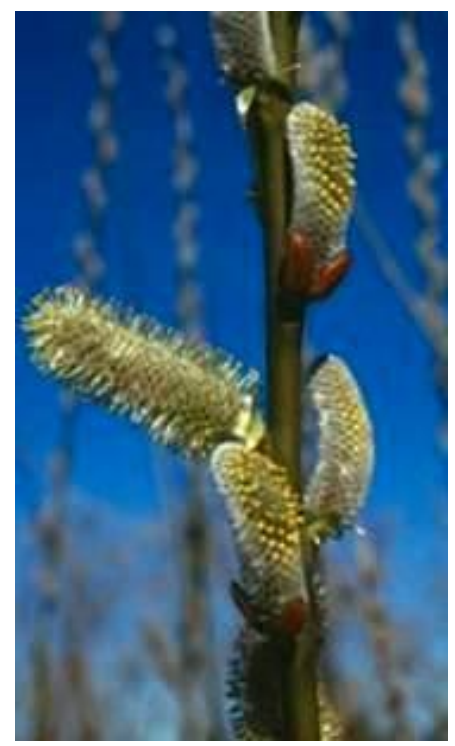

Figure 7.8b. Willow catkin, male (Photo T. Luna)

The fruits in both genera are small capsules bearing numerous seeds, each of which has a small tuft of hair that aids in dispersal. Many species shed the entire catkin at seed maturation, sometimes forming a carpet of cotton under trees in late 
spring and summer. The seeds contain very scant or no endosperm, which serves as a food reserve for the embryo. Most species have no seed dormancy and seeds are considered to be very short-lived under natural conditions. Because of their small size, rapid dispersal, and short longevity, seed collection must be carefully timed. Marking known female trees prior to collection will make seed monitoring and collection easier.

\section{Identifying Willows and Cottonwoods: A Crucial Step in the Revegetation Process}

Throughout Montana, there are many native species of cottonwoods and willows. Both genera can be difficult to identify to species. This is further complicated by the fact that in some areas of Montana, especially near farms, ranches and towns, non-native cottonwoods and willows have been planted as windbreaks or for ornamental purposes. Some of these species have escaped cultivation and occupy natural riparian or wetland communities. European white willow (Salix alba) and crack willow (Salix fragilis) have been extensively planted for ornamental purposes and can easily be mistaken for a native willow in a natural riparian area, especially during the winter dormant period. Other non-native willows include hybrid crack willow (Salix $x$ rubens) and laurel willow (Salix pentandra). Hybrid cottonwoods such as white poplar (Populus alba), hybrid balsam poplar (Populus brayshawii) and columnar, hybrid forms of eastern cottonwood (Populus deltoides X Populus nigra) "Lombardy Poplar" have been extensively planted in this region of Montana. Some of these species, such as white poplar and crack willow, are considered invasive species in other regions of the United States. Thus, it is crucially important to correctly identify that the willow or cottonwood species in question is native before any material is collected for propagation and restoration purposes.

Willow is a large, complex, and highly variable genus. Taxonomic features such as the flowers, fruits and leaves are useful for keying but are not usually available at the same time. This is especially true of the catkins, usually present for only a few weeks in the spring or summer months. Differences between species are often very subtle, and variation within a given species can be quite large. This is further complicated by collection of material used for species identification; vigorous young suckers or shoots can have abnormally large leaves and stipules, resulting in misidentification. In some cases, leaves can exhibit great variation in size and morphological characters (such as the presence or absence of toothed margins) even on the same individual. Variation in taxonomic characters is easily seen in different ecotypes. It is widely believed by both botanists and horticulturists that natural hybrids are common, and hybrids can be found between species. However, it is essential that both the nursery grower and restoration biologists be able to differentiate between Salix species correctly and determine the sex within a species of this important group of plants, whether the restoration material is cuttings or seedlings.

For proper identification, keying should be done on fresh material in the field using a hand lens with at least 10X magnification. Mature male and female catkins and leaves should be collected from several separate plants. Material should be keyed on both flower and vegetative characters. Flower characteristics are generally more reliable than vegetative characters. Sucker shoots or diseased or insect infested material should be avoided. The population should be inspected and further variability noted while keying. Use a local flora and check your result with at least one other flora if possible. Be sure to obtain vegetative branches and note for the presence or absence of stipules. Other important characters in keying species include the number of stamens, bud scales, the color and size of floral bracts, whether they are deciduous or persistent in fruit, and the presence or absence of glands at the base of the leaf blade. It is also 
important to note the elevation, habitat, and hydrology of the area, and to cross reference the elevation range and habitat preference for that species. Care in species identification will ensure the correct species is being propagated for the appropriate habitat and is ultimately planted in the right hydrological zone of the restoration site. Concurrently, you will be able to locate and mark female trees for future seed collection efforts.

\section{Identifying Male and Female Trees}

Many collectors utilize cuttings collected during fall or winter months before flowers and leaves emerge. Identifying unknown willows at this stage is much more difficult (if not impossible) for some species. However, it is possible to determine sex between individuals at this stage using floral buds. When collecting dormant cuttings, the collector will need a 10X hand lens, sharp razor blades, and a needle to dissect the floral buds.

Leaf buds can be distinguished from floral buds in both genera. Leaf buds are generally more pointed in shape. Floral buds are distinguished as always being subterminal on the branch and generally rounder in shape. In both cottonwood and willow, male buds are generally larger than female buds during the winter months as they are the first to emerge in the spring. The floral bud can be dissected using a razor blade. Anther sacs and compressed filaments can be seen in between the green floral bracts under magnification in male buds. Female buds are smaller than male buds during the late fall and early winter months. They become more developed and larger later in the spring. In cross section, female buds will have small, round to flask shaped pistils in between the leafy bracts. After several field inspections, the collector may develop a visual cue for the different sexes during winter months based solely on the size of the floral buds. This is especially true for cottonwood, which has much larger buds, but is much more difficult for willows. By examining the floral buds, collectors can ensure that both sexes are being planted onto the restoration site when using dormant cuttings, pole plantings, and bioengineering materials.

In the past, it was common to randomly collect hardwood cuttings to be used for various bioengineering materials (poles, branched cuttings for fascines or bundles) without noting that collections may consist of only one sex. This could potentially have long-term implications, especially if the riparian or wetland site is isolated, or the remaining stand is failing to reproduce by seeds. Because natural seedling recruitment over the long term is desired, collectors must take extra efforts to collect cuttings of both sexes.

\section{Collecting Other Vegetative Propagules for Restoration Purposes}

In some cases and for some species, seeds may not be available for collection. Vegetatively propagated material may be desirable in species with seeds that are difficult to collect and/or dispersal mechanisms that limit feasible seed collection. The planner must consider if collecting other forms of vegetative propagules is desirable and within the constraints of budget and available labor. Many wetland species exhibit asexual reproduction through various forms of vegetative structures including rhizomes, stolons, tubers, shoot fragments, and vegetative buds. Emergent and submergent wetland species that reproduce vegetatively by rhizomes include many species of sedges, rushes, spike rushes, bulrushes, grasses, and some broadleaf emergent and submergent forbs. Typically, plants produced by divisions are more costly than seed propagated plants because it requires obtaining and maintaining donor plants, and divisions usually require more labor and larger containers which add significantly to costs per plant. However, if the restoration plan is to restore existing populations of a targeted speciesand/or genotype and no seeds are available, this may be the only option available. 
Rhizomatous species can be propagated easily into larger numbers of plants by divisions from a few donor plants (Figure 7.9). Some species reproduce by stolons, most notably silverweed (Argentina anserina), alkali buttercup (Ranunculus cymbalaria), and wild strawberry (Fragaria virginiana), and the resulting plantlets can be used a source of vegetative propagules for restoration (Figure7.10). Depending on the species, one stoloniferous or rhizomatous plant has the potential to cover several meters of the soil surface over time. Tubers are a modified storage organ seen in arrowhead (Sagittaria) species; they can be used as a source for propagating plants when seeds are unavailable.

Submergents that reproduce asexually through shoot fragmentation possess a high degree of regeneration, with many plants produced from a single donor plant. Shoot fragmentation occurs naturally by disturbance or senescence and can disperse throughout the open body of water; shoot fragments can be dispersed more widely by birds (Figure 7.11). Some examples include water starwort (Callitriche species), Canadian waterweed (Elodea canadensis), water milfoil (Myriophyllum species), mare's tail (Hippuris vulgaris), white water buttercup (Ranuculus aquatilis), burreed (Sparganium species), and some pondweeds (Potamogeton species). Many of these species exhibit different rates of establishment following fragmentation (Barrat-Segretain et al. 1998).

Many northern temperate submergent species produce modified vegetative buds that consist of tightly compressed leaves at the end of stems (Figure 7.12). Modified buds, also known as turions, develop towards the end of the growing season in response to shortening day lengths; they drop and disperse from the parent plant in early fall. Turions can float or sink, and can be widely dispersed by migrating waterfowl. Turions can remain dormant through the winter months; growth is triggered by increasing day length, warmer water temperatures and increasing nutrient availability, similar to dormant seeds. Species that form turions include common hornwort (Ceratophyllum demersum), bladderwort (Utricularia species), water milfoil (Myriophyllum species), and Canadian waterweed (Elodea canadensis). Turions can be collected and introduced into the open water edges of the wetland restoration site immediately after collection (Hoag 2010). However, in the case of water milfoil species, collectors must be absolutely certain of positive identification to species to prevent the spread of the introduced, invasive European water milfoil (Myriophyllum spicatum). Similarly, many other exotic species spread by vegetative organs such as curly pondweed (Potamogeton crispus).

\section{Summary}

The decision to undertake intensive revegetation requires careful planning, and the process begins with the selection of appropriate, site-adapted plant sources. Selection of seed source and donor plants is one of the most crucial decisions that can ultimately affect the survival and establishment of the restored species or plant communities.

Restoration planners must allocate the budget, time, and resources needed to obtain adequate quantities and quality of genetically adapted seeds and cuttings, in order to meet the goal of reestablishing self-sustaining plant populations. Wetland and riparian species exhibit unique characteristics in their reproductive strategies, morphology, and ecology. Thus, the planner and collectors must be familiar with the biology and ecology of each species in order to properly identify and collect quality material. The wide diversity of taxonomically challenging species in wetland and riparian areas means that collectors must have the ability to correctly identify the species. This is especially important because there are many invasive non-native species that are taxonomically and morphologically similar. Collectors must know the species in the source community. Seeds, cuttings, and other vegetative propagules are living 
are living entities and must be collected and handled with special considerations and precautions appropriate to the species.

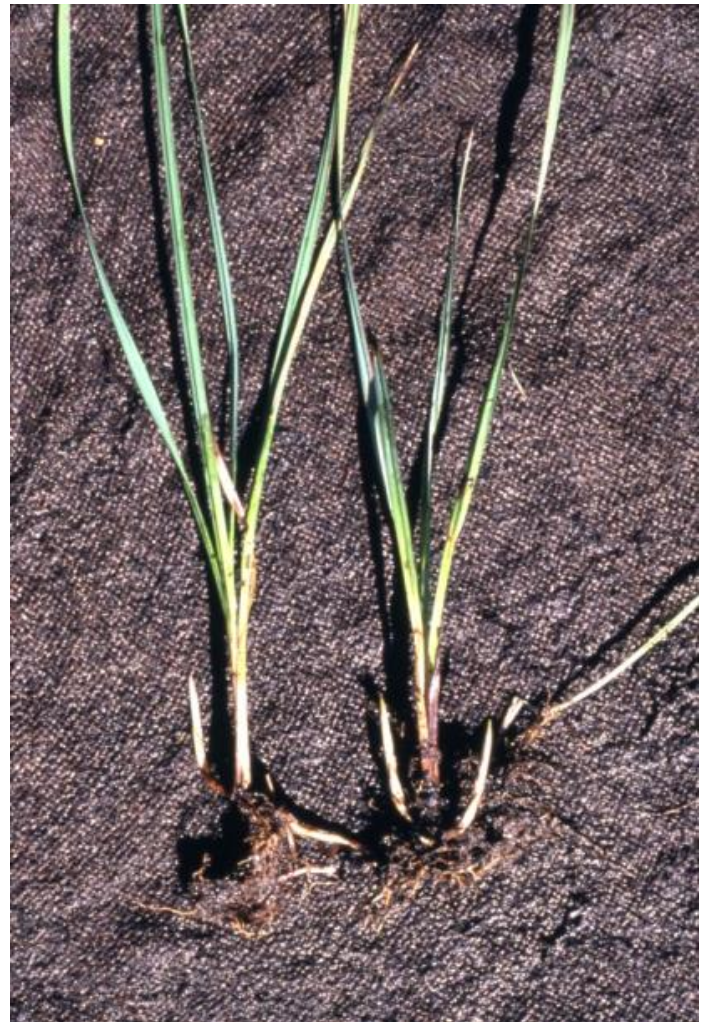

Figure 7.9. Rhizome divisions (Photo courtesy T. Landis)



Figure 7.10. Stolons Argentina anserine (Photo T. Luna)

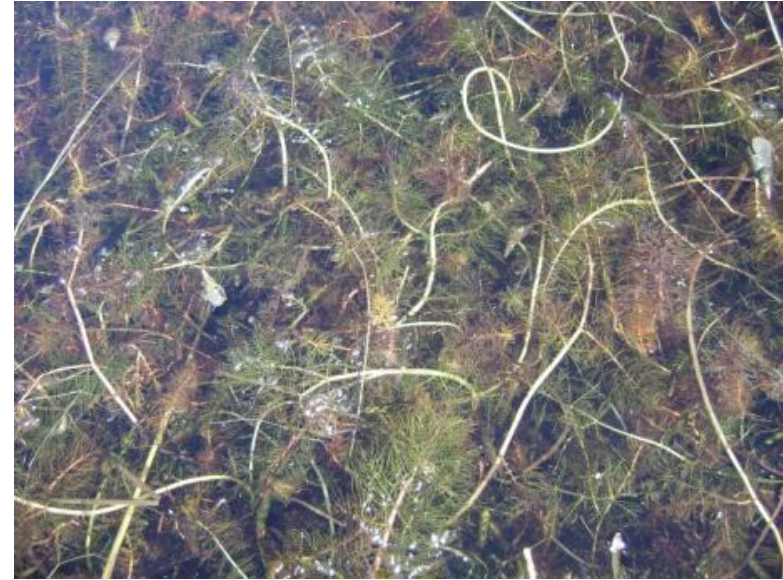

Figure 7.11. Shoot fragments, submergents (Photo T. Luna)

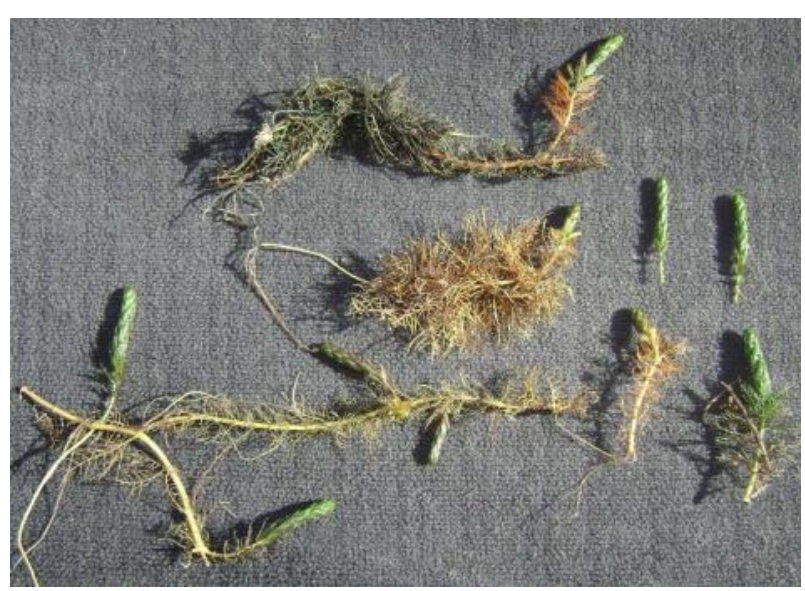

Figure 7.12. Turions (Photo T. Luna) 


\section{Chapter 8: Stock Selection and Site Planting}

Nursery stock types must be appropriate for the project site. Selection of stock types will depend on the species and any environmental conditions that may affect or limit establishment and survival. Nursery stock should be grown in a way that conditions the stock physiologically to tolerate conditions of the restoration site. Thus, production of nursery stock must be scheduled to coincide with the narrow windows of planting opportunity, during periods of available water. Handling of nursery stock during transport and temporary storage, availability of trained labor, and the quality of planting can affect the success of the plantings. Success of plant establishment may require that different stock types (seedlings, seeds, or cuttings) are planted at different optimum times. Timing and methods used in revegetation can have a profound effect on the establishment of native vegetation.

\section{The Outplanting Window in Wetland and Riparian Restoration Sites}

Unlike upland restoration plantings, the outplanting window for riparian and wetland plantings is more narrowly confined. Planting cannot occur during flooding or high water events in riparian areas or during periods of full inundation in some zones within herbaceous wetlands. However, planting must occur when water is still available for a long enough period of time to support plant establishment, growth, and accumulation of enough root mass and food reserves to survive periods of water unavailability and winter conditions. Nursery stock must become fully established before full drawdown during late summer and fall months, so that roots can grow beyond the nursery root plug into the soil and access deeper soil moisture. The full establishment of additional roots and rhizomes in the soil profile will also prevent frost-heaving of the root plug during winter months. Thus, nursery stock must be planted when there is available soil moisture. High survival rates are crucial because nursery stock provides structural support to the restored plant community and creates microenvironments that support the recruitment and establishment of the understory community.

In northern Montana, water availability changes rapidly over the growing season. Full inundation and high water events occur mostly in May and early June. Thus, for many herbaceous dominated wetlands such as potholes, depressions, and marshes, the outplanting window is confined to early to late June, just after full inundation but when there is standing water of at least 1-2 inches. Similarly, the outplanting window for riparian or floodplain areas is limited to late June, after spring runoff but when soils are moist and the water table and capillary fringe are present to support plant growth and establishment .

\section{Planning and Scheduling the Nursery Stock for Outplanting Windows}

With such a narrow window of planting opportunity, the planner must ensure that all nursery stock is fully grown, conditioned, and delivered on a specific date. Any other restoration activity such as land contouring, restoring hydrology, and other activities to augment and support the survival of the plantings must occur well in advance of the actual planting or seeding window.

The planner must make decisions regarding what target stock type and stock type size is required for the site conditions. For example, nursery grown sedge seedlings are a better choice than seeds on disturbed wetland sites, because seedlings can compete for resources with invasive species (Budelsky and Galatowitsch 2004). Several stock types are available: container grown seedlings, 
and rooted cuttings, bareroot seedlings, non-rooted cuttings, and seeds. Container grown seedlings and rooted cuttings are the most common stock $\mathrm{t}$ ype used for most wetland and riparian species. Stock type size for container grown plants is usually expressed by container volume (the volume of the root plug), and the height and diameter of the container. The volume of a container dictates how large a plant can be grown in it. Container height is important because it determines the depth of the root plug, which is an important consideration in wetland and riparian restoration projects. Choosing container stock types with deep root systems is desirable so that roots can stay in contact with soil moisture throughout the growing season.

High outplanting survival is usually achieved with container plants that have a firm root plug. The root system forms a firm plug with healthy roots that bind the nursery growing medium just enough to facilitate extraction from the container without the medium falling off the roots. However, plants grown in containers that are held too long in the nursery can decrease in their physiological quality and ability to survive on the restoration site. The container in which the plant is being grown is a confined space, and roots can become deformed (or lignified in woody species) with the amount of time that plants are kept in a container. As the roots become bound or the amount of feeder roots decreases, outplanting survival in the field decreases. Thus, to ensure quality stock, the restoration planner and nursery manager must correctly time nursery stock to be ready for the outplanting window date. Holding stock over in he nursery can decrease plant root quality and decrease survivability on the restoration site.

The time needed to grow a particular species varies greatly depending on the stock type selected, its ease of propagation, and its rate of growth under nursery conditions. Time must also be scheduled to harden or condition the nursery stock before outplanting. Generally, the larger the stock type, the longer it takes to produce the plant. For example, production time for unrooted cuttings is usually only 2-4 months. Cuttings are collected in late winter or early spring when stems are dormant; they are held in cooler storage before they are installed during a late spring outplanting window. For container grown stock types, the time to produce a seedling or rooted cutting varies widely, depending on the species and the size of the container. For fast growing herbaceous species, the time to produce can be 4-6 months, whereas woody seedlings require up to one year prior to planting. The timeline and process of obtaining nursery stock types - from collection of propagules to growing and transporting the plants back to the restoration site - will vary and requires careful planning around a specific outplanting date.

The use of seeds in wetland and riparian restoration projects is largely limited to grasses and forbs occurring in transitional zones between the wetland and upland community, riparian understory communities, slopes along rivers and streams, and adjacent upland buffer zones. If locally adapted seed sources are not commercially available, the planner will need to obtain an initial seed collection that will be grown for the production of seeds. This usually requires a timeline of 2-3 years prior to the seeding window. Ultimately, the planner must use forecasted precipitation cycles to target revegetation efforts.

\section{Stock Types for Herbaceous Species}

The most common stock types for herbaceous species are container plugs (plants grown in containers) or seeds (used for direct seeding). Obligate wetland sedges, rushes, bulrushes. and spike rushes have very small seeds and very specific germination requirements. These species are usually grown and planted as seedling plugs instead of being directly seeded onto the restoration site. The most common container stock type sizes for herbaceous species are usually small, ranging from 4-20 cubic inches. Using a larger plug size 
size (20 cu-inch), however, will ensure that more rhizomes will spread, sprout, and establish from the root plug during the first growing season and ensure that the plugs will survive during drawdown in late summer (Figure 8.1). Generally, using larger container seedlings with larger root volumes enhances survival rates; it also shortens the time to achieving higher canopy cover and root spread on the restoration site.

Seeds can be obtained from commercial seed producers if locally adapted genetic sources are available, or they can be obtained from site-specific locations and sent to a seed producer for increase. If time, labor and sources are available, seeds can be bulk collected from naturally occurring populations. In some cases, seeds may be used as a stock type for minor species in the plant community that may fail to disperse into the site, or when there may be limitations on recruitment from the seed bank.



Figure 8.1 . 20 cubic inch sedge plug (Photo courtesy C. Hoag)

\section{Stock Types for Woody Species}

Nursery stock types for woody species vary considerably and can be in the form of rooted or unrooted cuttings or seedling grown plugs. Unrooted cuttings can be a variety of lengths and diameters, depending on how they will be used. Dormant cuttings are collected in late winter to early spring, and are stored in cold storage to keep them fully dormant until they are planted. Live stakes are usually 12-16 inches $(30-40 \mathrm{~cm})$ long; fascines or branched cuttings are usually 2-6 feet (0.6-1.8 meters) long. Live stakes and branched cuttings need to be long enough to reach moisture in the soil profile; they are usually driven into the ground with a mallet with only 3-4 nodes (buds) above ground. Pole cuttings are much longer, usually 12-16 feet (3.6-4.9 meters) long, and are driven deep enough in the soil profile to reach moisture, particularly deep enough to reach the capillary fringe just above the water table during the driest part of the growing season. The above ground portion of the stem is much longer, usually above browse line.

Rooted cuttings are collected from the project site or from mother plants maintained at a nursery, and are rooted and grown in containers. Container stock type size for rooted cuttings varies greatly. Smaller containers are usually 10 or $20 \mathrm{cu}$. inches, and these sizes can be used for woody species if site conditions are suitable. However, cuttings of cottonwood and some willow species can be grown in deep containers that are up to 30 inches tall (Figure 8.2). These larger stock type sizes have exhibited exceptionally high survival rates in riparian restoration projects, especially in the desert Southwest, where prolonged drought events, infrequent flooding regimes, irrigation, and other alterations to the hydrology have resulted in 
in a deeper water table for longer periods during the year (Dreesen et al. 2002, Dreesen and Fenchel 2008)

Another advantage of these deep container sizes is that they produce trees or shrubs that may be able to better withstand periodic flooding events following establishment, compared to smaller container rooted cuttings or seedlings. Larger containers occupy more growing space, and take longer to produce a firm root plug. Therefore, plants in larger containers are more expensive to produce; they are also more expensive to store and ship to the project site, and may require special tools and more labor to plant. The benefits of high survival, however, may outweigh the higher costs if the restoration objectives are more successfully achieved.

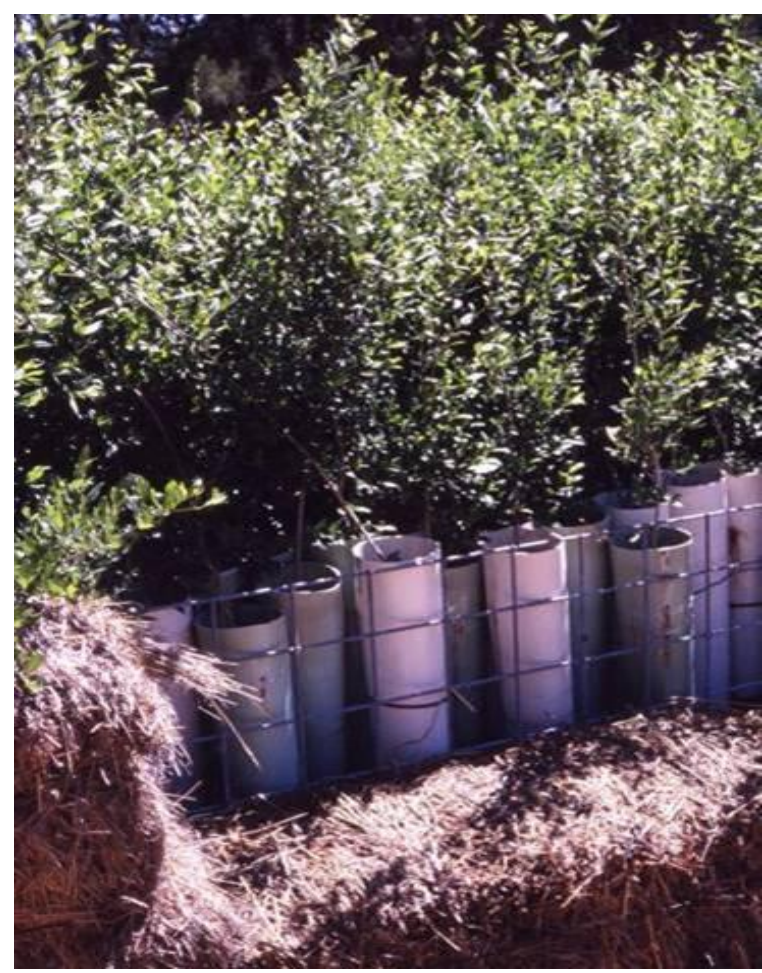

Figure 8.2. Deeper tree pots for willow (Photo T. Luna)

\section{Physiologically Hardened and Conditioned Nursery Stock}

Nursery stock should be grown under conditions that ensure it is physiologically conditioned to withstand the environmental conditions of the restoration site. Without hardening and conditioning, nursery stock may perform poorly or die after outplanting. The planner must work with the nursery to gain an agreement on how the stock will be grown under conditions that will ensure that the plants are hardened and conditioned prior to outplanting.

The nursery or greenhouse environment differs radically from that of the restoration site. Ample supplies of nutrients and water are supplied during growth, usually in a wind-free environment. Under these conditions, plants develop tissues that have not been subjected to the normal stresses of a natural environment and thus require certain conditions to promote tissue hardening and development prior to outplanting. This creates nursery stock with hardened stem tissues, healthy dormant leaf buds, and sufficient carbohydrate reserves to promote vigorous growth the following spring.

Hardening is the process of gradually inducing hardiness to plants toward the end of nursery culture to increase durability or resistance to environmental stresses on the restoration site. This is a critical requirement for promoting outplanting survivability because on most restoration sites, no after care is provided to ensure plant survival, so plants must be in the best physiological condition possible. Using knowledge of the expected conditions of a given restoration site, nursery cultivation can be adjusted to acclimatize seedlings for site conditions by promoting physiological hardiness.

For woody plants, many restoration planners use stock that is fully dormant during outplanting. 
This has several advantages. Water loss by transpiration is minimized. This condition allows the plants to break bud after planting, so that the plant can conserve its resources for root development during the initial week or so after outplanting. It also allows outplanted deciduous stock to develop leaf tissues after budbreak in response to the environmental conditions of the restoration site. Nurseries with adequate cooler and freezer storage systems can keep fully grown stock in dormancy from fall to early summer. However, there is a limit on how long nursery stock can be held under these conditions.

Wetland herbaceous species such as sedges, rushes, spike rushes, and bulrushes can be germinated and grown in a nursery environment just like upland species as long as sufficient amounts of nutrients and water are supplied. However, all of these wetland species must develop aerenchymous tissues that allow them to withstand flooding and anaerobic conditions. In order for stock to be properly conditioned and "hardened" prior to planting, the stock must be grown under conditions that support the full development of these tissues in the leaves, stems, and roots. This allows seedlings to acquire greater physiological tolerance to anoxic conditions. Most wetland nursery suppliers grow these species in artificial pools and troughs filled with water, where they can control flooding and drawdown cycles to condition the stock to the same hydrological regimes that exist in the wetland. The restoration planner should tour the nursery facility and discuss these requirements before growing contracts are developed.

\section{Transport, Care and Temporary Storage of Nursery Stock during Outplanting}

Nursery stock requires special care during transport and temporary storage at the restoration site. Once seedlings or cuttings have left cooler storage, they should not be allowed to dry out or be subjected to high or freezing temperatures. Care is needed to minimize stress and water loss from the tissues and roots until all seedlings or cuttings are planted. Transporting boxed or wrapped seedlings in the back of an open truck is acceptable only if air temperatures in these locations are less than $7^{\circ} \mathrm{C}$ $\left(45^{\circ} \mathrm{F}\right)$, or as much as $18^{\circ} \mathrm{C}\left(60^{\circ} \mathrm{F}\right)$ for short distances. Special tarps are available that reflect sunlight and insulate nursery plants during transport. Non-reflective tarps should never be placed directly on the seedling boxes. This can actually increase the temperature more than if the sun shines directly on them. If plants have to be carried long distances to the planting site, some nurseries can "jelly-roll" the plants to protect the roots from desiccation. The process consists of aligning the plants with the roots folded in a wet cloth, rolling them into a bundle, and securing the bundle. Thus, specifications can be made on how nursery stock is prepared, stored, and transported in nursery contract agreements.

In general, dormant seedlings and unrooted cuttings must be placed in the ground within approximately 72 hours after leaving cold storage. During outplanting, seedlings and cuttings must be stored in a temporary cache adjacent to the planting area, protected from sun and wind. Boxed seedlings and rooted cuttings must be kept in the shade at all times. One of the planters must be responsible for the care of the seedlings until all of them have been planted. Watering may be required if nursery stock begins to dry out during temporary storage. Unrooted cuttings can be stored in water to hydrate them before installation (Figure 8.3). Only the number of seedlings or cuttings that can feasibly be planted in one day should be distributed from the temporary cache. Environmental conditions at field planting time can have a major impact on seedling and cutting viability and survivability after planting.

Planting conditions are best on cool or cloudy days. When possible, schedule planting on days when the weather forecast favors survival. If at 


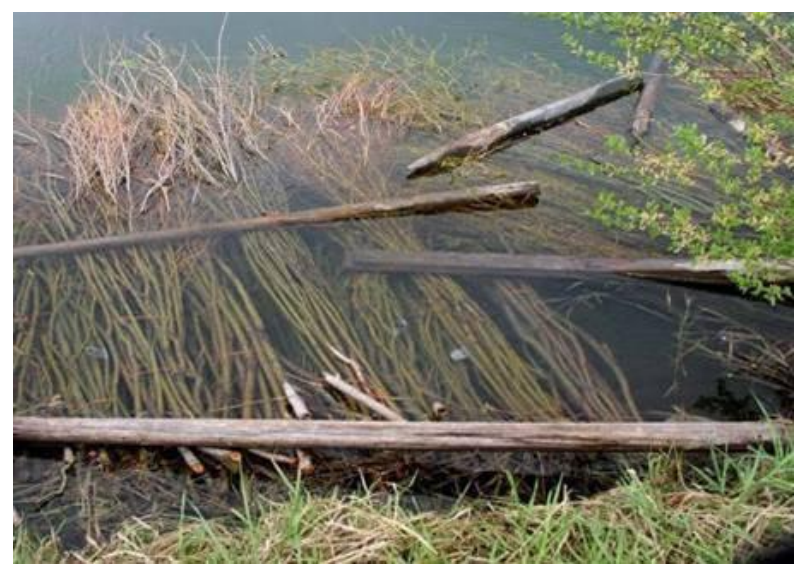

Figure 8.3. Cuttings stored in water (Photo courtesy C. Hoag)

(Figure 8.5). Cottonwoods (Populus species) and willows (Salix species) also occur in distinct zones along a water availability gradient in riparian areas. The specificity of each species illustrates the importance of delineating planting areas into specific hydrologic zones all possible, do not plant on hot, dry, windy days. In some cases, the nursery or planting crew may need to trim the shoots of herbaceous stock prior to site delivery or planting to lower transpirational water loss. Removal of one -third of the herbaceous shoots may contribute to overall higher survival, especially with herbaceous species that are planted in the drawdown zones. Woody nursery stock is usually stored in freezers or coolers at the nursery and is usually fully dormant during outplanting.

\section{Planting Densities and Patterns}

In the previous chapters, we have seen how hydrology, soil properties, water depth, and water and soil chemistry affect the limitations of species establishment and form plant association boundaries within the wetland. Water depth tolerance determines distribution of emergent wetland species within the wetland. Therefore, to approximate a natural vegetation community, careful consideration must be given to planting patterns. Prior to planting, the hydrology zones and variations in soil types, organic matter accumulation, and plant associations will have been mapped. These variations in site conditions define where species will grow or regenerate within the restoration site, and they delineate the planting areas for revegetation.

All species must be planted in the correct hydrologic zone of the restoration site. Rushes (Juncus species), sedges (Carex species) bulrushes (Schoenoplectus species) and spikerushes (Eleocharis species) are the most common herbaceous species occurring in depressional wetlands. They are frequently used in newly created wetland mitigation sites. Despite their common occurrence in wet soils, rushes and some sedge species are generally not tolerant of prolonged periods of anoxia and thus must be planted in the outer drawdown perimeter of the wetland. Bulrushes, other sedge species, and spikerushes are adapted to longer periods of anoxic conditions, exhibit a wider range of tolerance, and therefore occur in zones that hold water for longer periods. Thus, communities occur in concentric peripheral bands along a drawdown gradient, based on their adaptation to different periods of flooding. (Figure 8.4). Cottonwoods (Populus species) and willows (Salix species) also occur in distinct zones along a water availability gradient in riparian areas.



Figure 8.4. Plant zones along drawdown (Photo T. Luna) 
The specificity of each species illustrates the importance of delineating planting areas into specific hydrologic zones

Minor species in particular will need to be planted in suitable microsites. Again, notes on patch types and microsite characteristics can be used in the development of planting patterns. Plants can be placed in clusters to mimic natural dominant communities; this may contribute to overall higher survival rates. The development of a planting pattern that approximates a natural community is dependent on all of these factors.

Planting densities and spacing are determined by species density (or cover) at reference sites, site conditions, predicted rate of spread or crown maturity, and the amount of cover desired for both long- and short-term objectives. It is also important to factor in mortality rates for each species, because unless all conditions are ideal, not all the planted stock will survive. Generally, the higher the planting density, the sooner the planting area will fill in with vegetation. A higher planting density may be desirable if one of the objectives is to limit the establishment of non-native vegetation or to provide wildlife cover and forage in a shorter time frame. The ratio of species per planting area must also be determined based on the species composition of reference plant associations. Generally, species tend to occur to together in clusters or clumps. Paying attention to patch types of species at reference sites will help the restoration planner develop a planting pattern and species ratio that will approximate the reference community to the greatest extent possible.

For many wetland emergent species with vigorous rhizomatous root systems such as sedges, rushes, spike rushes, bulrushes, and grasses, plants can be planted on an 18 inch spacing, with individual plants spreading up to 12 inches per year. In wetland restoration projects within Idaho, seedlings planted at wider spacing had an overall lower survival rate than those planted at higher density
(Hoag 2010). These results indicate that closer planting densities may enhance overall survival of the entire planting. Higher planting densities may create a "nurse plant effect" by providing structure that reduces overall physiological stresses on individual seedlings.

Another important consideration during outplanting is the selection of microsites within the planting area. On steep, wooded riparian streambank slopes, placing plants in microsites ensures higher survivability. Planting in protected microsites provides some shade during part of the day, cooler temperatures, additional soil moisture, and protection from wildlife and livestock browsing. Intense sunlight on barren slopes can kill woody stems at soil line, and full sun exposure can create additional moisture stress. Planting in suitable microsites that favor plant growth is even more important than plant spacing.

\section{Planting Crews and Post Planting Care}

The quality of the actual planting is the final factor in ensuring high outplanting survival. The proper tools for each stock type, ones that facilitate ease of planting, must be selected and obtained in advance. The right tool can affect plant survivability and ultimately reduce labor costs. Some common hand planting tools include dibbles, bars, hoedads, and customized shovels with a spade long enough to plant larger containers. All types are available in varying sizes. For wetland herbaceous nursery stock, dibbles, bars, and hoedads are commonly used. For woody nursery stock, hoedads and custom shovels are usually the tool of choice. Planting tubes are mechanized dibbles that create a planting hole. They are available in a variety of tube diameters. Some models have the capacity to adjust the planting depth. Motorized augers are useful on deeper soils with little rock content. They are used for larger, deep container stock and pole cuttings. There are one- or two-person models available. Augers require frequent maintenance and 
should be tested first on the project site before the actual planting. They can be very useful and efficient tools in large revegetation projects.

Planting crews must be able to plant the container stock in such a manner that the root plug is at the proper depth, with the shoot or stem crown flush with the soil line. The planting hole must be made deep enough that the root plug can be completely covered with native soil. The top of the root plug must also be covered with native soil, and the entire root plug must have good root-to-soil contact after the plant is placed in the hole. Equally important, the root plug must be planted vertically within the soil profile. This prevents "J-rooting" and detrimental exposure of the root plug. The plug must not be planted too deep. However, in riparian restoration projects, deep container woody plants and pole cuttings are planted deep enough to reach the capillary fringe above the water table (Figure 8.5).

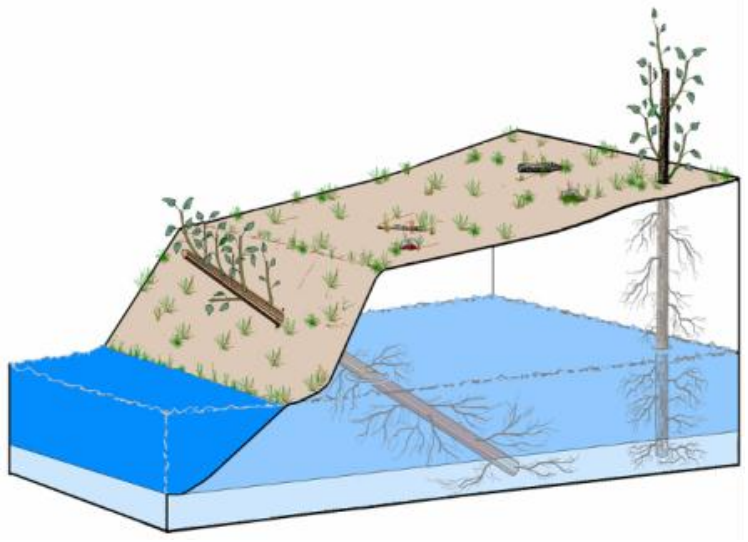

Figure 8.5 Proper planting of pole cuttings (Illusttation courtesy T. Landis)

After planting, the holes must be backfilled with native soil free of rocks or woody sticks. The soil must be firmly tamped around the plant after planting to remove air pockets. This is crucial when planting in standing water in order to secure the plants to the soil. Excessive tamping or stomping can compact the soil and injure roots and stems.
Foliage and buds should not be buried, except in the case of dormant pole cuttings, which are planted with leaf buds buried with up to two-thirds of the stem below soil line. Roots will form along the stem after planting. It is important to emphasize that improperly planted nursery stock either dies or fails to grow and spread vigorously, often for years after installation.

South and southwestern aspects are hotter and drier than north and east facing aspects in all areas except flat terrain. These aspects must be planted first to maximize the length of time that soils remain moist. Similarly, in herbaceous dominated depressional wetlands, the outermost drawdown zone must be planted first to maximize the amount of time of available soil moisture. The root plug must be moist when it is unpacked, when removed from the temporary cache, and during planting. If any nursery stock dries out during the day, a quick water dip is usually sufficient to protect the roots from desiccation.

Correct planting depth is critical in the establishment of nursery stock, as is the first growing season following outplanting, because root systems must become well established beyond the root plug into the surrounding soil. This anchors the plant to saturated soils and prevents "washout." It is also important so that container grown nursery stock does not "frost heave" out of the planting hole during freeze-thaw cycles during late winter and early spring. Greater potential for frost heaving occurs on clay and silt soils. South and southwestern aspects or exposed sites have more of a problem with frost heaving because high solar exposure intensifies the freeze-thaw cycle (Landis 2010).

Depending on the quantity and stock types used, the planner must factor in enough labor to complete the full planting within the narrow outplanting window. Depending on the size of the project, at least 1-3 experienced planters should be present to train and supervise the installation of the plants. 
This is especially true on restoration projects where there is a voluntary or inexperienced work force. Training on proper planting techniques and quality assurance is needed during outplanting. Planting crew leaders must visually inspect and closely supervise the installation of the plants. When there is a large voluntary work force, experienced planters can properly dig the holes, while volunteers plant the seedlings. This allows crew leaders to select microsites and ensure that planting holes are correctly made and backfilled.

In riparian areas, woody stock can be protected from browsing by caging cuttings or seedlings, especially those stock types that tend to be smaller. Seedlings are caged in areas where heavy browsing is anticipated. In some plantings, shade cards may be needed to protect seedlings during the first few years of establishment.

\section{Plant Salvage}

Plant salvage is mostly limited to sites where existing native vegetation will be obliterated by other restoration or construction activities. Appropriate seed bed preparation ensures optimal soil structure that allows for numerous safe sites, while being firm and loose enough to allow good seed to soil contact during germination and establishment. Seed bed preparation will vary among sites and soils, accessibility, erosion potential, weed invasion potential, seeding method used, and composition of the seed mix.

In upland buffer restoration plantings, sites with compacted soils are usually scarified by harrowing, chiseling or dragging small chains that break apart topsoil aggregates. Plowing is not recommended on fine textured soils or where there is existing native vegetation. Compacted upland soils will require adequate seed bed preparation. Seedbed preparation is recommended when using broadcast seeding or hay-mulch seeding methods. If the upland buffer has been recently burned, the residual ash layer provides an excellent seed bed when using either of these seeding methods.

Salvaged plants are then transplanted to a suitable location without existing vegetation within the restoration site. In Montana, native graminoid dominated turf is frequently salvaged during stream channel realignments. Salvage is performed with heavy equipment and requires special precautions to minimize damage to wetland soils. Typically, salvage operations are performed during spring months when plants are fully dormant. During woody plant salvage, the equipment operator must lift a large root mass to increase the likelihood of survival. Herbaceous plants are lifted similarly to turf mats and transported to the new site for installation. Salvaging may be especially desirable when a particular species of interest has little possibility of surviving long term on the donor site. In any case, the donor site should be inspected for non-native species before selecting plants for salvage and planting into another wetland. Seed bank tests of the donor site will ensure that new weeds are not introduced into the restoration site.

\section{Direct Seeding}

Similar to nursery stock plantings, project sites that are directly seeded must be prepared in advance to facilitate ease of germination and establishment. Providing micro-topographic heterogeneity, or safe sites for seed germination, improves the ability of seeds to germinate and establish, and may also contribute to improving natural recruitment and colonization of other species over time. Roughened soil conditions that provide numerous safe sites or germination niches may increase native grass seed germination and establishment, and may also decrease the recruitment and competitive ability of non-native grasses onto the restoration site. This type of site preparation for direct seeding is limited, however, to transitional zones between wetlands and uplands, upland buffer plantings, slopes adjacent to streambanks, or in some cases, the 
, the understory in riparian areas.

Appropriate seed bed preparation ensures optimal soil structure that allows for numerous safe sites, while being firm and loose enough to allow good seed to soil contact during germination and establishment. Seed bed preparation will vary among sites and soils, accessibility, erosion potential, weed invasion potential, seeding method used, and composition of the seed mix.

In upland buffer restoration plantings, sites with compacted soils are usually scarified by harrowing, chiseling or dragging small chains that break apart topsoil aggregates. Plowing is not recommended on fine textured soils or where there is existing native vegetation. Compacted upland soils will require adequate seed bed preparation. Seedbed preparation is recommended when using broadcast seeding or hay-mulch seeding methods. If the upland buffer has been recently burned, the residual ash layer provides an excellent seed bed when using either of these seeding methods.

How a restoration area is reseeded is determined by several factors: how seeds are distributed, the germination requirements of each species in the seeding mix, the optimal seeding window, and seed placement on or within the soil. Species vary widely in their requirements for germination. Most grass and transitional meadow forbs require some burial for germination, while the vast majority of annual species and perennial sedges, rushes, and bulrushes occurring in the drawdown zones require light for germination. An adequate seed bed is one in which seeds are within or on firm contact with the soil in order to provide moisture during germination and establishment. Seeds that require burial for germination should be placed deep enough to prevent rapid drying, but shallow enough to allow for natural emergence.

Timing of seeding can play a major role in seedling germination and establishment. Fall seeding is a common practice for upland buffer plantings because most mixed grass prairie species are cool season perennials. These species require exposure to cold, moist conditions to overcome seed dormancy during winter months so that they can germinate and establish during the following spring.

However, wetland species with a light requirement for germination are not well suited to fall seeding. Fall seeding can allow wetland seeds to float or blow into safe sites, but establishment the following spring is usually highly localized. Due to their small size, they can be easily lost by predation or by wind or water transport away from the site. In these cases, some restoration practitioners can "prime" seeds with cold, moist stratification and sow them during late spring and early summer months (Kettenring and Galatowitsch 2007). Priming involves using a combination of temperature and moisture to initiate dormancy break and early internal stages of seed germination and then seeds are dried to suspend germination. Priming is especially beneficial if seeds are sown during spring months or if some species in the seed mix exhibit complex dormancy mechanisms. This technique is useful on sites where weed colonization is a concern by providing a slight competitive advantage to native seeds.

Spring seeding will require that that seed pretreatments such as cold, moist stratification are done well in advance of the spring sowing date. Some wetland species can exhibit dormancy loss in as little as 60 days, while other species can require several months of cold, moist stratification. Timing of seeding requires considering the optimum temperature range required for germination. Although there can be slight differences in germination temperature requirements among similar species (Brandel 2006), most northern temperate wetland species germinate to higher percentages under fluctuating day/night temperatures, generally with at least a 10 to $15^{\circ} \mathrm{F}$ diurnal temperature difference. 
The most common and economical method for distributing seeds in wetland restoration projects is broadcast seeding. This seeding method allows the planter to selectively seed microsites to maximize germination and establishment potential in safe sites, resulting in a more patchy distribution of germinants. Seeding should be done by individuals who have an understanding of the species being sown and their ecological requirements for germination so that valuable seeds are sown in the best possible locations for establishment. Broadcast seeding also allows the seeder to "spot-seed" species or seed small quantities into strategic microsites. However, this seeding method has several disadvantages for broad-scale reseeding efforts. The only way to cover seeds is to manually rake them into the topsoil or to apply mulches to ensure soil/seed contact. This is necessary to limit seed loss by wind, water, and animal predation. Otherwise, larger quantities of seeds will need to be sown to ensure that enough find safe sites for germination.

If the seeding area has been prepared with a roughened soil surface, seeds can fall on many safe sites, which may lead to higher rates of germination and establishment. Preparing the soil bed by ensuring that the surface is roughened and loose rather than smooth and packed can significantly increase seed germination and establishment (Desserud 2006, Majerus 2006). This technique in combination with the use of seed mulch can dramatically increase seed germination in upland buffer plantings (Majerus 2006). Roughened soil bed preparation, manual broadcast seeding, and mulches will add significantly to reseeding costs and efforts, but may be warranted if all seeded native species establish on the restoration site.

Seeding rates are determined by project objectives, life history of the species in the mix, seed dormancy mechanisms, known germination rate, and other factors. The seeding rate is the amount of seeds of each species in the mix. Each species requires accurate calculations of the total number of pounds or ounces of seeds needed in each mix. Formulas are based on the amount of pure live seed per pound of bulk seeds, desired seedling density, percentage of density composed of each species, and area size (Steinfeld et al. 2007). Another important factor to consider is estimated seedling survival. Pure live seed is usually found on commercial seed labels or is available from growers of custom seed lots. Estimating first year survival is difficult; however, assessment of favorable seed germination conditions can be made by evaluating environmental conditions at the project site, forecasted weather conditions during the year of initial establishment and site preparation.

Factors to consider in estimating seedling survival include seed cover, spring rainfall, humidity, soil water holding capacity, sowing method used, season of sowing, erosion potential, and aspect. Desired seedling density is the desired number of plants per square foot the first year after sowing. For example, if one of the project objectives is to limit the establishment of non-native species or prevent soil erosion, a higher seeding density rate may be used. Density is also determined by growth rates of the species in the seed mix. An example native seed mix from the outermost drawdown zone of a depressional wetland may be $50 \%$ western wheatgrass, $35 \%$ inland saltgrass, and $15 \%$ cordgrass. The amount of seeds required will depend on each species in the seed mix, the desired seeding rate per species, and the total acreage to be seeded.

\section{Agricultural Wetland Conservation plantings}

The main objective for any restoration project in the PPR is the maximum recovery of wetland hydroperiod. Agricultural wetland conservation plantings must establish a native mixed grass community in the upland buffer, with appropriate 
species composition and structure. In the past, inappropriate pasture grass species have been used for conservation plantings, with negative influences on depressional wetland hydrology. Although native cultivars or improved native strains have been recommended in the past, they can pollute local gene pools and potentially displace natural populations. Introduced perennial cover crops such as perennial rye and smooth brome should be avoided in wetland conservation plantings. All of these species are tall statured and can impact wetland hydrology. Watershed scale wetland restoration projects are likely to occur over a several year period, so there is adequate time available to collect locally adapted seed sources. These collections can be used as for bulk seed increase efforts.

"Regreen" is a sterile hybrid cross of common wheat and wheatgrass that provides erosion control, establishes quickly, and does not reseed or persist beyond the first year. Slender wheatgrass (Elymus trachycaulus) is a native species that germinates and establishes rapidly and provides effective cover, if it is seeded at a higher rate. These grasses, in combination with other native grasses and forbs, can provide sufficient cover to minimize soil erosion, reduce weed competition, and facilitate establishment of other seeded native species. Other short statured native species that are common in mixed grass prairie include blue grama (Bouteloua gracilis), western wheat grass (Pascopyrum smithii), prairie junegrass (Koeleria micrantha), Idaho fescue (Festuca idahoensis), and Sandberg's bluegrass (Poa secunda).

Many native upland perennial forbs are suitable for inclusion in the upland buffer seed mix. Forbs are an essential component of the plant community and their establishment adds species diversity and additional erosion control benefits. An increased base of both native grasses and forbs in the seeding mix can lead to higher rates of colonization and productivity (Foster and Dickson, 2004), and species diversity may limit the establishment of some aggressive exotic forbs. Common species include scarlet globemallow (Sphaeralcea coccinea), western sagewort, (Artemisia ludoviciana), yarrow (Achillea millefolium), aster (Symphyotrichum species), dalea (Dalea species), lupine (Lupinus argenteus, L. sericeus), among others. Again, reference grassland community types, soils, and other site conditions will determine forb species composition and seeding rate. Prior to seeding, hard seeded species will require scarification to optimize seed germination. Forb seeds and small seeded grasses are small and are best established by hand-broadcast seeding. Seeds can be broadcast sown following drillseeding of native perennial grasses.

However, future research may indicate that broadcast seeding methods may be preferable to drill-seeding native perennial grasses (Yurkonis et al. 2010). This may be especially true in the western PPR, where extensive use of crested wheatgrass as a cover crop has resulted in the alteration of rangeland prairie and persistence of crested wheatgrass in agricultural areas. Careful attention to seed bed preparation, seeding method, seeding rate, grazing, and selective herbicide treatments can foster the establishment of native species in crested wheatgrass stands. The combination of methods, as well as timing, may produce variable results and among grassland community types (Pokorny and Mangold 2009, Fansler and Mangold, 2011). In one study, both clipping (which simulated grazing) and herbicide treatments reduced crested wheatgrass cover. Cover was significantly decreased with increasing cover of seeded blue grama, and clipping reduced crested wheatgrass cover by $90 \%$ while doubling total native cover (Wilson and Pärtel, 2003).

Reseeding techniques, both in wetland and upland plantings, will require additional research to determine the best management practices for native species establishment. Methodology, timing, seed prescriptions and post management may vary 
greatly between favorable wet years and during dry years.

\section{Summary}

The limiting factors at the restoration site are very instructive in choosing stock types and preparing optimal conditions at the site to maximize plant survival and growth. Often, limited water availability during summer months following drawdown and spring runoff can be a factor. Thus, the outplanting window is narrowly confined to a brief period during late spring or early summer months, when water levels have dropped enough to allow installation of the plants but when there is still available soil moisture to sustain them through the first growing season. This site condition can define the stock types selected, how the stock types are conditioned and prepared for planting, and the tools and labor used for proper installation. Appropriate timing of planting and seeding will ensure that expensive revegetation efforts are maximized to the greatest extent possible.

How plants are physiologically conditioned, stored, handled, and cared for at the nursery, during transport, temporary storage, and installation all contribute significantly to the potential for survival and growth. Delineating planting areas based on differences in hydrological regimes, soils, and plant community boundaries will greatly facilitate high nursery stock survivability and establishment of seeds. Finally, following the proper planting and seeding techniques and selecting microsites within the planting area ensure that all steps have been taken to ensure high survivability and growth. This is especially important because most wetland and riparian plants occur in distinct zones based on hydrology and soils. The ultimate goal is to take all necessary steps to promote high survival and establishment on the restoration site. 


\section{Chapter 9: Restoration Monitoring}

Long-term monitoring is a vital component of any restoration project. Restoration monitoring helps to identify whether restoration goals and objectives are being met; to detect problems before they compromise the success of the project; and to document abiotic and biotic responses to different restoration activities. Monitoring also serves an important function in advancing our understanding of restoration in disturbed wetland and riparian systems. Results can be shared to inform and improve restoration techniques and post-restoration management on similar sites

\section{Developing a Monitoring Plan}

There are 12 important steps involved in developing a monitoring plan. These can be conceptualized as follows:

\section{Link monitoring to restoration goals and objectives.}

The purpose of monitoring is to establish a dataset that adequately reflects whether the goals of the restoration project are being met. If the restoration involves compensatory mitigation for a specific wetland function, or a suite of ecosystem services, the goal will be attainment of the function or the ability to provide the services. If the restoration is part of a voluntary effort to reestablish biodiversity in an area, the goal may be development of a mosaic of habitats and communities. In either case, the first step in developing a monitoring plan is a clear statement of project objectives and desired future conditions. If desired future conditions can be stated in in quantitative terms, this will greatly facilitate development of performance objectives, allowing them to be crafted as thresholds for determining whether desired conditions are being met. Because monitoring plans are so closely tied to project goals, the best time to develop the plan is at the start of the restoration.

\section{2) Define the structure and function of the wetland type being restored.}

In wetland restoration, function does not always follow form. For example, in a North Dakota study of nesting waterfowl, multi-species planting of native plants, while producing the desired structure for nesting, did not support late season nesting success, and may have acted as an ecological sink for nesting birds. Most native plant species are best adapted to early season conditions, and no longer provide the kind of structure that supports successful nests as they senesce (Haffele 2012). When function is dependent on structure, as would be the case if the goal were to support macroinvertebrate biodiversity, then defining targets for both is equally critical (Mabry and Dettman 2010).

\section{3). Select reference sites for monitoring.}

In earlier chapters, we stressed that identification of appropriate reference sites can help identify attainable goals for structure and function. These sites can also provide quantitative targets for measuring specific indicators. Moreover, identification of reference sites subject to similar environmental conditions will make it easier to determine whether a failure to meet a specific restoration goal is due to the restoration practices or larger-scale environmental patterns. Because of the extreme natural variability found in wetland ecosystems, identification of multiple reference sites is preferable. However, these should all be similar in type, landscape context, hydrology, dominant soils and size to the wetland being restored. Selection and monitoring of reference sites will be discussed in further detail below. 


\section{4) Determine the monitoring budget.}

All aspects of monitoring, including frequency, parameters to be measured, techniques and protocols to be used, and data analysis, will need to occur within any budget constraints. While it might be desirable to measure water table fluctuations within restored and reference wetlands on a weekly basis over the course of a season, doing so will require numerous site visits (time costs) or instrumentation (material costs).

Knowing budget parameters at the outset will help in prioritizing what can and will be monitored.

\section{5) Identify feasible monitoring frequency, duration, and time period.}

Although frequent monitoring may be desirable to check on water control structures, soil stabilization measures, instruments (if any), and signs of erosion or sedimentation, location of the restoration site will often determine how often (frequency), how long (duration) and when monitoring will occur. Remote sites will, of necessity, be sampled less frequently, with monitoring activities ideally limited to a single day in the optimum season. However, the optimum time for monitoring specific responses or particular functions will vary. If restoration occurs in the spring, the best time of year for initial vegetation monitoring is in the fall, when full growth following outplanting has occurred for the year and first-year mortality rates are measurable. Over the longer term, if vegetation monitoring is a key focus, the best time of year to capture the full range of plant species present in monitoring plots is late June to July, when the greatest number of species are in flower and easily identifiable. If habitat use is a desirable indicator, the time period for monitoring may be driven by the species of interest. All these factors need to be incorporated into the monitoring plan.

\section{6) Develop performance objectives and indicators.}

The restoration goals defined in Step 1 will aid in developing performance objectives. Indicators are measured to assess progress towards meeting those objectives. A typical restoration goal is to return the restored site to close approximation of its natural, undisturbed condition. A performance objective might be "By year 2, the vegetation of the site will be dominated by hydrophytes." The indicator might be "percent cover of obligate and facultative wetland plants." It is especially important to identify objectives and indicators that will also capture underlying problems at the restoration site (Mathews and Endress 2008). For example, if a site is dominated by hydrophytes but has a high cover of invasive non-natives, it is likely to achieve its restoration goals. Therefore, planners need to anticipate both indicators of success and indicators of problems in setting performance objectives.

\section{7) Select restoration methods and techniques for effectiveness monitoring}

Because restoration science is still a developing field, restoration planners are often testing out new approaches and methods, and in many cases, restoration will involve more than one approach to remedying a specific problem. In Chapter 7, for example, we discussed biodegradable erosion control mats and hydromulches for improving soil stability. While fixing a particular problem may be a minor restoration objective compared to the overall goal, a quantitative assessment of the success of a new technique, or a comparison of similar products, may provide invaluable information in another restoration.

\section{8) Describe any limiting factors that need to be tracked during restoration monitoring.}

In Chapter 4, we defined limiting factors as any conditions that limit or exceed the tolerance and 
adaptation of an individual species or plant community, such as adjacent land use, water availability, water quality, or poor upland condition. In many cases, restoration planning and implementation will address these factors directly. However, in some cases, limiting factors will not be discovered, or not develop, until the restoration has been implemented. While developing the monitoring plan, it is helpful to generate a list of potentially occurring limiting factors (e.g., future drought, nearby energy development, wildfires, change in ownership/management of adjacent lands) and strategies for keeping ahead of them.

\section{9) Choose a monitoring protocol.}

In Chapter 4, we discussed some of the protocols available for wetland assessment. Depending on the time, budget and personnel available for restoration monitoring, any of these protocols can be used to measure progress in the post-restoration stage, and can be added to as necessary. No matter which protocol is chosen, however, it is important to use it consistently throughout the process, so that pre-restoration conditions can be documented, and change can be monitored through time. We discuss monitoring protocols in greater detail in the next section.

\section{0) Identify any testable hypotheses and statistical methods to be used.}

For pre- and post-restoration comparisons, it is valuable to have a null hypothesis (i.e., no difference before and after restoration) for each goal identified in the planning phase, and to know what statistical tests will be used to measure it. For example, a goal of increased native species richness would have the null hypothesis of "there is no difference between pre-restoration and postrestoration native species richness." This could be tested by comparing the number and foliar cover of species in $1-\mathrm{m}^{2}$ plots, using an analysis of variance (ANOVA) or comparable test. Again, consistency in analysis is vital, so that results can be tracked and compared over time. A good introductory statistics text, or a friendly statistician, can help identify appropriate tests for your hypotheses. While it may be tempting to skip this step, identifying statistically significant changes between pre- and post-restoration differences will be more credible than using qualitative measures or statements like "species richness appears to have increased."

\section{1) Create a Quality Assurance and Quality Control (QA/QC) plan.}

A QA/QC plan outlines what will be done, how it will be done, the measures used to protect the integrity of the data collected during monitoring, and the steps to be followed if anything goes wrong. It should be provided to all members of the restoration team, the funders, and all interested stakeholders. The QA/QC plan should include provisions for sampling, data handling, data management and storage, adaptive responses (e.g., steps to be taken if a water control structure fails, or if non-native plants begin colonizing the site), and should also identify all parties who are to be kept informed of progress or changes.

\section{2) Decide how information will be shared.}

The Montana Department of Transportation, which is actively involved in creating wetland mitigation sites to offset impacts of road building, maintains a website with links to all its mitigation projects, including photos and monitoring reports (http:// www.mdt.mt.gov/publications/datastats/ wetlands.shtml ) While not all restoration planners will have the resources needed to maintain websites, there should be some means of sharing information beyond immediate participants and stakeholders: annual reports, presentations at professional meetings, journal articles, etc.

Determining how this will be done at an early stage will help guide data collection and analysis, while the sharing itself will make project results useful beyond the immediate site. If plot data and/or 
species observations are being collected, these can be shared through the Montana Natural Heritage Program.

\section{Tailoring Monitoring Protocols to Specific Needs}

The most important elements in monitoring include documenting community structure and processes at the restoration site; understanding and mapping the relationships between the restoration site, the connecting wetland complex, and adjacent landscape or buffer zone; and recording the expected and unexpected changes following restoration activities. If adaptive management approaches are used, monitoring should also track specific treatments and their level of effectiveness given the site's environmental and biological parameters.

Most existing assessment protocols can be adapted for post-restoration monitoring. The advantage of using an existing protocol is that project data can be compared against data collected across a range of disturbance gradients in many different kinds of wetlands. Most of the protocols in use in Montana have been developed over several years, with feedback from multiple users and experience gained in a variety of situations, and thus are welltested and well-documented.

Nevertheless, particular situations may require that existing protocols be expanded to capture specific data, or may be simple enough that use of intensive assessment methods is overkill. Generally, the scope or level of monitoring required for a restoration project will vary with the intensity of restoration activities used to bring back key components of ecosystem function. For example, in some situations, restoration may be limited to removing stressors and allowing the system to recover on its own. In others, restoration may require substantial manipulation of soils, topography, hydrology and vegetation. Generally speaking, the more complex the restoration activities, the more complex monitoring protocols will need to be. For example, qualitative or semiquantitative measures of hydrologic function may suffice for restoration projects where no hydrologic modification was necessary to maintain wetland processes in the restored wetland. By contrast, if hydrologic alterations were necessary, their success will need to be assessed through careful and precise measurement. Dipwell monitoring with either manual or automatic loggers may be necessary to track whether hydrologic modifications are working (e.g., not leaking), to determine whether natural patterns of inundation and drawdown are being achieved, and whether the restoration site hydrology meets the criteria for a wetland (Large et al. 2007). Similarly, water level monitoring may be useful to explain patterns in vegetation establishment and success (Meyer et al. 2008, Johnson et al. 2012). Typical assessment protocols are intended for point-in-time monitoring, rather than continuous monitoring, so tracking water levels over a season will be beyond their scope. In these situations, additional monitoring protocols (e.g. WRAP 2000) will need to be located, adapted, and followed.

Adaptation of protocols may also be necessary where extensive vegetation manipulation is required. While rapid assessment (i.e., Level 2) metrics like prevalence of hydrophytic vegetation or absence of noxious weeds might suffice for vegetation monitoring when restoration activities have been limited to reducing or removing stressors, complex revegetation projects will require more detailed methods. The general goal of monitoring revegetation plantings is to determine whether the plantings are achieving defined future conditions over time and to identify any needed corrective actions. Common revegetation objectives include accelerating reestablishment of native plant community associations, decreasing 
available space for invasion by non-native species, augmenting species that have little potential to recruit or disperse into the site, and reducing sedimentation or erosion. The effectiveness of revegetation plantings can be measured by tracking plant survival and growth. In addition to quantitative counts (for density or cover), measurement of height and rate of spread (for growth), and a qualitative estimation of condition (for outplanting survival), revegetation monitoring usually requires a survival count. These data can be used to measure growth responses between revegetation treatments, stock types, seeding rates, and plant growth and spread over time. Measuring plant growth attributes is usually restricted to a particular species of interest, or to one or two species that are the dominant species in the seeding mix or planting. Depending on project objectives, revegetation monitoring may be relatively simple, or incorporate sophisticated statistical sampling designs and data collection methods, (Steinfeld et al. 2007), including measurements of tissue nutrient concentrations and nutrient standing stocks (Ray et al. 2012).

\section{Other Monitoring Considerations}

Successful restoration of plant communities takes time, and monitoring must continue for several years. Even when native species are used in the restoration, post-restoration community diversity may be lost over time. For example, in a study of mitigation wetlands in Illinois, Matthews and Spyreas (2010) found that vegetation in restored wetlands became more similar to vegetation in reference wetlands over an initial four-year monitoring period, but over a longer time frame began to converge towards conditions found in degraded wetlands, primarily due to invasion by exotic Phalaris arundinacea. If restored wetlands are in proximity to wetlands that have been colonized by aggressive exotics, those propagules may overwhelm propagules of native species once early successional and annual (native) species start to drop out. Therefore, restoration planners should prepare a long term adaptive monitoring scheme that provides an opportunity for detection of, and response to, invasive exotics into the restored wetland.

We note here that while vegetation is the most commonly measured indicator in wetland restoration, it should not be relied on to the exclusion of other attributes. If vegetation responses do not meet objectives, restoration practitioners will have no way of assessing what went wrong if vegetation is the only parameter being tracked. Were there differences in water tables or water fluctuation between the reference wetland and the restored wetland? Did the buffer around one wetland exhibit different structural features than the buffer around the other? Were there variations in nutrient availability (Matthews et al. 2009)? The only way to draw inferences about cause and effect is to monitor a suite of parameters, including but not limited to landscape context, vegetation, hydrologic and soil characteristics, water and soil chemistry, and stressor impacts. Any monitoring protocol, whether chosen from available assessment methods or developed for a specific restoration, has to be comprehensive enough to provide information on why observed values may be deviated from what is expected, while still making room for new monitoring questions to be added as unexpected circumstances arise.

Herrick et al. (2006) also note that monitoring of ecological processes can foreshadow problems before they manifest themselves in a downturn of plant community presence, density, biomass or cover. Conversely, if ecologic dynamics at a site are mimicking or approaching those found at reference sites, they can offer assurances about the likelihood of longer-term success of revegetation even though recovery is slower than anticipated. Monitoring of hydrologic processes and soil 
stability can be relatively simple, using semiquantitative visual indictors (e.g., MTNHP 2010b); the important thing is that it is done consistently, and throughout the entire monitoring program lifespan.

Finally, although detailed discussion of alternate biological indicators is beyond the scope of these guidelines, we encourage restoration practitioners to consider formal or informal monitoring other biotic communities in addition to vegetation. Even when the ultimate restoration goals do not include increases in amphibian diversity (Dixon et al. 2011) or presence of grassland birds or other wildlife (Block et al. 2001), observations of these trends will be of interest to other practitioners, as well as wildlife managers.

\section{Using Photo Points for Qualitative Monitoring}

Sometimes, budget constraints and/or project scope limit available monitoring designs and methods to simple qualitative monitoring. Qualitative monitoring of plant communities can provide a time-lapse record of change following restoration treatments. The most common, costeffective method is the use of permanent photo points. Indeed, even when comprehensive monitoring can be implemented, photo points should be established for all restoration projects to document the site's recovery over time. Pre- and post-restoration photos are invaluable for visually portraying large-scale changes in response to restoration activities, allowing a large amount of information to be captured and conveyed in a straightforward manner. Following these pointers will help ensure that pre- and post-restoration photos capture the level of information desired.

- Photo points should be selected and established in the earliest stages of the project. This will allow pre-restoration photos to be taken for all seasons.
- Photo points should be permanently marked to facilitate ease in future relocation and identification. Once selected, photo points should be recorded with accurate GPS coordinates and accurately described in a field note book.

- Long-view photos representative of the entire project area (or large portions thereof) must have a distinct, permanent landmark in the background such as a mountain peak or rock outcrop.

- Photo point locations should be easily relocated and accessible.

- Make certain that future plant growth will not obscure view.

- Select photo point sites that will portray the level and depth of information applicable to the project .

- Record all information on photo log forms. Forms must include: the project name and location; photo point number and location; direction of photo (N,S,E,W); photograph date, time, and weather conditions; photographer's name; dates of previous photos, if known; and any comments/notes by the photographer.

\section{Summary}

Monitoring requires a commitment of time and funding throughout a project's lifespan, beginning during the project planning stage and extending several years past completion. Monitoring objectives and goals should be defined in the early stages of the project, and established protocols should be followed for sampling methods, data collection, data interpretation and use. It is very important to share monitoring results so that adjustments to management practices can be made and outcomes can be improved. Monitoring requires a basic understanding of the ecological 
characteristics of the plant species, plant, invertebrate and vertebrate communities using wetland habitats in the area, the impacts or restoration treatments measured, as well as the natural and anthropogenic disturbances acting upon the restoration site. Sampling strategies must be repeatable and meaningful in terms of project objectives and measuring changes in ecosystem condition. Additional components of the restoration wetland need to be concurrently monitored including changes in water quality, invertebrates and wildlife use. Baseline measurements prior to restoration can be used to monitor water quality recovery and changes or accumulations of invertebrate and wildlife species.

Most restoration sites in the western PPR are influenced by a complex array of stressors and levels of disturbances. Many are highly variable communities, affected by seasonal and annual variables such as water depth, water chemistry and other environmental factors. Measuring vegetation recovery and restoration treatments requires that the full range of complexity be addressed in the monitoring objectives. The monitoring strategy must include feedback loops and mechanisms to incorporate results into a realistic adaptive management framework. Longer term monitoring will provide invaluable data to improve restoration practices especially in response to climate change. Measuring these changes through regional wetland reference site networks can result in adaptive restoration practices and more effective regional conservation planning.. 


\section{Literature Cited}

Alliende, M.C. and J.L. Harper. 1989.

Demographic studies of a dioecious tree:

1.Colonization, sex and age structure of a

population of Salix cinerea. Journal of Ecology

77:1029-1047.

Andreas, B. K., J. J. Mack, and J. S. McCormac.

2004. Floristic quality assessment index (FQAI) for vascular plans and mosses for the State of Ohio.

Ohio Environmental Protection Agency, Division of Surface Water, Wetland Ecology Group,

Columbus, Ohio.

Argus, G.W. 1965. Preliminary reports on the flora of Wisconsin. No. 51, Salicaceae. The genus Salix. Wisconsin Academy of Sciences, Arts, and Letters $53: 217-272$.

Arndt, J. and J. Richardson. 1988. Hydrology, salinity and hydric soil development in a North Dakota prairie-pothole wetland system. Wetlands 8 (2): 93-108.

Barrat-Segretain, M.H., G. Bornette, and A. Hering -Vilas-Bôas. 1998. Comparative abilities of vegetative regeneration among aquatic plants growing in disturbed habitats. Aquatic Botany 60 (3):201-211.

Baskin, C.C. and J.M. Baskin. 1998. Seeds: Ecology, Biogeography and Evolution in Dormancy and Germination. Academic Press, San Diego, CA. 666 p. ISBN 0-12-080260-0

Batt, B. D. J., M. G. Anderson, C. D. Anderson and F. D. Caswell. 1989. The use of prairie potholes by North American ducks. Pages 204-227 in Northern prairie wetlands (A. Van der Valk, Ed.). Iowa State University Press, Ames. 400 pp.
Berglund, J. and R. McEldowney. 2008. MDT Montana Wetland Assessment Method. Post, Buckley, Schuh and Jernigan. Helena, MT. 42 pp.

Bischoff, A., T. Steinger, and H. Müller-Schärer. 2010. The importance of plant provenance and genotypic diversity of seed material used for ecological restoration. Restoration Ecology. 18: 338-348.

Boedeltje, G., G.N.J. ter Heerdt, and J.P. Bakker. 2002. Applying the seedling-emergence method under waterlogged conditions to detect the seed bank of aquatic plants in submerged sediments. Aquatic Botany 72:121-128.

Bothe, H., T. Katarzyna and R. Marjana. 2010. The potential role of arbuscular mycorrhizal fungi in protecting endangered plants and habitats . Mycorrhiza 20(7): 445-457.

Bradley, C.E., and D.G. Smith. 1986. Plains cottonwood recruitment and survival on a prairie meandering floodplain, Milk River, southern Alberta and northern Montana. Canadian Journal of Botany 64(7):1433-1442.

Brandel, M. 2006. Effect of temperatures on dormancy and germination in three species in the Lamiaceae occurring in northern wetlands. Wetlands Ecology and Management 14 (1): 11-28.

Brinson, M. 1993, A hydrogeomorphic classification for wetlands. Technical Report WRPDE-4, US Army Corps of Engineers, Wetlands Research Program, Washington, DC.

Brunsfeld, S.J., and F.D. Johnson. 1985. Field Guide to the Willows of East-Central Idaho. University of Idaho College of Forestry, Wildlife and Range Sciences Bulletin No.39. University of Idaho Press, Moscow, Idaho. 95 p.

Budelsky, R. A. and S. M. Galatowitsch. 2004. Establishment of Carex stricta Lam. seedlings in experimental wetlands with implications for 
Budelsky, R. A. and S.M. Galatowitsch. 1999. Effects of moisture, temperature, and time on seed germination of five wetland carices: implications for restoration. Restoration Ecology. 7: 86-97.

Burkett, V.R. and Kusler, J. 2000. Climate change: potential impacts and interactions in wetlands of the United States. Journal of the American Water Resources Association, 36(2):313320.

Chadde, S.W., J.S. Shelly, R.J. Bursik, R.K. Moseley, A.G. Evenden, M. Mantas, F. Rabe, and B. Heidel. 1998. Peatlands on National Forests of the Northern Rocky Mountains: ecology and conservation. General Technical Report RMRSGTR-11, U.S. Department of Agriculture, Forest Service, Rocky Mountain Research Station, Ogden, Utah.

Cohen, D., M. Person, R. Daanen, S. Locke, D. Dahlstrom, V. Zabielski, T. C. Winter, D.O. Rosenberry, H. Wright, E. Ito, J.L. Nieber, and W.J. Gutowski Jr. 2006. Groundwater-supported evapotranspiration within glaciated watersheds under conditions of climate change. Journal of Hydrology 320:484-500.

Comer, P., D. Faber-Langendoen, R. Evans, S. Gawler, C. Josse, G. Kittel, S. Menard, M. Pyne, M. Reid, K. Schulz, K. Snow, and J. Teague. 2003. Ecological Systems of the United States: A

Working Classification of U.S. Terrestrial Systems. NatureServe, Arlington, VA.

Comes, R.D., V.F. Bruns, and A.D. Kelley. 1978. Longevity of certain weed and crop seeds in fresh water. Weed Science 26(4):336-344.

Connelly, T. 2010. Personal communication. Wildlife Biologist, U.S. Fish and Wildlife Service, Medicine Lakes National Wildlife Refuge, MT.

Covich, A.P., S.C. Fritz, P.J. Lamb, R.D., Marzolf, W.J. Matthews, K.A. Poiani, E.E. Prepas, M.B. Richman, and T.C. Winter. 1997. Potential effects of climate change on aquatic ecosystems of the Great Plains of North America. Hydrological Processes 11:993-1021.

Cowardin, L.M., V. Carter, F.C. Golet, and E.T. LaRoe. 1979. Classification of Wetlands and Deepwater Habitats of the United States. U.S. Fish and Wildlife Service Report No. FWS/OBS/-79/31, Washington, DC.

Crawford, R.M., and J. Balfour J. 1983. Female predominant sex ratios and physiological differentiation in arctic willows. Journal of Ecology 71:149-160.

Cronk, J. K., M. S. Fennessy. 2001. Wetlands plants: biology and ecology. CRC Press, Boca Raton, FL.

Dahl, T.E. 1997. Status and trends of wetlands in the conterminous United States 1986 to 1997. U.S. Department of the Interior, Fish and Wildlife Service, Washington, D.C. 82 pp.

DeKeyser, E.S., D.R. Kirby, and M.J. Ell. 2003. An index of plant community integrity: development of the methodology for assessing prairie wetland plant communities. Ecological Indicators 3:119133.

DeKeyser, E.S., M. Biondini, D. Kirby and C. Hargiss. 2009. Low prairie plant communities of wetlands as a function of disturbance: physical parameters. Ecological Indicators 9:296-306.

Desserud, P.A. 2006. Restoration of rough fescue grassland on pipelines in southwestern Alberta. Rangeland Management Branch, Public Lands Division, Alberta Sustainable Resource Development, Lethbridge, Alberta. Publication No. $\mathrm{T} / 121.68 \mathrm{pp}$.

Devries, J.H. and L.M. Armstrong. 2011. Impact of Management Treatments on Waterfowl use of Dense Nesting Cover in the Canadian Parklands. Journal of Wildlife Management 75(6):1340-1349. 
Dixon, A.D., W.R. Cox, E.M. Everham and D.W. Ceilley. 2011. Anurans as biological indicators of restoration success in the Greater Everglades Ecosystem. Southeastern Naturalist 10(4)629-646.

Dorn, R.D. 1974. A systematic study of some North America Salix. Ph.D. dissertation, University of Wyoming, Laramie, Wyoming.

Dreesen, D., and G. Fenchel. 2008. Deep planting methods that require minimal or no irrigation to establish riparian trees and shrubs in the Southwest. Journal of Soil and Water Conservation 63(4):129133.

Dreesen, D., J. Harrington, P. Stewart, T. Subirge, and G. Fenchel. 2002. Riparian restoration in the Southwest - species selection, planting methods and case studies. In: National nursery proceedings1999, 2000, and 2001. Dumroese, R.K., L. E. Riley, and T.D. Landis. USDA Forest Service, Rocky Mountain Research Station, Proceedings RMRS-P-24. 370 p.

Dumroese, K.D., J. Pinto, T. Luna, T.D. Landis, and A.C. Davis. 2011 (Draft version). Native plant propagation protocols: a guide for tribal nurseries. Agricultural Handbook 730. USDA Forest Service, Washington, DC. Volume 2.

Dumroese, K.D., T. Luna, and T.D. Landis (editors). 2009. Nursery manual for native plants: a guide for tribal nurseries. Agricultural Handbook 730. USDA Forest Service, Washington, DC. 302 pp.

Euliss, N.H. Jr., D.M. Mushet, and D.A. Wrubleski. 1999. Wetlands of the prairie pothole region: invertebrate species composition, ecology, and management. Pp. 471-514 in: Batzer, D. P., R.B. Rader, and S.A. Wissinger, eds. Invertebrates in Freshwater Wetlands of North America: Ecology and Management. John Wiley \& Sons, New York. Jamestown, ND: Northern Prairie Wildlife Research Center Online. URL: http:// www.npwrc.usgs.gov/resource/wetlands/pothole/ index.htm (Version 02SEP99) (accessed February 10, 2010).

Faber-Langendoen, D., C. Hedge, M. Kost, S. Thomas, L. Smart, R. Smyth, J. Drake, and S. Menard, 2011. Assessment of wetland ecosystem condition across landscape regions: a multi-metric approach. NatureServe, Arlington, VA. + Appendices

Falk, D. A. 1990. Integrated strategies for conserving plant genetic diversity. Annals of the Missouri Botanical Garden 77:38-47.

Fansler, V. A. and J.M. Mangold. 2011. Restoring native plants to crested wheatgrass stands.

Restoration Ecology 19: 16-23.

Foster, B.L. and T.L. Dickson. 2004. Grassland diversity and productivity: the interplay of resource availability and propagule pools. Ecology 85: 1541 $-1547$.

Fox, J.F. 1992. Pollen limitation of reproductive effort in willows. Oecologica 90:283-287.

Freeland, J.A., J.L. Richardson, and L.A. Foss. 1999. Soils indicators of agricultural impacts on northern prairie wetlands. Wetlands 19 (1): 56-64.

Froehlich, H.A., R.W. Robbins, D.W.R. Miles, and J.K. Lyons. 1983. Monitoring recovery of compacted skid trails in central Idaho. Special Report for the Payette National Forest, McCall, ID.

Galatowitsch, S. M. 2006. Restoring prairie pothole wetlands: does the species pool concept offer decision-making guidance for re-vegetation. Applied Vegetation Science. 9:261-270.

Galatowitsch, S. M. and A. G. van der Valk. 1996. The vegetation of restored and natural prairie wetlands. Ecological Applications. 6:102-12. Galatowitsch, S. M. and A. G. van der Valk. 1996b. Vegetation and environmental conditions in recently restored wetlands in the prairie pothole 
region of the USA. Plant Ecology.126 (1):89-99.

Galatowitsch, S. M., A.G. Van der Valk, and R. Budelsky. 1998. Decision-making for prairie wetland restorations. Great Plains Research 8:137155.

Galatowitsch, S. M., and A.G. van der Valk. 1998. Restoring prairie wetlands. Iowa State University Press, Ames, IA. ISBN: 0-8138-2499-0. 242 p.

GAO. 2007. Prairie Pothole Region: At the Current Pace of Acquisitions, the U.S. Fish and Wildlife Service Is Unlikely to Achieve Its Habitat Protection Goals for Migratory Birds. Report to the Subcommittee on Interior, Environment, and Related Agencies, Committee on Appropriations, House of Representatives. GAO-07-1093. Washington, DC: Government Accountability Office. 39 pp. plus appendices.

Gibbs, J. P. 1993. Importance of small wetlands for the persistence of local populations of wetlandassociated animals. Wetlands 13:25-31.

Gilbert, M.C., Whited, P.M., Clairain, E.J., and Smith, R.D. 2006. A Regional Guidebook for Applying the Hydrogeomorphic Approach to Assessing Wetland Functions of Prairie Potholes. ERDC/EL TR-06-5, U.S. Army Engineer Research and Development Center, Vicksburg, MS.

Gleason, R.A., and N.H. Euliss Jr. 1998. Sedimentation of prairie wetlands. Great Plains Research 8:97-112.

Gleason R.A., N.H. Euliss, D.E. Hubbard and W.G. Duffy. 2003. Effects of sediment load on emergence of aquatic invertebrates and plants from wetland soil egg and seed banks. Wetlands. 23 (1): 26-34.

Gleason R.A., N.H. Euliss Jr., D.E. Hubbard and W.G. Duffy. 2004. Invertebrate egg banks of restored, natural, and drained wetlands in the prairie pothole region of the United States. Wetlands. 24 (3): 562-572.

Gleason R.A., N. H. Euliss Jr., B. A. Tangen, M. K. Laubhan, and B. A. Browne. 2011. USDA conservation program and practice effects on wetland ecosystem services in the prairie pothole region. Ecological Applications 21:65-81.

Gleason, R.A., N. H. Euliss Jr.B. A. Tangen, M. K. Laubhan, and B. A. Browne. 2011. USDA conservation program and practice effects on wetland ecosystem services in the Prairie Pothole Region. Ecological Applications 21: S65-S81

Guntenspergen, G.R., S. A. Peterson, S.G. Leibowitz, and L.M. Cowardin. 2002. Indicators of wetland condition for the prairie pothole region of the United States. Environmental Monitoring and Management 78:229-252.

Haffele, R.D. 2012. Nesting ecology of ducks in dense nesting cover and restored native plantings in northeaster North Dakota. M.S. Thesis, Southern Illinois University Carbondale. Available from http://opensiuc.lib.siu.edu/theses/858/ Last accessed November 8, 2012.

Hansen, P.L., R.D. Pfister, K. Boggs, B.J. Cook, J. Joy, and D.K. Hinckley. 1996. Classification and Management of Montana's Riparian and Wetland Sites. Montana Forest and Conservation Experiment Station, School of Forestry, The University of Montana, Missoula, MT. Miscellaneous Publication No. 54.

Heidel B., S.V. Cooper, and C. Jean. 2000. Plant Species of Special Concern and Plant Associations of Sheridan County, Montana. Prepared for the U.S. Fish and Wildlife Service. Montana Natural Heritage Program. 22 pp. plus appendices.

Helzer, C.J. and D.E. Jelinski. 1999. The relative importance of patch area and perimeter-area ratio to grassland breeding birds. Ecological Applications 9:1448-1458. 
Hendricks, P., G. M. Kudray, S. Lenard, and B. Maxell. 2007. A Multi-scale Analysis Linking Prairie Breeding Birds to Site and Landscape Factors Including USGS GAP Data. Report to the United States Department of the Interior, Bureau of Land Management, State Office. Montana. Natural Heritage Program, Helena, Montana. 23 pp.

Herr-Turoff A. and J.B. Zedler. 2007. Does morphological plasticity of the Phalaris arundinacea canopy increase invasiveness? Plant Ecology. 193 (2): 265-277.

Herrick, J.E., G.E. Schuman, and A. Rango. 2006. Monitoring ecological processes for restoration projects. Journal for Nature Conservation 14:161171.

Hoag, J.C. 2000. Harvesting, propagating and planting wetland plants. Aberdeen (ID): Riparian/ Wetland Project Information Series No.14. USDA Natural Resources Conservation Service, Aberdeen Plant Materials Center.

Hoag, J.C. 2010. Personal communication. Wetland Plant Ecologist (retired), National Resource Conservation Service (NRCS), Aberdeen, Idaho.

Hong-Ren, L., L.M. Smith, D. A. Haukos and B. L. Allen. 1999. Sources of recently deposited sediments in playa wetlands. Wetlands 19 (1): 176181.

Hong-Ren, L.,L.M. Smith, B. L. Allen and D.A. Haukos. 1997. Effects of sedimentation on playa wetland volume. Ecological Applications. 7: 247252.

Johnson, W.C., B. Werner, G.R. Guntenspergen, R. A. Voldseth, B. Millet, D.E. Naugle, M. Tulbure, R.W.H. Carroll, J. Tracy, and C. Olawsky. 2010. Prairie wetland complexes as landscape functional units in a changing climate. BioScience 60(2):128140.
Johnson, Y.B., T.H. Shear and A. L. James. 2012. Identifying ecohydrological patterns in natural forested wetlands useful to restoration design. Ecohydrology 5: 368-379.

Jones, K.L., B.A. Roundy, N.L. Shaw, and A.R. Taylor. 2004. Environmental effects on germination of Carex utriculata and Carex nebrascensis relative to riparian restoration. Wetlands 24(2):467-479.

Jones, W.M. 2003. Kootenai National Forest peatlands: description and effects of forest management. Report to the Kootenai National Forest, Montana. Montana Natural Heritage Program, Helena. 14 pp. plus appendices.

Kalbitz, K.; S. Solinger, J.-H. Park, B. Michalzik, and E. Matzner. 2000. Controls on the dynamics of dissolved organic matter in soils: A review. Soil Science: 165 (4):277-304

Kaul, R.B., and M.N. Kaul. 1994. Sex ratios of Populus deltoides and Salix amygdaloides (Salicaceae) in Nebraska. Southwestern Naturalist 29 (3):265-269.

Kay, C.E., and S. Chadde. 1992. Reduction of willow seed production by ungulate browsing in Yellowstone National Park. Pp. 92-99 in: Clary, W.P., E.D. McArthur, D. Bedunah, and C.L. Wambolt, compilers. Proceedings: Symposium on Ecology and management of Riparian Shrub Communities. 1991. May 29-31. Sun Valley (ID). USDA Forest Service, Intermountain Research Station, General Technical Report INT-289, Ogden, UT.

Kettenring K.M. and S.M. Galatowitsch. 2007. Tools for Carex revegetation in freshwater wetlands: understanding dormancy loss and germination temperature requirements. Plant Ecology 193 (2): 157-169. 
Kettenring K.M. and S.M. Galatowitsch. 2011. Seed rain of restored and natural prairie wetlands. Wetlands. 31 (2): 283-294.

Kettenring, K. M. 2006. Seed ecology of wetland Carex spp - implication for restoration. PhD Dissertation, University of Minnesota- Twin Cities, St. Paul, MN, USA.

Landis, T.D. 2010. The container tree nursery manual: Volume 7, seedling processing, storage and outplanting. Agriculture Handbook 674, USDA Forest Service, Washington, DC. 199 p.

Large, A.R.G., W.M. Mayes, M.D. Newson and G. Parkin. 2007. Using long-term monitoring of fen hydrology and vegetation to underpin wetland restoration strategies. Applied Vegetation Science $10: 417-428$.

Leck, M.A. 1989. Wetland seed banks. In: Leck, M.A.,V.T. Parker, and R.L. Simpson (eds.). Ecology of Soil Seed Banks. Academic Press, Inc. San Diego, CA. pp. 283-305.

Leibowitz, S.G., and K.C. Vining. 2003. Temporal connectivity in a prairie pothole complex. Wetlands 23(1):13-25.

Leitch, J.A., and P. Fridgen. 1998. Functions and values of prairie wetlands: economic realities.

Great Plains Research 8:157-168.

Lesica, P. and S. Shelley.1988. The vegetation and flora of glaciated prairie potholes on the Blackfeet Indian Reservation, Montana. Progress Report. The Nature Conservancy Montana/Wyoming Field Office. Helena, MT. 19 pp.

Luna, T., R.K. Dumroese, and T.D. Landis. 2006. Collecting dormant hardwood cuttings for restoration projects. USDA Forest Service, Technology and Development Program. 8 p.

Mabry,C. and C. Dettman. 2010. Odonata richness and abundance in relation to vegetation structure in restored and native wetlands of the Prairie Pothole
Region, USA. Ecological Restoration 28(4):475484.

Majerus, M. 2006. Broadcast seeding demonstration. In: Plant Materials Today: Quarterly Newsletter of the Montana-Wyoming Plant Materials Program. USDA Natural Resources Conservation Service, Bridger Plant Materials Center.

Matthews, J.W. and A.G. Endress. 2008.

Performance criteria, compliance success and vegetation development in compensatory mitigation wetlands. Environmental Management 41:130-141.

Matthews, J.W., A.L. Peralta, A. Soni, P. Baldwin, A.D. Kent and A.G. Endress. 2009. Local and landscape correlates on non-native species invasion in restored wetlands. Ecography 32:1031-1039.

Matthews, J.W. and G. Spyreas. 2010.

Convergence and divergence in plant community trajectories as a framework for monitoring wetland restoration progress. Journal of Applied Ecology 47: 1127-1136.

McIntyre, C., K.Newlon, L.Vance and M. Burns. 2011. Milk, Marias, and St. Mary Wetland Monitoring: Developing a Long-term Rotating Basin Wetland Assessment and Monitoring Strategy for Montana. Montana Natural Heritage Program, Helena, Montana. 169 pp.

Meyer, C.K., M.R. Whiles and S.G. Baer. 2008. Plant community recovery following restoration in temporally variable riparian wetlands. Restoration Ecology 18(1): 52-64.

Meyerson L.A., D.V. Viola and R.N. Brown. 2010. Hybridization of Phragmites australis with a native subspecies in North America. Biological Invasions. 12 (1): 103-111.

Miller, S. J., and D. H. Wardrop. 2006. Adapting a floristic quality assessment index to indicate 
anthropogenic disturbance in central Pennsylvania wetlands. Ecological Indicators. 6:313-326.

Mitsch, W.J. and J.G. Gosselink. 2007. Wetlands, 4th ed., John Wiley \& Sons, Inc., New York.

Montana Natural Heritage Program (MTNHP) 2010. Ecological System Field Guide. Montana Natural Heritage Program Field Guide. URL: http://mtnhp.org/ http://fieldguide.mt.gov/ displayES_LCLU.aspx Last accessed October 29, 2012.

Montana Natural Heritage Program (MTNHP) 2010b. Montana Ecological Integrity Assessment Field Manual. Available from http://mtnhp.org/ wetlands/docs/Protocol.pdf. Last accessed October 29, 2012.

Moreno-Mateos, D., M.E. Power, F.A. Comín, and R. Yockteng. 2012. Structural and Functional Loss in Restored Wetland Ecosystems. PLoS Biol 10(1): e1001247. doi:10.1371/journal.pbio.1001247

Mosseler, A., and L. Zsuffa.1989. Sex expression and sex ratios in intra- and inter-specific hybrid families of Salix L. Silva Genetica 38:12-17.

Mozdzer, T. J. and J.C. Zieman. 2010.

Ecophysiological differences between genetic lineages facilitate the invasion of non-native Phragmites australis in North American Atlantic coast wetlands. Journal of Ecology. 98: 451-458.

Mueller, M. H. and A. G. van der Valk. 2002. The potential of ducks in wetland seed dispersal.

Wetlands. 22:170-78.

Mulhouse J.M. and S.M. Galatowitsch. 2003.

Revegetation of prairie pothole wetlands in the mid -continental US: twelve years post-reflooding. Plant Ecology. 169 (1): 143-159.

National Research Council (NRC). 2001. Climate change science: an analysis of some key questions. National Academy Press, Washington, D.C.
NRCS. 2002 Field Indicators of Hydric Soils in the United States, Version 5.0. G.W. Hurt, P.M. Whited, and R.F. Pringle (eds.). USDA,NRCS in cooperation with the National Technical Committee for Hydric Soils, Fort Worth, TX.

Ottenbreit, K.A. and R.J. Staniforth. 1992. Life cycle and age structure of ramets in an expanding population of Salix exigua (sandbar willow). Canadian Journal of Botany 70 (6):1141-1146.

Peet, R.K., T.R. Wentworth, and P.S. White. 1998. A flexible, multipurpose method for recording vegetation composition and structure. Castanea 63: 262-274.

Perry L. G., S. M. Galatowitsch, and C. J. Rosen. 2004. Competitive control of invasive vegetation: a native sedge suppresses Phalaris arundinacea in carbon-enriched soil. Journal of Applied Ecology. 41:151-162.

Poiani, K. A. and W.C. Johnson. 1988. Evaluation of the emergence method in estimating seed bank composition of prairie wetlands. Aquatic Botany 32:91-97.

Poiani, K.A., and W.C. Johnson. 1991. Global warming and prairie wetlands: potential consequences for waterfowl habitat. Bioscience 41 (9):611-618.

Poiani, K.A., and W.C. Johnson. 1993. Potential effects of climate change on a semi-permanent wetland. Climatic Change 24:213-232.

Poiani, K.A., W.C. Johnson, T. Timothy, and G.F. Kittel.1995. Sensitivity of a prairie wetland to increased temperature and seasonal precipitation changes. Journal of American Water Resources Association 31(2):283-294.

Pokorny, M.L. and J.M. Mangold. 2009. Converting pastureland to native plant-dominated grassland: A case study (Montana). Ecological Restoration 27: 250-253. 
Preston, T.M. 2011. Reexamining saline contamination associated with oil and gas development in the prairie pothole region, Sheridan County. M.S. Thesis. Montana State University, Bozeman, MT. Available from http:// etd.lib.montana.edu/etd/2011/preston/ PrestonT0511.pdf. Last accessed October 29, 2012. Preston,T.M., B.A. Tangen, T.L. Chesley-Preston, R.A. Gleason, S.S. Haines, M.D. van der Burg, B.D. Smith, R.S. Sojda and J.N. Thanke. 2012. Risk of contamination of aquatic resources based on spatial, chemical and geophysical assessment. U.S. Geological Survey. Professional Paper. (in press). URL: http: steppe.cr.usgs.gov/pdf/ GSA_2011_Final_Small_pdf (accessed January 31, 2012).

Pritchard, D. 2003. A User Guide to Assessing Proper Functioning Condition and the Supporting Science for Lentic Areas. USDI, Bureau of Land Management Technical Reference 1737-16, Denver, CO. 110 pp.

Ray, A.M., A. Hamilton, C. Aquino and J.C. Litts. 2012. Using vegetative nutrient stocks to compare restored and reference wetlands in the Upper Klamath Basin, Oregon. Wetlands 32:827-839.

Reinhardt A.C. and S. M. Galatowitsch. 2005. Phalaris arundinacea (reed canary grass): rapid growth and growth pattern in conditions approximating newly restored wetlands. Ecoscience. 12:569-73.

Reynolds, R. E., T. L. Shaffer, R. W. Renner, W. E. Newton, and B. D. J. Batt. 2001. Impact of the Conservation Reserve Program on duck recruitment in the U.S. Prairie Pothole Region. Journal of Wildlife Management 65:765-780

Richardson, J.L. Arndt, and J.A. Montgomery. Hydrology of wetland and related soils. 2001. In Richardson, J.L., and M.J. Vepraskas (Eds.) Wetland soils: genesis, hydrology, landscapes and classification. CRC Press, Boca Raton, FL. 417 pp.
Rowland, D.L., R. Garner, and M. Jespersen. 2002. A rare occurrence of seed formation on male branches of the dioecious tree, Populus deltoides. American Midland Naturalist 174 (1): 185-187.

Russell, G.D., C.P. Hawkins, and M.P. O’Neill. 1997. The role of GIS in selecting sites for riparian restoration based on hydrology and land use.

Restoration Ecology 5(45):56-68.

Seabloom, E.W., and A.G. Van der Valk. 2003. Plant diversity, composition, and invasion of restored and natural prairie pothole wetlands. Wetlands 23(1):1-12.

Shaffer, P., and T. Ernst. 1999. Distribution of soil organic matter in freshwater emergent/open water wetlands in the Portland, Oregon metropolitan area. Wetlands 19:505-516.

Skagen S.K., C.P. Melcher, and D.A. Haukos. 2008. Reducing sedimentation of depressional wetlands in agricultural landscapes. Wetlands 28 (3):594-604.

Society for Ecological Restoration (SER). 2004. International Science \& Policy Working Group. Version 2: October, 2004. URL: http:// www.ser.org/pdf/primer3.pdf (accessed February 1, 2010).

Soil Survey Staff. 1999. Soil taxonomy: A basic system of soil classification for making and interpreting soil surveys. 2nd edition. Natural Resources Conservation Service. U.S. Department of Agriculture Handbook 436.

Soons, M. B., C. van der Vlugt, B. van Lith, G.W. Heil and M. Klaassen. 2008. Small seed size increases the potential for dispersal of wetland plants by ducks. Journal of Ecology. 96: 619-627.

Stein, E.D., S. Dark, T. Longcore, R. Grossinger, N. Hall, and M. Beland. 2010. Historical ecology as a tool for assessing landscape change and 
informing wetland restoration priorities. Wetlands 30 (3): 589-601

Steinfeld, D.E., S.A. Riley, K.M. Wilkinson, T.D. Landis, and L.E. Riley. 2007. Roadside revegetation: an integrated approach to establishing native plants. Pub. FHWAWFL/TD-07-005. Federal Highway Administration, Western Federal Lands Highway Division, Technology Deployment Program, Vancouver, WA. 413 pp.

Stewart, R.E. and H.A. Kantrud.1972. Vegetation of prairie potholes: in relation to water quality and other environmental factors. Hydrology of prairie potholes. Geological Survey Professional Paper 585-D. Online article URL: http://library.ndsu.edu/ exhibits/text/potholes/585d.html (accessed February 10, 2010).

Stewart, R.E. and H.A. Kantrud. 1978. Classification of natural ponds and lakes in the glaciated prairie region. Bureau of Sport Fisheries and Wildlife, USDI Fish and Wildlife Service, Resource Publication 92.

van der Kamp, G. and M. Hayashi. 1998. The groundwater recharge function of small wetlands in the semi-arid northern prairie. Great Plains Research. 8: 39-56.

van der Kamp, G. and M. Hayashi. 2009. Groundwater wetland ecosystem interaction in the semiarid glaciated plains of North America. Hydrogeology Journal. 17 (1): 201-214.

van der Kamp, G., and M. Hayashi. 2009. Groundwater-wetland ecosystem interaction in the semiarid glaciated plains of North America. Hydrogeology Journal 17:203-214.

van der Kamp, G., W.J. Stolte, and R.G Clark. 1999. Drying out of small prairie wetlands after conversion of their catchments from cultivation to permanent brome grass. Hydrological Sciences. 44 (3):387-397. van der Kamp, G., M. Hayashi and D. Gallen. 2003. Comparing the hydrology of grassed and cultivated catchments in the semi-arid Canadian prairies. Hydrological Processes 17: 559-575.

van der Valk, A.G. 1978. The role of seed banks in the vegetation dynamics of prairie glacial marshes. Ecology 59:322-335.

van der Valk, A. G., R.L. Pederson, and C.B. Davis. 1992. Restoration and creation of freshwater wetlands using seed banks. Wetlands: Ecology and Management 4:191-197.

van der Valk, A.G., T.L. Bremholm, and E. Gordon. 1999. The restoration of sedge meadows: seed viability, seed germination requirements and seedling growth of Carex species. Wetlands 19 (4):756-764.

van der Valk, A.G. 2005. Water-level fluctuations in North American prairie wetlands.

Hydrobiologica. 539 (1): 171-188.

Vance, L.K. and T. Luna. 2010. GIS-guided cattle supplementation to enhance wetland condition. Unpublished report to the Natural Resource Conservation Service. Montana Natural Heritage Program, Helena, M. 57 p.

Vance, L.K. 2009. Assessing wetland condition with GIS: a landscape integrity model for Montana. A report to the Montana Department of Environmental Quality and U.S. Environmental Protection Agency. Montana Natural Heritage Program, Helena, MT. 23 p. plus appendices.

Vepraskas, M.J. and S.P. Faulkner. 2001. Redox chemistry of hydric soils. In Richardson, J.L., and M.J. Vepraskas (Eds.) Wetland soils: genesis, hydrology, landscapes and classification. CRC Press, Boca Raton, FL. 417 pp.

Voldseth, R.A., W.C. Johnson, T. Gilmanov, G.R. Guntenspergen, and B.V. Millet. 2007. Model estimation of land-use effects on water levels of 
northern prairie wetlands. Ecological Applications 17(2):527-540.

Weinhold, C.E. and A.G. van der Valk. 1989. The impact of duration of drainage on the seed banks of northern prairie wetlands. Canadian Journal of Botany 67:1878-84.

Wetland Regulatory Assistance Program (WRAP). 2000. Installing Monitoring Wells/Piezometers in Wetlands. Army Corps of EngineersTechnical Note ERDC TN-WRAP-00-02. Available for download from http://el.erdc.usace.army.mil/elpubs/pdf/ tnwrap00-2.pdf

Wetzel, P. R. and A. G. van der Valk. 1998. Effects of nutrient and soil moisture on competition between Carex stricta, Phalaris arundinacea, and Typha latifolia. Plant Ecology. 138:179-90.

White, D. and S. Fennessey. 2005. Modeling the suitability of wetland restoration potential at the watershed scale. Ecological Engineering 24 (4):359 $-377$

Wilson, S. D. and M. Pärtel. 2003. Extirpation or coexistence? Management of a persistent introduced grass in a prairie restoration. Restoration Ecology 11: 410-416.

Winter, T.C. 1989. Hydrologic studies of wetlands in the northern prairie. p. 16-55. In: A. G. van der Valk (ed.) Northern Prairie Wetlands. Iowa State University Press, Ames, IA. 400 pp.

Winter, T.C., and D.O. Rosenberry. 1995. The interaction of ground water with prairie pothole wetlands in the Cottonwood Lake area, east-central North Dakota, 1979-1990. Wetlands 15(3):193211.

Winter, T.C., and D.O. Rosenberry. 1998. Hydrology of prairie pothole wetlands during drought and deluge: A 17-year study of the Cottonwood Lake wetland complex in North Dakota in the perspective of longer term measured and proxy hydrologic records. Climatic Change 40:189-209.

Young T.P., D.P. Preston and J.J. Clary. 2005. The ecology of restoration: historical links, emerging issues and unexplored realms. Ecology Letters. 8 (6): 662-673.

Yurkonis, K. A., B.J. Wilsey, K.A. Moloney, and A.G. Van Der Valk. 2010. The impact of seeding method on diversity and plant distribution in two restored grasslands. Restoration Ecology 18: 311321.

Zasada, J.C., D.A. Douglas D.A., and W. Buechler. 2004. The genus Salix. In: Woody Plant Seed Manual (online version) URL: http:// www.nsl.fs.fed.us/wpsm/Salix.pdf (accessed 12 February 2010).

Zedler, J.B. 2000. Progress in wetland restoration ecology. TREE 15(10):402-407. 
Appendix A: Glossary of terms 
Achene - a simple one-seeded indehiscent fruit, with the seed attached to the fruit wall at one point; floating without anchorage. seen in daisy (Erigeron), sunflower (Helianthus), rose $(R o s a)$ and many other plants.

Adventitious (roots) - roots produced in an unusual or irregular position, or during an unusual time of development, as seen during the rooting of hardwood stem cuttings.

Aerated - the addition of air. Well aerated soil includes a component with large particle size (gravels and coarse sand) that increases the amount of air spaces within the soil.

Aerenchyma - specialized tissue in roots, stems, and shoots of wetland plants, consisting of large air chambers and thin walled cells adapted for internal circulation of oxygen.

After-ripening - the process of metabolic changes that must occur in dormant seeds before germination is possible.

Alkaline - soils or water having a $\mathrm{pH}$ greater than 7.0.

Amplitude (ecological) - a measure of the width, breadth, or extent of the ability of a species to occupy, persist, and reproduce in an environment.

Angiosperms - plants that produce flowers and through the process of double fertilization produce seeds enclosed in an ovary.

Annual - a plant that completes its life cycle in one growing season or one year; it germinates grows, produces flowers, sets seeds, and then dies.

Anoxic - the absence of oxygen occurring in fully saturated soils.

Anthesis - the period of time that a plant is flowering.

Apomixis - the ability of plants to produce seeds without fertilization.

Aquatic (plant) - a plant that grows partly or wholly in water whether rooted in the mud or
Asexual reproduction - reproduction without sexual union; reproduction by vegetative methods, where the resulting progeny are genetically identical to the donor plant.

Association (plant) - a term used in vegetation classification. An association implies a community with physiognomic and floristic unity, in which dominant species are those in the upper vegetation layer, and usually has one or two co-dominant species. Associations are grouped hierarchically into alliances, macrogroups and groups within the National Vegetation Classification Standard (NVC). See community (plant). association' has tended to imply a community with physiognomic as well as floristic unity, usually a climax community in which the species dominants are those of the upper vegetation layer. In this tradition an association usually has several co-dominant species association' has tended to imply a community with physiognomic as well as floristic unity, usually a climax community in which the species dominants are those of the upper vegetation layer. In this tradition an association usually has several co-dominant species.

Auxin - a plant hormone that regulates plant growth and is responsible for the development of adventitious roots in cuttings.

Berry - a fleshy fruit developed from one ovary containing one to many pistils in which the ovary wall becomes fleshy and juicy, and contains one to many seeds, as seen in serviceberry (Amelanchier) and snowberry (Symphoricarpos).

Biennial - a plant that normally requires two years to complete its life cycle; vegetative growth occurs the first year, with flowering, fruiting, and death occurring the second year.

Bisexual (flower) - male and female reproductive structures within the same flower.

Boreal - refers to the coniferous forest of the northernmost regions of the northern hemisphere. 
Bisexual (flower) - male and female reproductive structures within the same flower.

Boreal - refers to the coniferous forest of the northernmost regions of the northern hemisphere.

Botanical variety - a category in taxonomic hierarchy that is below the species and subspecies level.

Brackish (water) - highly saline or alkaline water occurring in wetlands.

Branched (cuttings) - a dormant, hardwood stem cutting, usually $0.6-1.8 \mathrm{~m}(2-6 \mathrm{ft})$ long that is outplanted directly without further treatment.

Calcareous - rock, soils, or ground water that are alkaline; usually from limestone bedrock.

Callus - a waxy, irregular mass of cells that forms at the base of cuttings in response to a wound.

Capillary fringe - the subsurface layer in which groundwater seeps up from the water table by capillary action to fill soil air pores with water.

Capsule - a dry, dehiscent fruit derived from a flower that splits open along the sutures when seeds mature; as seen in camas (Camassia), beardtongue (Penstemon), cottonwood (Populus), and many other plants.

Carr - a deciduous woodland on a permanently wet, organic soil, usually dominated by alder (Alnus), birch (Betula), or willow (Salix).

Catkin - elongated deciduous cluster (spike) of unisexual flowers without petals that are subtended by small leafy or papery bracts, seen only in woody plants such as aspen and cottonwood (Populus) and willow (Salix).

Chaff - the floral parts and other debris separated from seeds during cleaning.

Closed depression - a depressional wetland that is distinguished by being completely isolated from both the regional groundwater system and interwetland surface drainage. These occur in depressional basins found in flat, enclosed upland areas or on level shallow lake basins. The major sources of input water are precipitation and snow melt, and water loss occurs through evapotranspiration.

Coetaneous - flowers emerging at the same time as leaves.

Competition -- the interaction of two species which compete for space and resources needed for survival and growth.

Community (plant) - populations of plant species occurring within a habitat that forms a relatively uniform patch, distinct from neighboring patches of vegetation.

Conifer - a general term referring to one of four classes of gymnosperms; a cone-bearing tree or shrub such as pine (Pinus), spruce (Picea), cedar (Thuja), fir (Abies), or juniper (Juniperus).

Coniferous - woodlands or forests comprised mainly of conifer species.

Cool-season - a plant that initiates growth soon after snowmelt in early spring, flowers in mid to late spring, and often goes dormant by early to mid summer in response to summer drought.

Cool-temperature requiring - refers to seeds and the resulting young plants that require cool temperatures to germinate and grow.

Cotyledon - an embryonic seed leaf or leaves that function as food storage and may become photosynthetic when the seed germinates.

Crown - 1. the persistent base of an herbaceous perennial; 2 . the foliar part of a tree or shrub; 3 . the junction of the stem and root in a plant.

Cultivar - A contraction of "cultivated variety". It refers to a plant variety within a particular species that is distinguished by one or more characteristics. Example: Pseudoroegneria spicata "Secar".

Cultivated variety - See "cultivar" above. 
Cyme - A flat topped or round topped inflorescence in which the terminal flower blooms first.

Deciduous - plants that drop their leaves at the end of the growing season. Compare evergreen.

Decomposition - the process of breaking down organic material in interaction with atmospheric conditions, water, invertebrates and microorganisms.

Dehiscent - a dry fruit that splits open at maturity to release its seeds.

Dioecious - having male and female flowers on separate plants of the same species; species have imperfect, unisexual flowers; seen in buffaloberry (Shepherdia) and all willows (Salix), aspen and cottonwoods (Populus).

Dispersal - the scattering of seeds and fruits following maturation. Main dispersal agents include water, wind, mammals and birds, gravity and force.

Dissemination - see dispersal.

Disseminule - 1. a plant part that gives rise to a new plant; 2. appendages that aid in dispersal such as barbs, hooks, wings, parachutes or feathery appendages.

Disturbance -- change induced to a plant community due to anthropogenic stressors or natural causes.

Divisions - refers to propagating a plant by dividing it into several smaller parts, each with leaf buds, leaves, and a portion of a root system or rhizome, that are then potted separately to grow to planting size.

Dormancy (plants) - the period of inactivity in which active shoot growth has temporarily ceased due to drought or winter conditions.

Dormancy (seeds) - a term to describe seeds that do not germinate immediately after maturation and dispersal from the mother plant even when appropriate environmental conditions exist. Causes of dormancy are either internal or external, and many species have a combination of dormancy types.

Drawdown - the lowering of water level that occurs in wetlands, rivers, and streams.

Drupe - a fleshy fruit derived from a single pistil consisting of three layers: an outer skin (the exocarp), an inner fleshy layer (the mesocarp) and a hard bony stone (the endocarp) which encloses a single seed; seen in chokecherry, wild cherry and American plum (Prunus).

Ecological system - groupings of biological communities occurring in similar physical environments, and influenced by similar ecological processes such as flooding, fire, wind, and snowfall. Systems typically occur on a landscape at scales of tens to thousands of acres, and generally persist in a recognizable state for 50 or more years.

Ecotype - individuals within a species that are genetically adapted to a specific environment.

Embryo - the young intact plant within a seed.

Emergent - a plant or vegetation that grows in water but the aerial portions of shoots and leaves remain above water line.

Endocarp - the inner layer of the pericarp of a fruit.

Endosperm - the nutritive tissue surrounding the embryo of a seed.

Entisols - a soil type of relatively recent origin, distinguished by high mineral content and a lack of or very faint soil horizon development.

Erosion control - the techniques or methods used to stabilize the soil surface during restoration projects to prevent the movement or erosion of soils.

Establishment - the early stage (first few weeks) of seedling growth following germination or 
planting, in which the seedling produces the primary root, followed by the production of a secondary root mass and the first few leaves.

Evergreen - having green leaves throughout winter; not deciduous.

Exocarp - the skin of a fleshy fruit. Compare endocarp and mesocarp.

Facilitation -- describes species interactions that benefit at least one of the participants and cause harm to neither. See mutualism and nurse plant effect.

Fascine - a type of live hardwood cutting, usually multi-stem or branched, that is used to root a new plant directly on a restoration site.

Fen - a type of wetland that accumulates peat; less acidic than a bog, and deriving most of its water from groundwater rich in calcium and magnesium.

Fertilization (flower) - the union of male and female gametes.

Fibrous (roots) - a root system with all the root branches of approximately equal thickness, as seen in the grasses (Poaceae), sedges (Cyperaceae), and rushes (Juncaceae).

Floodplain - a low level plain adjacent to a river that is formed chiefly from river sediment and is subjected to periodic flooding.

Flowerhead - the inflorescence of members of the sunflower family that consists of disk flowers surrounded by ray flowers to resemble one large functioning flower. Flowerheads can also be comprised of disk flowers only or ray flowers only.

Follicle - a dry dehiscent fruit that splits open at maturity along a single side, as seen in milkweed (Asclepias).

Forb - a flowering herbaceous plant species, usually with conspicuous flowers and non-grasslike leaves. Term is usually applied to all herbaceous plants other than grasses, sedges, rushes, bulrushes, reeds, and cattails. Compare with graminoid.

Fragmentation - the asexual reproductive method found in many aquatic plants, in which stems break apart during the end of the growing season and form new plants the following year.

Fruit - a ripened ovary, and any other structures that are attached to it and ripen with it.

Genotype - individuals characterized by a certain genetic constitution. Compare phenotype.

Genus (plural Genera) - a taxonomic subdivision between the family and species, which includes one or more closely related species.

Geographically isolated wetland -- wetlands occurring in closed basins with no visible surface water connectivity to other wetlands or to streams, rivers, or lakes

Germination - the process whereby seeds or spores sprout and begin to grow.

Germination percentage - percentage of seeds that germinate during a specific period of time.

Germination rate - the number of seeds in a particular seedlot that are likely to germinate. This is usually expressed as a percentage, e.g., an $85 \%$ germination rate indicates that about 85 out of 100 seeds will probably germinate under proper conditions. Germination rate is useful in calculating seed requirements for a given area or desired number of plants.

Glomalin -- a glyco-protein produced on the hyphae and spores of mycorrhizal fungi within the soil and roots of plants, containing 30 to $40 \%$ carbon and binding organic matter to inorganic soil particles, thus contributing to improved soil structure and binding carbon from escape.

Glume - a pair of small scale-like bracts subtending a grass spikelet.

Graminoid - a herbaceous plant that typically has inconspicuous flowers and grass-like leaves, 
such as grasses, sedges, rushes, bulrushes, reeds, and cattails. Compare with forb.

Hardening - the horticultural practice of conditioning nursery plants to withstand stress. Plants are subjected to environmental and physiological conditions to withstand stress, such as exposure to ambient outdoor temperature and wind conditions during late summer, or by decreasing or modifying irrigation or fertilization practices.

Hardwood cutting - a hardwood stem section consisting of woody stem with intact dormant leaf buds that is used to root a new plant either in a nursery container or directly on a restoration site.

Head - densely packed cluster of flowers as seen in sunflower and related species.

Hedging - the horticultural practice of cutting back woody shrubs so that they generate many straight shoots the following year. These shoots are collected and used for hardwood cuttings.

Herbaceous (life form) - a non-woody plant whose stems and leaves die back to ground level at the end of the growing season; a plant without a persistent above growing woody stem. Compare woody.

Hermaphroditic - 1) an individual plant possessing male and female flowers or reproductive structures; 2) a flower with both stamens and pistils.

Hip - a fleshy fruit that surrounds several achenes, as seen in roses (Rosa).

Histosols - a soil type that forms in wetland environments consisting mostly of organic matter, such as peat based soils or mucks.

Horizon (soil) - a layer of the soil that is distinguishable from other layers in the soil profile; typically there is an $\mathrm{O}$ horizon on the soil surface, followed by an A horizon that is usually higher in organic matter content and biological activity than the underlying $\mathrm{B}$ or $\mathrm{C}$ horizons.
Hydric (soils) - soils that are saturated, flooded, or ponded long enough during the growing season to develop anoxic conditions in the upper part of the soil profile, thereby influencing the species composition or growth, or both, of plants on those soils.

Hydrology - the study of the properties, effects, and distribution of water on soils, underlying parent materials, and the atmosphere.

Hydromulch - a fine fiber mulch material that is mixed in a water based slurry and applied to the soil surface for erosion control and seeding.

Hydroperiod - the period of time a wetland is covered with water. Hydroperiods can range from regularly flooded to irregularly flooded or exposed.

Hydrophyte - a plant species adapted to growing in water either as a free-floated aquatic or rooted in mud as a submergent or emergent.

IBA (indobutryic acid) - this naturally occurring auxin is the most widely used hormone to induce rooting in cuttings.

Imbibe - when a seed swells in size when it uptakes water.

Imperfect (flowers) - flowers with ether stamens or pistils but not both; same as unisexual Compare perfect and bisexual (flowers).

Inceptisol - a soil type of older origin than Entisols, that lack an accumulation of clays, iron and aluminum and are characterized by the presence of a surface horizon rich in organic matter and a cambric subsurface horizon, weak in derived from sands or finer particles.

Inoculation - introducing spores, fungal fragments, or nitrogen fixing bacteria to plants or seeds to promote symbiotic relationships.

Inoculum - term used to describe spores, fungal fragments, or nitrogen fixing bacteria used to inoculate plants to aid in their growth. 
Indehiscent - refers to a fruit or cone that does not open at maturity.

Inflorescence - an arrangement of more than one or usually multiple flowers on a single stalk.

Internode - the area on a stem between leaf buds. See nodal, node.

Jelly-roll - a term used to describe the packing of nursery stock, where seedlings are removed from containers and the root masses are rolled together in clear plastic sheeting in order to keep the root systems moist during outplanting.

Layering - a technique of vegetative propagation where adventitious roots are formed on a stem while the stem remains attached to the plant.

Legume - 1. a member of the legume family (Fabaceae); 2. the dehiscent fruit of a legume species that splits opens along two lines at maturity; same as pod.

Leguminous - of or pertaining to members of the legume family.

Lemma - in grasses, one of the pair of bracts that subtend a grass flower. The lemma is lower, usually larger and often bears an awn. See palea.

Life history - the strategies and mechanisms which a plant uses to optimize growth, occupation of habitat, and reproductive success.

Live stake - a hardwood stem cutting that is usually $30-40 \mathrm{~cm}$ (12-16 in) long that is planted directly on the outplanting site without further treatment.

Macropore (soil) - larger pores ( $\mathrm{d}>0.08 \mathrm{~mm})$ occurring between aggregates or individual grains in coarse textured soil and may be formed by soil organisms. They allow ready movement of air and the drainage of water and provide space for roots and organisms to inhabit the soil.

Marsh - an herbaceous or forested wetland that is typically found in depressions; often adjacent to ponds, lakes, potholes, and river oxbows and having distinctive mineral soils with high organic matter content. Marshes can be seasonal or semipermanently flooded, depending on site hydroperiod.

Medium - a substrate comprised of various organic and inorganic materials used for growing plants, such as bark, sphagnum peat moss, perlite, or vermiculite.

Mesic - refers to moist habitats.

Mesocarthe -- the fleshy inner portion of a fruit. See drupe. Compare endocarp and exocarp.

Micropore (soil) - small pore spaces $(\mathrm{d}<$ $0.08 \mathrm{~mm}$ ) occurring within aggregates. They are usually filled with water and are too small to allow much movement of oxygen. Water movement in micropores is extremely slow, and much of the water held by them is unavailable to plants.

Microsite - a term used to describe small sites within a plant community that differ from the surrounding environmental conditions of the site by having great shade, wind protection, greater moisture retention, swales or pockets of low lying topography.

Mollisols - a soil type characterized as being fertile, with a deep, organic matter-rich A horizon, found in steep and grassland environments, commonly calcareous and base-rich, derived from limestone, loess or sand.

Monocarpic - flowering and bearing fruit only once and then dying. The term can be applied to annuals, biennials, or some perennials.

Monoecious - separate male and female flowers that are borne on the same plant. Compare dioecious.

Morphology (plants) - the outer structure and characteristics of a plant, such as features of the leaves, stems, roots, and flowers.

Morpho-physiological dormancy - describes seeds that have both an undeveloped embryo at 
time of seed dispersal and physiological dormancy. Seeds require a combination of conditions, often over an extended period of time, before germination occurs. See physiological dormancy; after-ripening.

Mulch - a material used to cover seeded areas to hold soil and seeds in place.

Mutualism -- two organisms of different species biologically interacting in a relationship from which each individual derives a benefit.

Mycorrhiza (plural mycorrhizae, mycorrhizal fungi) - species of fungi that form symbiotic relationships with plant roots.

Niche -- the occupied position of a species or population within a site relative to other species and populations. Species have physiological and biotic limitations that restrict where they can disperse (dispersal niche), germinate (establishment niche), grow (adult niche), reproduce (reproductive niche) or persist (expressed niche).

Nitrogen-fixing (bacteria) - the genera of bacteria that have the ability to fixate atmospheric nitrogen and that form symbiotic relationships with certain plants, thereby supplying them with additional nitrogen.

No-Net-Loss -- a national mitigation policy goal to prevent and offset the destruction or degradation of wetlands by compensatory mitigation, creation of artificial wetlands and restoration of and management of existing wetlands.

Nodal - pertaining to the node.

Node - the position on a stem where leaves, buds, and branches originate. See internode.

Nodulation - formation of nodules on plant roots.

Nodules - enlargements or swellings on the roots of plants that are inhabited by nitrogen-fixing bacteria.

Non-dormant refers to seeds that do not exhibit seed dormancy at time of maturity and seed dispersal, and will germinate as soon as they contact moist substrates and ambient temperatures. Same as non-orthodox seeds.

Nurse plant effect -- the mutualistic benefit of the presence of one or more individuals to the germination, growth and survival of another individual(s); reducing physiological stress by reducing evapotranspiration and/or providing physical support. See facilitation.

Nutlet - a small nut; one of the sections of the matured fruit as seen in beebalm (Monarda), self heal (Prunella), alder (Alnus), and birch (Betula).

Open depression - a depressional wetland that is distinguished by having an open basin, larger connection to the surrounding watershed and a connection to groundwater tables.

Organic matter - material of organic origin derived from plants and animals that has decomposed to a state that the contributions are no longer recognizable. When organic matter has broken down into a stable humic substance that resists further decomposition, it is called humus.

Orthodox (seeds) - seeds that exhibit dormancy and can be dry stored for at least 2 years or longer. See dormant (seeds). Compare recalcitrant, suborthodox.

Outplanting - the practice of planting nursery stock onto a restoration site.

Ovary - the expanded basal portion of a pistil that contains the ovules. Following fertilization, ovules become seeds and the ovary becomes the fruit.

Overstory - the uppermost canopy of vegetation in a plant community.

Ovulate - female cones in gymnosperms or female flowers in angiosperms.

Oxidation-reduction potential (soils) - a quantitative measure of the energy of oxidation. Oxidation is equivalent to a net loss of electrons by the substance being oxidized, and reduction is 
substance being reduced.

Partthecarpy - the natural or artificial development of fruit without sexual fertilization. See parthenogenesis.

Parthenogenesis - the development of an unfertilized egg into a new organism without sexual reproduction.

Peat - soil material consisting of partially decomposed organic matter; found in wetlands such as fens, forest swamps, and bogs in temperate and arctic environments. It is formed by the slow decay of successive layers of aquatic and semiaquatic plants, such as sedges, rushes, wetland grasses, and mosses. One of the principal types of peat is moss peat, derived primarily from sphagnum moss.

Perennial - a plant that lives longer than 3 or more years.

Perfect - with both male and female reproductive structures (stamens and pistils) in the same flower; same as bisexual. Compare imperfect; unisexual.

Pericarp - the wall of a fruit.

Perigynium (plural perigynia) - a scale-like, saclike bract that encloses the pistil (and the seed) in sedges (Carex).

Periodic - inconsistent flowering or fruiting exhibited by a species; usually occurring only once every few years.

Periodicity - the time between heavy seed bearing years in flowering plants.

pH - a measure of the acidity or alkalinity of a water sample, soil sample or solution, where 7 is neutral, $>7$ is more alkaline, and $<7$ is more acidic.

Phenology - the various biological processes that are correlated with the seasons, such as flowering, fruiting, dormancy, bud break, and root and stem elongation.
Phenotype - all characteristics of a plant, as determined by the interaction between genotype and the environment. Compare genotype.

Physical dormancy - refers to seeds with hard, impenetrable seed coats that require scarification or naturally occurring high temperatures to initiate germination.

Physical-physiological dormancy - a type of double dormancy seen in species with hard seed coats that also exhibit physiological dormancy. See physical dormancy, physiological dormancy.

Physiological dormancy - a type of internal seed dormancy usually caused by naturally occurring inhibitors. Usually, a period of temperature conditions is required to break physiological dormancy. See physical-physiological dormancy and morpho-physiological dormancy.

Physiology (plants) - the functioning of an organism determined by biochemical processes and cellular and tissue structure and processes.

Pistil - the female reproductive structure in a flower that consists of a stigma, style, and ovary.

Pit - the stony endocarp of a cherry seed; seen in bitter cherry, chokecherry, plum, and wild cherry (Prunus).

Plantlet - a small plant arising from a mother plant.

Playa -- a geographically isolated, shallow depressional recharge wetland found in the southern Great Plains region, formed by subsurface material and wind deflation. Similar to closed depressional wetlands in the Prairie Pothole Region.

Pod - a dry dehiscent fruit; usually refers to a legume fruit.

Pole (cutting) - a hardwood stem cutting that is usually $3.6-4.8 \mathrm{~m}(12-16 \mathrm{ft})$ long and is planted directly on the outplanting site without further treatment. 
Pollination - the transfer of pollen to the stigma (receptive surface on the pistil).

Pothole - a depressional wetland that is distinguished by occurring in depressions carved out by glaciers; closed basins that receive irregular inputs of water from the surroundings and export water as groundwater. Hydrology of potholes is complex and the concentration of dissolved solids results in water that ranges from fresh to extremely saline, with chemical characteristics varying seasonally and annually.

Precocious - flowers emerging before leaves.

Pre-soaking (seeds) - the practice of soaking seeds in running water to imbibe seeds prior to sowing.

Propagule - any plant part (seeds, stems, roots, bulbs, fragments, or turions) that forms a new plant.

Prostrate - refers to the plant habit of growing flat on the ground; not matted or upright.

Radicle - the embryonic root.

Ramet - independent member of a clone.

Recalcitrant - non-orthodox seeds; seeds that cannot be dried and stored, are relatively short lived and germinate immediately after dispersal from the mother plant. See non-dormant. Compare orthodox, sub-orthodox, and dormant.

Recruitment limitation -- describes abiotic factors such as geographic position and distance and biotic factors such as dispersal distance that limits a species ability to recruit into another area. Same as dispersal barrier.

Redox concentrations - soft masses of accumulated iron and manganese concentrations found in wetland soils.

Redox depletions - characteristic in hydric soils that show where reduction occurs, usually in the form of gleying.
Refugia - areas that have escaped recent or past climatic change and serve as a haven for flora and fauna

Rhizomatous - producing or having rhizomes.

Rhizome - a specialized stem in which the main axis of the plant grows horizontally or vertically at or below the soil surface; can be either thickened or very slender, woody or non-woody.

Riparian - the plant community that occurs on the banks of a river or stream.

Root (cuttings) - cuttings made from roots of woody plants during the dormant season that are cut into individual pieces, consisting of dormant shoot buds that are capable of developing into new plants.

Root collar - the top of the root system just below the base of the stem.

Rooting hormone - refers to hormones that stimulate root formation when applied to the base of a cutting usually consist of auxins. See IBA.

Rosette - a dense radiating cluster of leaves usually at or near ground level.

Runner - a slender stolon or prostrate stem rooting at the nodes or tip, as seen in strawberry.

Safe site -- microsite capable of supporting germination and establishment of propagules. See niche.

Saline depression - a depressional wetland that is distinguished by having high salinity attributed to high evaporation and the accumulation of minerals dissolved in the water. Saline depressions are discharge wetlands, where water high in dissolved salts has moved from the regional groundwater system into the depression. During drawdown, salt encrustations form on the soil surface.

Sapling - a young tree that is generally at least 2 years old and $<10 \mathrm{~cm}$ (4 in) in dbh. 
Satellite - refers to a habitat that occurs in distant proximity to similar habitats; important for the migration or movement of organisms.

Scarification - the method of breaking a hard and impermeable seed coat so that moisture and oxygen can enter the seeds, thus allowing for germination.

Sedimentation -- the deposition of soil particles entering a wetland by wind, water or gravitation erosion, causing filling of wetland basins and often forming a distinct layer over wetland soils.

Seed - a ripened ovule that consists of an embryo, seed coat, and usually nutritive tissue (endosperm in flowering plants).

Seedcoat - the protective covering of the seed.

Seed fall - the time in which most seeds are released from the parent plant.

Seed longevity - the amount of time that a seed can remain viable under natural or artificial (storage) conditions.

Seedlot - a quantity of seeds having uniform quality, collected or produced at a specific location, and collected from a single annual crop.

Seed source - geographical location of the original progenitors from which a seed lot was collected.

Seed storage - retention of seeds under artificial conditions.

Serotinous - flowers emerging after leaves have fully expanded.

Species - a group of individuals that usually breed only with one another and exhibit certain characteristics.

Sphagnum - any species of the large and widely distributed genus Sphagnum, the principal peat constituent in fens and bogs, typically growing in hummocks and floating mats.

Spike - an unbranched, elongated inflorescence where flowers do not have stalks and are borne directly on the main stem of the inflorescence, maturing from the bottom upwards.

Spikelet - the flower cluster of grasses (Poaceae), rushes (Juncaceae), and sedges (Cyperaceae), consisting of one to many flowers subtended by two bracts.

Stamen - the male reproductive organ in flowers, consisting of an anther borne on a slender stalk (filament).

Staminate - having or producing the male gametes, such as the male pollen cones in gymnosperms or male flowers in angiosperms.

Steppe - grassland or prairie.

Stigma - the portion of the pistil that is receptive to pollen.

Stolon - a modified stem that grows horizontally above soil line and produces a mass of stems.

Stratification - the combined use of moisture and temperature to overcome seed dormancy.

Style - the usually narrowed portion of the pistil that connects the stigma to the ovary.

Subalpine - growing in the mountains below treeline but above the montane zone.

Submergent - a plant or vegetation that is completely submerged below the surface of the water.

Sub-orthodox (seeds) - seeds that can be stored under certain conditions for a period of a few months to one year. Compare recalcitrant and orthodox (seeds).

Subspecies - a category in taxonomic hierarchy that is below the species level.

Succession - the gradual process of change in an ecosystem brought about by the progressive replacement of one community by another until a stable climax is established. 
Sucker - an aerial shoot stem originating from the root crown or lateral roots from the root crown.

Symbiotic (organism) - an organism that lives on, or in, the root system of a plant in a mutually beneficial relationship. Refer to Frankia, mycorrhiza, Rhizobium.

Taproot - the main root axis from which smaller root branches arise; a root system with a main root axis and smaller branches. Compare fibrous (roots).

Target Plant -- refers to the best nursery stock type (seedlings, cuttings, seeds) and stock type size suited to the conditions and limitations of the restoration site.

Testa - the outer seed coat.

Texture (soil) - a soil property used to describe the relative proportion of different grain sizes of mineral particles in a soil.

Tiller - a subterranean shoot that is more or less erect. Compare stolon and rhizome.

Tillering - producing tillers.

Turion - a specialized overwintering bud produced by aquatic herbaceous plants that forms roots and new shoots the following growing season.

Understory - the lower levels of canopy of vegetation in a plant community.

Unisexual - a flower with either male or female reproductive parts, but not both. See imperfect (flowers). Compare bisexual and perfect (flowers).

Viability - the capacity of seeds to germinate.

Warm-season - plants whose optimal growth usually occurs at temperatures above $29^{\circ} \mathrm{C}\left(85^{\circ} \mathrm{F}\right)$, and that go dormant after the first hard frost.

Compare cool-season.

Warm temperature requiring - seeds or seedlings needing warm temperatures to germinate and grow. Compare cool temperature requiring.
Wet meadow - an herbaceous wetland characterized by having a water table at or close to the soil surface for most of the year, but typically having mineral soils.

Woody - a plant with persistent above ground woody stem(s). Compare herbaceous.

Year effects -- Interannual variations in the establishment success of vegetation in a restoration project, and are largely due to annual climate or cyclical climate events. 
Appendix B. Plant associations and alliances found in Western Prairie Pothole Region wetland ecological systems 


\section{Great Plains Prairie Pothole}

- Distichlis spicata Herbaceous Vegetation

- Hordeum jubatum Herbaceous Vegetation

- Deschampsia cespitosa Herbaceous Vegetation

- Juncus balticus Herbaceous Vegetation

- Salicornia rubra Herbaceous Vegetation

- Schoenoplectus maritimus Herbaceous Vegetation

- Deschampsia cespitosa Herbaceous Vegetation

- Hordeum jubatum Herbaceous Vegetation

- Juncus balticus Herbaceous Vegetation

- Pascopyrum smithii - Hordeum jubatum Herbaceous Vegetation

- Hordeum jubatum Herbaceous Vegetation

- Juncus balticus Herbaceous Vegetation

- Pascopyrum smithii - Hordeum jubatum Herbaceous Vegetation

- Hordeum jubatum Herbaceous Vegetation

- Juncus balticus Herbaceous Vegetation

- Eleocharis palustris Herbaceous Vegetation

- Bromus inermis Semi-natural Herbaceous Vegetation

- Schoenoplectus maritimus Semipermanently Flooded Herbaceous Alliance

- Schoenoplectus acutus - (Schoenoplectus tabernaemontani) Semipermanently Flooded Herbaceous Alliance

- Pascopyrum smithii - Hordeum jubatum Herbaceous Vegetation

\section{Intermountain Basin Greasewood Flat}

- Atriplex confertifolia Shrubland Alliance

- Distichlis spicata Intermittently Flooded Herbaceous Alliance

- Eleocharis palustris Seasonally Flooded Herbaceous Alliance

- Ericameria nauseosa Shrubland Alliance

- Leymus cinereus Herbaceous Alliance

- Leymus cinereus Intermittently Flooded Herbaceous Alliance

- Puccinellia nuttalliana Intermittently Flooded Herbaceous Alliance

- Salicornia rubra Seasonally Flooded Herbaceous Alliance

- Sarcobatus vermiculatus Intermittently Flooded Shrub Herbaceous Alliance

- Sarcobatus vermiculatus Intermittently Flooded Shrubland Alliance

- Sarcobatus vermiculatus Intermittently Flooded Sparsely Vegetated Alliance

- Sarcobatus vermiculatus Shrubland Alliance

- Sporobolus airoides Herbaceous Alliance 
- Sarcobatus vermiculatus Shrubland Alliance

- Sporobolus airoides Herbaceous Alliance

- Sporobolus airoides Intermittently Flooded Herbaceous Alliance

- Puccinellia nuttalliana Herbaceous Vegetation

\section{North American Arid West Emergent Marsh}

- Distichlis spicata Intermittently Flooded Herbaceous Alliance

- Spartina pectinata Temporarily Flooded Herbaceous Alliance

- Juncus balticus Seasonally Flooded Herbaceous Alliance

- Phalaris arundinacea Seasonally Flooded Herbaceous Alliance

- Calamagrostis canadensis Seasonally Flooded Herbaceous Alliance

- Carex (rostrata, utriculata) Seasonally Flooded Herbaceous Alliance

- Carex nebrascensis Seasonally Flooded Herbaceous Alliance

- Carex praegracilis Seasonally Flooded Herbaceous Alliance

- Phragmites australis Semipermanently Flooded Herbaceous Alliance

- Schoenoplectus pungens Semipermanently Flooded Herbaceous Alliance

- Typha (angustifolia, latifolia) - (Schoenoplectus spp.) Semipermanently Flooded Herbaceous Alliance

- Schoenoplectus maritimus Semipermanently Flooded Herbaceous Alliance

- Glyceria borealis Semipermanently Flooded Herbaceous Alliance

- Lemna spp. Permanently Flooded Herbaceous Alliance

- Potamogeton diversifolius, Stuckenia filiformis Permanently Flooded Herbaceous Alliance

- Salicornia rubra Seasonally Flooded Herbaceous Alliance

- Nymphea odorata-Nuphar spp. Permanently Flooded Herbaceous Alliance

- Carex vesicaria Seasonally Flooded Herbaceous Alliance

- Carex utriculata Herbaceous Vegetation

- Salix exigua Temporarily Flooded Shrubland

- Schoenoplectus acutus - (Schoenoplectus tabernaemontani) Semipermanently Flooded Herbaceous Alliance

\section{Northwestern Great Plains Riparian}

- Hordeum jubatum Herbaceous Vegetation

- Salix exigua Temporarily Flooded Shrubland

- Poa pratensis Semi-natural Herbaceous Alliance

- Pascopyrum smithii - Hordeum jubatum Herbaceous Vegetation

- Populus deltoides Temporarily Flooded Woodland Alliance 
- Juncus balticus Herbaceous Vegetation

- Artemisia cana Temporarily Flooded Shrubland Alliance

- Populus deltoides Temporarily Flooded Forest Alliance

\section{Rocky Mountain Alpine-Montane Wet Meadow}

- Pascopyrum smithii - Hordeum jubatum Herbaceous Vegetation

- Hordeum jubatum Herbaceous Vegetation

- Senecio triangularis - Mimulus guttatus Herbaceous Vegetation

- Calamagrostis canadensis Western Herbaceous Vegetation

- Camassia quamash Wet Prairie Herbaceous Vegetation

- Deschampsia cespitosa Herbaceous Vegetation

\section{Rocky Mountain Lower Montane Riparian Woodland and Shrubland}

- Salix bebbiana Shrubland

- Phalaris arundinacea Western Herbaceous Vegetation

\section{Rocky Mountain Subalpine-Montane Riparian Shrublands}

- Salix bebbiana Shrubland

\section{Western Great Plains Closed Depression Wetland}

- Pascopyrum smithii - Hordeum jubatum Herbaceous Vegetation

- Hordeum jubatum Herbaceous Vegetation

- Carex nebrascensis Seasonally Flooded Herbaceous Alliance

- Eleocharis palustris Herbaceous Vegetation

- Hordeum jubatum Herbaceous Vegetation

- Schoenoplectus acutus Herbaceous Vegetation

- Distichlis spicata Herbaceous Vegetation

\section{Western Great Plains Open Depression Freshwater Wetland}

- Carex nebrascensis Seasonally Flooded Herbaceous Alliance

- Carex pellita Seasonally Flooded Herbaceous Alliance

- Schoenoplectus acutus Herbaceous Vegetation

- Pascopyrum smithii - Hordeum jubatum Herbaceous Vegetation

- Carex spp.-Plantago eriopoda Temporarily Flooded Herbaceous Alliance

- Potamogeton richardsonii Permanently Flooded Herbaceous Alliance

- Polygonum spp. Seasonally flooded Herbaceous Alliance

- Polygonum spp. - Echinochloa spp. Temporarily Flooded Herbaceous Alliance 
- Sagittaria latifolia Semipermanently Flooded Herbaceous Alliance

- Potamogeton spp. - Ceratophyllum spp. - Elodea spp. Permanently Flooded Herbaceous Alliance

- Schoenoplectus acutus - (Schoenoplectus tabernaemontani) Semipermanently Flooded Herbaceous Alliance

- Scolochloa festucacea Seasonally Flooded Herbaceous Alliance

- Spartina pectinata Temporarily Flooded Herbaceous Alliance

- Typha (angustifolia, latifolia) - (Schoenoplectus spp.) Semipermanently Flooded Herbaceous Alliance

- Typha spp. - (Schoenoplectus spp., Juncus spp.) Seasonally Flooded Herbaceous Alliance

- Pascopyrum smithii - Hordeum jubatum Herbaceous Vegetation

- Phalaris arundinacea Western Herbaceous Vegetation

- Juncus balticus Herbaceous Vegetation

- Carex praegracilis Herbaceous Vegetation

- Ranunculus aquatilis Herbaceous Vegetation

- Hordeum jubatum Herbaceous Vegetation

\section{Western Great Plains Saline Depression Wetland}

- Distichlis spicata Herbaceous Vegetation

- Eleocharis palustris Herbaceous Vegetation

- Hordeum jubatum Herbaceous Vegetation

- Puccinellia nuttalliana Herbaceous Vegetation

- Carex praegracilis Herbaceous Vegetation

- Galium boreale-unoffical

- Sarcobatus vermiculatus Shrubland

- Salicornia rubra Herbaceous Vegetation

- Sporobolus airoides Herbaceous Alliance

- Distichlis spicata Intermittently Flooded Herbaceous Alliance

- Puccinellia nuttalliana Intermittently Flooded Herbaceous Alliance

- Distichlis spicata - (Hordeum jubatum) Temporarily Flooded Herbaceous Alliance

- Spartina pectinata Temporarily Flooded Herbaceous Alliance

- Pascopyrum smithii Temporarily Flooded Herbaceous Alliance

- Hordeum jubatum Temporarily Flooded Herbaceous Alliance

- Scolochloa festucacea Seasonally Flooded Herbaceous Alliance

- Schoenoplectus pungens Semipermanently Flooded Herbaceous Alliance

- Typha (angustifolia, latifolia) - (Schoenoplectus spp.) Semipermanently Flooded Herbaceous Alliance

- Schoenoplectus maritimus Semipermanently Flooded Herbaceous Alliance

- Sarcobatus vermiculatus Intermittently Flooded Shrub Herbaceous Alliance

- Stuckenia pectinata Permanently Flooded Herbaceous Alliance 
- Puccinellia nuttalliana Herbaceous Vegetation

\section{Northwestern Great Plains Floodplain System}

- Carex nebrascensis Seasonally Flooded Herbaceous Alliance

- Cornus sericea Temporarily Flooded Shrubland Alliance

- Fraxinus pennsylvanica - (Ulmus americana) Temporarily Flooded Forest Alliance

- Populus deltoides Temporarily Flooded Forest Alliance

- Populus deltoides Temporarily Flooded Woodland Alliance

- Salix (exigua, interior) Temporarily Flooded Shrubland Alliance

- Salix planifolia Seasonally Flooded Shrubland Alliance

- Sand Flats Temporarily Flooded Sparsely Vegetated Alliance

- Spartina pectinata Temporarily Flooded Herbaceous Alliance

- Symphoricarpos occidentalis Temporarily Flooded Shrubland Alliance

- Typha (angustifolia, latifolia) - (Schoenoplectus spp.) Semipermanently Flooded Herbaceous Alliance

- Typha spp. - (Schoenoplectus spp., Juncus spp.) Seasonally Flooded Herbaceous Alliance

\section{Rocky Mountain Subalpine-Montane Fen}

- Carex utriculata Herbaceous Vegetation

- Carex lasiocarpa Herbaceous Vegetation

- Carex limosa Herbaceous Vegetation

- Carex simulata Herbaceous Vegetation

- Carex utriculata Perched Wetland Herbaceous Vegetation

- Betula nana / Carex spp. Shrubland

- Salix candida / Carex utriculata Shrubland

- Betula nana Seasonally Flooded Shrubland Alliance

- Carex (rostrata, utriculata) Seasonally Flooded Herbaceous Alliance

- Carex aquatilis Seasonally Flooded Herbaceous Alliance

- Carex buxbaumii Seasonally Flooded Herbaceous Alliance

- Carex lasiocarpa Seasonally Flooded Herbaceous Alliance

- Carex limosa Seasonally Flooded Herbaceous Alliance

- Carex simulata Saturated Herbaceous Alliance

- Salix candida Seasonally Flooded Alliance 
Appendix C. Scoring procedure for calculating stressor impact 
Appendix C. Scoring procedure for calculating stressor impact ratings (sensu Faber-Langendoen et al. 2011).

Table 1. Stressor impact ratings calculations.

\begin{tabular}{|llllllll|}
\hline \multicolumn{1}{|c}{} & & \multicolumn{7}{c|}{ Scope } \\
\hline \multirow{3}{*}{ Severity } & Pervasive & Large & Restricted & Moderate & Small & Nil \\
& Extreme & Very High & High & Medium & Medium & Low & Low \\
& Serious & High & High & Medium & Medium & Low & Low \\
& Moderate & Medium & Medi- & Low & Low & Low & Low \\
& Slight & Low & Low & Low & Low & Low & Low \\
\hline
\end{tabular}

Table 2. Stressor impact rating numerical conversions.

\begin{tabular}{|c|c|c|c|c|c|c|c|}
\hline & & & & Scope & & & \\
\hline \multirow{5}{*}{ Severity } & & 5 & 4 & 3 & 2 & 1 & $\mathbf{0}$ \\
\hline & 4 & 20 & 16 & 12 & 8 & 4 & 0 \\
\hline & 3 & 15 & 12 & 9 & 6 & 3 & 0 \\
\hline & 2 & 10 & 8 & 6 & 4 & 2 & 0 \\
\hline & 1 & 5 & 4 & 3 & 2 & 1 & 0 \\
\hline
\end{tabular}

Table 3. Roll-up procedure for calculating an overall stressor impact rating.

\begin{tabular}{|c|c|}
\hline Impact Values of Stressor Categories & Overall Stressor Rating \\
\hline 1 or more Very High Stressors, OR 2 or more High, OR 1 & \\
\hline High +2 or more Medium & Very High (1) \\
\hline $\begin{array}{l}1 \text { High Stressor, OR } 3 \text { or more Medium, OR } 2 \text { Medium }+2 \\
\text { or more Low, OR } 1 \text { Medium, }+3 \text { or more Low }\end{array}$ & High (2) \\
\hline 1 Medium Stressor +5 or more Low, OR 8 or more Low & Medium (3) \\
\hline 1 Medium Stressor + 1-4 Low, OR 1-7 Low Stressors & Low (4) \\
\hline 0 Stressors & Absent $(0)$ \\
\hline
\end{tabular}


Appendix D. Terminology, description, and calculation of the floristic quality assessment metrics. 


\begin{tabular}{|c|c|c|}
\hline \multicolumn{3}{|c|}{$\begin{array}{l}\text { Appendix D. Terminology, description, and calculation of the floristic quality assessment met- } \\
\text { rics. } \\
N_{n}=\text { count of native species, } N_{a}=\text { count of all species, } N_{e}=\text { count of non-native species, } C_{i}=\text { index of conservatism } \\
\text { for the } i^{\text {th }} \text { species, } x_{i}=\text { percent cover for the } i^{\text {th }} \text { species. }\end{array}$} \\
\hline Indices & Description & Calculation \\
\hline Species richness & Number of plant species observed & $N_{a}$ \\
\hline $\begin{array}{l}\text { Native species } \\
\text { richness }\end{array}$ & Number of native plant species observed & $N_{n}$ \\
\hline $\begin{array}{l}\text { Non-native spe- } \\
\text { cies richness }\end{array}$ & Number of non-native plants & $\overline{N_{e}}$ \\
\hline $\begin{array}{l}\text { Percent non- } \\
\text { native species }\end{array}$ & $\begin{array}{l}\text { Number of native plants divided by the number of } \\
\text { all plants multiplied by } 100\end{array}$ & a) (100) \\
\hline Mean C & Average $\mathrm{C}$-value of all plants & \\
\hline Mean $\mathrm{C}_{\text {nat }}$ & Average C-value of only the native plants & \\
\hline $\begin{array}{l}\text { Cover-weighted } \\
\text { Mean C }\end{array}$ & $\begin{array}{l}\text { Sum of each species C-value multiplied by its cover } \\
\text { values, then divided by the sum of cover values for } \\
\text { all species }\end{array}$ & $\sum_{i=1}^{n} \lambda$ \\
\hline $\begin{array}{l}\text { Cover-weighted } \\
\text { Mean } \mathrm{C}_{\text {nat }}\end{array}$ & $\begin{array}{l}\text { Sum of each native species C-value multiplied by } \\
\text { its cover values, then divided by the sum of cover } \\
\text { values for native species } \\
\end{array}$ & $\sum_{i=1}^{n} \lambda$ \\
\hline FQI & $\begin{array}{l}\text { Mean C of all plants multiplied by the square-root } \\
\text { of number of all plants }\end{array}$ & \\
\hline $\mathrm{FQI}_{\text {nat }}$ & $\begin{array}{l}\text { Mean } C \text { of native plants multiplied by the square- } \\
\text { root of number of native plants }\end{array}$ & $N_{n}$ \\
\hline $\begin{array}{l}\text { Cover-weighted } \\
\text { FQI }\end{array}$ & $\begin{array}{l}\text { Cover-weighted Mean C for all species multiplied } \\
\text { by the square-root of all species }\end{array}$ & \\
\hline $\begin{array}{l}\text { Cover-weighted } \\
\text { FQI }_{\text {nat }}\end{array}$ & $\begin{array}{l}\text { Cover-weighted Mean C for native plants multi- } \\
\text { plied by the square-root of native plants }\end{array}$ & $\left(\sum_{i=1}^{n} x_{i} C_{i} / \sum_{i=1}^{n} x_{i}\right) \sqrt{N_{n}}$ \\
\hline Adjusted FQI & $\begin{array}{l}\text { Mean C of native plants divided by } 10 \text { multiplied } \\
\text { by square-root of native plants divided by the } \\
\text { square-root of number of all plants multiplied by } \\
100\end{array}$ & $\frac{\left.N_{n}\right)}{10} \frac{\sqrt{N_{n}}}{\sqrt{N_{a}}}(100)$ \\
\hline $\begin{array}{l}\text { Adjusted cover- } \\
\text { weighted FQI }\end{array}$ & $\begin{array}{l}\text { Cover-weighted Mean C for native plants divided } \\
\text { by } 10 \text { multiplied by square-root of native plants } \\
\text { divided by the square-root of number of all plants } \\
\text { multiplied by } 100\end{array}$ & $\frac{\left(\sum_{i=1}^{n} x_{i} C_{i} / \sum_{i=1}^{n} x_{i}\right)}{10} \frac{\sqrt{N_{n}}}{\sqrt{N_{a}}}(100)$ \\
\hline
\end{tabular}

